UniVERsidAd NACIONAL DE LA PLATA

FACULTAD DE HUMANIDAdES Y CIENCIAS DE LA EdUCACIÓN

SeCRetaría de Posgrado

\title{
Música y profesión: organizaciones socio musicales y trayectorias emergentes en la ciudad de La Plata (2009-2015)
}

\section{Ornela Alejandra Boix}

Tesis para optar por el grado de Doctor en Ciencias Sociales

Director Dr. Pablo Semán, IDAES-UNSAM

La Plata, 16 de febrero de 2016 


\section{INDICE}

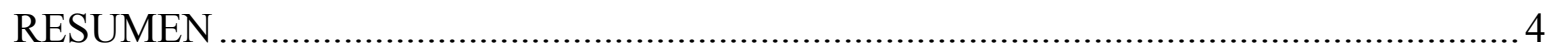

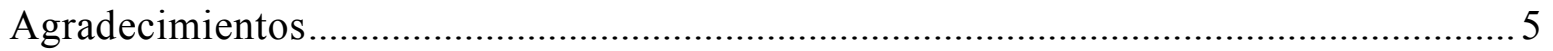

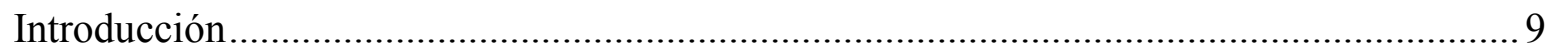

Capítulo I: Lo emergente no es lo dado: etnografía, mediaciones, historia ...................... 19

Encuentro con Concepto Cero .................................................................................. 26

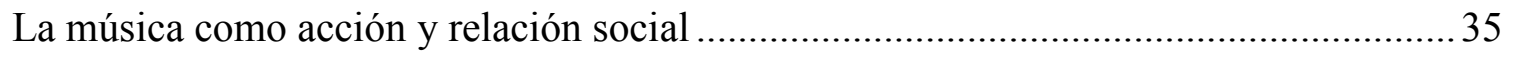

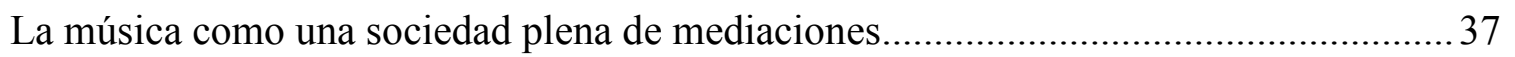

La música como habilitación de una pluralidad de usos .......................................... 43

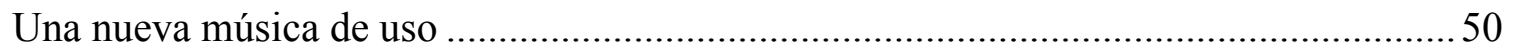

La etnografía desde las mediaciones de una historia.............................................5 52

Capítulo II: Concepto Cero como sello musical gestionado entre amigos........................ 62

“La misma anécdota contada por un montón de gente diferente que es siempre igual.... 63

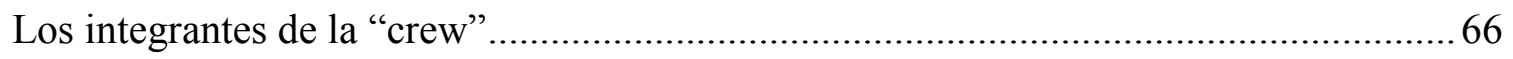

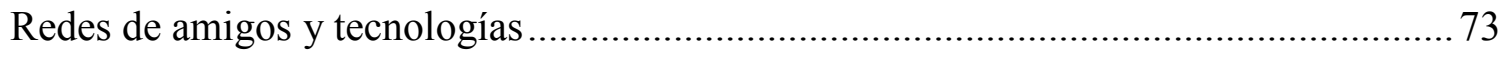

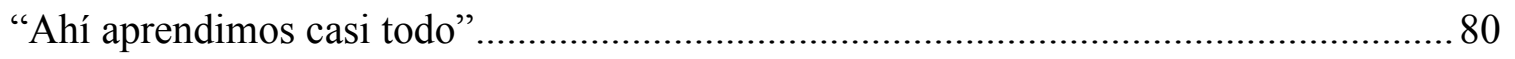

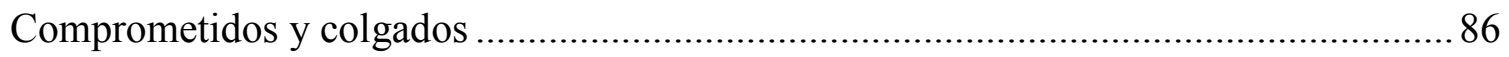

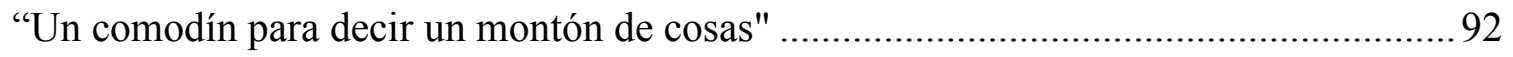

Capítulo III: Entre amigos, hostigadores y aliados: el trazado de redes con otros actores de

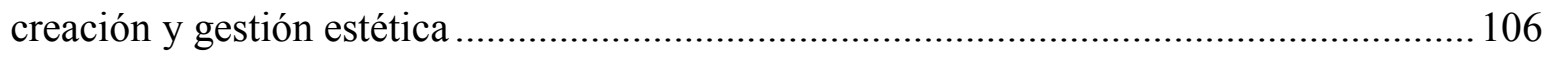

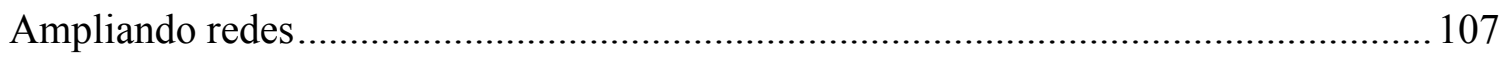

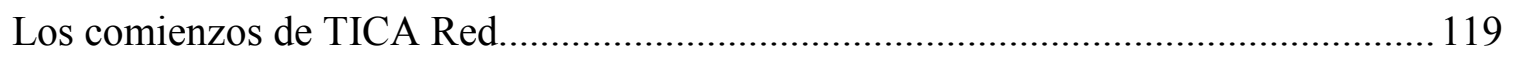

Una interlocución platense para el programa Recalculando ..................................... 126

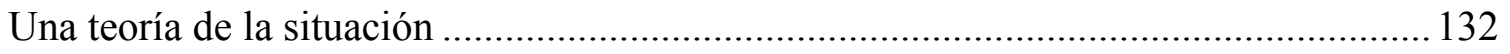

La desactivación de TICA Red......................................................................... 139 


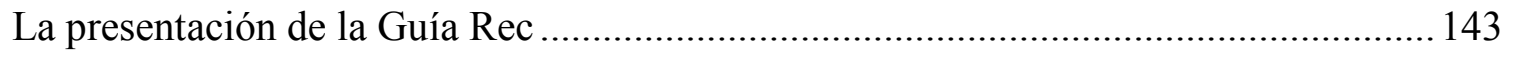

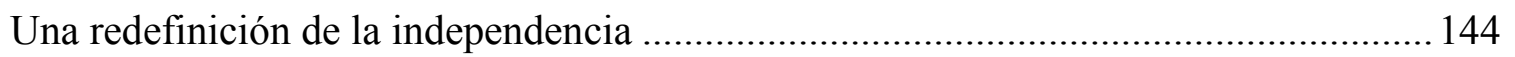

Capítulo IV: Una música que se profesionaliza .................................................... 150

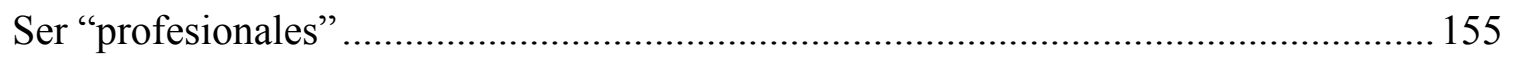

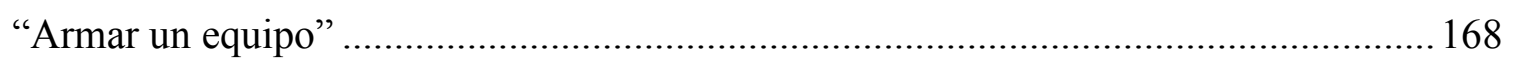

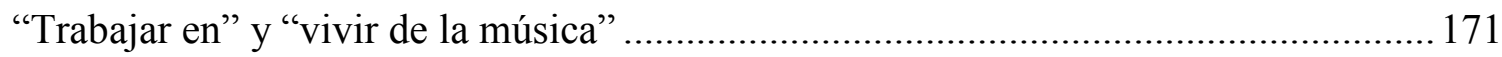

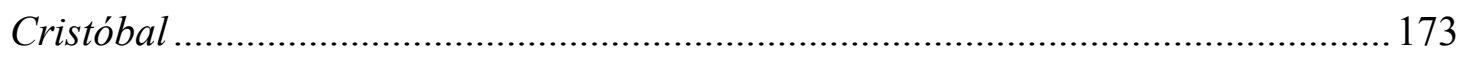

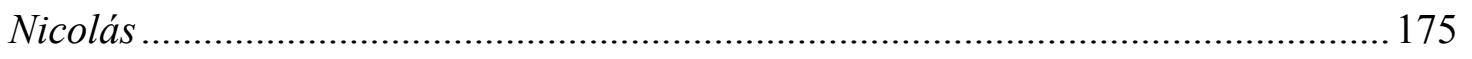

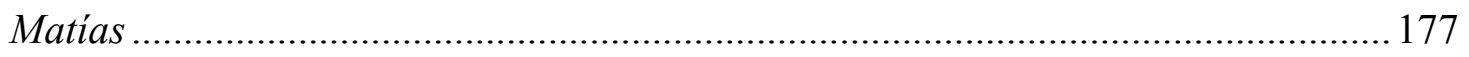

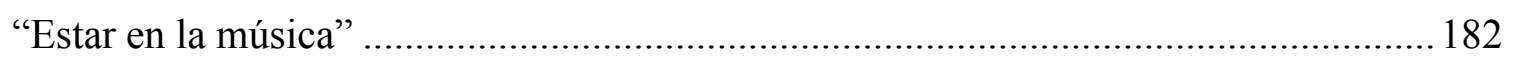

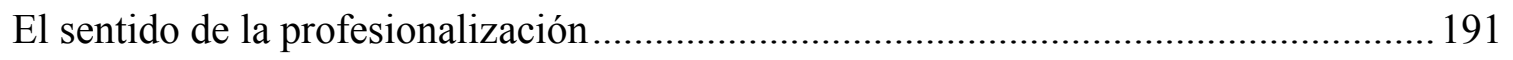

Capítulo V: Un relato para Concepto Cero .................................................................. 194

La escucha como práctica profesional..................................................................... 195

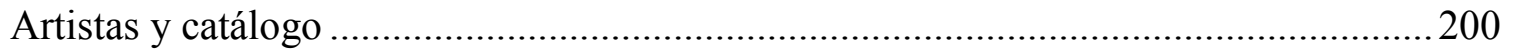

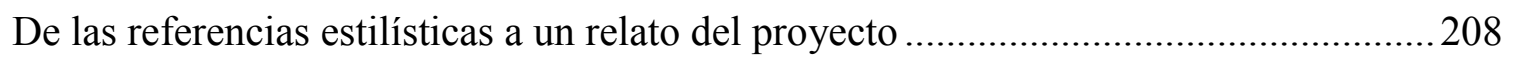

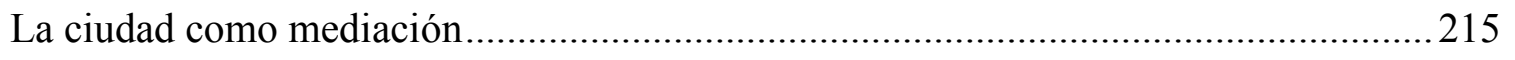

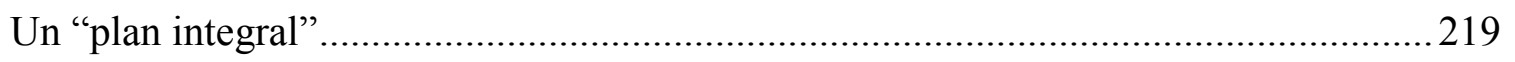

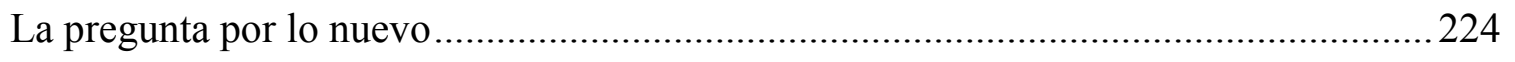

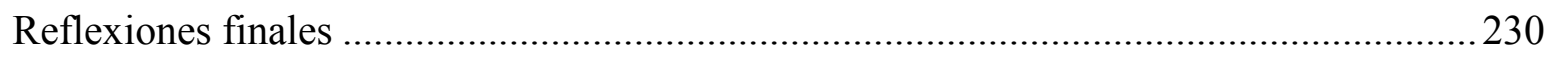

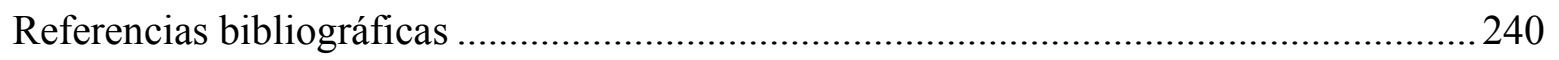




\section{RESUMEN}

Esta tesis se propone describir y analizar en su singularidad una configuración de producción y gestión de música durante el período 2011/2015 en un sello musical de la ciudad de La Plata, integrado por jóvenes músicos y artistas que se visualizan como una nueva generación en el arte. En particular, se indaga en el problema de la profesionalización de dicha organización y de las trayectorias de sus integrantes, en un contexto donde las premisas mismas que suponen la profesión, sus diversas posibilidades y sus tensiones con la vocación, manifiestan, a partir del agenciamiento tecnológico, un proceso de redefinición al interior de los mundos musicales. Con este objetivo, se llevó a cabo un tipo específico de abordaje etnográfico que conjuga una sociología de las mediaciones, el diálogo con los actores (considerados interlocutores) y la centralidad de la narración. Se desarrolla así la historia de un proceso singular de puesta en marcha y profesionalización de estructuras organizativas y trayectos en la música que conjugan de una manera específica el placer con el trabajo, el arte con el comercio y el profesionalismo con la creatividad. La tesis no se propone generalizar desde un caso, sino partir de la singularidad del fenómeno estudiado para dialogar con los estudios sociales de la música, a fin de plantear comparaciones e interrogantes que refinen el conocimiento al interior del campo de estudios y en sus relaciones con la teoría social más general.

PALABRAS CLAVE: Música, profesión, juventud, mediación musical, etnografía. 


\section{Agradecimientos}

Mientras escribía esta tesis, me prometí no dejar la sección de los agradecimientos para el final del proceso. Temía caer en alguno de los peores riesgos del género: la cursilería y el olvido. Ahora, a pocas horas de la entrega, apunto estas líneas. Sólo espero no olvidar a nadie.

Quiero agradecer en primer lugar a mis interlocutores en Concepto Cero, TICA Red y la escena emergente de la ciudad de La Plata. Es un lugar común, pero sin ellos esta tesis no existiría. Agradezco especialmente a Nicolás Madoery y Matías Olmedo de Concepto Cero quienes en 2011 me permitieron empezar una etnografía entre sus amigos, sus conocidos, sus casas y sus reuniones. A Cristóbal Cadierno, Ángel del Re, Damián Anache, Emanuel Orezzo, Valentino Tettamanti, Juan Artero y todos quienes pasaron por Concepto Cero. Nicolás fue extremadamente generoso con esta investigación y me presentó entre otras personas a Martín Mena, a quien agradezco por compartir conmigo Recalculando. Ángel leyó mi tesis de maestría y me hizo comentarios. También a los chicos de otros sellos musicales de La Plata que de repente se encontraron en las redes de esta investigación, especialmente a Lucio Maselli, Diego Montoya, Lautaro Barceló y Juan Gaimaro que conversaron muchas veces conmigo sobre sus vínculos con la música. En su libro Para hablar de la sociedad, Howard Becker dice al respecto de las diversas prácticas para captar y darle sentido a lo social que "Si es divertido, seguro vale la pena". Siempre estoy de acuerdo con cualquier cosa que Becker ponga en un libro pero a juzgar por esta experiencia de investigación estoy aún más de acuerdo.

A Pablo Semán, el director de esta tesis, lo conocí en el año 2006 cuando cursaba el tercer año de la carrera de Sociología de la Facultad de Humanidades y Ciencias de la Educación (FaHCE) de la UNLP. Con mi grupo de trabajo nos habíamos metido en una iglesia pentecostal del barrio de Los Hornos a hacer observación participante para llevar adelante la investigación que nos proponían desde Metodología de la Investigación Social II, una materia troncal de la carrera. Nuestro profesor, Rodolfo Iuliano, nos recomendó escribirle a Pablo, quien no sólo contestó nuestro mail sino que nos invitó a una conferencia en la Biblioteca Nacional de la cual era expositor. Cuando terminó la charla, nos acercamos a Pablo, quien luego de cambiarse tras bambalinas los zapatos por unas zapatillas y 
exclamar contrariado por su incomodidad, fue a tomar un café con leche con nosotros y nos dio muchísimas ideas para el trabajo final de la cursada. Esta es mi tercera tesis (esperemos que la última) en la que la dirección está a cargo de él. Si traigo a colación este primer encuentro, que recuerdo perfectamente, es porque resume el tipo de vínculo apasionado que Pablo tiene con las ciencias sociales, su manera de compartirlo y, en definitiva, la aventura que implica trabajar con él.

El camino de los agradecimientos conduce entonces a Rodolfo Iuliano, quien primero fuera el profesor que todos queríamos y, más adelante, un amigo y un guía en el mundo académico. Fito es una de las personas de las que más aprendí en la universidad: a investigar, a enseñar a investigar y, para decirlo ampliamente, a transitar los pasillos. Fue el co-director de mi tesina de licenciatura y de mi tesis de maestría y continuó su presencia en esta tesis con consejos y lecturas.

Mis amigos Martín Castilla, Nicolás Welschinger y Andrés Stefoni me acompañaron en la larga escolarización de todos estos años. $\mathrm{Y}$ en proyectos de investigación, de becas, de lectura, de escritura, de congresos, de viajes, entre otras cosas que no vienen al caso. Han leído partes de esta tesis y me han escuchado hablar una y otra vez del tema. Con Martín y Nicolás nos pasamos un enero/febrero crítico sentados delante de la computadora y preguntándonos todos los días: “¿Cómo venís?”.

Jerónimo Pinedo fue evaluador de mi tesina de licenciatura $\mathrm{y}$ de mi tesis de maestría. Le agradezco por un lector inteligente y generoso conmigo. Jero, junto a Fito, me invitó a formar parte del equipo docente del seminario de Estudios Culturales de la Maestría en Ciencias Sociales de la FaHCE, donde tengo el placer de dar clases con los materiales que más me gustan.

La presentación de mi tesis de maestría en el año 2013 fue una instancia importante para plasmar parte de lo que venía trabajando desde el año 2011. Carolina Spataro y Marita Carozzi fueron las otras integrantes del jurado que hicieron una lectura comprometida y productiva del texto. Asimismo, parte de la investigación de esta tesis se realizó mientras escribíamos un libro con Guadalupe Gallo y Victoria Irisarri sobre escenas musicales y modos de vida, compilado por Guadalupe y Pablo Semán. Este diálogo es absolutamente central para la forma en que elaboré esta tesis. Por el lado de la etnografía sucede algo similar: en el año 2015, Pablo me invitó participar de un curso centrado en el método 
etnográfico junto a él y Cecilia Ferraudi en la FaHCE. Mi concepción de la etnografía debe muchísimo a los debates que tuvimos entre nosotros, los estudiantes y los investigadores que vinieron a contarnos cómo habían hecho sus etnografías. Especialmente debo agradecerle a Cecilia por haber presentado allí su libro "Ni punteros ni piqueteros", inspirador para narrar mi propia experiencia etnográfica. Por último, con Fito organizamos la visita a la Argentina de Antoine Hennion y el curso que dictó con Pablo Semán en el Doctorado en Ciencias Sociales: "Sociología de los objetos estéticos y las mediaciones", iniciativa que generosamente la FaHCE apoyó y cuyos desarrollos son centrales para la perspectiva de esta tesis.

Pero la historia de mi relación con una sociología empírica de la cultura comenzó en la carrera de grado. El espacio institucional en el que me apropié de los primeros elementos para estudiar los objetos culturales fue el seminario/taller de Sociología y Literatura abierto por Juan Piovani en la carrera de Sociología. Fui alumna de esa materia y luego adscripta por varios años, claramente más de los legalmente permitidos. A partir de ese momento, tengo que agradecer que Juan me haya acompañado en mi trayectoria académica de muchas maneras, entre ellas como co-director de mis becas de doctorado y responsable de proyectos de investigación que no sólo refinaron mi concepción de las metodologías de las ciencias sociales sino que me permitieron investigar de forma descontracturada.

La carrera de sociología y su continuación por otros medios me fue cruzando con compañeras que leyeron mis trabajos con entusiasmo y me ayudaron en este camino: Julia Hang, Soledad Balerdi, Paula Cuestas, Magdalena Lemus. En otra carrera de sociología, la de la UBA, Gabriel Nardacchione me invitó a ampliar la interlocución de esta investigación.

Pude realizar esta tesis gracias a dos becas internas de doctorado de CONICET. Radiqué mi beca en el CIMeCS, centro del IdIHCS, donde me encontré no sólo con jornadas metodológicas, una hermosa biblioteca y otras instancias de formación académica, sino también con un estupendo clima laboral, consejos, conversaciones catárticas necesarias para todo becario e innumerables almuerzos, meriendas y cenas. Agradezco a las autoridades del CIMeCS como a todos mis compañeros. Especialmente a Florencia Bravo Almonacid -gurú de todas las burocracias existentes-, Gustavo Robles -guía turístico 
inigualable- y José Buschini - un editor profesional escondido tras la fachada de un sociólogo brillante.

En la Maestría y Doctorado en Ciencias Sociales de la FaHCE realicé mi formación de posgrado. Varios profesores me ayudaron a formular mi investigación: en particular, José Garriga, Ramiro Segura y Patricia Vargas. Quiero destacar también el compromiso de los docentes del seminario y talleres de tesis de doctorado: Mariana Busso, Sebastián Benítez Larghi, Angela Oyhandi, Matías Iucci y Leticia Muñiz Terra, quienes junto a los compañeros que comentaron mis avances, me orientaron en la formulación de un proyecto y me hicieron imaginar una tesis posible. En el marco del Taller de Tesis II, a cargo de Leticia, se realizó la pre-defensa de esta tesis. El comentarista de los borradores de los tres primeros capítulos fue Sergio Pujol a quien agradezco su lectura atenta, especialmente sobre la formulación y el recorte del objeto.

Párrafo aparte merecen el coordinador de la Maestría y Doctorado Martín Retamozzo, junto a la gestión de Catalina Curciarello, y en el último tramo Luis Santarsiero. Mucha paciencia y dedicación de su parte hacen también posible esta tesis.

Mis otros amigos, la mayoría de los cuales no se dedican a "la academia" y a quienes últimamente no veo demasiado "por culpa de la tesis": gracias a Celeste Sangiao, Libertad Jorquera, Ailin Moreno, Federico Naspleda, Bernarda Andornino, Walter Defrick, Camila Mayorga, Lina Jacovkis, Mariela Radicioni, Josefina Lamenza, Mercedes Albo, Laura Pedro, Claudia Pantoja por acompañar este proceso. A mis amigos de Twitter, Amadeo Gandolfo y Fernando Folino que leyeron la tesis de maestría, me prestaron libros y se coparon con mis preguntas.

Gracias también a Nicolás Rinaldi, "el doctor del Skype”.

A mis padres Carlos Boix y Patricia Bermani, por todo lo que hicieron con la boca cerrada, y que me permitió dedicarme a estudiar e investigar, como recuerdo que quise desde chica. A mi hermana Florencia que me acompaña en ese deseo.

Esta tesis es un regalo a Nicolás Carlino, mi mayor esfuerzo de despliegue de una música en la que nos conocimos y nos encontramos todos los días. 


\section{Introducción}

A mediados del mes julio del año 2014, Nicolás me escribió por el chat de la red social Facebook para invitarme a la "firma de contratos" del sello musical Concepto Cero que tendría lugar el sábado siguiente en unas oficinas de co-working que había alquilado para ese evento en pleno centro de la ciudad de La Plata. Nicolás era el responsable del sello, a veces también se declaraba su "director", y desde el 2011 -año de inicio de mi trabajo etnográfico con el sello- me invitaba a todos los eventos producidos bajo su rótulo. Al llegar ese sábado a la tarde, encontré en la puerta del lugar a Feldman ${ }^{1}$, uno de los periodistas que estaba trabajando con $\operatorname{Shaman}^{2}$ en la gestión de las redes sociales de su último proyecto: Shaman y Los Pilares de la Creación. Mientras tocábamos timbre, lo vimos venir a Anache ${ }^{3}$ con dos botellas de Coca Cola grandes en sus manos. Anache estaba por lanzar su disco solista desde Concepto Cero, además de que cooperaba con actividades de gestión para el sello desde el año 2012.

Subimos los tres por una escalera angosta hacia el espacio de oficinas. Arriba, nos encontramos con distintas habitaciones recicladas que habían pertenecido a una antigua casa de paredes gruesas, techos altos y pisos de madera. Algunas de las paredes, pintadas de blanco al igual que todas las que componían la oficina, estaban adornadas con carteles de películas como Amélie y Cinema Paradiso. Otras vestían vinilos con nubes de palabras: impacto, creatividad, comunidad, desafío, conocimiento, eran algunas de ellas. Cuando entramos a la sala que nos correspondía, nos esperaban Nicolás y Juan, otro miembro del sello, músico y periodista; Germán, otro de los chicos que trabajaba con Shaman; Manuel, un fotógrafo de la escena contratado para cubrir el evento y, finalmente Teo, un amigo de todos ellos que tenía bandas en la escena desde por lo menos el año 2004 y había sacado su último material por Dice Discos, un sello musical amigo de Concepto Cero. Mientras servíamos las gaseosas en vasitos de telgopor, Nicolás me preguntó si alguna vez había

\footnotetext{
${ }^{1}$ Lo llamaban por su apellido.

${ }^{2}$ Shaman Herrera es un cantante, músico, compositor y productor nacido en la Patagonia pero que ha desarrollado la mayor parte de su trayectoria artística en la ciudad de La Plata. Entre sus proyectos, figura el extinto Shaman y los Hombres en Llamas, editado por Discos Laptra. En el período etnográfico condujo Shaman y los Pilares de la Creación, cuyos discos - como se verá en el V- fueron producidos por Daniel Melero y editados por Concepto Cero.

${ }^{3}$ Damián Anache, a quien mis interlocutores siempre llamaron por su apellido.
} 
visitado estas oficinas y le contesté que no. Me contó que además de alquilar oficinas, el espacio organizaba ciclos de cine y otros eventos culturales.

Una placa de plástico en la pared indicaba que estábamos en la "sala de reuniones". Además de la habitación principal, teníamos a nuestra disposición un cuarto pequeño, que Juan utilizaría luego para grabar una mini entrevista en video de cada banda o solista que firmaría contratos esa tarde: Sr. Tomate, Damián Anache, Shaman y Los Pilares de la Creación, Excursiones Polares. Mientras esperábamos que vinieran el resto de los músicos, conversé unos minutos con Anache quien enseguida me dijo "me presenté para ser compañero tuyo en CONICET”. Hablamos un poco de la presentación a la beca aunque él no se imaginaba con posibilidades: a su juicio, la mayor parte de sus antecedentes artísticos no serían bien puntuados.

Poco a poco, fueron llegando el resto de los músicos: Shaman y sus compañeros de los Pilares; Poli, la cantante de Sr. Tomate, banda que compartía músicos con Shaman; finalmente, los Polares, que habían viajado desde su centro de operaciones en Quilmes. Shaman estaba entusiasmado porque ese mismo día le habían entregado la edición final del que sería su próximo video clip y nos lo mostró en la Macbook de Nicolás desde la página de la red social Vimeo en la que el video estaba alojado en modo privado. Shaman, Feldman y Germán relataron entre risas sus aventuras en la filmación, por ejemplo para captar en imágenes a "unos bambis", como dijo Feldman, que se cruzaron en el camino inhóspito por el que transitaban en camioneta. A todos les gustó el video y Poli lo felicitó a Shaman con unas palmaditas en la espalda y una frase: "está muy bueno, parece una película". Mientras tanto, en un costado, Nicolás y Juan se deshacían en elogios sobre el fotógrafo en términos de su práctica no entrometida y prácticamente invisible. Nicolás decía: "Es profesional, profesional, realmente así tiene que ser un fotógrafo".

Cuando ya todos los músicos habían llegado, nos sentamos alrededor de la mesa redonda y Nicolás habló para todos, mientras Manuel no paraba de disparar el obturador. Dijo que más allá del "acting” de juntarse para hacer las firmas, el sello "va a manejar sus obras... es una confianza grosa". Dijo que Concepto Cero se estaba acercando a una "línea editorial", a diferencia de "cierta cuestión ecléctica" que identificaba con años anteriores. Ahora todos los proyectos participaban de una "unidad estética", donde la canción -"pero desde otro lugar de ver la canción"- era importante. Al cabo de estas palabras, abrió la 
ronda de comentarios para las distintas bandas. Mientras tomábamos Coca Cola y otras gaseosas, Ángel y Roy, de Excursiones Polares, contaron que pensaban sacar un nuevo disco, y Anache se explayó sobre su álbum de "música generativa" que saldría semanas después en co-edición con un sello de la Ciudad Autónoma de Buenos Aires (CABA). Germán declaró que estaba tratando de ayudar en "los Pilares" a "profesionalizarse dentro de nuestro alcance", a la vez que a encontrar una "identidad visual" para la banda.

Luego llegó el turno de Shaman, cuyo proyecto era una de las últimas incorporaciones de Concepto Cero. Shaman expresó que "desde que trabajamos con Nicolás se generó un orden", a la vez que había conseguido establecer "rutinas laborales". Planteó una diferencia con su situación anterior en la que "siempre produje todo yo" y enumeró distintas actividades como componer, tocar, hacer la promoción, vender las entradas. Ahora, por el contrario, había armado un grupo de trabajo con Mati, Ger y Teo, además de trabajar con Nicolás y otros integrantes del sello. Según sus palabras, luego de varios años de tránsito en la escena había caído en la cuenta de lo que implicaba "vender un show" y, en general, de todo lo que la música exigía a nivel organizativo. "Excels hay que hacer un montón", sintetizó, y todos nos reímos. En este sentido, afirmó que Concepto Cero era una "tercera vía" que suponía "tener un porcentaje empresarial". Lo diferenció de otras situaciones: "En la antigüedad, uno firmaba con un sello y se olvidaba", a lo que Nicolás rápidamente acotó: "Me da gracia que digas en la antigüedad... porque hoy sigue pasando." Shaman le dio la razón y presentó la otra situación frente a la cual Concepto Cero era un tercer camino: "La otra es 'yo soy mi propio sello' ...". El resto asentía con la mirada.

Habilitado por las palabras de Shaman, Nicolás clarificó lo que esperaban lograr como sello: ni "un sueño mainstream" ni "quedarse tocando en Pura Vida...", un pequeño y conocido bar de la ciudad en el que solían presentarse la mayoría de las bandas de la escena a la que estos músicos pertenecían ${ }^{4}$. Claro que enseguida Nicolás aclaró "no por Pura Vida", ya que con su dueño tenían una excelente relación. A continuación, Ángel

\footnotetext{
${ }^{4}$ Ubicado en la diagonal 78 entre 8 y 61, a pocos metros de la Facultad de Bellas Artes, su fachada es la de una casa antigua, y se emplaza frente a una plazoleta graffiteada donde bancos de madera tipo deck soportan diariamente a una gran cantidad de jóvenes que comparten comidas, toman cerveza, organizan festivales contra alguna política gubernamental y/o universitaria, reparten folletos, venden discos pirateados, fuman porro o pasan el tiempo, a casi cualquier hora. El bar abre generalmente de jueves a domingo, y tiene una programación exclusiva de bandas "independientes" de estilos diversos que se cuidan de no combinar en una misma velada. Es un lugar oscuro y caluroso con una decoración sobria, para muchos un "antro". Dado que no había que "pagar para tocar" (volveré sobre ello en el capítulo II), el bar Pura Vida se erigía en el espacio favorito de la escena emergente de la ciudad.
} 
recuperó las primeras palabras de Shaman para expresar: "Ordenarse es primordial, ordenarse porque por ahora tenés dos o tres horas por día para hacer esto...el resto de las horas estamos laburando". Roy aportó otra apreciación: llegaba un punto en el que el músico no podía hacerlo todo $\mathrm{y}$, en este sentido, el sello aportaba "una mirada más de afuera" que resultaba fundamental. Con respecto a este punto, Ángel compartió el ejemplo de "un amigo guitarrista, súper profesional”, que sacó un disco "para bailar”. Ángel relató cómo este amigo había invertido muchísimo dinero en la producción discográfica, además de pagarle a un "prensero" para terminar presentando el álbum en un lugar que tenía sillas. Ángel concluyó: "No se te puede pasar eso... pero la cuestión es que se te pasa".

Luego de que se sucedieran otras conversaciones en un clima muy distendido, Nicolás hizo un gesto con las manos que remitía a la acción de firmar y Shaman respondió sobreactuando seriedad: "¿Quieren que procedamos?... Fumamos un faso". Todos estallamos en risas. El primero que firmó fue Shaman (por Shaman y Los Pilares de la Creación); lo siguió Anache; en tercer lugar, Poli (por Sr. Tomate) y, finalmente Roy (por Excursiones Polares). Antes de firmar, Roy, Ángel y sus compañeros de los Polares se la pasaron bromeando. Roy afirmaba estar esperando un llamado del responsable del sello porteño Estamos Felices, considerado pionero en el ambiente. Uno de sus amigos de banda le hizo una joda y le llamó con el celular simulando que era de Geiser, un sello de Pop Art considerado por estos músicos a la manera de una suerte de mainstream de la escena emergente $^{5}$. Mientras el fotógrafo retrataba la firma de Roy, Shaman se sumaba a las bromas. Se imaginaba en un tiempo futuro y simulaba su pena frente al momento que vivíamos: "esa fue la peor decisión que tomé en mi vida".

Al término de las firmas, la reunión se dispersó en conversaciones protagonizadas por pequeños grupos. Con Nicolás hablamos de las firmas que restaban realizar porque los artistas estaban de gira. Luego llegó Roy y le preguntó a qué hora él calculaba que tendrían que llegar para probar sonido al "Senado", haciendo referencia a un ciclo que el grupo de

\footnotetext{
${ }^{5}$ Mainstream, anglicismo usado para referir a los gustos y preferencias mayoritarias, asociadas a los grandes medios masivos. Por lo general, esta distinción implica un contraste moral, donde lo independiente es siempre creativo, puro y democrático frente a lo pretendidamente estandarizado, corrompido y oligárquico. Sin embargo, la oposición mainstream / independiente adquiere valencias específicas en los distintos casos empíricos. Esta asociación de Geiser con el mainstream se aprecia en este pequeño relato: en el año 2014, un músico de una banda en ascenso de la escena me contó que Pop Art les estaba escribiendo. Le pregunté si era para distribuir el disco y me aclaró que no, que estimaban que querían "ofrecerles algo en Geiser". Finalmente me comenta que "no vale mucho la pena porque todas las cosas que agarra Pop Art se vuelven una mierda".
} 
Nicolás, Juan y otros miembros del sello organizaban para una dirección cultural del Estado de la provincia de Buenos Aires. Entonces, Ángel se acercó para comentarme que había leído mi tesis de maestría -sobre los sellos musicales emergentes de la ciudad de La Platay que tenía algunos comentarios para hacerme. Estimaba que me podían ser de utilidad para la tesis de doctorado. Hablamos un tanto sobre su lectura y me desafió: “¿Qué te parece esto como fin de la tesis de doctorado, un sello independiente firmando contratos?" Le contesté que justamente había estado pensando en ello cuando firmaban y me permití compartirle una proyección: "Cuando escriba el libro de Concepto Cero, este momento va a ser crucial". Nicolás replicó: "Con todo lo que viniste, espero que sí, que saques un libro".

En la tesis de maestría que había presentado en el 2013, año anterior a esta escena etnográfica, había estudiado en la ciudad de La Plata el mundo de la denominada música indie y sus flexibles fronteras de sensibilidad, a partir de una investigación realizada entre los años 2009 y 2011. Si bien mi objetivo inicial había sido interpretar el indie en tanto estilo estético, la propia dinámica del objeto me condujo a prestarle atención al marco de acción que esos músicos identificados con el indie compartían con otros de su generación, quienes elegían otras palabras para referir a su música. De esta manera, la tesis avanzaba en el análisis de modos y dinámicas de producción musical entre los jóvenes que se hallaban en un momento de emergencia y se sintetizaban, en parte, en una organización social productora de música que denominé "sello", siguiendo la convención propia de los músicos con los que había realizado el recorrido. En esos años (2009/2011), la preocupación por la profesionalización no era central entre ellos. En los casi cinco años de trabajo etnográfico con Concepto Cero, los elementos de la configuración musical emergente que analicé en mi tesis de maestría evolucionaron, evidenciando al mismo tiempo un cambio en la situación histórica en la cual estas prácticas musicales tenían lugar. De forma contemporánea a mi etnografía, se redefinían -a pasos agigantados a través de una agencia tecnológicamente habilitada- las posibilidades de producción y gestión de la música y, por lo tanto, las premisas mismas que suponen la profesión y sus diversas posibilidades.

No hace demasiados años, en un trabajo originalmente publicado en el año 2001, Simon Frith (2006: 54) podía plantear que en el contexto de la música popular no resultaba fácil trazar una línea que separe con nitidez lo profesional de lo amateur. A continuación, ejemplificaba con el caso de los integrantes de un grupo que tocan con asiduidad en un 
club, quienes pueden descubrirse un día, súbitamente, firmando un contrato con una compañía, bien pagados por hacer prácticamente lo mismo que han hecho durante años en calidad de aficionados. De acuerdo a su lectura, lo que mediaba entre las instancias profesional y amateur era un contrato discográfico. En su crítica a la arbitrariedad de esta distinción al interior de la industria de la música popular, no coincidente siempre con la calidad de la performance, Frith devuelve una imagen precisa de la relación más o menos necesaria que el carácter profesional de un proyecto musical guardaba con los mecanismos de la industria discográfica.

La firma de contratos que relaté en las páginas anteriores tenía lugar en mi cuarto año de trabajo etnográfico con un sello musical que había surgido seis años atrás y que en su avance en la escena había reclutado a un conjunto de artistas. El contrato no iniciaba ninguna relación: el evento acontecía luego de otras reuniones y conversaciones en las cuales se había discutido la conveniencia de realizar contratos a fin de ordenar las relaciones entre el sello y las bandas. Es más: lo que he llamado "los artistas" y "el sello" no eran dos entidades perfectamente separadas puesto que varios de los músicos involucrados participaban desde hacía años y de manera más o menos comprometida de la gestión del propio sello con el que firmaban. Aún cuando Nicolás era su “director”, no era un mánager ni un pequeño ejecutivo, se reconocía como músico y originalmente había iniciado el emprendimiento junto a unos amigos para auto-editarse. Por otra parte, en comparación con la imagen típica que devuelve la industria discográfica, estos contratos se firmaban entre pares y hasta cuatro años después de un trabajo conjunto.

Para mi tesis de maestría, había llegado a describir a los sellos de La Plata como instituciones claves de la escena emergente. En los sellos se materializaba una sociabilidad estética, se sostenían proyectos musicales que excedían la edición de discos y se ampliaban las participaciones posibles de los sujetos en la música. En relación con este último punto, había observado la centralidad que, en comparación con generaciones de músicos anteriores, adquiría la gestión de su propia música. Shaman, Ángel y Roy lo manifestaban con claridad durante aquella tarde de fotos y firmas: en el interior del sello, cada músico no estaba a cargo de todas las actividades necesarias para llevar adelante su proyecto pero tampoco, parafraseando a Shaman, podía simplemente firmar y olvidarse. Acompañar a Concepto Cero me permitió singularizar las observaciones de mi tesis de maestría acerca de 
la forma de instituir el sello musical y regular las actividades de los músicos y artistas que lo integran, a la vez que descubrir los procesos por los que un sello se transformaba y esas tareas se volvían trabajo y profesión para los artistas.

La escena de la firma de contratos estaba informada por otra: la que denuncia una y otra vez, y sin dudas con razón, la desventaja típica del músico en la época del imperio de las grandes discográficas. Tal como puede interpretarse en las bromas de los integrantes de Excursiones Polares y especialmente en la actuación de Shaman de un futuro en el que se arrepentía del contrato que ahora firmaba, todos conocían ese modelo de carrera profesional que el comentario de Frith sintetiza. En este modelo la firma de contratos era el momento en que unos músicos tocados por la varita mágica - por una misteriosa combinación de talento, azar y modelo de negocio- podían llegar a grabar su disco y participar de las grandes ligas. En sus versiones críticas, la que mis interlocutores invocaban, esto les hacía perder en el mismo momento su autonomía como artistas, los derechos de sus canciones y las posibles ganancias. Pero nadie entre nosotros interpretaba que la historia se repitiera como farsa: el consentimiento que los músicos ahora estampaban continuaba acuerdos de palabra ya probados y porcentajes de ganancia anteriormente discutidos, como dividir los ingresos bajo la modalidad "50 y 50" en una fecha co-gestionada por el sello y el artista.

¿Por qué para los músicos del sello la firma de contratos era significativa al punto de que Ángel la candidateaba para cerrar el informe de mi investigación? Como en el caso de los músicos de Frith, en el ámbito estricto de la performance musical las firmas no conllevaban ningún cambio. Como evidenciaré a lo largo de esta tesis, para Nicolás, Anache, Ángel y otros miembros de Concepto Cero que protagonizarán las páginas siguientes, la firma de contratos, más allá de sus componentes de "acting”, significaba dar un paso más, tanto en una transformación del sello que contemplaba lo "empresarial", como diría Shaman, como en la composición por parte de sus integrantes de un vínculo profesional con la música. En esta búsqueda de "profesionalizarse dentro de nuestro alcance", la firma de los contratos volvía a confirmar para ellos que la profesión musical podía plantearse con relativa autonomía de la gran industria.

Una vez producida esta desvinculación entre la profesión y la industria musical, ya no se puede dar por sentado que la categoría de lo profesional tenga un significado unívoco. Esta crisis en lo que se identifica como profesión en la música puede observarse en una 
bibliografía tensionada entre el reconocimiento de prácticas profesionales en los términos de la industria musical tradicional o bien desde parámetros que aún resulta difícil determinar. De la misma manera, sería reduccionista suponer que la profesionalización remite a un proceso general bajo el que puedan subsumirse (o medirse) una variedad de experiencias musicales. A pesar de que las nociones de lo amateur y lo profesional suelen concebirse como un par dicotómico con el que podría clasificarse la totalidad de la música, son dos términos relacionales relativos a la configuración musical singular que se tome en consideración. En este sentido, el objetivo de la tesis es desplegar las múltiples mediaciones involucradas en esa relación, a partir de los resultados obtenidos en un trabajo etnográfico centrado en el sello musical Concepto Cero, que fue realizado entre los años 2011 y 2015.

La escena con la que comencé esta tesis adelanta, aunque para nada agota, algunas de las mediaciones que hay que desplegar para hacer emerger esta forma singular de producir y gestionar la música de forma profesional. En primer lugar, mi foco en la organización social productora de música que protagoniza este proceso: el sello musical. Como ya señalé, llegué a Concepto Cero luego de un tránsito de investigación en la escena indie y emergente de La Plata entre los años 2009 y 2011 donde había conocido a otros sellos y colectivos musicales similares. Estos eran motorizados por jóvenes universitarios con quienes compartía espacios de ocio, gustos musicales e incluso referencias escolares. En el capítulo I, expondré los puntos salientes de aquella primera investigación con respecto a la manera en que me orientaron a realizar una etnografía dilatada en un sello musical. Esta decisión, junto a la forma en que ciertas perspectivas teóricas sobre los fenómenos musicales se conjugaron con las exigencias de la etnografía como método, me llevaron a re-construir el objeto sello musical al que ya me había aproximado en la tesis de maestría.

La firma de contratos con la que comencé esta tesis, como otros de los numerosos encuentros que recuperaré a lo largo de los capítulos, era una reunión profesional pero también una oportunidad para estar con amigos. Germán, Feldman y Shaman contaban los avatares de una filmación como una verdadera aventura, y más tarde los integrantes de Excursiones Polares bromeaban entre sí. Pero el sentido de su amistad iba más allá de la simpatía para convertirse en un lazo específico, distinto de la intimidad emocional, que 
permitía sostener los proyectos musicales y, en general, la expectativa de unas trayectorias orientadas a "vivir de la música". Como amigo, Germán ayudaba a la profesionalización del proyecto de Shaman. ¿Qué significaba esta amistad? ¿Qué compromisos suponía ser amigos en este contexto etnográfico? ¿Cómo los amigos producían en el sello musical? En el capítulo II me extenderé sobre el punto de partida de la etnografía y del proceso de profesionalización: el sello Concepto Cero en tanto red orientada a la producción y gestión de música entre amigos y tecnologías.

Entre los participantes de Concepto Cero la producción y gestión de la música no aspiraba al "sueño mainstream", como decía Nicolás, pero tampoco a tocar para los mismos amigos de siempre. Entre ambas instancias, se podía desplegar una propuesta entre el compromiso artístico y la voluntad de obtener recursos y profesionalizarse. Así, sostener el proyecto exigía establecer conexiones con otros actores. ¿Cuáles eran los criterios para tender estas redes? ¿De qué manera el concepto de red se volvía central para estos músicos? En el capítulo III desarrollaré un proceso de establecimiento de redes de Concepto Cero con otros sellos, colectivos y proyectos estéticos, políticas públicas y funcionarios estatales, organizadores de eventos y empresas. En estas redes, el Estado y las ciencias sociales eran partes constitutivas, por lo que exploro estas coincidencias, en un contexto en el que la creatividad se ha convertido en clave tanto de la política pública en el área de cultura como de las interrogaciones académicas.

En tanto acontecimiento, el encuentro de firmas remitía a la posición específica del sello en el mundo musical emergente. Como relaté, los compañeros de banda de Roy lo llamaban por teléfono en una escenificación del supuesto interés de sellos con más trayectoria, reconocimiento, y/o recursos. ¿Cuál era la especificidad del modelo de sello que Concepto Cero proponía en relación con sus pares de la escena?¿¿ ¿Qué sentido adquiría la referencia al carácter empresarial entre sus redes? Al interior de Concepto Cero, ¿qué responsabilidades había que tomar para "ser profesionales"?, ¿cómo la música se “ordenaba" y se constituía en un trabajo?, ¿qué lugar en la organización tenían los músicos que devenían "responsables" o gestores de las obras de los demás? ¿Qué significaba, en definitiva, ser profesionales de la música? En el capítulo IV describo y pondero un punto de llegada del proceso de profesionalización de Concepto Cero en tanto sello musical 
emergente, en el que ya se delinean unas específicas trayectorias profesionales entre los músicos que permanecen en el sello.

Por último, en el encuentro mencionado al inicio Germán indicaba que con Shaman y los Pilares de la Creación se encontraban en la búsqueda de una "identidad visual", al tiempo que Anache establecía la especificidad de la música que hacía y luego Nicolás invocaba una "identidad estética" que congregara a todos los proyectos de Concepto Cero y los hiciera dejar atrás el eclecticismo característico de los inicios del emprendimiento. ¿Por qué la identidad estética no se había efectivizado en el transcurso del período etnográfico? ¿Bajo qué premisas estos diferentes artistas habían llegado a compartir un sello? ¿Qué suponía el establecimiento de una "línea editorial”? En el capítulo V presento un proceso en el que los músicos toman en consideración diferentes señas de la identidad con el objetivo de definir su sello y la propia categoría de música profesional. Finalmente, en las conclusiones retomo las líneas de análisis para explicitar los hallazgos y el diálogo etnográfico en el que intenté construir una teoría de una música singular. 


\section{Capítulo I: Lo emergente no es lo dado: etnografía, mediaciones, historia}

En mayo de 2015, cuando ya consideraba prácticamente terminado mi trabajo de campo con Concepto Cero ${ }^{6}$ y comenzaba mis intentos en la escritura de esta tesis, me encontré en una parada de colectivo céntrica a Lucio, estudiante de arquitectura, músico y "agitador" de Dice Discos, uno de los tantos sellos musicales de la ciudad de La Plata que conocí en el año 2012 a partir de mi trabajo etnográfico con Concepto Cero. Uno de sus compañeros de sello me había recomendado enfáticamente entrevistarlo: "Lucio se la pasa 'agitando' y poniéndole 'pilas' al proyecto”. Seguí este consejo y en el año 2013 mantuve con él una entrevista. A partir de entonces, siempre que nos cruzamos conversamos un largo rato, especialmente en recitales de las bandas de Dice Discos, como Un Planeta, Joyaz, Camión, Fabricio Algo o Bautista Viajando.

Ese día del encuentro callejero, luego de actualizarme sobre las cuatro materias que le quedaban para recibirse y de evaluar al respecto: "Estoy demorando [tiene 29 años y ya trabaja de arquitecto a pesar de no haber finalizado la carrera] porque no quiero recibirme... porque lo que yo quiero es dedicarme a la música", comenzamos a hablar de los sellos de La Plata. No era la primera vez: Lucio sabe de mi tesis y se interesa por hablar de ello conmigo. Me cuenta que está un poco alejado de la escena por estos finales que le faltan y por una obra en la que empezó a trabajar como arquitecto en la Ciudad Autónoma de Buenos Aires (CABA). “Quiénes están ahora?”, me pregunta. Comienzo a intentar responder pero él rápidamente enumera: "Concepto Cero, Dice..., Laptra, Unclan, Algo increíble". Conozco a todos y a varios de primera mano, menos a Algo increíble, de quién ni siquiera oí nombrar. A Concepto Cero porque llevo cuatro años de trabajo etnográfico con ellos. A Laptra porque, entre fines del año 2009 y principios del año 2011, realicé observaciones sistemáticas en los recitales de sus bandas y entrevisté a algunos de sus miembros, además de seguir cruzándome con ellos en los eventos asociados a la escena. A Dice Discos porque desde el año 2012 mantengo amistades con algunos de sus grupos, especialmente con Un Planeta. Le pregunto a Lucio por Algo increíble y me contesta: "Son

\footnotetext{
${ }^{6}$ Aunque asistía varios eventos que implicaban al sello y sus integrantes luego de esa fecha.
} 
Reimon y esos...pero ese es un sellito..." y mientras lo dice hace un gesto con las manos, como si sellara algún objeto con un sello de goma.

Conocí a Reimon ${ }^{7}$ el mismo día que asistí a mi primer recital en La Plata: corría el año 2005 y con una amiga fuimos al Centro Cultural Favero a escuchar a Sr. Tomate. Tal como yo, mi amiga era del "interior": nos habíamos conocido en la convivencia de una pensión estudiantil en las inmediaciones de la Facultad de Bellas Artes de la Universidad Nacional de La Plata. Ella conocía a Reimon y antes del recital por algún motivo fuimos a su casa. Como él era amigo de los miembros de la banda y nosotras bastante descaradas, no pagamos entrada. Con el dinero que me pasaban mis padres compré un EP del grupo "sellado" con el rótulo Cloe Discos. El EP consistía en un CD virgen grabado dentro de un sobre de papel con una ilustración de inspiración japonesa en blanco, negro y rojo. Cloe Discos se disolvió bastantes años antes de que pudiera construir un problema analítico alrededor de mi interés por la acción estética de los sellos musicales de La Plata, pero Sr. Tomate firmó en el año 2014 un contrato con Concepto Cero en una de las tantas escenas que presencié como investigadora y que recreé en el comienzo de esta tesis.

Este interés comenzó a perfilarse como un posible problema de investigación cuatro años después de aquel recital. A mediados del año 2009 comencé a participar de un proyecto colectivo de investigación sobre los usos de la música entre los jóvenes de la zona metropolitana de Buenos Aires ${ }^{8}$. Inicialmente buscábamos las relaciones entre géneros musicales y públicos juveniles, pero el desarrollo, llevado a cabo por distintos miembros del proyecto, de focos etnográficos anclados en espacios donde se escuchaba y bailaban diferentes versiones del rock, la cumbia y la música electrónica, nos llevó a cuestionar la misma pertinencia de la noción de géneros musicales para organizar la recepción musical, a la vez que la heterogeneidad que implicaba la categoría de juventud (Semán 2012). Justamente, comenzaba a revelarse para nosotros la importancia que adquirían las nuevas

\footnotetext{
${ }^{7}$ Reimon fue músico de Círculo de Medianoche, una banda de culto del indie de La Plata. Fundó Cloe Discos a principio de la década del 2000, referido como "uno de los primeros sellos indies y semillero de artistas como El Bicho Bolita, Atmosferia -ahora Chico Ninguno-, y Sr. Tomate - produciendo y grabando sus dos primeros discos". Por otra parte, "además de organizar innumerables eventos y recitales para las bandas de Cloe Discos y de otros sellos independientes de la ciudad, participó como músico y productor de las siguientes bandas: What's up in your mind?, Demencia, Hongo, Elysees, Yagui Quintero, Los Cubiertos, Casiasesino, Paseo Único, etc.”. Citas extraídas de la siguiente página web, consultada el 20/06/2015: http://www.discosindependientes.com/2010/07/artista-reimon.html

${ }^{8}$ Se trataba del proyecto PICT-2006-02186: "Los géneros musicales populares. Producción, circulación y recepción", dirigido por Pablo Semán.
} 
tecnologías en la recomposición del gusto musical -que se pluralizaba e individualizaba- y de la producción -que se diseminaba. (Semán y Vila 2008, Semán, 2011, Gallo 2015, entre otros).

En este contexto, desde septiembre de 2009 desarrollé en la ciudad de La Plata una experiencia etnográfica en los espacios de la "música indie", el cual se constituye hacia comienzos de la década del 2000 en una modulación particular de la música independiente, asociada a la "novedad" de la música juvenil contemporánea, como eventual relevo de formas del rock en ese momento en crisis: el rock chabón y el rock nacional de las grandes bandas. Para comprender su emergencia, hay que considerar un movimiento que se remonta al menos a la década del noventa. En aquellos años el rock nacional asumió, por un lado, un giro hacia el espectáculo con el respectivo ingreso al show business y al gran público (Alabarces et al. 2008), por el otro, desarrolló una vertiente que hoy se podría denominar "populista", tanto por su temática como por su estilo. La prensa especializada y el mundo del rock llamaron a este fenómeno de enraizamiento del rock en los sectores populares -que en ciertos casos también llegaba a llenar estadios- "rock chabón”. Semán (2006) lo definió como un rock nacionalista, bailable y democratizador en la relación entre "productores" y "receptores". Esta sensibilidad, más que un género musical, construía una epopeya con los marginales y contra la represión policial. Frente a ambos fenómenos, y radicalizando el histórico conflicto alternativo/comercial hacia el interior del mundo del rock, se desplegaba una modulación particular que aportaba más a los sentimientos y al glamour, privilegiando el intimismo por sobre lo social (Gallo y Semán 2009): se trataba del llamado rock y pop "alternativo" e incluso indie. Luego de la tragedia de Cromañón y la descalificación del rock chabón -las críticas retrospectivas al género por una "pobreza" estética que lo hacía prácticamente culpable del incendio-, estos modos alternativos adquirieron la posibilidad de hacer valer su propuesta que ya había conformado un radio de acción y una legitimidad propia. De esta forma, en un proceso que no puede ser fechado con exactitud y que prácticamente no ha sido estudiado, el espacio de la música considerada juvenil en la Argentina de la década del 2000 se abrió a una renovación temática y estilística, delineándose un fin de ciclo.

Por entonces, y aún hoy, del indie no muchos pueden asegurar si se trata de un estilo musical, una estética, un régimen de la vestimenta, un halago o una acusación, pero sí que 
se ha convertido en un significante relativamente central en los círculos permeados por sensibilidades estéticas e intelectuales de La Plata. Así, el sentido del término resulta situacional y polémico: cuando se habla de indie muchos suponen una imagen que no coincide con la que imaginan otros, si bien suelen creer que hablan de lo mismo (Boix 2013). En La Plata, la categoría de indie encontraba un sentido y una circulación específicas que definí a partir de las nociones de lo relajado, lo rockero y lo anti-careta (Boix 2011, Boix 2013). Lo relajado, como una forma de relacionarse con la música y de producirla que determinaba un elogio del amateurismo y un minimalismo de la ambición en relación con las perspectivas de carrera. Lo rockero porque, a diferencia de otros mundos indies recuperados por la literatura -por ejemplo para el caso de la CABA, Peña Boerio 2011-, el de La Plata se construye a partir de una prolongación de ciertas actitudes de transgresión atribuidas a la cultura del rock. Esto lo coloca en una disputa por el sentido del rock nacional, diferenciándolos de quienes, identificados también como indies, consideran intrascendente esa batalla. La acusada impronta anti-careta, por su parte, viene a resignificar una noción históricamente presente en las diferentes culturas juveniles, y en particular en los mundos del rock. Sin embargo, lo careta ya no se identifica tanto con "lo comercial", sino con el carácter contracturado y ambicioso, dada la mayor legitimidad que conquista la noción de mercado y su familia semántica en este mundo musical.

En primer momento, el trabajo se había orientado hacia los artistas -los solistas y las bandas- que componían una escena, de acuerdo a los músicos y demás productores estéticos que conocía a lo largo de las observaciones y entrevistas. Mi inserción en este mundo musical estuvo dada por la asistencia a eventos nocturnos, como recitales, fiestas y festivales, que observaba a partir de protocolos tan detallados como genéricos ${ }^{9}$, a la vez que

\footnotetext{
${ }^{9}$ Específicamente, este protocolo de observación elaborado a partir de mi participación en el PICT ya mencionado establecía las siguientes preguntas orientadoras:

"Una primera delimitación del espacio: ¿cuál es la ubicación dentro de la ciudad/localidad del lugar en el que se lleve a cavo el evento? (atender a cuestiones como la relación centro/periferia, los circuitos específicos de la ciudad y el barrio).

¿Cómo se delimita el adentro y el afuera del evento? ¿Cuál es el tamaño de la o las entradas físicas al lugar donde se emplaza el evento? ¿Hay carteles, gigantografías, publicidades?

¿Hay una o varias colas diferenciales para el ingreso? ¿Marcan diferencias o distancias sociales? ¿Cuáles? Otro elemento a observar es la puesta en escena propia del evento: ¿cómo están dispuestas las luces? ¿Cómo se relacionan con la performance musical?

¿Cómo está dispuesto espacialmente el sonido?, ¿baja del escenario o es envolvente y parejo en cuanto a sonido en todo el lugar? ¿Hay escenario? ¿Cómo es? Si no fuera el caso, ¿cómo se indica el lugar de performance en su diferencia con otros lugares?, ¿o bien no hay diferencia?
} 
por el uso de las redes universitarias que compartía con algunos de los músicos. La de los músicos y su escena era una instancia evidente para mí como “joven” socializada en el rock nacional y consumidora de música independiente que se producía en escenas. Por otro lado, la historización de la tradición del rock local tendió a relegar a las instituciones y, en general, dispositivos de mediación musical a un lugar secundario, frente a la importancia otorgada a los artistas -salvo quizás los recitales, por su importancia en nuestro país como espacio de socialización de la juventud en períodos represivos (Vila 1985, Pujol 2007), de transgresión ante el mundo adulto (Citro 2008), de conformación de la subjetividad (Salerno y Silba 2006).

Fue así que mi tesis de licenciatura (Boix 2011) se organizó a partir de la noción de escena. Categoría propia de los grupos analizados, al utilizarse también como categoría del análisis resultó iluminadora y relativamente fácil de trabajar, ya que relacionaba un estilo musical y estético específico con "un contexto cultural urbano y práctico de un código espacial" (Stahl 2004: 76). Esta categoría que relaciona lo local con lo musical resulta muy utilizada en los trabajos que vinculan música y sociedad: así Quiña (2009a 2009b), Vecino (2011) y Gallo y Semán (2012), entre otros, analizan escenas musicales adscriptas a la

¿Quién está en el escenario para el evento que se está desarrollando? ¿Cómo se lo jerarquiza arquitectónicamente? ¿Se lo marca de otras maneras?

¿Cómo juegan estos elementos y otros que encontremos en la elaboración de un "dispositivo"?: ¿de escucha?, ¿de práctica musical?, ¿de baile?, ¿de todo esto y más?

- Tiempo de la fiesta, tiempos de la fiesta:

¿Cómo se desarrolla la previa al show, performance o espectáculo que convoca el evento?

¿Todos los sujetos llegan a la misma hora al evento, entran directamente? ¿Quiénes llegan a qué hora?, ¿pueden diferenciarse grupos a partir de la hora en la que llegan?

¿Qué pasa cuando el espectáculo termina?, ¿la gente se retira?, ¿cómo? ¿El evento sigue en el mismo lugar pero de otra manera?, ¿la fiesta sigue en otros lados?

Desde mi papel de observadora participante, ¿cómo experimento el tiempo en el evento? ¿Se pasa rápido o lento? ¿Hay tiempos más dinámicos y otros más acompasados para mí?

-Actores:

¿Cómo experimentan los asistentes el lugar en el que se realiza el evento? ¿Cómo se experimenta la puesta en escena y/o la escenografía?, ¿cómo interactúan con ella?

¿Se mueven por los alrededores del lugar en el que se llevará a cabo el espectáculo? ¿Lo hacen en grupos o de forma individual?

¿Cómo se ubican las personas y los grupos en el espacio de la fiesta? ¿Se conforman centros y periferias dentro del espacio de la fiesta? ¿Hay juegos de mirar y de ser miradas/os?

¿Cómo interactúan los sujetos con la música?, ¿se producen diálogos corporales con ella?, ¿cómo son esos movimientos y cuándo se dan?

¿Según la ubicación espacial en el evento los espectadores reaccionan de forma diferente ante la música? Tanto en la previa, como en la performance musical propiamente dicha y luego de ella: ¿Qué tipo de interacciones se establecen entre música, o ejecutantes de la música, y públicos? 
CABA; mientras Woodside Woods et al. (2011) hacen lo propio para la escena popular alternativa en la ciudad de México.

Desde la óptica de Becker (2008) y Faulkner y Becker (2011) consideré a la escena emergente de La Plata un mundo negociado de trabajo colaborativo. Me orienté a describir las redes que producían este mundo estético, en sus modos concretos de socialización y la geografía simbólica de sus lugares de encuentro; sus modalidades de consumo musical; sus sentidos morales y estéticos de lo que implica hacer música, en tensión con otras escenas estéticas; sus usos particulares de las tecnologías; entre otras dimensiones que le daban singularidad. Asimismo, la noción permitía no inferir que entre las escenas y la estructura de grupos y relaciones sociales haya una relación fija, unívoca y de homología, como supone el concepto de subcultura ${ }^{10}$.

Como ya fue señalado, en el primer tramo de mi trabajo etnográfico (2009/2011) realicé observaciones sistemáticas en eventos musicales acompañadas de entrevistas a sus músicos y participantes. Poco a poco, en la tarea de "seguir a los actores" (Callon 1986), el protocolo de observación estándar de eventos que había construido se fue particularizando. A medida que construía relaciones etnográficas más consistentes, mi comprensión de la escena indie comenzó a revelarse poco sensible tanto a las distintas redes de afinidad, trabajo artístico y gestión que la cruzaban, como a las conexiones que estas tenían con otras escenas estéticas independientes de La Plata pero también de la zona metropolitana de Buenos Aires. Mientras se volvía metodológicamente necesaria la elección de un contexto más acotado y localizado para realizar un trabajo en mayor profundidad, de acuerdo a las prerrogativas de un tipo de abordaje etnográfico, los sellos musicales aparecían para mí como un enigma.

En mi primer acercamiento a los sellos musicales de la escena de La Plata entrevisté a los músicos de algunos asociados al indie -entre ellos Laptra en La Plata, y Triple RRR en el Conurbano bonaerense- y a productores vinculados a este mundo musical. Interpreté estos emprendimientos que llamaban sello tal como mis interlocutores los definían: "grupos de amigos" que tenían bandas y editaban bajo un mismo rótulo sus discos. El sello era una

\footnotetext{
${ }^{10}$ Como se verá más adelante en este capítulo -apartado: "La música como una pluralidad de usos"-, la tradición subculturalista considera que el estilo pone en escena un sistema de homologías. Sobre la superación de esta posición y una hipótesis sobre la relación entre interpelaciones y narrativas que da lugar a identidades en el uso de la música, ver: Vila 1996.
} 
fuente de identificaciones para esas bandas, sin encargarse de otra cosa que de su reunión y promoción. A la vez, otorgaba inteligibilidad a las interacciones que ocurrían en la escena: los sellos aparecían como formas de referenciar grupos de personas, proyectos musicales, modos de trabajo. En este sentido, la idea dominante entre los músicos con los que traté en aquel período (2009/2011) del sello como un "sellito" que se imprime a los discos resulta sintética de este tipo de conceptualización. Es la idea que refiere Lucio cuando, en el encuentro callejero narrado al inicio, me habla de Algo increíble: sea justo o no, actualiza en el año 2015 una categoría de clasificación de los sellos musicales muy operativa en años anteriores. Es que en la continuidad del trabajo de investigación, varios sellos que podían identificarse con una noción de "sellito" comenzaron a mutar hacia organizaciones de gestión y participación musical más sólidas.

En el transcurso de mi primera inmersión en el tema, los músicos y productores musicales con los que compartía recitales y entrevistas referían al sello meramente como un "paraguas" que les permitía agruparse. Resultaba llamativo, sin embargo, que no dejaran de adscribirse de forma permanente a un sello del que, a la vez, burlaban su importancia, a sabiendas de que distaba bastante de corresponderse con la noción de sello construida por la industria discográfica durante gran parte del siglo XX. La lectura del clásico estudio de Negus (2005) desprende una imagen del sello discográfico como una organización empresarial que fabrica discos para vender en el mercado, para lo cual cuenta con una estructura consolidada de toma de decisiones y una división del trabajo establecida. Esta formulación es válida tanto para las majors $^{11}$ como para las indies ${ }^{12}$ : las compañías compiten entre sí por las cuotas de mercado y la formación de catálogos. De acuerdo a su tamaño, podremos hablar de "sub-sellos" en su interior orientados a distintos géneros musicales o de propuestas de mercado más dirigido -los llamados "nichos". En esta competencia, los sellos discográficos tienen su papel en el encuadramiento y sostén de la creatividad musical en diversas categorías, incluidos los propios géneros musicales.

\footnotetext{
11 La industria discográfica en cada país se divide en majors, las grandes empresas globales, y las independientes -llamadas indies o minors-, que van desde las micro empresas de subsistencia y las PyMEs hasta las grandes empresas nacionales, usualmente pertenecientes a conglomerados mediáticos (Yúdice 2008). Así, las major labels son Universal, Sony-BMG, EMI y Warner Music, multinacionales que se han diversificado hacia otros campos del "entretenimiento".

${ }^{12}$ Aquí la palabra indie refiere a la distinción usual entre compañías disqueras, sentido diferente a los criterios de estilo y moralidad que diferencié páginas atrás en relación con el llamado indie platense.
} 
Los sellos musicales de la escena independiente de La Plata habían re-semantizado este concepto. Aparentemente minimizados por los músicos, sin una sede física pero no por eso virtuales, configurándose en redes y haciendo gala de una "organización desorganizada", lo que llamaban "sello" de todas maneras reunía establemente a un grupo de personas y habilitaba la existencia de proyectos musicales, públicos y trayectorias individuales en la música. ¿Cómo funcionaba y qué representaba el sello musical en este contexto? En la continuidad de mi trabajo de campo con Concepto Cero y con otros sellos que conocí a partir de las redes tendidas por el primero, entre los años 2011 y 2015, pude contestar a esta pregunta, a la vez que reinterpretar los datos que había obtenido en mi anterior trabajo de investigación, entre los años 2009 y 2011. Estas reformulaciones serán trabajadas en el próximo capítulo. A continuación, describiré mi encuentro con la unidad etnográfica de esta tesis: el sello musical Concepto Cero, anclado en la ciudad de La Plata.

\section{Encuentro con Concepto Cero}

En abril del año 2011 comencé a buscar un espacio donde emplazar las observaciones que quería fueran el fundamento de mi investigación de doctorado. Esperaba que el espacio elegido me conectara con músicos jóvenes activamente implicados en la búsqueda no sólo de un mayor reconocimiento artístico sino también de la sustentabilidad económica de sus proyectos. Por inquietud personal, ese mismo mes comencé a tomar clases particulares de guitarra con el líder de una banda de rock independiente de La Plata. Las clases tenían lugar en un centro cultural que él mismo estaba montando junto a un socio con el que dividía los gastos de alquiler y las inversiones de acondicionamiento del sitio. En este lugar se dictaban otros talleres y clases, pero principalmente se organizaban recitales que, luego de haber presentado mi tesina de licenciatura sobre la música indie de La Plata, podía entender como parte de una escena independiente vinculada con el indie, pero no necesariamente inscripta en sus criterios estilísticos y morales. Con el correr de los encuentros, además de practicar notas, escalas y canciones muy simples, hablábamos entretanto de las posibilidades profesionales y económicas en este particular mundo musical. Enterado de mi interés académico en estos temas, mi profesor me invitó a los ensayos de su banda y a fechas de recitales que se realizaban en el centro cultural. También 
me habló del proyecto de sello editorial del centro cultural y me mostró la vitrina de discos que tenían a la venta. Entusiasmada, comencé a realizar registros de estas experiencias y a asistir a los eventos a los cuales era invitada: asistí a algunos ensayos de su banda -en una sala alquilada para tal fin, a unas pocas cuadras del lugar donde estudiaba guitarra- y a varios recitales del centro cultural, además de tomar las clases como un espacio de observación para mi investigación y no sólo de aprendizaje en la técnica de un instrumento.

Por esa misma época continuaba mis intercambios con Nicolás, del sello Concepto Cero, por la red social Twitter, a quien conocía desde el año 2010 por transitar la misma escena. Durante ese año, hacía entrevistas para mi tesina de licenciatura y retomaba elementos de dichas conversaciones en mis tweets. En una manera de estar al tanto de mi trabajo sociológico con las bandas indies, Nicolás solía contestarme con algún que otro tweet. Si bien ni él como músico ni su sello se reconocían como indies en el sentido común en La Plata antes sintetizado, me pareció que entrevistarlo podría servirme de "contraste" y un día a fin del año pasado nos juntamos. Nicolás me recibió la habitación que ocupaba en la casa de su madre con una remera de Warp ${ }^{13}$, un sello independiente inglés. La situación fue la de una entrevista abierta, biográficamente orientada, donde derivamos especialmente por su trayectoria personal en la música. En ese primer encuentro en persona, a fines del año 2010, Nicolás comentó que si bien "todavía estamos preocupándonos por hacer algo que esté bueno", también les interesaba ver "cómo, de alguna forma, se puede vivir de esto". Agregaba "Yo pienso que se puede, pero no sé cómo... De la música no vas a vivir y de una banda menos. Pero hay un montón de cosas alrededor, como puede ser la publicidad, la tele, el cine... que teniendo todo un equipo trabajando...". Al mismo tiempo, a la vez que no ganaba dinero -"todo lo que entra sale"-, expresaba: "Tratamos de trabajar... por más de que esto, que el capital sea todo muy a pulmón, tratamos de trabajar como una empresa". Como había observado en esa entrevista y en las publicaciones del sello que seguía por Facebook, Concepto Cero ya delineaba retóricas de profesionalización y comercialización de la actividad musical no tan presentes hasta el momento en otros colectivos musicales de La Plata, pero que luego comenzaron a generalizarse. De esta manera, la elección del objeto

\footnotetext{
${ }^{13}$ Warp es un sello de música electrónica e indie que comenzó a partir de una idea de tres amigos de la ciudad de Sheffield. A lo largo de su recorrido integró al sello proyectos complementarios de diferente índole como Warp Films y Warpmart, un servicio de venta por correo, mucho antes de que aparezcan las redes P2P.
} 
empírico se realizó en base a criterios de significatividad teórica y no de representatividad empírica.

Su discurso decidido me había extrañado - si bien los demás también hablaban de dinero, no era común escuchar esas perspectivas en las demás entrevistas-, a la vez que me había intrigado en un sentido muy específico: ¿es que realmente un grupo de jóvenes podrían vivir de la música y trabajar como una empresa? Luego de la entrevista nuestra interacción por Twitter continuó. En mayo de 2011 le escribí por ese medio, de manera sucinta, obligada por el máximo de 140 caracteres que permite un mensaje, acerca de una propuesta que relacionaba mi investigación con su sello. Intercambiamos un par de tweets e inmediatamente amplié por mail con la sugerencia de "empezar a seguir la producción de Concepto Cero más de cerca, quizás seguir a alguna de las bandas en particular también". Me contestó que le interesaba pero que debía consultarlo con su "socio", quien hasta ese momento yo ni siquiera conocía. Unos días después se comunicó conmigo por correo electrónico para decirme que "le diéramos para adelante", proponiendo una reunión entre los tres a los fines de pactar cómo sería mi trabajo de campo.

Al llegar uno de esos días al centro cultural me encontré con que mi clase de guitarra se había suspendido. La asociación de mi profesor y su amigo se había disuelto y a partir de ese momento las clases serían en la casa del primero. Razoné que iba a ser bastante costoso acceder al mundo colaborativo de personas que sostenía el proyecto colectivo, cuando este se encontraba atravesado por conflictos que desencadenaban separaciones y cambios de emplazamiento. A su vez, con el correr de las clases noté que mi profesor parecía alejarse del proyecto combinado de centro cultural y sello que a mí me interesaba para dedicarse a la grabación del segundo disco de su banda. Este acontecimiento me señaló, por primera vez, una situación que vería repetirse una y otra vez en mi trabajo de investigación: las dificultades con las que los proyectos colectivos de este tipo se encuentran son muchas y también los movimientos de personas que colaboran en la red, aunque en ese momento mi preocupación se centraba en decidir de una buena vez el emplazamiento de la etnografía. Precisaba focalizar en alguna de estas dos tramas de actores y la balanza se empezaba a inclinar por Concepto Cero. Paradójicamente, esa elección me permitió un año después conocer en otro contexto al ex socio de mi profesor, interpelado por una convocatoria para armar una red de sellos en La Plata y en la provincia 
de Buenos Aires, impulsada entre otros por Concepto Cero, proceso sobre el que me detendré en el capítulo III.

Aún con dudas, el 31 de mayo de 2011 me encontré con Nicolás y Matías, los "socios" de Concepto Cero en aquel momento, para conversar de mi investigación y de mi interés específico en su sello. La reunión fue en la casa de Matías, quien por entonces vivía en un departamento antiguo frente a la terminal de ómnibus de la ciudad de La Plata. En el patio interno que atravesamos para entrar, luego de que Matías me abriera la puerta y yo me presentara, vi varias bicicletas atadas que luego relacioné con sus presumibles dueños: cuatro estudiantes de cine que se encontraban en la primera habitación de la casa, editando videos delante de varias pantallas planas de computadora. Las paredes estaban cubiertas de posters, relativos a recitales, discos y otros productos musicales. En la habitación de Matías funcionaba también su propio estudio de grabación llamado La Pieza y fue allí, entre equipos de sonido, que hablamos. Ellos hacían otras cosas al mismo tiempo. Nicolás, con una MacBook Pro en su falda no paraba de mirar su Twitter y otras páginas, sin dejar de estar absolutamente atento e implicado en nuestra conversación, lo que se repetiría en cada reunión, aunque variaran los dispositivos, durante los casi cinco años del trabajo de campo. Por su parte, Matías seguía el proceso del video que se estaba editando en el living de la casa.

Por mi parte, me presenté como estudiante de posgrado que quería realizar "una investigación sobre la música independiente" y sobre los modos de trabajo y profesión que allí se manifestaban. Expuse para ellos las líneas de lo que yo suponía que sería mi investigación doctoral: les conté que se situaba en el cruce entre nuevas tecnologías, juventud y música, que me interesaba el problema de la profesionalización de las escenas y las trayectorias, que cuestionaba un poco las distinciones clásicas entre lo amateur y lo profesional. Les hice saber también que tenía una beca del CONICET, dato que nunca olvidaron y que les sirvió infinidad de veces para hacer bromas sobre mi supuesta capacidad de financiamiento de sus proyectos musicales. Finalmente, les comuniqué mi intención de "devolver" de alguna manera el tiempo y la atención que ellos me iban a brindar. A este respecto, Nicolás me planteó una posibilidad: podría escribir reviews en el sitio del sello, de eventos o discos, pero que igualmente eso lo tendríamos que ir viendo. En una asociación de esta situación con otras anteriores, enseguida me contaron de dos chicas 
que les habían recomendado para hacer prensa y relaciones públicas, resultando un "fiasco" en términos de trabajo. Las chicas les habían mandado la gacetilla del evento un día antes, lo que a ellos les pareció “cualquiera”. Entonces, con respecto a mi participación en el proyecto, Nicolás volvió a decir: "Tenemos que ir viendo cómo se dan las cosas...claro que ese [el de las chicas] es un caso extremo".

Hablamos luego un rato de la escena musical que los tres referenciamos como "platense", la cual en sí misma problemática resultó útil para referir a una serie de bandas vinculadas con el rock ${ }^{14}$. Les conté que en mi tesina de licenciatura-que había terminado en febrero de ese año- había tomado como objeto a una porción de ese universo, el mundo musical y estético del indie. A ellos les interesó ese trabajo, a la vez que les permitió una primera diferenciación en términos bastante críticos con ese grupo. Matías, por el lado de la composición musical: "Todas las canciones de [una de las bandas por entonces más reconocidas del llamado "indie platense"] son iguales", dijo luego de tararear partes de algunos temas en plan demostración de variaciones de una canción básica. Nicolás, por su parte, riéndose del análisis musical de Matías, planteó que a él le gustaba ese grupo, pero lo que sin duda no entendía era cómo habían logrado llegar a tocar en Europa con una estructura de gestión bastante poco ortodoxa. Yo contesté que ese era también mi interés, a lo que replicaron prácticamente al unísono: "Sí, por favor, explicanos cómo puede ser".

En este sentido, Nicolás y Matías plantearon esa noche criterios de trabajo, y por lo tanto de selección de las bandas y artistas con los cuales relacionarse, bastante diferentes de los que me había acostumbrado el mundo del indie rock de La Plata en un momento específico de su desarrollo (2009-2011), cuando los sellos musicales de la escena tenían estructuras más acotadas. Nicolás decía que a él musicalmente le gustaban muchos artistas, pero un sello debía contemplar también cómo esas personas trabajan y se desenvuelven, tanto arriba como abajo del escenario, especialmente en lo que refiere al manejo, por parte de las bandas, de la comunicación y de las redes sociales. Yo recordaba las bandas indies

\footnotetext{
${ }^{14} \mathrm{Al}$ respecto, Keightley (2006: 155) señala cómo, a nivel global, el término rock resulta "vago hasta la frustración". Este autor plantea que no existe una esencia musical del rock, sino más bien unos contextos históricos específicos -audiencias, discursos, prácticas industriales y comerciales, etc.- que modelan una percepción particular sobre la adscripción de cierto artista al rock. En este marco, la cultura rock se ha definido, históricamente, por sus singulares procesos de exclusión, basados en el rechazo de ciertos aspectos de la música de distribución masiva valorados como "blandos", "triviales" y "acomodaticios". Esta clase de sentidos asomaban en la conversación de aquella tardecita con Nicolás y Matías. Sobre la escena platense y su relación con el rock me explayo en el capítulo $\mathrm{V}$.
} 
con las que había trabajado, para las cuales lo importante a la hora de sumar una banda era el gusto por su música combinados con ciertos criterios de amistad. En contraste, Nicolás afirmaba: "Tenemos que pensar y apuntar y tener una forma de trabajo que más o menos veamos que es similar (...) uno conoce mucho a la gente trabajando". En esta tónica, "tener una forma de trabajo profesional" fue otra de las frases textuales que apunté cuando llegué a mi casa.

En un momento de nuestra conversación, Nicolás se refirió a lo que había "tuiteado" el Secretario de Cultura del gobierno de la Ciudad de Buenos Aires. Estaba en Berlín en una feria de diseño: por lo tanto, infirió Nicolás, "no va a estar en el MICA". Tuve que preguntar de qué se trataba eso. Me contestaron que era la sigla de Mercado de Industrias Culturales Argentinas y que allí en su calidad de representantes del sello tenían unas reuniones agendadas con un grupo de japoneses y otro de franceses. Estaban preocupados al respecto porque "somos bastante cabezas con el inglés" pero habían preparado unos pendrives de 1 GB para regalarles el material editado hasta ahora por el sello. Ese objeto, que sería referido de allí en adelante como el "pendrive de Concepto Cero", lo iban a destinar asimismo a la venta en general. Por mi parte, ya estaba bastante atónita de que en esa habitación de estudiante, a la vez estudio hogareño, se estuvieran tejiendo esos vínculos, pero ellos continuaron contándome de otros "eventos de la industria" con sedes en Copenhague y en Berlín, para los que les había llegado un mail de pre selección de asistencia. Les pregunté cómo se habían enterado, sugiriendo una posible convocatoria pública. Por el contrario, me respondieron que no, que todo se había habilitado "vía Nación". El contacto con "Nación" -luego me enteraría que se referían a la Secretaría de Cultura, unos años después convertida en Ministerio- lo usaban desde que habían solicitado financiamiento para el proyecto "Los Ellos", sobre el que me extenderé más adelante en este capítulo.

Las conversaciones continuaron derivando de una en otra, abrumándome. Una hora después volví a mi casa, todavía sorprendida por ciertos aspectos del discurso de Nicolás y Matías. Esa sorpresa era comparativa con respecto a otros sellos con los que había tenido antes contacto y en relación con mis propias imágenes de lo que era la música emergente. Me había encontrado con dos jóvenes con una disposición para la actividad musical que 
estaba bastante lejos de la actitud "relajada" que había detectado en mi investigación sobre el indie platense (Boix 2011, Boix 2013).

Al mismo tiempo, su interés en la proyección de vínculos con diferentes bandas y sellos también se distanciaba de estructuras más autocontenidas, donde el "grupo de amigos" resulta, a los fines prácticos, bastante cerrado. Pero lo más contrastante con mi investigación anterior en el mundo indie -y mi concepción sobre la música emergente en general- eran las referencias al Estado y sus recursos. En muchos sentidos, la reunión acontecida me planteaba novedades y desafíos: ¿Qué prácticas específicas de gestión asumen estos músicos?, ¿bajo qué valores regulan su trabajo en la música?, ¿en qué términos establecen las relaciones con el Estado y qué consecuencias acarrea esta relación para sus organizaciones y trayectorias? En este sentido, acompañar el trayecto de Concepto Cero como sello musical confirmó para mi investigación una interrogación central: la que indaga acerca del proceso de profesionalización del trabajo musical y de las trayectorias de sus participantes, una vez que estos apuntan a hacer de la música su principal actividad laboral remunerada.

Fue también en la continuidad de mi trabajo de campo con Concepto Cero y con otros sellos que conocí a partir de las redes tendidas por el primero, entre los años 2011 y 2015, que participé del devenir de los sellos como instituciones que ampliaron su rango de acción e influencia en la música indie, "independiente" y más ampliamente, "emergente". Los sellos se multiplicaban en número y se implicaban más fuertemente en la organización de fiestas, festivales, discos colectivos, hasta llegar a la conformación redes de sellos de trabajo colaborativo. En otras palabras, los sellos resultan articuladores de las escenas. De forma consistente con estos cambios, mis interlocutores reconocieron la importancia de sus sellos, mientras para mi etnografía estos se transformaron en su objeto privilegiado, los principales articuladores de su sociabilidad musical. Así, me encontré con una construcción mucho más densa que lo que la categoría de inteligibilidad -y su fuerte dejo cognitivistapermite referenciar, y decidí el desplazamiento del foco etnográfico desde la idea de escena hacia la de sello musical. Este pasaje del análisis de la escena al sello resulta entonces de un doble tránsito: el de los propios sellos en la música emergente - de un lugar periférico a uno central y en una complejización de su estructura y su significación en estos mundos musicales- y el de mi persona por esta trama de prácticas, a medida que me iban, como 
quien dice, "cayendo las fichas", a la vez que asumía plenamente las posibilidades del método etnográfico.

Como ya explicité, realicé un recorrido etnográfico que me permitió conocer de primera mano a un sello de la ciudad, en su funcionamiento y dinámica. En ese camino, conocí a músicos pertenecientes a otros sellos de la zona metropolitana, de la provincia de Buenos Aires e incluso de otras provincias argentinas. Pude ser testigo de cómo el dinamismo con el que estos sellos realizan actividades y su multiplicación en los espacios de la música emergente ha encontrado recientemente un reconocimiento por parte de los propios actores, del periodismo especializado y de distintos organismos estatales orientados a la cultura. En el año 2012, a la vez que Juan -en ese momento músico de varias bandas de Uf Caruf, luego miembro de equipos de trabajo de Recalculando y Concepto Cero- me invitaba a escribir sobre sellos en su fanzine, programas estatales proponían como objeto privilegiado de su política pública a los sellos musicales; en la escena se armaban y desarmaban "festivales de sellos"; un programa de radio se formaba en La Plata bajo el nombre LoSellos, la versión web de la revista Los Inrockuptibles establecía una sección dedicada a los sellos musicales emergentes del país y varias notas periodísticas en medios de gran impacto nacional producían y reproducían esta situación.

Mis participaciones en el mundo de los sellos musicales siguieron la de mis interlocutores y sus trazados en la "escena" de La Plata, de modo que no pude registrar en esta investigación otras experiencias de producción y gestión musical que, identificadas a una vertiente más folk de la música local, resultan contemporáneas a Concepto Cero y sus sellos aliados. Para mis interlocutores las bandas formadoras de esta escena son identificadas con el rock, separándose de los músicos independientes ${ }^{15}$ locales que encuentran sus mayores influencias en la música brasileña, el jazz, la cumbia, el tango y, en general, la música popular latinoamericana ${ }^{16}$. El rock no se entiende como un género o estilo musical en sentido estricto, más bien demarca un tipo de sonoridad y de formación de

\footnotetext{
${ }^{15}$ La mayoría abrumadora de la música producida en La Plata se inscribe en el sector independiente, en el sentido convencional de que no tiene contratos con grandes sellos discográficos o compañías multinacionales. (Yúdice 2008: 11)

${ }^{16} \mathrm{Si}$ bien refiero a una inmensidad de manifestaciones musicales, mis interlocutores en Concepto Cero y el mundo del rock suelen asociarlas a la Facultad de Bellas Artes -sus alumnos, ex alumnos, graduados, docentes, etc. En efecto, Del Mármol et al. (2014: 12) relacionan el crecimiento de esta orientación musical en la ciudad a la creación de la carrera de Música Popular de la Facultad de Bellas Artes de la UNLP en el año 2008, además de que "una nutrida red de centros culturales, salas, pequeños sellos discográficos, radios autogestionadas y colectivos de trabajo componen, producen, difunden y alimentan el circuito".
} 
banda vinculado a la historia del rock, a la vez que una serie de actitudes "rockeras" que, llevadas al extremo, constituyen un modo de vida -tal como es entendido en diferentes mundos del rock y señalan Lunardelli 2002, Díaz 2005, Pujol 2007, Garriga Zucal 2008, entre otros. De esta manera, quedaron fuera del registro y del análisis casos como el de Cuchá Música ${ }^{17}$, una asociación de músicos dedicados a la música popular que combinan, en la escala de La Plata, ciclos de música en vivo, una distribuidora de discos y un proyecto de sello discográfico. Es probable que, en cuanto a la estructura de gestión, hubiese encontrado notas similares a las compartidas por los sellos de TICA Red habida cuenta de que integrantes de este colectivo declararon en la prensa una inspiración en el mundo del rock $^{18}$, además de que Cuchá Música participó del mismo programa de profesionalización que aquellos impulsaron en La Plata. A lo largo de la tesis, igualmente, recorreré la bibliografía reciente sobre prácticas musicales, y en general prácticas estéticas, especialmente las protagonizadas por jóvenes de grandes conglomerados urbanos, para tender comparaciones que enriquecen la etnografía.

Circunscribirme a un sello musical con acción en el mundo del rock y a los eventos a los que me condujo esa interacción fue una manera de delimitar el campo de investigación. En el trayecto de la escena a las redes de un sello musical comencé a observar una organización social alrededor de la música que, a pesar de su nombre conocido, remitía a una realidad diferente a la que construyó tradicionalmente el mercado y la industria discográfica. En este sentido, la abreviación usual por parte de los músicos de la idea de "sello discográfico" en la de "sello", resultó una primera pista de cómo sus actividades habían dejado de responder de forma única a un patrón de edición de discos, e incluso a un patrón exclusivamente musical -como se planteó históricamente en la industria musical global: Negus 2005, Fouce 2012, y también en la industria argentina: Palmeiro 2005, Corti 2007, Luchetti 2007. Nicolás localizaba ese cambio de concepción, en aquella

\footnotetext{
${ }^{17}$ Agradezco a Sergio Pujol haberme señalado esta coincidencia en una práctica de gestión, a la vez que una diferencia en la manera de identificación -dado el alejamiento relativo de emprendimientos como Cuchá Música del mundo más "rockero" en el que hice la investigación. Retomaré lo ambivalente de la categoría rock en el caso de Concepto Cero el capítulo V.

${ }^{18}$ En un diálogo con Agenda Zas, en agosto del año 2014, José Flamenco y Gisela Magri declararon: "El rock ha sabido generar espacios y grupos de trabajo, sellos, puntos de venta, etc. Nosotros estamos en un paso anterior, aprendiendo y va siendo medio artesanal, pero vamos en camino a eso. Queremos reunir a un montón de propuestas musicales platenses que no encuentran su lugar aún...”. Extraído del artículo: “CUCHÁ Músicos Platenses Produciendo: Unirse para crecer”. Disponible en la web: http://agendazaz.com.ar/site/?p=7429
} 
primera entrevista, en estos términos: “...cuando uno dice sello discográfico te imaginás Sony Music, EMI. Entonces, ¿qué hacen? Esos sellos hacen discos y hacen discos por miles, por millones todo el tiempo. Pero creo que en los últimos años el sello tiene mucho más, abarca mucho más que eso...”.

A fin de avanzar en los sentidos de estos cambios, en los próximos apartados problematizaré una serie de conceptos usuales en el estudio de estos temas y la manera en que una renovación teórica en los estudios sociales de la música los reformula, no al modo de un marco teórico general que explicaría el caso, sino como una orientación, que ayuda tanto a construir la especificidad de lo que está en juego, como a orientar el análisis del material obtenido en el campo.

\section{La música como acción y relación social}

Tradicionalmente, la sociología ha planteado la relación entre la música y la sociedad a la manera de una asociación mecánica entre una serie de obras, géneros y/o estilos musicales por un lado, y con una serie de grupos, estratos o clases sociales por el otro. Frente a una teoría estética que plantea la autonomía inverosímil del sujeto del gusto y sostiene la existencia del objeto musical sin necesidad de referirlo a la sociedad, la sociología vuelve al arte creencia planteando una relación cuyos productos son simultáneamente el objeto artístico y su admirador. Así, frente a los esteticismos, las ciencias sociales han construido sociologismos de variado calibre, según la oposición que presenta Hennion (2002). En el intento de desligarse de la ponderación normativa de los esteticismos, como también del estatuto de excepción que otorgan al objeto y a la experiencia artística, la sociología de la música se ha reducido al análisis de la producción y recepción de la música considerada como objeto, para disolverla en un juego social, ya sea de la distinción, la identidad o la lucha de clases. Fascinada por su propia iconoclasia, esta sociología pierde de vista casi completamente la singularidad de lo que pretende estudiar, operando lo que Hennion (2002: 57) 1lama "un despoblamiento del mundo de la música", convertido en traducción transparente del mundo social y equiparado, en un gesto destructor, a cualquier otra actividad o práctica. Esta sociología -especialmente la de los

discípulos bourdieanos- pierde de vista casi completamente la singularidad de su objeto y, 
en palabras de Singly (2006: 42), considera a fin de cuentas que "beber un vaso de tal aperitivo es equivalente a escuchar tal fragmento de música clásica”.

En una propuesta de superación de estos dos polos de interpretación reduccionistas en torno a la relación entre la música y la sociedad, Hennion (2002: 290) recupera para el análisis las mediaciones, los mixtos de los que está colmada la música. Refiere a una red diversificada de objetos técnicos, soportes materiales, instrumentos, dispositivos, escritos, sobre los que el músico debe operar para que finalmente emerja la música como tal. La música, entonces, ya debe concebirse en sí misma como una sociedad plena de mediaciones que la hacen aparecer. Mismo DeNora $(2000,2012)$ considera a la música un ingrediente activo de la formación social y un recurso, al contrario de lo que usualmente se supone, incapaz de trabajar separado de sus circunstancias de producción. Contra las interpretaciones sociologistas que no pueden desprender la capacidad interpeladora y productiva de lo sonoro de la noción de consumo distintivo, usos desviados o identidades sociales, DeNora afirma que la música es un dispositivo habilitante de una multiplicidad de usos. Nuevamente, no es la música como objeto sino la música como relación performativa lo que DeNora significa cuando la refiere como habilitación.

Como desplegaré en las páginas siguientes, la conjunción de estos dos autores supone un contrapunto que relocaliza un problema clásico de la tradición sociológica, el del agente y el sistema, en nuevos términos y en nuevas relaciones. Los desarrollos de Hennion redimensionan la relación entre el sujeto y el objeto en la música, y permiten observar al concepto de campo como un mediador todavía demasiado abstracto y negativo. En su lugar, Hennion propone una red de mediaciones concretas donde las cosas actúan a la par que los actores. Por su parte, DeNora amplía las dimensiones de la agencia de los sujetos en la música superando el enfoque centrado en la "apropiación" y el "uso desviado", característico de las formulaciones subculturalistas. El planteo de DeNora radicaliza la idea de uso presente en estos desarrollos y puede ser incorporado al argumento propuesto por Hennion, en tanto la agencia de los sujetos, lo que Hennion llama su "vínculo" con el mundo, será una mediación junto a otras asignables a diversos objetos, instituciones, narrativas, tradiciones, etc. Como desarrollaré a continuación, para un análisis de las formas emergentes de lo musical estos conceptos permiten operar con mayor precisión de la que 
admiten categorías como subcultura, identidad y campo, habida cuenta de que estas últimas representan los modos de abordaje más corrientes en los estudios sociales de la música.

\section{La música como una sociedad plena de mediaciones}

Las formulaciones deudoras de Bourdieu reconocen un espacio social específico donde se despliega la producción de bienes musicales: el campo musical en su conjunto o el campo correspondiente a un tipo específico de música, clasificada por un género musical, por un estilo y/o por modos técnicos de producción, entre otros criterios. El uso de esta noción implica otorgar una autonomía relativa a las prácticas musicales en un espacio que, por otra parte, no es neutro sino que está estructurado como un sistema de relaciones de competencia y conflicto entre agentes y sistemas de agentes situados diferencialmente. Estos agentes comparten cierto habitus y están investidos de una illusio (interés) al respecto de lo que está en juego en dicho espacio (Bourdieu 1983). Producto de la pregnancia de los planteos de Bourdieu en las ciencias sociales argentinas, varios trabajos han pensado los fenómenos musicales desde esta perspectiva. En lo que respecta a la temática en estudio, Vecino (2011) propone que la producción de la música independiente en la ciudad de Buenos Aires se constituye como un subcampo de producción restringida donde se produce objetivamente sólo para productores -actuales o potenciales- que son al mismo tiempo, tal como lo plantea Bourdieu (2010: 90) clientes privilegiados y competidores. Sostiene, asimismo, que esta configuración particular se vincula a las transformaciones que las nuevas tecnologías producen en el régimen de producción, circulación y apropiación de la música. Se desarrolla así una fracción heterodoxa que se autonomiza y se sustrae a los criterios de producción de la gran industria, desplegando una lógica de producción propia.

Con esta conceptualización del "campo de producción restringida" Bourdieu intentó dar cuenta para el caso de Francia de un tipo de realidad bastante diferente a la que se presenta en esta tesis. En el caso francés estudiado por Bourdieu un círculo de vanguardia se constituye en una instancia de elaboración simbólica con lógicas propias, que luego irradian hacia el gran campo de producción cultural. De esta manera, aunque el mundo musical emergente que analizo en La Plata resulte en buena medida una "sociedad de admiración mutua" (Bourdieu 2010: 91), no se constituye exactamente en una fracción 
vanguardista que disputa la legitimidad dominante a partir de la clásica idea de la pureza de un arte cada vez más separado de un público no entendido o no profesional. Estos actores, en realidad, estructuran otros modos de legitimación, basados en una lógica de producción propia, y no otros criterios al interior de un campo de la música relativamente unificado, compuesto por el campo de producción restringida y el gran campo de la producción simbólica, destinada al gran público. Para estos músicos, por el momento, la disputa se ha resuelto con un cambio de escenario y no jugando el juego al interior de un campo musical que, por otra parte, no puede a esta altura afirmarse sin conflictos. En este sentido, y en un argumento complementario, las prácticas de estos músicos no se inscriben sólo en un campo estético, como pretende la mirada de Bourdieu con el concepto de subcampo, sino que tiene existencia también en el ámbito del trabajo y en los lugares y círculos de sociabilidad que la práctica de hacer música crea y/o habilita.

Justamente, en relación a la noción de campo, en un diálogo al respecto de las nuevas prácticas culturales de la juventud en España y en México, García Canclini y Cruces (2012) sugieren que las manifestaciones artísticas juveniles que analizan -organizaciones que editan libros y discos, escenas musicales, circuitos de arte visual, etc.- romperían con el uso convencional de este concepto tal como ha cristalizado en las ciencias sociales. Para ellos, hablar de campo literario, campo musical o campo artístico -en un sentido asociado a las bellas artes- resulta inadecuado para mundos estéticos donde los jóvenes no se califican en una sola disciplina, sino que circulan entre ellas y las fusionan, buscando otras maneras de producir. Por lo tanto proponen la pertinencia de la noción de redes, curiosamente también usada por los músicos con los que acá trabajé para conceptualizar su manera de crear sociedad a través de la música. García Canclini y Cruces (2012) no se preguntan, no obstante, por la vigencia teórica de la categoría de campo para interpretar las prácticas que estudian.

Desde el vocabulario teórico de Bourdieu es posible interpretar que el mundo de la práctica musical y estética estudiado en esta tesis opera nuevas dimensiones y fragmentaciones al interior del campo de la música, como también aperturas a otros campos -en particular de la fotografía, el video y otras artes visuales, el diseño y la moda, etc.--, dadas en parte por el cambio tecnológico que permite la puesta en práctica de conexiones antes impensadas. A su vez, la multiplicación de las legitimidades que implican estas 
prácticas -que no siempre son microlegitimidades- puede atentar contra la noción de campo mismo, en tanto este es definido como un espacio donde se apuesta por el monopolio de un capital específico legítimo y en cuanto se asume que ese capital tiene una lógica y una consistencia que no tendría actualmente. Los avances de investigación, entonces, habilitan la pregunta por la existencia de una lógica de la estructuración de los campos distinta a la que propone Bourdieu, e incluso por la vigencia de esta categoría misma para el estudio de la música como organización social.

Al respecto de este problema, es necesario preguntarse si no se asiste hoy en el mundo de la música a una situación similar a la que documenta y analiza el propio Bourdieu (2000 [1982]) para el caso del campo religioso, cuando contrasta y revisa su propia teorización previa, de inicios de la década del 70 (Bourdieu 2006 [1971]). Se trata del problema de los estados históricos de un campo, donde sus fronteras -y por lo tanto, las que guarda otros campos- también se plantean como un producto de la historia. En el caso del campo religioso, Bourdieu sostiene que ya no habría límites precisos, claros, tajantes, entre "el reino de los clérigos" y otros campos, en particular el de la medicina y el de la psicología, que hacia comienzos de los ochenta ya disputaban claramente con la religión la cura de los cuerpos y de las almas en el marco de una redefinición de la división y oposición binaria entre estas categorías.

En el caso empírico que desarrolla esta tesis, la incorporación por parte de los músicos de la necesidad de encarar de manera activa y diferente las relaciones con el mercado y con el Estado, es decir, en la centralidad que adquiere para ellos la gestión como en su reivindicación de dicha necesidad- es posible entender un cambio en lo que se considera que debe ser un músico. Este proceso, del cual esta investigación es contemporánea, va acompañado de prácticas habilitadas por nuevas tecnologías, ahora mucho más accesibles al gran público, que permiten una relación diferente con los medios de producción y reproducción de música: desde grabar en la propia casa hasta utilizar la música previa como dato a ser intervenido y no sólo a ser reproducido. Asimismo, la producción y la presentación de música no se encuentran separadas de las artes visuales, plásticas y escénicas, en muchas ocasiones realizadas por las mismas personas ${ }^{19}$. En

\footnotetext{
${ }^{19}$ Es verdad que en particular las bandas de rock siempre conectaron en sus shows y en sus discos la música con otras artes, la ficción, el cine, las artes visuales. Las nuevas tecnologías permiten realizar esto con menos recursos y en sinestesias antes impensadas.
} 
mundos musicales como el que Concepto Cero transitaba era usual encontrarse con creadores que mezclan en directo loops de vídeo e imágenes mientras toca la banda generalmente llamados "VJs", del inglés videojockey ${ }^{20}$, con músicos que realizaban el arte de tapa de sus propios discos - e incluso que los producían materialmente ellos mismos, uno por uno-, con eventos donde la música en vivo era acompañada de pintadas de paredes o murales, muestras de fotografía y artes plásticas, recitadas de poesía y hasta cortes de pelo. En este marco, a nivel de las trayectorias personales, se trata de músicos que tienen formaciones y orientaciones artísticas que exceden la música. En este punto, la construcción de un mundo prosumidor altera no solamente la categoría de los bienes sino también las relaciones entre las personas que consumen/producen esos bienes. De esta manera, nuevamente en un lenguaje bourdieano, lo que cambia es la dinámica de producción de campos y no sólo su frontera.

Resulta difícil ceñir el patrón de producción musical que resulta núcleo de esta tesis a la fijeza del concepto de campo tal como ha cristalizado. En tanto los desarrollos bourdieanos tienden a estructurar el análisis de las prácticas estéticas de una forma legitimista o dominocéntrica (Grignon y Passeron 1991), la vocación desromantizadora originaria de Bourdieu al respecto de la estética pura se ve subvertida en la identificación del análisis con los criterios de la cultura dominante -ya que, al descubrir el arte como creencia y dominación simbólica, se dificulta reconocer las prácticas más que ubicadas de mejor o peor manera en relación con la legitimidad. En este punto, ante la concepción petrificada del campo que naturaliza las divisiones sociales, y por lo tanto en lugar de ver al arte como hecho social -en su constitución misma- lo concibe como obra, como un objeto dado -y ya dado por la definición dominante-, es iluminador volver a la noción de "mundo

\footnotetext{
${ }^{20}$ Los VJs se encargan de generar imágenes con medios digitales que se proyectan en lienzos o pantallas en los locales de música en vivo. Estas imágenes son denominadas "visuales" y muchas veces son procesadas en tiempo real a través de una computadora. Blázquez (2012) indica como en Argentina esta figura tiene sus inicios en la escena electrónica dance: "el abaratamiento de notebooks y proyectores, así como el desarrollo de softwares gratuitos disponibles en diversos sitios de Internet, permitieron que un creciente número de sujetos accediese a este tipo de práctica artística que se desarrolló junto con el crecimiento de los "clubs electrónicos" (Blázquez 2012: 8). En la escena emergente de La Plata, existían casos como el de Brahmán Cero -el proyecto musical que Nicolás tuvo hasta el año 2013- donde los Vjs eran miembros plenos de la banda y negociaban con ella la estética y el contenido específico de su puesta. También los Vjs podían trabajar codo a codo en la identidad visual de los sellos, tal como sucedía en Concepto Cero. Pero lo más usual era que los Vjs fueran convocados a trabajar en fechas puntuales por un sello o una banda.
} 
de arte" de Becker (2008), quien devuelve a los objetos de la vida estética su carácter de objetos sociales.

El planteo beckeriano supone que el arte no es un objeto que el sociólogo pueda definir sin atender a la red de relaciones en que ese objeto surge. Más bien, el arte para Becker es el producto del trabajo de una red de cooperación organizada convencionalmente para producir obras/productos que el grupo en análisis define como artísticos. En el caso de Concepto Cero y otros sellos de la escena, esta red se extendía a los específicos espacios y momentos en que se produce música en su sentido sonoro convencional -emplazando la observación en los recitales, los ensayos y otros momentos de aparición de la música- y también en una variedad de fiestas, talleres, conferencias, reuniones y otros encuentros grupales. Así pude considerar para mi etnografía la relevancia $-\mathrm{y}$, a veces, el carácter constitutivo- de ciertas prácticas de sociabilidad grupales que si bien un observador externo separaría de dicho patrón son, sin embargo, constitutivas del mismo. En otras palabras, rastrear la red -en el sentido de Latour $2008{ }^{21}$ que hacía aparecer la música volvió necesario el acceso a una amplia variedad de prácticas cotidianas de estos actores. En el mismo sentido, en una discusión con la estática noción de gusto de Bourdieu (1998), reducida esta a la correspondencia con una posición en el espacio social, Hennion (2012) plantea que los festivales, las danzas, las drogas y estimulantes, la ropa, las relaciones sexuales, entre otras prácticas, definen las condiciones del gusto musical en la actualidad, por lo que no es posible disociarlas del estudio de la música.

Análogamente al camino que Bourdieu emprende críticamente contra sí mismo en el ya citado artículo "La disolución de lo religioso" (2000), es posible pensar que el desmoronamiento de la frontera del campo musical se vincula, justamente, con los cambios en la definición misma del músico y de la música. Al distinguir un nuevo estado del campo religioso, Bourdieu realiza de forma indirecta una reflexión sobre el propio concepto de campo e instala la sospecha sobre ciertos usos de esta noción que naturalizan lo que son más bien sus estados históricos. En este sentido, de la misma manera que la religión ya no se puede definir más por la cura de almas -lo que suponía una división cuerpo/alma que de

\footnotetext{
${ }^{21}$ Con esto refiero a que he orientado mi trabajo a describir las distintas actividades, objetos, categorías, narrativas y actores que hacían aparecer la música en mi campo. Rastrear la red no implica entonces describir una red -o actores relacionados bajo la forma de una red- sino concebir el método de construcción del objeto a partir de esa forma. (Latour 2005: 207)
} 
igual modo dejó de existir-, ciertas músicas ya no pueden pensarse a partir de las nociones tradicionales de obra, artista y público. En otras palabras, las prácticas y agentes específicos de un campo en un momento particular de su desarrollo producen una forma particular de practicar y entender la música, con lo que definen sus propios límites y su sistema de relaciones internas. En su aparente sencillez, la noción beckeriana de "mundo del arte" ya suponía este argumento al considerar que la trama organizativa creadora de arte es también productora de la legitimidad de los criterios estéticos $-\mathrm{y}$, por lo tanto, de la distinción entre qué es arte y qué no lo es. Esa intuición a la que ciertos usos de Bourdieu no permiten permanecer fieles, sí es acompañada y profundizada en la interpretación de Hennion (2002), que por un lado atiende la red social, y por el otro, a diferencia de Becker, no ignora las relaciones de dominación propias de esas redes sociales.

El planteo de Hennion intenta retener la dimensión de flujo social en la constitución de la música, donde intervienen no sólo actores sino también objetos de capas múltiples. Considera que no hay que tomar la música como un objeto de buenas a primeras porque esta es en sí misma un evento donde no es posible disociar la música propiamente dicha de sus mediaciones: instituciones, objetos técnicos, soportes materiales, instrumentos, sentido en el cual la mediación apunta a una operación heterogénea que no hace distinción entre humano y no humano. Como se presentó con anterioridad, la música para Hennion es el resultado de estas mediaciones, o más bien, la música es la relación de mediación misma. Es decir, la música es en sí misma una relación social, un hacer inextricablemente ligado con prácticas que no son musicales en un sentido estricto sonoro y con tecnologías y dispositivos que imprimen su huella en la música que se produce. Por ello, la música ya es en sí misma sociedad y no una metáfora, reflejo o expresión de lo social. En realidad, la relación de constitución recíproca entre música y sociedad no es una novedad imputable a Hennion: como desarrollo en el siguiente apartado, la crítica al subculturalismo también avanza en esta dirección, pero mientras esta enfatiza el carácter de esferas relativamente incompletas de música y sociedad que se interpenetran, la posición de Hennion es más radical al entender a la música directamente como una red de mediaciones eficaces que la producen. 
En este contexto, la noción de mediación supone una operación activa, productora, inseparable de los objetos, asignable a actores y actantes ${ }^{22}$ que deben ser identificados por el análisis. Con respecto al caso en estudio, surge la pregunta al respecto de qué es lo que esa mediación ha permitido y permite hacer, es decir, qué cursos de acción habilita. Mi interés fue desplegar y establecer el rol activo de las mediaciones concretas en el estudio de una forma específica de instituir y de practicar lo musical, centrada en un sello donde la gestión se realiza entre amigos. Lo hice intentando ser fiel a la prescripción de que la música en sí misma es un ejercicio activo de mediación donde no juegan sólo los actores sino múltiples agencias.

\section{La música como habilitación de una pluralidad de usos}

En el marco de los planteos ocupados en pensar la articulación entre música y sociedad, el subculturalismo se proyecta como una tradición muy fuerte. Dentro de los estudios culturales ingleses, este grupo de investigadores abocado a estudiar subculturas jóvenes de clase trabajadora puso el foco en el problema de la diferenciación social a partir de un principio de estilización. Estos investigadores se centraron en mostrar cómo las diferentes subculturas juveniles identificadas -comúnmente de forma espectacular- por sus posesiones, escuchas musicales y objetos, construyen un estilo a partir de esas apropiaciones: no se trata de meras cosas tomadas (o escuchadas). La estilización implica una organización activa de objetos ofrecidos por el mercado -vestimenta, música, accesorios, etc.- en una coherente y distintiva manera de "ser en el mundo". Se trata del uso de objetos particulares que podían homologarse a los intereses grupales, sus actividades, su estructura misma de grupo y su autoimagen colectiva (Hall y Jefferson 2010). Resituar y recontextualizar las mercancías abría la posibilidad de subvertir sus usos convencionales, pudiendo encontrarse lecturas nuevas y encubiertamente opositoras de los

\footnotetext{
${ }^{22}$ La noción de actante en la sociología de Latour -la cual retomo en este caso de la reconstrucción de Nardacchione 2011: 178- reemplaza a la noción de actor, introduciendo al menos dos novedades. Primero, el actante se integra a una trama narrativa dentro de la cual cobra sentido su acción. Segundo, actante puede referir a una gran cantidad de entidades: una persona, un colectivo, una organización, un objeto, un relato, etc. Todos estos usos del término comparten una distancia con la clásica carnadura subjetiva -heredera de una filosofía de la conciencia- a través de la cual ha sido usada la noción de actor.
} 
artículos más estandarizados. Usos irónicos y sacrílegos de artefactos "sagrados”, usos "incorrectos" del lenguaje, en fin, usos ilegítimos de los objetos que convivían con sus usos legítimos y convencionales (Hebdige 2002). A partir de estas orientaciones, los subculturalistas se proponían examinar concretamente y en profundidad una región de la cultura contemporánea, que debía ser entendida en su completa especificidad, para luego indagar cómo podría estar conectada a estructuras culturales y sociales más amplias (Hall y Jefferson 2010).

En cuanto a la música, la forma subculturalista de concebir las membresías musicales ha sido muy criticada: no puede dar cuenta de la fluidez en la que se coproducen la música y las categorías sociales -clases, grupos, "jóvenes", etc.- ya que supone relaciones de necesidad en la conexión entre ciertos estilos musicales y ciertos actores sociales, además de que es incluso inflexible para reconocer las variaciones al interior de las subculturas. Aún cuando el subculturalismo fue criticado en sus fundamentos, el planteo hasta hace pocos años generalizado en los estudios sociales de la música que parte de estudiar un género $-\mathrm{o}$ estilo- musical en relación a una clase social $-\mathrm{o}$ fracciones de la misma- implica una fuerte orientación hacia esa tradición, perdiendo incluso muchas veces la fuerte densidad y riqueza con que los estudios originarios trataban la experiencia de clase.

En la academia local, las formulaciones subculturalistas se han utilizado para entender la práctica musical a partir de su oferta de mensajes para la conformación de identidades de grupos previamente definidos. Es paradigmático en este sentido el trabajo pionero de Vila (1985) sobre el rock nacional, donde se muestra cómo los “jóvenes" utilizaron una música, el "rock", en la construcción de un movimiento social antidictatorial. Al proponer al rock nacional como ámbito de constitución de un nosotros generacional, Vila introduce la noción de una música de uso (1987a). Como el tango y el folclore en su momento, el rock nacional fue propuesto como un movimiento social en el que puede identificarse a un actor social específico que usa esa música como soporte de su identidad.

Años después, Vila (1996) admitió que dibujó con trazos muy gruesos a los actores sociales, adscribiéndoles ciertos intereses ligados a su posición social y relacionándolos con ciertas expresiones musicales bien definidas que, de acuerdo a la homología estructural 
construida, los representaban. En la identificación de los jóvenes con "lo rockero" se perdía de vista la heterogeneidad de las adscripciones musicales: si se considera que el movimiento social del rock es caracterizado como policlasista (Vila 1985: 145) y compuesto por diferentes fracciones de las clases medias y sectores populares -0 "la gente de los suburbios”, Vila 1985: 143-, el análisis suponía que todos los jóvenes de esas clases eran rockeros. Asimismo, estos jóvenes aparecían clasificados en distintos grupos dentro del movimiento en homologías con su posición social -“la gente de los suburbios" con el "rock pesado", la clase media baja y media con el "rock nacional", la clase media con el "punk". En ese argumento se ignoraba que estos estilos no eran igualmente antidictatoriales ni se correspondían unívocamente con esos sectores sociales.

A partir de esta autocrítica, y como solución al problema del razonamiento homológico, Vila (1996) construyó un instrumento analítico centrado en la articulación entre interpelaciones musicales y narrativas identitarias. Al retomar una serie de planteos críticos -en particular el de Frith $2003^{23}$-, introdujo la cuestión de las identificaciones plurales para una misma música: no existe un grupo ya constituido que luego se expresa en sus actividades culturales sino que la música como práctica articula en sí misma un proceso tanto social como estético en el que las personan le dan sentido a las relaciones grupales e individuales. De esta manera, se podía entender que algunos actores sociales se relacionaran con la identidad de clase que una música proponía, mientras otros podían usar esa misma música para expresar su identidad de género. Esta dinámica de interpelaciones y narrativas perforaba la lógica de la homología, a la vez que se abría a otras líneas de conflicto que respondían a dimensiones distintas de la clase social. Las narrativas se convertían en el lugar de significación de cualquier interpelación, tal como lo ejemplifica el autor con respecto a los usos del tango por parte de las mujeres y de los obreros, cautivados por una música que los denigraba. Vila sugería entonces que "dichos actores sociales valoraron más el mensaje étnico del tango que su mensaje de género o de clase" (Vila 1996: $\mathrm{s} / \mathrm{n})$. De este modo, el planteo llevaba en sí mismo la posibilidad de un análisis "más acá de la hegemonía" -tal como lo define Semán 2011-que fue realizado por trabajos que le siguieron, como los que indagan acerca del gusto de las mujeres por la cumbia villera e

\footnotetext{
${ }^{23}$ Para Frith (2003) la capacidad interpeladora de la música es muy poderosa en tanto trabaja con experiencias emocionales particularmente intensas: las personas gozan de la música popular porque esta da respuesta a cuestiones de identidad.
} 
incorporan otras dimensiones de la música además de la letra. (Vila y Semán 2006, Silba y Spataro 2008)

En el contexto argentino, el planteo de Vila resultaba solidario con la discusión sobre la apropiación de los productos de la cultura masiva que proponía De Certeau (2008) y que tenía como contradictores privilegiados a Bourdieu y Foucault. Los bienes culturales podrían tener sus propias instrucciones de uso pero los sujetos violaban dichas codificaciones en un uso singularizado por sus circunstancias. El consumo, generalmente condenado a la pasividad por la teoría sociológica, podía convertirse en un lugar de desafío y disputa a partir de la resignificación operada por los sujetos. De esta manera, la noción de uso se entendía desde la posibilidad de simbolización alternativa que los sujetos en tanto tales guardaban en sí mismos.

Contemporáneamente a estos desarrollos, se multiplicaron en la academia local estudios que ponían el foco en la práctica musical entendida como una arena para la construcción de sentido -con especial interés en los que podían ser considerados desviados y resistentes- por parte de grupos sociales, casi siempre juveniles. La música aquí se define por su uso en una valencia específica: ofreciendo distintos mensajes con los cuales las personas pueden resolver cuestiones identitarias. En esta línea, ya sea desde un abordaje de la producción de identidad o de la construcción de identificaciones, muchos trabajos se dedicaron a considerar a la luz de la historia argentina reciente las prácticas de consumo, interpretación y circulación de determinadas expresiones musicales, especialmente de aquellas que se consideraban centrales en la experiencia de los sectores populares: la cumbia y el rock chabón o barrial (Elbaum 1994, Semán y Vila 1999 2006, Cragnolini 2006, Míguez 2006, Semán 2006, Alabarces et al. 2008, Benedetti 2008, Garriga Zucal 2008, Martín 2008). En estos trabajos, el interés en los fans, los seguidores, los escuchas, obedecía en parte a la tesis de que, a la luz de la reestructuración social neoliberal, las narrativas identitarias -especialmente las juveniles- se construían más bien en torno a prácticas culturales y repertorios simbólicos ofrecidos desde las industrias culturales, antes que a través de instancias socializadoras clásicas como la familia, los partidos políticos, el trabajo, los sindicatos y la educación. (Svampa 2005)

Muchos de estos trabajos, sin embargo, reprodujeron cierto mecanicismo en el análisis de la relación entre música e identidad, cuando ya la crítica de Vila (1996) en su 
análisis del rock como movimiento social aglutinante y productor de una identidad juvenil anti dictatorial había cuestionado los supuestos de una lógica de la identidad plena. Más recientemente, algunos autores han planteado que las nociones de identidad y de identificación comprimen las razones por las que se supone que un "joven” se aproxima a la música (Semán 2011). Esta autocrítica lee en la producción local una reducción de la agencia estética a la capacidad cognitiva o interpretativa de los oyentes, que se limitan a dar sentido a los productos musicales que se les ofrecen. Pero: ¿cuántas cosas pueden hacerse con objetos -incluyendo sonidos-, y de hecho se hacen, además de producir identidades e identificaciones? En convergencia con estudios que han planteado una ampliación e individualización del menú musical habilitado por las nuevas tecnologías (Semán y Vila 2008), se ha avanzado hacia la ampliación del concepto de uso en la música para entenderlo no sólo en sus dimensiones identitarias o bien como subversión o desvío frente a las prescripciones convencionales, sino como un concepto que se desplaza del plano de la apropiación al plano de la acción social misma.

El procesamiento de la edad y la conformación de subjetividades femeninas en el caso de las fans de Ricardo Arjona (Spataro 2012), la forma de comunicación a partir de lo corporal y las relaciones físicas en el baile electrónico en relación a la articulación moral que lo acompaña (Gallo 2011b), las formas en que la música produce profesión en un colectivo de Dj's (Irisarri 2011), las normatividades en el baile en relación con las prácticas íntimas en ámbitos propios del tango milonguero y las milongas (Carozzi 2009 2011), el trazado de trayectorias morales a partir de la pasión por la ópera (Benzecry 2012), la formación de los cuerpos y las subjetividades en el marco del baile del cuarteto y la pista electrónica (Blázquez 2008, 2009, 2011) son algunos de los estudios donde el uso de la música encuentra una radicalidad, refiere al sujeto mismo, a la vez que restituye las dimensiones del cuerpo, los sentimientos, la moralidad, los proyectos, las carreras, a la problemática de la agencia estética, restringida muchas veces en la bibliografía a los aspectos de la interpretación de un mensaje por parte de un oyente.

Es el planteo de DeNora $(2000,2012)$ en el campo de la sociología de la música el que permite entender el giro señalado. DeNora (2000) relee los materiales etnográficos de algunos investigadores subculturalistas desligándolos del marco homológico y de la pretensión totalizadora de los estudios culturales para entenderlos dentro de una teoría de la 
música como acción. Retoma a los bikeboys, informantes de Willis (1978), para plantear cómo la música tiene el poder de llevar a las personas de un estado a otro. Palabras de uno de los muchachos de Willis argumentan que la música es un vehículo cultural, que puede ser montado como una moto o abordado como un tren: "if you hear a fast record you've got to get up and do something, I think. If you can't dance any more, or if the dance is over, you've got to go for a burn-up [motorcycle ryde]" 24 . De esta manera, para DeNora uno de los más llamativos y pioneros aspectos de la obra de Willis, generalmente subestimado, es su concepción de la música como un recurso activo de la formación social y no como algo que se relaciona con ella, como mero medio "significante" o "expresivo". Semán (2011: 23) construye un caso basado en la bibliografía especializada para ejemplificar esta diferencia: una cosa es que una letra de música popular sea interpretada en un sentido místico, otra es que "al oírla, se viva esa canción (que no era para nada mística) como una forma de oración (supongamos el caso de un joven practicante zen que tiene en un determinado rap la perfecta articulación rítmica para finalizar su práctica diaria)”.

Es en esta dirección que para DeNora la música debe entenderse en tanto "acción": como práctica y como proveedora de una base para la práctica. En este sentido, la categoría de habilitación -la affordance ${ }^{25}$ - aborda la música como medio formativo en relación con la conciencia, el cuerpo y la acción, como recurso -más que como medio- para la construcción y proyección del mundo. Entonces, hablar de la música como un dispositivo habilitante significa decir que la música es algo con lo que se actúa y sobre lo que se actúa. El foco nuevamente se aleja de lo que la música describe o de lo que puede leerse en la música sobre la sociedad, para acercarse a aquello que la música posibilita, es decir habilita como un proceso social en sí mismo. De esta manera, se pone de relieve el potencial de la música como medio organizador, como algo que contribuye a estructurar los estilos de conciencia, las ideas, los proyectos. Para DeNora, la música es constitutiva de la vida social: su despliegue como acontecimiento tecnológico, que toma cuerpo en una performance, requiere su conceptualización como una acción social en sí misma.

\footnotetext{
${ }^{24}$ Willis 1978: 72, citado en DeNora 2000: 7

${ }^{25}$ Derivado del verbo to afford-que podría traducirse como habilitar-, este concepto invita a pensar aquello que permite -y que no permite- un objeto, o dicho más estrictamente: los cursos de acción, las maneras de ser, de hacer y de sentir, que habilita un objeto en el proceso de su apropiación.
} 
En este recorrido, la noción radicalizada de uso de DeNora se encuentra con los desarrollos de Hennion (2010), quien a propósito de los amateurs y en una nueva crítica a la sociología "crítica", propone abandonar el uso de la palabra "gusto" por otro vocabulario que remita mejor a la variedad de configuraciones que puede tomar el vínculo o la vinculación hacia la música. En una polémica contra la estática noción de gusto bourdieana, Hennion propone sustantivos como amor, pasión, hábitos y manías pero sugiere que estos tampoco son suficientes cuando el objetivo es dar cuenta de un vínculo del sujeto con la música que por definición es singular. La idea de vínculo rompe con la acentuación en el dualismo sujeto-objeto y da cuenta de una relación en la que se producen al mismo tiempo el "degustador" y el objeto de su gusto. Tal como el concepto de mediación, el de "vínculo" no sintetiza una serie de prácticas sino que invita a desplegarlas. Interroga sobre las operaciones y actos precisos, los dispositivos y técnicas, los entrenamientos, sobre los que es necesario apoyarse para sentirse identificados con la música o, como dirían mis interlocutores en Concepto Cero, para "estar en la música".

Retomando el desarrollo anterior, podría afirmarse que, mientras en los planteos bourdieanos y subculturalistas lo social aparece penetrando, produciendo o contexualizando la música, en los enfoques de Hennion y de DeNora la relación entre la música y la sociedad no es de exterioridad, sino de imbricación. No debe ir a buscarse lo social en la música -convirtiendo a esta en un reflejo, una expresión, una metáfora, una manera de manifestación de lo social- porque la música ya es social y produce sociedad por sí misma. Específicamente, con respecto al caso que en esta tesis se analiza, Hennion permite detectar una nueva sociabilidad musical, mientras DeNora propone captar una pluralidad de usos, ampliando esta categoría. Los aportes de ambos conducen a una nueva agentividad musical: es de una red de múltiples agencias que surge la música. A partir de la conjunción de estos dos aportes, es posible preguntarse por la habilitación de proyectos musicales de nuevo tipo a partir de instituciones musicales como los sellos musicales que, si bien no son enteramente nuevas, se configuran para los sujetos de la generación en análisis de un modo distinto, y como sostendré, novedoso, permitiendo otro tipo de relación con la música y con los medios de producción de música, siendo interpretadas de esa manera por los músicos con los que realicé esta investigación. 


\section{Una nueva música de uso}

Originalmente, la idea de una "música de uso" (Vila 1985, 1987a, 1989) permitió pensar la existencia de una música representativa de una época, y de un sector social. En el caso del rock este actor social fue la juventud, entendida en estos trabajos a la manera de la combinación de un rasgo etario con una configuración socio cultural que la instituye como un actor socio-culturalmente relevante. Esta noción de música de uso estaba pensada desde las categorías de identidad, de movimiento social y de género musical: se trataba de una asociación analítica que suponía un uso de la música basado en la identificación, que esperaba una perspectiva de actuación política para una comunidad interpretativa (Semán 2011), y que englobaba bajo el género del rock músicas que luego de la reapertura democrática se fragmentarían en multitud de géneros específicos (Alabarces et al. 2008), mostrando el carácter contingente e histórico de estas construcciones generalmente naturalizadas. Esta pauta exclusivista, única y homogénea en la relación de los sujetos con la música (Semán y Vila 2008) no puede predicarse luego de esa fragmentación -quizás nunca haya sido posible, pero los análisis estaban justamente limitados por la particularidad histórica del movimiento del rock en la conformación de fuertes identidades colectivas. La reformulación de Vila (1996) de la idea de "música de uso" se escribe al ritmo de dicha fragmentación: en ella los distintos actores sociales se apropian de una misma música de manera diferenciada. Esta noción evolucionó en al análisis que Vila y Semán (1999), y luego más detenidamente Semán (2006), hicieron sobre el llamado "rock chabón” como una forma de versionar el rock nacional de clase media a partir de la experiencia de las nuevas generaciones, esto es, jóvenes de sectores populares que vivieron y constituyeron allí ya no una invocación anti-sistema sino una narración del déficit de integración social.

En los últimos años, la bibliografía especializada ha analizado, en el marco de las transformaciones estructurales de la sociedad argentina, la expansión de prácticas que le otorgan un papel más central a las industrias culturales, los espectáculos y el tiempo libre, incrementando la auralidad de la experiencia (Yúdice 2007), y la expansión de diversas categorías de música de uso. Al haber incorporado las críticas a la forma taxativa en que se vinculó el uso de la música con la identidad, estas intervenciones ya no se centran en los problemas de la identidad y las identificaciones. Son estudios que se han revisado a sí mismos como tradición, al mismo tiempo que se hacen cargo de prácticas musicales que 
diversificaron sus posibilidades de uso: Semán y Vila (2011: 37) han avanzado en la noción de una música de uso para el caso de la cumbia villera; Gallo (2011) para el caso de la electrónica dance. Más recientemente, Gallo y Semán (en prensa) entienden que para las nuevas generaciones el lugar de un lenguaje común provisto por un género musical es reemplazado por una forma de acción colectiva habilitada por un modus operandi novedoso en la producción y el consumo de música. Este nuevo tipo de uso de la música se articula a partir del encuentro de una generación y unas posibilidades estéticas y tecnológicas que no existían en la época del imperio de las discográficas. En las últimas dos décadas, este encuentro compromete a músicos y públicos de manera activa en el despliegue de múltiples pequeñas escenas.

De la misma manera que en 1985 Vila describió el espacio del recital y su funcionamiento como refugio frente a la política de la dictadura cívico-militar, habilitando una lectura acerca de la organización de una sociabilidad joven a partir de una música -en un marco de desarticulación colectiva y restricción feroz de la oportunidad de estar con otros-, hoy puede describirse a estas pequeñas escenas como una clave de las formas de sociabilidad musical juvenil. Puede pensarse que en estos espacios la música es una relación social que en su propia actualización amplía las posiciones mediante las cuales es posible participar de la música, y por lo tanto, volverla acción social, especialmente a partir de la extensión de la agencia estética que traen las nuevas tecnologías. Así, debe entenderse que para los participantes de estos mundos musicales la música no es algo que meramente se escucha, sino que se trata de una práctica en la cual están comprometidos, es la consecuencia de una acción definida de forma singular, a la vez que un recurso para relacionarse con otros y crear lazos, relaciones e instituciones.

De esta manera, entendiendo lo musical como relación social -creador de sociabilidad y organización social- los usos de la música relevantes a esta tesis se asientan en el terreno de su producción misma, además de responder a cuestiones identitarias y de sensibilidad. Se activa en estos colectivos como Concepto Cero una nueva forma de producir y de relacionarse con los medios de producción, es decir, una manera novedosa y generalizada de uso de la música ampliado y pluralizado por las nuevas tecnologías. Asimismo, en el marco de estas relaciones, la música no puede ser más que el resultado de un agenciamiento con música, por lo que su uso se imbrica en dimensiones constitutivas de 
la subjetividad. Sintetizando, a partir del análisis empírico de este campo, puede pensarse una nueva música de uso a partir de las dimensiones generalizadas de un tipo de relación con ella y sus medios de producción.

\section{La etnografía desde las mediaciones de una historia}

La experiencia etnográfica en la escena indie de La Plata y alrededor de su sello musical más importante, Laptra, a la vez que las prescripciones de Hennion (2002) para el estudio de los fenómenos musicales, me exigieron observar y registrar las interacciones no sólo en los ámbitos que parecen musicales por excelencia -el recital, el ensayo, el estudiosino también en ámbitos que desde una posición exterior se podrían categorizar como extra musicales -conferencias, talleres, cumpleaños, fiestas, viajes, reuniones. Pensar la música como acción social y relación social, es decir, como una instancia social por derecho propio, implicó describir una red de mediaciones -agenciadas tanto por actores como por actantes- para que finalmente sea producida, emerja ante nosotros, la música, una vez que esta ha dejado de pensarse como un objeto dado. El trabajo, entonces, se orientó a describir las distintas actividades, objetos, dispositivos, categorías, narrativas y sujetos que hacen aparecer la música. Rastrear la música ha implicado concebir el método de construcción del objeto a partir de la noción de una "red" (Latour 2005: 207). Así, sólo en el esfuerzo de descripción e interpretación de un mundo musical en sus distintas dimensiones es posible comprender su densidad, prescripción que coincide con el abordaje etnográfico elegido.

Realicé la investigación plasmada aquí en parte, entre mayo de 2011 y fines del año 2015, cuando definitivamente me puse a escribir esta tesis y no pude asistir más a los eventos que me proponía Concepto Cero. El período sobre el cual esta tesis realiza sus afirmaciones comprende entonces casi cinco años, entre 2011 y 2015 . En general, lo que de manera un tanto exagerada para mi caso podría llamar “campo" (Peirano 1995: 36) -quizás remitiendo anacrónicamente a una forma de hacer investigación donde la idea de viaje es central (Clifford 1999) - ya era parte de mi vida mucho antes del comienzo de la investigación. En el año 2009, momento en que inicié las observaciones y entrevistas para mi tesina de licenciatura, lo hice a partir de mi conocimiento previo como espectadora regular, y durante todo el período posterior a 2011 no dejé de relacionarme como 
espectadora con otras bandas y sellos de La Plata. Este mundo musical continuó su movimiento pero ya no fue registrado por mí, si bien no me es para nada ajeno: mi vínculo con la música sigue la corriente que proponen los artistas con los que investigué, mantengo relaciones de diferente tipo con algunas bandas y músicos que conocí, muchos de mis amigos son habitués de la escena.

Luego de presentar mis intereses de investigación a Nicolás y a Matías -su socio en Concepto Cero hasta fines del año 2011-, el trazado de mi camino en las redes que ellos y sus amigos me fueron habilitando se dio principalmente a partir de la participación en: (1) las reuniones internas del sello; (2) los eventos públicos que allí se organizaban, básicamente recitales, festivales y fiestas, aunque también viajes a recitales en Capital Federal, cenas y almuerzos con miembros de otros sellos de la música "emergente" local, entre otros encuentros; (3) el pasar el tiempo con ellos, bajo la forma de desayunos, tardes de mate y salidas nocturnas; (4) las interacciones en grupos privados de Facebook, chats y tweets $^{26}$. Mi acceso a estos diferentes espacios no estuvo dado de antemano: cada uno de ellos fue una conquista y se asentó sobre la confianza que pude ir ganando a partir de mi permanencia en las redes del sello y mi compromiso con sus actividades. Pero también mi incorporación a estas redes contaba con ciertas condiciones previas: la de compartir ciertos espacios con los que serían interlocutores de la investigación antes de interactuar con ellos en plan etnográfico.

Nicolás, Matías, sus amigos, sus relaciones con la cuidad, sus trayectorias universitarias, se tocaban en algunos puntos con los míos, revelaban una plataforma cultural compartida en nuestro carácter de universitarios, jóvenes, habitantes del llamado "cuadrado" de la ciudad de La Plata y capitalizados de una u otra manera por vía familiar una estadía prolongada en la casa de la familia nuclear o de miembros de la familia, el sostén de los estudios y/o el alquiler pago por parte de los padres, entre otras situaciones. Fue así que no sufrí la sospecha inicial en que la etnógrafa es percibida como una outsider amenazante del orden (Golde 1986, citado en Moreira 2006). De todos modos, ellos

\footnotetext{
${ }^{26}$ Considero las interacciones en las redes sociales virtuales parte constitutiva de la etnografía realizada. Estas tecnologías se encontraron siempre imbricadas con las interacciones cara a cara, son coextensivas a las prácticas de producción musical, por lo que no entiendo las interacciones virtuales bajo la noción de una etnografía virtual (Hine 2004). En este sentido, no resulta casual que sea un contacto previo sostenido por las redes sociales virtuales el que inicia mi recorrido en las redes de Concepto Cero. La discusión del papel de las redes de amigos, físicas y virtuales, en la configuración del sello musical se desarrolla en diferentes momentos de los próximos tres capítulos.
} 
percibieron la extrañeza de la situación, que manejaron en forma de bromas y preguntas recurrentes sobre qué era lo que yo estaba haciendo allí, además de solicitarme pruebas sobre mi confiabilidad: incluso en noviembre del año 2011, siete meses después de mi acceso al campo, varios de ellos - comandados por uno de los artistas visuales- me pidieron una reunión para que volviera a clarificar ante ellos mis intereses de investigación. En coincidencia con esto, en las primeras entradas de mi diario etnográfico se revela muchas veces una incomodidad: en varias ocasiones no sabía qué hacer o qué decir, no entendía de qué se hablaba, me sentía fuera de lugar, etc.

Poco a poco, pude establecer relaciones de mayor confianza y, como muestro a lo largo de la tesis, encontré una forma de "volverme amiga" en los términos del grupo analizado. La incomodidad inicial dio lugar a relaciones estrechas con algunos de estos músicos y al trabajo conjunto en varios aspectos de su práctica musical: desde vender discos, hacer la "taquilla", participar como extra de un video-clip, discutir sus flyers, corregir los textos que tenían que escribir en sus presentaciones, hasta implicarme en intercambios bibliográficos. Los músicos con los que traté estaban tan interesados como yo en las características de sus prácticas musicales, en el carácter de su novedad, en los cambios en la estructura de la música, y esto condujo a que la relación de campo terminara por contemplar discusiones sobre mi tesis de maestría o los artículos que publicaba, tal como desarrollaré en el capítulo III. La investigación se planteó en términos de interlocución y de un diálogo conscientemente dirigido a objetivar y darles perspectiva histórica y futura a estas prácticas. Al llamarlos interlocutores en esta tesis, entonces, hago mía una apuesta por singularizar y volver objeto de la reflexividad la relación investigador/investigados, tal como lo plantean desarrollos contemporáneos de la antropología (especialmente sigo a Borges 2011 y Ferraudi Curto 2014).

Al principio del trabajo etnográfico, sólo era invitada a las reuniones semanales del sello que tenían lugar todos los miércoles -en lo que respecta al año 2011, ya que en 2012 se discontinuaron. En este contexto, a fines de agosto del año 2011, escribía en mi diario:

"Nicolás estaba en su computadora Mac y mechaba comentarios a propósito de lo que hablaban los demás (...) y también hacía preguntas técnicas al Pampa. De estas preguntas técnicas no pude captar mucho: es como si hubiera demasiados sobre-entendidos pero no sólo al respecto de estos 
aspectos técnicos sino de cuestiones que se hubieran hablado en otro momento (¿por chat?, ¿en encuentros casuales?, ¿encuentros de sub-grupos?). Según entiendo, la reunión semanal es a la que se me invita".

Los sobreentendidos se originaban sobre todo en las interacciones en las redes sociales virtuales. Ya en las primeras reuniones pude observar que en el sello trabajaban con distintas herramientas virtuales, especialmente Facebook y Google Drive. Al principio, no fui incluida en su grupo privado de Facebook ni en la carpeta "Concepto Cero" que tenían en Google Drive. Sin embargo, no pedí acceso personal -desde mi propio correo electrónico- a estos documentos y tampoco ellos me lo ofrecieron hasta varios meses después de comenzado el trabajo etnográfico. En el grupo de Facebook, al que fui incluida poco menos de un año después de empezar el trabajo, se solían organizar las reuniones, avisar de fechas o de campañas de promoción, compartir noticias sobre el mundo de la música, proponer ideas para el sello. Es decir, funcionaba como un grupo cerrado de "amigos" orientado a las cuestiones del sello. Mientras que en la carpeta de Drive a la que fui incluida en mi tercer año de campo -si bien ya me habían compartido documentos puntuales-, los chicos intercambiaban opiniones y tomaban decisiones sobre los eventos, terminaban de definir lo que se ponía en cada parte de un disco -tapa, contratapa, lomo, solapa interna, solapa externa-, escribían una gacetilla o una información de prensa, proyectaban presupuestos, armaban una grilla de trabajo, etc. El grupo de Facebook siempre fue más popular y entre sus integrantes incluía a los músicos de todas las bandas y a los fotógrafos. En cambio, el acceso a "el Drive” era mucho más restrictivo, por tratarse de cuestiones que hacían a la cocina de la gestión del sello en tanto tal. Durante el período, esta carpeta apenas fue compartida por no más de cinco personas, alternativamente las que tomaban las decisiones del sello. Cabe enfatizar que el carácter interactivo de la mayoría de estos espacios virtuales permite participar de la configuración virtual de las redes de sociabilidad de los actores, y por lo tanto son parte de la etnografía.

Esta información virtual, con la que conté durante una parte del trabajo de campo y del proceso de escritura, era en sí misma bastante fragmentaria y sólo pude entenderla en tanto era acompañada por mis interacciones en las redes de Concepto Cero durante todo el período. Así, por ejemplo, a partir de los documentos de Drive pude acceder a 
informaciones que, si bien había escuchado o había visto, no había podido retener -por ejemplo los presupuestos del sello-, pero estas sólo se volvían significativas en tanto las cruzaba con la lectura de mi diario. En este sentido, para la etnografía realizada la observación y la interacción con los músicos y productores estéticos domina y orienta la interpretación de todos los datos.

La misma relación de subordinación lógica con la observación participante tienen las entrevistas realizadas a los protagonistas de esta tesis. A fines del año 2010, cuando todavía no pensaba realizar una etnografía en Concepto Cero, entrevisté a Nicolás y a partir del segundo año de trabajo etnográfico realicé entrevistas personales abiertas y orientadas biográficamente (Alonso 1998) a algunos otros miembros de Concepto Cero y a los responsables de otros sellos musicales que conocí a partir de los emprendimientos del primero. Cabe aclarar que al hablar de "entrevista" refiero a una forma especial de encuentro, una conversación pautada y personal, para distinguirla del resto de las conversaciones. Con todos los entrevistados había compartido distintas escenas de la etnografía, había observado sus acciones y dichos, por lo que en las entrevistas, además de mínimas indagaciones dirigidas a reponer sus trayectos de vida, lo que tuvo lugar fueron interpretaciones cruzadas sobre hechos de los que ambos -entrevistadora y entrevistadohabíamos participado. La relación de campo actuó como mediación de las entrevistas, las cuales prolongaron la lógica de las interacciones y fueron interpretadas a la luz de esa interacción.

Por otro lado, es posible nuclear una serie de documentos por su carácter crucial para el mundo musical estudiado. Se trata del material periodístico y aficionado: entrevistas en programas de radio, revistas y blogs, tanto a los músicos en estudio como a otros con roles significativos; reseñas de discos o eventos en la prensa escrita; etc. El criterio que se tomó para seleccionar estos materiales, potencialmente enorme, proviene de la referencia por parte de mis interlocutores. Estas referencias son regulares, ya que para ellos la prensa, y en especial la prensa de rock, goza de un estatus privilegiado en la construcción de la música que producen. Se trata, por un lado, de la importancia de esta actividad periodística y crítica como multiplicadora del impacto de lo que ellos ya comunican en las redes sociales, como también de su papel en la construcción del valor de la música que se produce. A su vez, no deja de tratarse de un mundo donde el saber sobre bandas, discos, 
videoclips, recitales, aspectos de las biografías de artistas, funciona capitalizando a los músicos y por lo tanto es invocado a menudo. Nuevamente, el material -tanto el producido por el sello como el referenciado por sus miembros- recibió un tratamiento orientado por la observación participante. Es decir, estos materiales importan en tanto funcionan para volver más densa la comprensión de los significados que los músicos y productores estéticos juegan en su construcción del sello y de sus redes.

En mis registros realicé un ejercicio de extrañamiento que redundó en una extensión considerable del diario. Me impuse describir de manera detallada todo lo que recordaba de mis inmersiones pautadas -incluso lo que me parecía insignificante- de la manera menos interpretativa posible. Para ello convertí en máxima una frase de Howard Becker: "Decir que alguien parece tener prisa para llegar a su casa con la bolsa de las compras requiere una inferencia de motivaciones que decir que está caminando rápido no requiere" (Becker 2009: 109). Para recordar, hice uso de varias tácticas: tomaba nota en la interacción misma cuando a quienes acompañaba también lo hacían -por ejemplo en las reuniones de Concepto Cero, en las charlas o conferencias- y anotaba algunas palabras clave con el celular en las ocasiones en que tomar nota no era posible -básicamente durante todo el resto de las interacciones: los recitales, las fiestas, las jornadas de grabación, etc. Observar las profusas fotografías que el sello publicaba en las redes sociales también fue de utilidad para recordar los eventos públicos, aunque no realicé un análisis de las fotografías en sí mismas.

Asimismo, en el período de investigación, dada la plataforma cultural compartida ya señalada, combinada con las dimensiones del "cuadrado" platense, me encontraba a mis interlocutores sin pautarlo en el cine o el teatro, en recitales y fiestas no convocados por el sello, pero también en lugares como el colectivo o el supermercado. Registré estas interacciones cuando me parecieron significativas para mis objetivos, las cuales se fueron esclareciendo con el correr del mismo trabajo etnográfico. A su vez, continué participando de otras propuestas musicales y estéticas emergentes que tuvieron lugar durante el período, en La Plata, afines a las del sello elegido. La mayoría de estas experiencias no fueron parte de registros sistemáticos pero me dieron perspectiva sobre lo que observaba en la intimidad de Concepto Cero. Sin embargo, cuando alguno de estos emprendimientos irrumpía en las redes de Concepto Cero o empezaba a relacionarse con él, sí fueron registrados en mi diario 
etnográfico. De esta manera, y a modo de ejemplo, cuando Nicolás empezó a armarle fechas a la banda Mostruo lo acompañé a algunos recitales que le organizaba y comencé a relacionarme con sus músicos, para realizar luego los registros correspondientes. Ahora bien: no empecé a seguir a la banda como tal, sino que lo hacía desde la relación que esta tenía con el sello.

El trabajo etnográfico realizado entre los años 2011 y 2015 acompañó el despliegue de Concepto Cero como sello musical emergente: así, durante todo el año 2011 participé de reuniones periódicas de Concepto Cero, todos los miércoles a la mañana en un café céntrico de La Plata ${ }^{27}$. A ellas solíamos asistir entre seis y ocho personas y se trataban en común las tareas a realizar para los distintos eventos y proyectos en lo que estaba comprometido el sello. A su vez, asistí y colaboré de los ciclos mensuales de Concepto Cero, de los recitales de algunas bandas por él catalogadas y del evento que los mantuvo muy ocupados ese año: el lanzamiento y la presentación del disco "Los Ellos", un compilado en el que participaron dieciocho bandas y doce artistas visuales ${ }^{28}$. A lo largo del año 2012 las reuniones propias del sello se discontinuaron y el devenir de Concepto Cero como principal promotor de una red de sellos bonaerense -TICA $\operatorname{Red}^{29}$ - orientó mi trabajo hacia esa nueva red de relaciones, a partir de la cual pude, a su vez, establecer contactos con otros sellos de la provincia de Buenos Aires. Asimismo, la inclusión en ese año de TICA Red en un programa estatal de profesionalización de la música emergente -Recalculando ${ }^{30}$ coordinado por la entonces Secretaría de Cultura de la Nación ${ }^{31}$ con un criterio federal, me permitió ahondar más en el conocimiento de sellos, colectivos y artistas musicales de

\footnotetext{
${ }^{27}$ Esta locación fue sugerida por mí, a falta de lugares para el encuentro semanal, ya que por ese entonces la mayoría de los chicos vivían con sus padres.

${ }^{28}$ La producción de este disco inaugura mi trabajo de campo y será abordado en detalle en el capítulo II.

${ }^{29}$ Como será expuesto detalladamente en el capítulo III, TICA se conformó en el año 2012 en La Plata como una red de colectivos y sellos musicales de la provincia de Buenos Aires que se reconocían en las nociones de lo "independiente" y, luego también, de lo "emergente".

${ }^{30}$ Como desarrollo en el capítulo III, la constitución de TICA es relativamente posterior a la de Recalculando, un programa federal que tiene como objetivo explícito "acompañar en el desarrollo y la profesionalización a los sellos de gestión colectiva en el campo de la música emergente" (Folleto 2014). En la ciudad de La Plata, el programa recibió el entusiasmo de los sellos que se iban sumando a TICA, a la vez que TICA recogió el impulso del programa, específicamente de sus encuentros de capacitación, que convocaban a los músicos y los hacían entrar en contacto regular.

${ }^{31}$ Desde mayo de 2014, la Secretaría tiene rango de Ministerio, del cual ahora depende el programa, manteniendo su estructura de trabajo interna pero no la dependencia política directa.
} 
diferentes regiones del país ${ }^{32}$, a la vez que ponderar las relaciones con el Estado que practican estos colectivos. Desde el año 2013 y hasta la interrupción del trabajo de campo en el año 2015, continué participando en las reuniones y actividades que aparecían bajo el nombre de Concepto Cero y las que lo involucraban conjuntamente con sus amigos y aliados en la producción musical, como otros sellos, bandas, algunos dueños de bares y centros culturales, y funcionarios estatales del área de cultura.

Al seguir estos enlaces, me preguntaba hasta qué punto el sello movilizaba y activaba su red. Y más precisamente, hasta qué punto podría etnografiarlo. Como se verá en el capítulo III, seguí a Concepto Cero en TICA Red y a ambos en Recalculando porque los propios involucrados las privilegiaban en ese momento. No estudié ni la política pública ni la red en sí mismas, sino sus relaciones desde la posición de Concepto Cero. Otros vínculos y espacios activados por la red del sello no resultan objeto de análisis, más por la imposibilidad de abarcar en este trabajo todas las instancias de producción y gestión musical que por dificultades de acceso. Durante mi trabajo acompañé a mis interlocutores a estudios de grabación, que son parte operativa de la red. Sin embargo, no incluyo ni analizo esos materiales más que secundariamente. Lo mismo puede decirse de los lugares de presentación activados por el sello.

Quizás en compensación, posible gracias al abordaje etnográfico practicado, el devenir de la relación de este sello con otros de La Plata, la zona metropolitana de Buenos Aires y el resto del país -reuniones entre sellos, organización conjunta de fechas, proyecciones de redes de trabajo y otras actividades- me habilitó el conocimiento de otros sellos, lo que a partir de la comparación enriqueció el análisis y le dio perspectiva a la situación históricamente específica que analizo, la producción y gestión musical en Concepto Cero como sello musical emergente. En este marco, gracias a la disposición de mis interlocutores para integrarme en sus redes, me acerqué en particular a los siguientes sellos de La Plata: Dice Discos, Tomas del Mar Muerto y Uf Caruf ${ }^{33}$.

El recorrido etnográfico también acompañó los avatares de mi trayectoria académica y personal. Entre los años 2011 y 2012 escribí la mayor parte de las páginas del diario etnográfico. Mi participación en las redes del sello en ese período fue altamente

\footnotetext{
${ }^{32}$ Refiero a Córdoba, Mar del Plata, Rosario, Bariloche, Tucumán y Formosa, de acuerdo a la procedencia de los sellos con los que he tenido contacto en el trabajo de campo.

${ }^{33}$ Ampliaré sobre estos sellos en el capítulo III a partir de la descripción de la conformación de TICA Red.
} 
sistemática: en general, realizaba por lo menos dos inmersiones semanales con sus registros correspondientes. Pero a veces esta inmersión era sólo una, ninguna o tres o cuatro, dependiendo de las actividades que me proponían mis interlocutores o del hecho de encontrármelos en situaciones en las que no los esperaba. Durante los primeros seis meses del año 2013 discontinué mi participación para escribir mi tesis de maestría, que presenté en junio de ese mismo año, por lo que mi participación en el segundo semestre de ese año se regularizó. En los años 2014 y 2015 seguí realizando observaciones sistemáticas pero cada vez más seleccionadas, dado que empezar a dar clases de forma regular en la facultad acotó los tiempos que podía dedicar a la etnografía. Las observaciones de estos dos últimos años son más específicas y direccionadas en lo que ya veía como una tesis posible, a diferencia de las observaciones de los años anteriores donde me perdía en detalles que luego se revelaron no tan centrales para los objetivos de la tesis.

A partir de fines del 2014 empecé a experimentar cada encuentro o visita como si fuera la última observación, aquella que cerraría la tesis de manera perfecta, me atrevo a decir: coherente. Tales eran mis ganas que incluso les compartía esta idea a los músicos en el mismo transcurso de la interacción: "con esto cierro la tesis", les decía en cada evento que a todos se nos aparecía como importante. A razón de un relato de Cecilia Ferraudi, Pablo Semán llamó a esta situación "la epifanía del tesista", en un curso de etnografía en la Universidad de La Plata en el año 2015: el tesista sabe que tiene que terminar la tesis y vislumbra el cierre de un campo que él mismo ha construido. Lo que descubrí por la repetición de la sensación de supuestas escenas que cerrarían mi campo es que no había tal fin cerrado con moño para una investigadora expectante: termino esta tesis convencida de haber capturado como pude sólo un momento que no se agota en sí mismo, sino que tendré que cerrarlo yo misma, tal como lo abrí, por obra y gracia del trabajo etnográfico. Justamente, durante todo este tiempo, cada vez que encontraba a los músicos protagonistas de esta tesis volvía a casa a registrar lo que para mí eran nuevos y preciosos datos: no experimenté nunca la llamada saturación de la que hablan algunas corrientes metodológicas cualitativas (Piovani et al. 2012). Esto no se debía solamente al hecho de que la pregunta que había hecho a este mundo musical estaba históricamente abierta sino que la versión del método etnográfico que practicaba se fundaba en las cosas singulares. 
Velho (2015) advierte que el énfasis en las singularidades define a la etnografía como perspectiva de conocimiento y nos aleja de establecer demasiado rápido afinidades obvias que nos desvíen de vislumbrar las cosas con las que se pueden construir conexiones más ricas y necesarias. Dar cuenta positivamente de las formas de practicar, gestionar y experimentar la música en un contexto etnográfico singular fue el objetivo de la investigación realizada. En mi etnografía, las orientaciones de la sociología de las mediaciones otorgaron consistencia a dicha singularidad: me permitieron ver y trabajar las conexiones entre los sonidos, el sello, las tecnologías, los músicos, la ciudad, la profesionalización, como parte de un mismo proceso no acabado y en plena categorización. Hennion (2002) sugiere que la historia en tanto disciplina, que despliega las mediaciones pero no las conceptualiza como tales, ilumina esta forma de producir conocimiento para una sociología obsesionada con correr los velos de la dominación. En ese sentido, me permito decir que esta tesis realiza una historia del surgimiento de formas emergentes en la producción y gestión musical a partir del estudio del sello Concepto Cero, entre los años 2011 y 2105 . En esa historia, acompañar a los actores y seguirlos en sus recorridos y sus interpretaciones fue fundamental.

Como sostiene Ferraudi Curto (2014: 52), en una recuperación de los planteos de Marcio Goldman a propósito del estatuto de la política en distintos contextos etnográficos, no se trata de "captar el punto de vista del nativo" -como si este fuera uno o los grupos analizados fueran homogéneos- para contraponerlo con las teorías disciplinares -como si fueran dos polos antitéticos. Por el contrario, al asumir el conocimiento como proceso relacional, el objetivo es construir teoría etnográfica a partir del diálogo entre la etnógrafa, las teorías de las ciencias sociales y los sujetos con los que investigamos. Para mí, los músicos que protagonizan esta tesis fueron interlocutores de la etnografía en un sentido muy específico: traté de escribir hasta la última línea sin abandonar sus recorridos, su saber y su búsqueda reflexiva mientras estábamos en la música. 


\section{Capítulo II: Concepto Cero como sello musical gestionado entre amigos}

Ya promediando mi trabajo de campo, en el año 2013, conversábamos con Nicolás antes de que comenzara un evento, y repasaba yo las presentaciones públicas típicas de los sellos musicales con los que Concepto Cero se relacionaba al interior de la escena. En las presentaciones de los sellos para la prensa y los funcionarios estatales, en las entrevistas que hacían otros investigadores a sus participantes, los músicos y artistas repetían que su emprendimiento era un "grupo de amigos". Concepto Cero mismo solía plantear sus inicios de esa manera. Desde el año 2012, el hecho de compartir experiencias con los participantes de estos sellos había acompañado en la práctica este relato: cuando viajaba con ellos a la CABA para asistir a una capacitación organizada por la Secretaría de Cultura hacíamos bromas con "irnos de viaje a Bariloche", cuando algunos de los músicos me invitaban a su cumpleaños encontraba allí a los miembros de su sello -entre otros "amigos" de la escena-, cuando asistía a las reuniones de Concepto Cero me anoticiaba de la vida sentimental y familiar de los demás, a la vez que de los chistes internos que se propiciaban entre sí.

Sin embargo, ese día Nicolás replicó rápidamente con una mueca de cansancio: "Basta con esto del grupo de amigos". En una entrevista que le harían unos meses después para una revista online, Nicolás desarrollaba más esta idea: "Me cansé de escuchar la misma anécdota contada por un montón de gente diferente porque creo que es siempre igual. La idea surge de un grupo de amigos, de músicos, en base a ver la dificultad o la complicación que es insertarse en una escena. Creo que el rock tiene una cantidad de ejemplos en los que se puede ver cómo funciona y el sello es una figura en la que, en realidad, uno pone una marca en la cual agruparse y sacar los discos. Uno habla de sello y es un comodín para decir un montón de cosas"34.

¿Cuáles eran todas estas cosas en el caso de Concepto Cero? ¿Cómo se definía la amistad entre esas cosas? ¿Quiénes eran los amigos en la red de Concepto Cero? ¿Qué significaba en este contexto etnográfico ser amigos? ¿Qué diferencias en la manera de concebir el lazo y el sello musical se ponían en escena entre los distintos miembros del

\footnotetext{
34 "Uno habla de sello y es un comodín para decir un montón de cosas". Entrevista a Nicolás Madoery, Concepto Cero. Sin fecha, publicado en: http://www.elserviciopostal.com.ar/entrevistas/nicolasmadoery.html\#.UXApM6JLPrm (consultado: 18/04/2013)
} 
sello? En la línea de estos interrogantes, el objetivo de este capítulo es mostrar la primera configuración de Concepto Cero como sello musical emergente, en la que la producción y la gestión musical se resuelven al interior del grupo de amigos. Se tratará tanto de describir la unidad etnográfica de la tesis como de introducir las categorías de sujeto y de relación entre sujetos que la estructuran. Referiré así al concepto de sello y a la noción de amistad. En cuanto al sello, en diálogo con la bibliografía especializada se apuntará a evidenciar la falsa sinonimia que esta desarrolla entre la idea de sello musical y la de sello discográfico. A partir de estas lecturas y, siguiendo la perspectiva de los músicos, indagaré sobre el carácter de novedad de estos emprendimientos musicales. En cuanto a la categoría de amistad, la desarrollaré en sus matices: cuando a fines del año 2011 y principios del año 2012 diferentes miembros de Concepto Cero presentes desde los inicios decidan abandonar el proyecto lo harán desde la convicción de que había otras formas de entender y practicar este "grupo de amigos". Años después, Nicolás adjudicaría estos alejamientos a un "quiebre de profesionalización" desatado por la producción del disco Los Ellos. El intento de ser más profesionales tenía efectos en el grupo estable de músicos y artistas: ¿cómo se redefinía el lazo de amistad?

\section{"La misma anécdota contada por un montón de gente diferente que es siempre igual"}

Promediaba el año 2009 cuando Matías, Nicolás y El Tata conformaron Concepto Cero, si bien El Tata - de quien se hacían bromas constantes sobre lo "colgado" que era- ya estaba distanciado de ese papel central cuando inicié mi participación en las redes del sello en el año 2011, seguía participando de sus eventos y de algunos proyectos. Estos tres integrantes del núcleo duro del "grupo de amigos" operante en los comienzos del sello se habían conocido en las cursadas de la Licenciatura en composición con medios electroacústicos de la Universidad Nacional de Quilmes (UNQui). Mientras El Tata ya se había recibido cuando comencé el trabajo, Matías lo hizo a comienzos del año 2012, poco tiempo antes de que Nicolás, cada vez más abocado a sus actividades en el mundo musical, la abandonara. De acuerdo al relato de Nicolás, en estos comienzos los proyectos musicales de cada uno fueron determinantes para trazar las primeras redes del sello: Matías cantaba y tocaba la guitarra en Casimiro Roble, una banda de rock referenciada con la idea de power 
trío; Nicolás y el Tata hacían lo propio en Brahmán Cero, una banda de electrónica y rock industrial comandada por Nicolás; a la vez que El Tata tenía sus proyectos solistas, que el resto clasificaba de "experimentales". Los discos de estos tres proyectos inauguran de hecho el catálogo del sello ${ }^{35}$. En la entrevista en la que conocí personalmente a Nicolás, a fines del 2010, cuando el emprendimiento contaba un año y medio de funcionamiento, me contó: "Como que yo tuve la idea de que teníamos proyecto y de que quizás en la escena era complicado entrar y hacerse espacios y armar las fechas y todo. Entonces es como que tenía ganas de yo empezar a tocar con Matías en tal fecha juntos y, por otro lado, eso... ¿entendés? Pensar que, bueno, si vos tocás yo puedo estar en la taquilla, o yo puedo hacer la difusión".

A partir de una orientación de este tipo comenzaron a reunir a otros amigos, tanto músicos como artistas visuales. Compartían la idea de que un sello no podía pensarse sin "la parte gráfica y visual" por lo que se preocupaban por reclutar toda clase de artistas. Los primeros de estos amigos fueron los propios compañeros de banda: Cristóbal, bajista de Casimiro Roble; Nicolás Reyes, bajista de Brahmán Cero; Mariano y Tadeo, ilustradores que se encargaban de las proyecciones visuales que completaban, en vivo, la música de Brahmán Cero. Más adelante se sumaron otros amigos y amigas, cuyo promedio de edad rondaba los 23 años, la mayoría de los cuales habían transitado las aulas del "Bachi"36, el Bachillerato de Bellas Artes de la UNLP y ahora estudiaban en carreras de la Facultad de Bellas Artes de la UNLP y de la Universidad Nacional de Quilmes (UNQui).

En el año 2011, cuando comencé a participar sistemáticamente de los espacios que Nicolás y Matías me habilitaban, Concepto Cero había editado seis discos: "Dueño no tengo" y "Búcaro de Tata Laxague", Volumen I y Volumen II de Casimiro Roble; "Realidad/Ansiedad" de Brahmán Cero; y "Música total” de Excursiones Polares. Asimismo, el grupo de amigos se encontraba preparando el lanzamiento del disco "Los Ellos”, un homenaje a la historieta El Eternauta, cuyo proceso de producción, fabricación, presentación y venta desarrollaré al final de este capítulo. Tal como atestiguan la página de Facebook del sello y los documentos internos a los que pude acceder, bajo el nombre de

\footnotetext{
${ }^{35}$ Se trata de los discos "Volumen 1", de Casimiro Roble; "Realidad /Ansiedad", de Brahmán Cero; "Dueño no tengo" y "Búcaro", de Tata Laxague.

${ }^{36}$ El "Bachi" es un establecimiento de educación secundaria especializado en arte, donde además de la formación general se brinda formación específica en artes, en dos orientaciones a elegir por el alumno: música $\mathrm{o}$ artes visuales.
} 
Concepto Cero se realizaron dos eventos de diferente tipo durante los años 2009 y 2010: las fiestas GudCresiGud y el Ciclo Concepto Cero. Las fiestas combinaban bandas y DJ's luego de la medianoche, y se realizaban de manera itinerante: en espacios culturales como Tahuma - un lugar que me presentaron como "el centro cultural del Tata", donde también se encontraba su vivienda- y el Centro Cultural Favero o en bares como Pura Vida, lugar donde también se realizó la primera fiesta aniversario del sello, evento que seguirían realizando todos los años en otros espacios de la ciudad como el Galpón del grupo La Grieta $(2011,2012)$ y C'est la vie $(2015)^{37}$.

Por su parte, el ciclo del hostel Frankville ${ }^{38}$-que se realizó regularmente durante los años 2011 y 2012 de mi trabajo de campo, con algunas ediciones en el año 2013- era un ciclo mensual de música en vivo en formato acústico, a cargo de un solista y una banda, acompañados de una muestra de artes visuales o fotografía, a partir de las ocho de la noche. Este evento regular reunía a jóvenes habitantes de La Plata con los extranjeros que se hospedaban en el hostel. Dadas las características del espacio, nunca terminaba tarde: "tipo dos se empieza a levantar campamento", decían los chicos sobre el ciclo en el que se la pasaban entre chistes y cervezas. El arreglo con el dueño del lugar, a quien consideraban amigo, incluía publicidad del hostel en los eventos del sello a cambio del local. El hostel ganaba con la barra y el sello con "la puerta", es decir, con la venta de entradas -que no corrían para los huéspedes. Pero la relación con el hostel excedía el evento: el dueño los invitaba a su cumpleaños y participaba de los eventos, prestaba el hostel para reuniones del sello -en particular esta opción fue aprovechada en el año 2012- y para cumpleaños de sus miembros -ese mismo año festejamos allí el de Nicolás. Asimismo, existía otro acuerdo con el hostel que involucraba disponer de plazas para los integrantes de bandas invitadas por el sello a tocar en La Plata, siempre a cambio de publicidad.

Los arreglos no terminaban ahí: el ciclo de Frankville era auspiciado por la cerveza artesanal local "Cabra 52" bajo el contrato de proveer de cierta cantidad gratuita de cervezas a los organizadores, sus amigos y las bandas que tocaban esa noche, a cambio de publicidad en todos los eventos del sello. Como decía Nicolás jocosamente en esos

\footnotetext{
${ }^{37}$ La fiesta del 2013 planificada en La Trastienda Club de La Plata fue suspendida a último momento luego de las trágicas inundaciones que asolaron la ciudad. En el año 2014, por cumplirse cinco años del sello, se realizaron una serie de acciones durante todo el año bajo el slogan "Concepto Cinco".

${ }^{38}$ Se trata de un hostel orientado al turismo joven internacional, como suele suceder en este rubro, ubicado en la calle 46, entre las calles 10 y 11 , a pocos metros de la diagonal 74.
} 
contextos nocturnos: "Lo mejor de tener un sello es el arreglo con la cerveza". El sello multiplicaba lo más posible la figura de los auspiciantes: estudios de grabación, fanzines y revistas culturales, productoras de cine, entre otras emprendimientos y pequeñas empresas de "amigos", participaban de alguna manera en los eventos organizados bajo su rúbrica. Estos vínculos no eran para nada usuales en las fechas gestionadas por las bandas y sellos independientes en el período de mi investigación anterior (2009-2011), y si bien crecieron en los años en que me relacioné con Concepto Cero, no llegaron a ser un denominador común.

Por último, el grupo de Concepto Cero tenía experiencia en la producción de distintos eventos para terceros: entre otros, el FESAALP -Festival Latinoamericano de Cine de La Plata- ${ }^{39}$ y el TRImarchi ${ }^{40}$ los habían elegido para organizar fiestas, inauguraciones y recitales al interior de sus proyectos entre los años 2010 y 2011. Producir eventos para terceros los diferenciaba de otros sellos musicales de amigos de La Plata, y hacía oscilar en estos contextos su definición de sello hacia la de "sello/productora independiente", como se podía leer en las presentaciones del sello presentes en los folletos que repartían en esos mismos eventos. Como se podrá apreciar más adelante en este capítulo, esta característica producía tensiones al interior del grupo de amigos: en los sellos de amigos se produce música para un circuito más o menos establecido, conocido y manejable de personas, excepción hecha del caso de bandas que se consagran por fuera del circuito, atrayendo nuevos públicos. Por el contrario, cuando un sello empieza a hacer eventos para terceros o planea eventos de gran porte aparecen problemas novedosos de gestión y control, especialmente del público.

\section{Los integrantes de la "crew"}

Como adelanté, había otras personas implicadas en la que llamaban la "crew" además de los socios. En las reuniones en las que nos encontramos durante el 2011 -todos

\footnotetext{
${ }^{39}$ Se trata de un festival de cine que se realiza en la ciudad de La Plata desde el año 2006 y hoy cuenta con 10 años de trayectoria. Desde sus orígenes a la actualidad es impulsado por la Facultad de Periodismo y Comunicación Social de la UNLP.

${ }^{40}$ Refiere a un encuentro internacional de diseño con sede en la ciudad de Mar del Plata, creado por Seba Acampante y Pablo Pacheco cuando eran estudiantes de diseño. Ambos participaron como ilustradores del proyecto "Los Ellos" y continuaron sus participaciones en otros emprendimientos del sello.
} 
los miércoles a las 10 de la mañana en una cafetería céntrica ${ }^{41}$ - participaban de forma regular Cristóbal, Tadeo, Melina, El Pampa y Mariano. Si bien no solían participar de las reuniones del sello, los fotógrafos también formaban parte de esta red, como también algunos amigos artistas que colaboraban con el emprendimiento

Cuando lo conocí, a los 23 años, Nicolás ya había trabajado en varios boliches de Capital Federal, orientados a los eventos en vivo de rock y electrónica dance como Niceto y Cocoliche. También había hecho lo propio para un sello: "Era el che pibe", me explicó, "pero bueno, eso te da una idea de cómo se manejan algunas cuestiones que, si no, quizás no las sabés". Estaba también tocando con su banda Brahmán Cero, en la que se encargaba de la voz y de las programaciones. Podríamos decir que para Nicolás la música era parte de su vida desde temprana edad: había hecho la secundaria en el "Bachi" -aunque orientado a las artes visuales- y su padre era músico, musicólogo y profesor-investigador en la Facultad de Bellas Artes de la UNLP. Nicolás era reconocidamente muy dado para las relaciones interpersonales y siempre lo encontraba conversando con distintas personas en los eventos -casi siempre acerca de trabajos del sello. Esa era una de las diferencias que Nicolás veía con Matías: "Mati no es un tipo de eventos, no le gustan estas cosas", me dijo en una ocasión en la que estábamos en la inauguración de un festival de cine organizada por Concepto Cero y no encontrábamos en ningún lugar a su compañero. Por el contrario, Nicolás siempre estaba en el centro de la escena y, entre la variedad de actividades que el sello requería, prefería la del contacto con las bandas y los artistas, las estrategias comunicacionales del sello, hablar con la prensa y manejar las redes sociales.

Por su parte, Matías estaba por cumplir 30 años. Había venido desde una pequeña ciudad entrerriana para estudiar en La Plata. Era la voz y el guitarrista de Casimiro Roble. Cuando lo conocí, estaba en pareja estable con una estudiante de violín y piano que tenía un proyecto de música para películas. Se querían mudar juntos y vendían dulces caseros para juntar dinero. Matías era "el crack en cuestiones de sonido", como lo definió alguna vez Nicolás, y siempre se encargaba de la técnica del sonido de los distintos eventos del sello. También realizaba actividades de gestión y comunicación junto a Nicolás, pero lo suyo era

\footnotetext{
${ }^{41}$ El bar del Pasaje Dardo Rocha, en la esquina de las calles 6 y 49, locación sugerida por mí ya que la mayoría de los chicos del sello vivían con los padres. En el año 2012 y 2013 las reuniones pasaron a realizarse en el hostel Frankville, el bar del Pasaje y otros bares. Apenas entrado el año 2014, Nicolás se mudó a un departamento y las reuniones comenzaron a hacerse allí.
} 
el estudio de grabación. Como pude comprobar al asistir a recitales con él, era un músico y oyente obsesivo, atento a cada mínimo detalle de lo que ocurría en una canción. Matías tenía montado en ese momento un estudio casero de grabación en una de las habitaciones del $\mathrm{pH}$ que alquilaba frente a la terminal de ómnibus al que había bautizado La Pieza. Grababa y mezclaba la música de grupos vinculados al sello, pero también de otros proyectos que ni él ni Nicolás planeaban incorporar al catálogo.

Cristóbal tenía la misma edad que Nicolás cuando lo conocí. Había nacido en La Plata pero crecido en Trenque Lauquen y San Miguel de Tucumán, ciudad de la que se desplazó para estudiar cine en el Instituto Universitario Nacional de Arte (IUNA), para luego retomarla en La Plata, carrera que iba llevando y abandonando según el momento en que una se lo cruzara. Había estudiado música desde niño por intermedio de su padre músico, docente de música y director de orquestas y coro: “A mí me gustaba el rock y él me inscribía en el conservatorio a trompeta o flautín no sé cuánto”, me dijo en una entrevista. Cristo se desempeñaba como bajista en Casimiro Roble y era muy amigo de Matías: cuando este vivía en la zona de la terminal pasaba mucho tiempo en su casa, y a mediados del año 2011 se mudaron juntos a un nuevo departamento. Asimismo, cuando lo conocí comenzaba a encomendarse en algunas tareas de producción del sello. Cristo decía que estas tareas le gustaban porque tenían relación con el cine: planificar los lugares, el sonido, las luces, la taquilla y todos los elementos necesarios para que el evento salga bien.

Tadeo y Mariano participaban desde los comienzos en el sello y se encargaban del montaje de muestras propias y de otros artistas en sus eventos, por ejemplo en el Ciclo Concepto Cero llevado a cabo en el hostel Frankville. Además, ambos tenían a su cargo por entonces las visuales de Brahmán Cero -la banda de Nicolás- que se procesaban en tiempo real, es decir, mientras la banda estaba tocando. Ambos estudiaban artes plásticas en la Facultad de Bellas Artes. Tadeo es ilustrador y, desde que lo conozco, se ha relacionado con ciertos artistas del mundo de la música emergente de La Plata y de la CABA. Solía publicar ilustraciones en revistas del ambiente, además de promocionarlas en su blog y en Facebook, participar de fanzines y realizar flyers para muchos artistas, que aunque no pertenecieran a Concepto Cero transitaban la misma escena: Violeta Castillo, Villa Diamante, Sara Hebe, Marina Fages y Shaman ${ }^{42}$. En una de las primeras reuniones, me

\footnotetext{
${ }^{42}$ Algunos de estos artistas luego comenzarían a trabajar con Concepto Cero.
} 
enteré que también tenía una banda con Mariano, el otro ilustrador. Esta banda, llamada "La máquina de hacer chorizos", se definía desde las referencias al punk y, para mi sorpresa e incomprensión -que retomaré en el último capítulo de esta tesis-, no se encontraba en el catálogo de Concepto Cero. Por su parte, Mariano producía sus propios fanzines y tenía un blog donde conjugaba sus producciones en la ilustración, la poesía y la música. Tadeo y Mariano conformaban el equipo de diseño del sello junto a Emmanuel, a quien llamaban El Pampa por haber nacido en la provincia homónima. En el año 2005, El Pampa había venido a estudiar Diseño en Comunicación Visual a la UNLP, orientándose hacia la ilustración y el collage digital como también al diseño editorial y publicitario. A diferencia de Mariano y Tadeo, se había integrado a Concepto Cero en el año 2011, prácticamente dos años después de los inicios de la actividad.

Mariano, Tadeo y El Pampa se encargaban en aquel momento de la "gráfica" e "imagen" de Concepto Cero. En los términos de las reuniones semanales conformaban el "grupo de diseñadores": de hecho, eran una especie de sub-grupo que compartía cierta circulación en el mundo de las artes visuales platenses, además de códigos que los demás no manejábamos del todo, debido a sus actividades estéticas específicas -ijamás pude retener la terminología técnica: tipos y gramajes de papeles, tintas, etc., que sacaban a relucir naturalmente en los encuentros!. Con un pie adentro y otro afuera de este grupo estaba Melina, recién ingresada a la Universidad, donde continuaba sus estudios en artes visuales, a los que ya se había orientado realizando el secundario en el Bachi. Se había unido al sello luego de un año de ser una habitué de sus eventos durante el 2010. La intención de Nicolás había sido invitarla para que aprendiera y se sumara a las actividades del sello, de producción especialmente. Durante el 2011 participó de todas las reuniones semanales del sello, a la vez que se encargó de montar una muestra de dibujos en una edición del ciclo del hostel.

Había otros dos miembros ocupados en cuestiones visuales, específicamente en la fotografía. Cata y Pancho eran "los fotógrafos de Concepto Cero" por entonces. Ninguno de los dos asistía a estas reuniones pero sí se reunían regularmente con Matías y Nicolás en varias ocasiones los veía llegar a la casa de Nicolás después de una visita mía-, además de asistir a cubrir los eventos del sello. Cata tenía una relación de amistad emocional muy cercana con Nicolás, cimentada desde la escuela secundaria, mientras que Pancho era el 
hermano del Tata, a quien Nicolás y Matías consideraban tan “colgado” como él. Quizás por ese motivo, Pancho no solía estar presente en mis encuentros con sus compañeros y no desarrollé a lo largo del trabajo un vínculo con él. Por su parte, Cata se dedicaba a la fotografía de forma muy activa: exponía en los eventos del sello, solía participar de muestras fotográficas en la ciudad, a la vez que trataba de vivir económicamente de la fotografía tanto en el mundo musical como fuera de él. Aún más, solía tomar trabajos de fotógrafa relegando su propio placer estético. En un evento se retiró antes y me dijo: "Yo ya me voy, me voy a sacar fotos a un cumpleaños infantil”, ironizando con que allí encontraba su "verdadera pasión” para luego agregar "es un bajón, pero es guita".

Otros artistas eran considerados parte de la "crew" pero su participación era más acotada y puntual, dedicada a proyectos específicos, por lo que tampoco asistían a las reuniones. Uno de ellos era el hermano de Matías, Julián, quien tenía una incipiente productora de cine -Pi Producciones- y en muchas de mis visitas a la casa de Matías lo encontraba editando videos en el living comedor, en algunas ocasiones vinculados a Concepto Cero. También Julián pasaba algún que otro cortometraje de su autoría en los eventos del sello. Otra era Corina, profesora de plástica recibida en la Facultad de Bellas Artes, artista visual y encargada de la estética del primer disco de Excursiones Polares en Concepto Cero.

En cuanto a la composición de la "crew", Nicolás y Matías compartían conmigo sus expectativas de sumar nuevos integrantes plenos. Por entonces en algunos elementos de folletería y de comunicación web incluían la siguiente leyenda: "Contactate con nosotros. Queremos generar nuevos lazos, sumar nuevos artistas y gente al equipo". En especial, estaban en la búsqueda de personas interesadas en la producción, "la parte chota de la música", como decía Cristóbal, quien se dedicaba a ella; o la parte "piedra", como decía Tadeo, que la detestaba. Matías y Nicolás me repetían que era muy difícil reclutar personas que se quisieran dedicar a estas actividades. Durante el período de trabajo etnográfico la búsqueda fue permanente y sumarían varias personas para la producción, la gestión y la comunicación, aunque estos arreglos nunca lograban suficiente estabilidad, tal como desarrollaré en el capítulo IV.

No existían preferencias de género para este reclutamiento, aunque en consonancia con el resto de la escena hacia el año 2011, en Concepto Cero el predominio era de los 
varones. Entre nosotros, al principio se encontraban tres mujeres: Cata, la fotógrafa; Corina, la artista visual; y Melina, otra artista visual que aprendía el oficio de productora. Además de que los varones predominan en la mayoría de las actividades, solían protagonizar las más visibles y jerarquizadas, ya sea arriba como abajo del escenario. Las mujeres solían asumir tareas tras bambalinas - especialmente fotografía, escenografía, diseño y cobro de entradas, discos y otros productos que puedan ofrecerse en los eventos- y no era inusual que se encontraran vinculadas sentimentalmente a algún miembro masculino de la red, si bien no era el caso en Concepto Cero. No obstante, en un sello musical que declaraba abiertamente que la fotografía, el diseño y otras prácticas estéticas tenían tanta relevancia como la música en escena, las mujeres y sus prácticas se volvían más visibles e imprescindibles. A lo largo del período, por otra parte, varias mujeres músicas entraron al catálogo, lo cual será desarrollado en el capítulo V.

Mis interlocutores presentaban una procedencia geográfica y económica heterogénea: algunos habían crecido en el casco urbano de La Plata, otros en localidades dentro del partido de La Plata como Gonnet o City Bell, mientras un tercer grupo se había instalado en la ciudad desde centros urbanos del interior del país. La composición de clase no resultaba homogénea pero todos habían cursado sus estudios secundarios en alguno de los colegios dependientes de la UNLP o bien estaban haciendo lo propio en alguna carrera universitaria de la misma institución. Curiosamente, exhibían trayectorias escolares muy similares a los músicos con los que había hecho trabajo de campo durante el período comprendido entre fines del año 2009 y principios del año 2011. Los integrantes de Concepto Cero eran entre cinco y diez años menores en edad a estos últimos pero habían ido a los mismos colegios pre-universitarios y compartían con mis viejos "nativos" -tal como los llamaba irónicamente- ciertas pautas culturales asociadas a las clases medias. Unos y otros habían estudiado en escuelas con una fuerte presencia de padres profesionales y empleados de diferentes esferas de la actividad económica, que valoran la tradición de la escuela pública y la formación ilustrada, a la vez que entienden la educación como estrategia familiar de ascenso social (Ziegler 2007) ${ }^{43}$. Pero entre ellos se encontraban

\footnotetext{
${ }^{43}$ El hecho de que, desde la restauración democrática, el ingreso a los colegios dependientes de la Universidad de La Plata no sea por exámenes sino por sorteo matiza en parte el reclutamiento socialmente endogámico, no obstante lo cual, y aún reconociendo las experiencias heterogéneas de estos colegios, se encuentra una pauta cultural asociada a las clases medias.
} 
quienes, como Tadeo, se relacionaban con la música de una manera más "relajada", bastante parecida con las que me había familiarizado en mi investigación anterior -iquizás porque la pasión de Tadeo estaba en las artes visuales!- y quienes, como Matías y Nicolás, me proponían contrastes con ella.

Por más que todavía no pudiera definir el vínculo con la música y el trabajo musical de quienes se convertirían en mis interlocutores principales -Cristóbal, Matías, Nicolásera claro que la categoría de lo relajado no hacía sentido aquí: el minimalismo de la ambición típico de las disposiciones relajadas, entendido como una forma en que mis anteriores entrevistados renegaban de darse importancia -ser conscientes de sus límites, despreciar el ansia de figuración, rechazar las ambiciones desmedidas, burlarse de lo "pretencioso"- los mostraba suspicaces con respecto a las retóricas y las prácticas profesionales $^{44}$. Justamente eran ellas las que Concepto Cero intentaba desplegar.

Podría decirse que ser profesionales no estaba en el horizonte de las bandas indies entre los años 2009 y 2011, y la alergia a dicha noción, asociada a actitudes "caretas" era tal que cuando hablaban de ciertas salidas de una posición que entendían amateur -en su caso editar discos caseros en CD-R- decían que se habían vuelto más "prolijos"45. Asimismo, existía una marca del orden de lo relajado que hacía que la expectativa monetaria para estas actividades musicales fuera alcanzar la sustentabilidad más que ganar dinero: una situación, como resumía uno de aquellos músicos, en la que "si no ganás, al menos no perdés" y "si da ganancias, da ganancias". En este sentido, se tendía fuertemente a la coexistencia o complementariedad con otras actividades fuera de la música. En contraste, Cristóbal, Nicolás y Matías esperaban poder "vivir de la música", es decir, obtener el sustento a partir de prácticas musicales y abandonar la perspectiva de dichas actividades complementarias.

\footnotetext{
44 Estas perspectivas sencillas para la propia trayectoria musical constituían una manera de construir la autenticidad de la música para el caso del indie platense, estudiado en el período 2009/2011.

${ }^{45}$ En este sentido, el cantante de una banda del Conurbano que compartía el circuito indie de La Plata en el período 2009-2011 operaba un desplazamiento (y se "atajaba") al decir: "Yo siempre tuve claro que, en cuestión sonora, Viva elástico no era una banda indie, porque aunque suene medio careta lo que voy a decir, a mí me gusta mucho el sonido hi fi. Y no te hablo de grabar en Abbey Road o de masterizar con un capo en Nueva York... Me refiero simplemente a hacer las cosas a partir de otra búsqueda, con una mirada diferente. Me interesa sonar más claro, dentro de lo que se puede". En: "Cuestión de Actitud. Entrevista a Viva Elástico", Revista Los Inrockuptibles. Recuperado de: http:/www.losinrocks.com/wp-content/uploads/2010/07/velastico-abr10.pdf
} 


\section{Redes de amigos y tecnologías}

Además de congregar a un grupo de personas que cruzaban y complementaban sus distintas orientaciones estéticas, Concepto Cero reunía a un grupo de amigos. Este grupo se había formado a partir de compañeros actuales de la facultad-Matías, Tata y Nicolás, por un lado; Mariano, Tadeo, Pampa y Melina, por el otro- y ex compañeros de colegio Nicolás, Tadeo y Cata- que compartían los avatares de esas instancias académicas y de sus vidas estudiantiles. Así, en las reuniones del sello el grupo de "diseñadores" intercambiaba diálogos sobre las entregas que tenían para las distintas materias y sobre el carácter de los docentes, a la vez que Matías daba cuenta de los problemas para realizar su tesis.

Otros temas relacionados a la práctica artística tenían lugar en las reuniones: Tadeo solía contar acerca de los trabajos de ilustración que conseguía en publicaciones impresas independientes del mundo del arte y de la música, además de su orgullo por los músicos que le gustaban y lo contactaban para pedirle un flyer; Matías nos actualizaba sobre las bandas que grababa y/o mezclaba en su estudio y Nicolás relataba los cambios de baterista de su banda y su imposibilidad de ensayar. Pero además de intervenciones de ese tipo, en las reuniones podíamos enterarnos sobre las nuevas zapatillas que se había comprado Nicolás, fan declarado de algunos modelos de Nike, y de las chicas que le gustaban a Tadeo. Dadas estas complicidades, a lo largo del primer año de trabajo etnográfico era usual que me encontrara a algunos de los miembros de Concepto Cero en fiestas y recitales que no organizaba el sello y en las reuniones de los miércoles ciertamente referían a sus salidas en común explicitando quien "no podía hacer pie" y quien "ni manejar". Ese mismo año, los asistentes a estas reuniones -El Pampa, Tadeo, Mariano, Cristóbal, Melina, Matías y Nicolás- viajaron juntos al Congreso de Diseño TriMarchi DG en Mar del Plata. Si bien fueron a trabajar para el sello en la organización de recitales y en la presentación del disco "Los Ellos", volvieron con un inventario de anécdotas propio de un viaje de egresados.

Cuando me impliqué con otros sellos musicales de La Plata de la mano de Concepto Cero pude comprobar que, en un contexto de fuerte agenciamiento tecnológico, funcionaban a partir de la comunión de los esfuerzos de cada amigo. Cada uno de ellos aportaba algo que el sello necesitaba y que respondía a su competencia artística más reconocida en ese mundo artístico, ya que las competencias estéticas de estos amigos, por 
lo general, son múltiples: composición, producción, grabación, mezcla, diseño, video, fotografía, luces, escenografía, etc. Por otro lado, el "grupo de amigos" era la referencia para relatar y conceptualizar la propia historia de vínculo con la música. Cuando Lucio, de Dice Discos, me contaba la historia del sello y de las relaciones entre sus integrantes, realizaba conexiones entre la práctica de "andar en skate" por el barrio y compartir profesores de instrumento, situándose por lo menos diez años atrás. De la misma manera, en mi investigación anterior había visto cómo un sello indie de la ciudad se había conformado alrededor del año 2004 a partir de darle un nombre a un grupo de artistas que ya compartía actividades -no sólo estéticas- al menos desde comienzos de la década: bandas que se armaban y desarmaban a un ritmo frenético, fechas, fanzines, pero también asados, veladas de lectura, salidas nocturnas, reuniones para "jugar a la play", viajes de vacaciones (Boix 2013).

La red no sólo proveía de la capacidad de trabajo de los distintos amigos sino de recursos financieros, materiales y tecnológicos. En cuanto al dinero, hasta llegar a situaciones de sustentabilidad donde el sello pudiera invertir lo que ganara, era necesario realizar préstamos y derivar recursos al sello, comprometiendo la economía propia. Compartir estos gastos con un grupo amplio de amigos permitía llevar adelante el proyecto incluso cuando pudiese ir "a pérdida", como veremos específicamente en el caso del disco “Los Ellos”. Por otro lado, con recursos materiales refiero especialmente a espacios físicos propios de la red o que puedan activarse a partir de ella, clave para no depender totalmente de los denominados "bolicheros", quienes desde la perspectiva de los músicos de Concepto Cero no solían formar parte de una red posible. La mayoría era, según la síntesis de un músico y periodista de la escena al que entrevisté, "usureros" y "saqueadores de bandas" que exigían "pagar para tocar" 46 . Hasta bien entrado el año 2011, Concepto Cero realizó fechas en Tahuma, el centro cultural del Tata. Además, el sello ejercía una política activa de incorporación de los lugares a la red, tal es el ejemplo de sus arreglos con el hostel, así

\footnotetext{
${ }^{46}$ Esta práctica resultaba inaceptable no sólo por una cuestión económica, teniendo en cuenta que un buen arreglo con el propietario del local da ganancias que permiten seguir produciendo, sino también por una cuestión de honor -tal como desarrollo ampliamente en: Boix 2013. En este contexto, tanto para Concepto Cero como para sus sellos amigos, el bar Pura Vida se erigía en uno de los espacios favoritos y en uno de los pocos en la ciudad que era manejado por personas "del palo" y que no cobraba por tocar. Como me dijo el cantante de una banda: "Es un lugar donde te dejan tocar, no te cobran plata, te dejan encima la plata de la puerta y te dan cerveza además. El dueño es un genio...". Concepto Cero también realizaba eventos y fechas en otros lugares que respetaban esta pauta: Centro Cultural Favero, el galpón de La Grieta y la sala Tupé -hoy inexistente-, entre otros.
} 
como más adelante lo hizo con la casa cultural C'est la vie, donde co-gestionaron una serie de ciclos de recitales ${ }^{47}$.

Párrafo aparte merecen las tecnologías digitales y musicales que resultaban omnipresentes y definitorias para el trabajo de la red. Además de los encuentros en cafeterías y en sus casas, los participantes producían para el sello siempre conectados a Internet: terminaban de definir detalles de los eventos en una 'skypeada' -una teleconferencia por Skype-, armaban presupuestos en archivos compartidos de Google Drive, combinaban encuentros por Facebook y Twitter, realizaban propuestas para el sello en grupos privados de Facebook, etc. Al estar interesados por el trabajo en la música y el arte, los amigos tendían a equiparse y ponían a disposición del grupo estas tecnologías. Además de que todos contaban con instrumentos y equipos de amplificación que se podían prestar entre sí, Nicolás tenía varios dispositivos electrónicos para pasar y producir música; Tadeo contaba con una máquina para serigrafía en la que se hicieron remeras del sello, además de otros recursos de impresión; Matías era dueño de micrófonos, una consola y otros equipos de sonido, además de softwares multipista de audio; Cristóbal estaba equipado con cámaras filmadoras, mientras Cata y Pancho con cámaras fotográficas profesionales. Estas adquisiciones provenían sobre todo de regalos, préstamos e inversiones de la familia de cada uno de los integrantes.

En este contexto, la interdisciplinariedad tan afirmada para ciertas músicas jóvenes y rockeras de La Plata (Jalil 2000, Rodríguez Alzueta 2005, Doeswijk y Ruiz 2007, Zabiuk 2009, Vicentini 2010) debe entenderse en relación a la situación ecológica que confiere la red del sello y las redes universitarias y artísticas más amplias con las que se relaciona. La interdisciplinariedad en este caso es el resultado naturalizado de convivencias dilatadas en diversos ámbitos - las casas, las aulas, los centros culturales, las plazas, las fiestas, etc.donde los intercambios entre jóvenes que se dedican a diferentes disciplinas artísticas son la regla.

\footnotetext{
${ }^{47}$ Esta política de incorporación de los lugares a la red empezó a habilitarse al término del trabajo etnográfico para la mayoría de los sellos musicales con los que Concepto Cero se relacionaba. En la multiplicación de espacios y "casas" culturales a cargo de jóvenes radicados en la ciudad, temporalmente posterior a la de los sellos musicales, estos músicos encontraron nuevos amigos. Sitios como Casa C'est la vie, Librería y Galería Siberia, Club Galería Cösmiko, Casa Pulsar, Casa Animal, entre otras, pudieron ser incorporados a la red ya que se guardaban afinidades en las formas de trabajo. Algunas de estas propuestas, como Siberia y Cösmiko habían nacido al calor del interés por la exposición de jóvenes artistas visuales (López 2013); y otras, como Casa Pulsar y C'est la vie, estaban más vinculadas con el mundo de la gestión cultural.
} 
El carácter amical de la red de Concepto Cero en tanto sello me resultó fácil de captar a la vez que difícil de conceptualizar. En las primeras notas registro cuestiones como las anteriormente referidas con la sospecha de que lo hacía en vano y que no tendrían utilidad en una etnografía sobre un sello musical. Así es como en los registros puedo apreciar que durante las conversaciones de los miércoles "se mezclaban cuestiones específicas de qué iban a hacer en la presentación del disco con cuestiones de hotelería y bromas sobre El Tata" o afirmar que "en cuanto a los temas más específicos de la labor del sello hablaron de algunas cosas de Mar del Plata (Trimarchi)". Si bien ya había realizado un trabajo de investigación con otro sello musical de La Plata y había notado la importancia de la amistad (Boix 2011), seguía imbuida de la idea de sentido común social y sociológico de sello y no terminaba de comprender la especificidad del vínculo amical que se jugaba en estas redes estéticas.

Efectivamente, al inicio del trabajo me preguntaba por la especificidad de los “temas" y las actividades del sello sin percibir que, por ejemplo, las conversaciones sobre la nueva chica de la que gustaba a Tadeo era un tema del sello en tanto esa chica había sido invitada a participar con una obra para un proyecto. En este punto, mi incomprensión podría entenderse no sólo por la fuerza del sentido común sobre los sellos musicales, sino en la constatación de que la idea de que existían temáticas y competencias "específicas" del sello, que correspondían al ámbito de la reunión, era compartida por momentos por Nicolás, interlocutor fundamental de mi trabajo. Sus motivos eran diferentes: preocupado por resolver eventos o proyectos no quería "perder tiempo" en transacciones y conversaciones accesorias. En este sentido, cuando en una ocasión Matías vendía dulces caseros en la reunión, Tadeo y Melina le compraban durante su transcurso y Tadeo le comentaba sobre los muchos frascos vacíos que le había conseguido en una oficina, Nicolás acotó seriamente: "esto es la reunión, todas esas cosas las podemos hablar después". Momentos de tensión como ese se hicieron más comunes a medida que avanzaba el año 2011 y nos aproximábamos al lanzamiento del disco "Los Ellos”. En ese contexto, registré:

Como siempre, sale de Nicolás una moción de orden cuando los otros se dispersan, “¿nos concentramos en la reunión así nos vamos antes?”, dice. Tadeo le responde en joda: “todos 
nos queremos ir antes, qué te pensás. A mí me esperan en esa reunión de ahí atrás”, mientras señala con la mirada a una reunión de tipos trajeados.

Lo que se tensionaba eran las prerrogativas del trabajo para los proyectos en los que se habían comprometido y las dinámicas del grupo de amigos. Descubrí tardíamente, en el proceso de relectura de los materiales, que la "especificidad" que a mí me preocupaba en tanto investigadora era la otra cara de una disputa que se jugaba entre los distintos participantes del sello, en tanto tenían distintas ideas sobre lo que el sello era o debía ser. Estos sentidos me resultaron paradójicamente más claros una vez que el grupo de amigos comenzó a configurarse de otra manera: como se verá más adelante en este mismo capítulo, para algunos de ellos la gestión compartida del sello y "pasarla bien" era lo que hacía valiosa la experiencia en Concepto Cero y discontinuaron su participación una vez que el sello se embarcó en un proceso de profesionalización que comprometía el lazo de amistad y el imperativo del placer.

La literatura reciente que se ocupa de las escenas estéticas protagonizadas por jóvenes en Argentina y otros países de Latinoamérica coincide con mis avances de investigación en el hecho de que la amistad asume un papel central en estos emprendimientos, tanto en la música como en las artes visuales y otras apuestas vinculadas. Esta bibliografía enfatiza el carácter amical de las redes de producción, entendido a la manera del predominio de un lazo íntimo y/o familiar en sellos discográficos independientes y emprendimientos musicales de la CABA (Vecino 2011, Quiña 2012), en espacios de exhibición de nuevos artistas visuales en La Plata (López 2013), en editoriales independientes en la CABA (Vanoli 2009, Spilszbarg 2010), en redes de músicos de distintas ciudades españolas (Fouce 2012) y redes de artistas visuales en México (Gerber Bicecci y Pinochet Cobos 2012), entre otros. Pinochet Cobos (2015:75) indica que los procesos colaborativos que constituyen los jóvenes artistas visuales contemporáneos limitan con las fronteras de la fiesta, de la comensalidad y de la convivencia, tal como mostramos en este capítulo para el caso de los músicos del sello. ¿Qué papel tiene y qué sentido adquiere la amistad en Concepto Cero y otros sellos emergentes con los que me vinculé en la etnografía? 
En este contexto etnográfico, el amigo es el "socio" de un proyecto como el sello, es el que pone plata para un disco, es el co-equiper, el co-compositor, el compañero de banda, etc. En este sentido, los amigos no lo son porque se encomienden mutuamente sus penas y alegrías -si bien esto también sucede $\mathrm{y}$, como vimos, muchos se conocen desde la adolescencia-, sino que los amigos son amigos porque comparten de alguna manera unas reglas específicas para el trabajo artístico. La categoría de la amistad tiene una significación especial en este campo: no responde necesariamente a una amistad emocional e íntima -si bien esta puede manifestarse- sino a un lazo personal basado en la proximidad estética y ética. La amistad resulta más una forma de capitalización social para los músicos y productores estéticos a la vez que una forma de articular moralmente su mundo musical. En el primer sentido, la amistad refiere a las redes, conexiones y contactos, como parte de la organización y del sostén en la práctica de hacer música. Es lo que Gallo y Semán (en prensa) conceptualizan como una "cooperación interesada" en la complicidad, en un proyecto difícil: “vivir del arte". En el segundo sentido, generalmente el más resaltado por los músicos, la amistad debe entenderse a la manera de un compartir las propias reglas del trabajo artístico: en este sentido, los amigos son amigos porque se saben afines en una manera específica de ser músicos, de ser artistas.

Especialmente la primera dimensión aquí construida puede encontrarse en el trabajo pionero de Becker (2009) sobre los músicos de baile en los Estados Unidos, cuya investigación fue iniciada a fines de la década de 1940. Allí es posible leer a sus entrevistados afirmando que "otro modo de tener éxito es tener muchos amigos" (Becker 2009: 127) para connotar las conexiones que son necesarias para conseguir trabajo como músico. Más recientemente, en su trabajo sobre música emergente en España, Fouce (2012) sostiene que en este campo es necesaria una red real de amigos y favores para que los proyectos funcionen. En La Plata, López (2013) entiende que los espacios culturales de exhibición son sostenidos por colaboraciones enmarcadas en redes de afinidades y apoyos de amigos y conocidos. En un sentido más cercano a la segunda dimensión que planteé, Gallo (2011) apunta que las personas que trabajan en un boliche electrónico de la CABA lo hacen desde lazos de amistad trazados por la noche que les permiten compartir valores y modos de comportamiento que construyen desde su perspectiva un "verdadero" club de baile. 
En los estudios sociales de la música, este énfasis en los lazos de amistad se suele corresponder con una valoración de estas prácticas musicales como amateurs y poco profesionales (Palmeiro 2005, Corti 2007, Quiña, 2012) e incapaces de constituir una carrera (García Canclini 2012), criterios de evaluación que discutiremos en el capítulo IV. Justamente, Quiña (2012), asumiendo la centralidad de este lazo, afirma para la escena independiente porteña que la amistad, entendida como un vínculo personal directo basado en la afinidad y la camaradería, oblitera en estos contextos la problemática de las condiciones de trabajo y de la formación profesional. Por mi parte, sin dejar de reconocer el lazo característico de esta producción musical y analizándolo en su singularidad, pretendo indagar sobre la posibilidad de la coexistencia de relaciones de amistad con regímenes de profesionalización. Sin desconocer la existencia de condiciones inestables y frágiles en la producción musical - producto de una relación de fuerzas específica al interior de la sociedad capitalista contemporánea-, considero que la centralidad de la amistad permite a estos músicos manejar la precariedad en una práctica, inscribiéndola en una narrativa específica. En este sentido, la narrativa de la amistad no es falsa ni "esconde", al estilo de una falsa conciencia, una situación precaria. Más bien, todo lo contrario: opera en contextos signados por la fragilidad y la incertidumbre, permitiendo en parte el despliegue y el sostén de los proyectos musicales.

Como vimos, este tipo de complicidades y lazos de amistad se multiplican en mundos del arte distintos al que acá presentamos: galerías de arte, clubes de baile, proyectos de artistas visuales, editoriales artesanales. ¿Cómo los amigos conforman un sello musical tal como el que proponemos estudiar? Para comprender cómo los amigos producían música juntos bajo el rótulo de Concepto Cero relataré en lo que sigue el proceso de planificación, fabricación y presentación en sociedad del disco "Los Ellos" lanzado a fines del año 2011. Este caso también permitirá apreciar en qué sentido incluso un producto como un disco se producía más allá de lo discográfico y de lo sonoro, a partir de darle valor a otras producciones estéticas, que no meramente acompañaban los sonidos, pero también desde la forma en que la producción de un disco producía vínculos, alianzas y reputación. A partir de este caso, también podremos descubrir y analizar el tipo de compromiso que se instala a lo largo de este proceso en el grupo de amigos. 


\section{"Ahí aprendimos casi todo"}

"Los Ellos" es un álbum compilado de canciones e ilustraciones inéditas y originales en homenaje a la historieta El Eternauta ${ }^{48}$ de Hector G. Oesterheld y Francisco Solano López que Concepto Cero lanza en octubre del año 2011. El trabajo para llegar a este disco inauguró mi trabajo etnográfico y mantiene un papel estructurador de la mayoría de las actividades del sello durante mi primer año de acompañamiento. "Los Ellos" es el tema principal de conversación en las reuniones a las que asisto, es de lo que tratará en gran medida el trabajo de los amigos durante todo el año -trabajo en el que me veré implicaday es el centro de la celebración que, choripanes de por medio, haremos a fin de noviembre, luego de las presentaciones del disco en Mar del Plata -en el marco del festival Trimarchi DG- y en La Plata. Pero entre los festejos de aquel entonces, "Los Ellos" también marca una serie de tensiones y desplazamientos en el "grupo de amigos" de Concepto Cero, a razón de la colisión de diferentes maneras de entender y practicar la gestión entre amigos.

Cuando comencé a seguir las actividades de Concepto Cero, la división del trabajo estaba menos desarrollada que en años siguientes. Los amigos ocupaban posiciones caracterizadas por cierta fluidez y dinamismo. Si bien cada uno ponía en juego una orientación específica -la gestión, la comunicación, la producción, el diseño, la fotografía-, "todos estamos aprendiendo", como se enfatizaba en ocasiones durante las reuniones, además de que todos hacían un poco de todo. La actividad de gestión necesaria para llevar adelante sus proyectos era compartida hacia el interior del grupo, si bien los socios ponían más "compromiso" en ello. Las decisiones de catálogo eran tomadas por Matías y Nicolás con consideraciones de todos los demás, especialmente de los más cercanos, Tadeo y Cristóbal. Las inversiones financieras eran asumidas sobre todo también por estos cuatro últimos amigos, especialmente a partir de préstamos que pedían a sus padres. Por su parte, las características de los eventos se discutían en las reuniones de los miércoles. En ellos, podía encontrarse a los miembros de la "crew" rotando para encargarse de "la puerta" o "la taquilla", ya que no había personas específicas para esa tarea.

\footnotetext{
${ }^{48}$ Sobre la historieta, en el proyecto del disco que habían armado para pedir financiamiento, podía leerse lo siguiente: "El Eternauta es una historieta de ciencia ficción creada por el guionista Hector Germán Oesterheld y el dibujante Francisco Solano Lopez. Comienza a publicarse el 4 de septiembre de 1957 en la revista Hora Cero Semanal, de Editorial Frontera". Y también una valoración: "Entendemos a El Eternauta como un obra que nos representa como país dado que forma parte de nuestra historia e Identidad. Manteniéndose vigente 50 años después de su primera edición". (Concepto Cero, 2011)
} 
La división del trabajo en Concepto Cero se presentaba bastante débil en comparación a los sellos "independientes" que en algunos trabajos se dimensionan como pequeñas empresas (Palmeiro 2005). De acuerdo a las observaciones que fui recabando hasta fin del año 2011, Matías y Nicolás eran las dos personas que más cantidad de trabajo dedicaban al sello. Las reuniones - con otros sellos, bandas, funcionarios estatales-, los arreglos con los dueños de bares, la coordinación de los eventos, la responsabilidad de dar entrevistas a radios y publicaciones impresas, los criterios en la gestión de las redes sociales y especialmente el manejo del "dinero del sello", dependían en buena medida de ambos.

Sin embargo, esta división de tareas no resultaba del todo satisfactoria para los socios. A mediados de 2011, cuando ya el disco había entrado en su etapa final de producción, con Nicolás esperábamos en un café que llegaran los demás para comenzar la reunión. Entonces él me dijo que en el último ciclo del hostel habían tenido "problemas de comunicación con los artistas", además de que habían faltado cortos para proyectar. Nicolás atribuía estas dificultades al hecho de que había sido Cristo el encargado de esa edición del ciclo. Cuando empezó la reunión, Nicolás propuso junto a Matías que el Ciclo en el hostel esté organizado a partir de "roles fijos". Contemplaba que se puedan rotar pero que estén establecidos porque de otra manera, afirmaba, "queda todo en Mati y yo". A tono con estas expectativas, en la presentación del disco y las actividades que siguieron, se orientaron a dividir más el trabajo. Bajo la coordinación general de Nicolás y Matías todos los integrantes del grupo realizaron un sinfín de trabajos, si bien existieron algunas orientaciones específicas.

La importancia estratégica de "Los Ellos" era permanentemente señalada por los músicos de Concepto Cero: visibilizaba el sello al interior del mundo musical independiente a partir de una propuesta ambiciosa y original, además de congregar bandas relativamente más conocidas que las que en ese momento formaban parte del catálogo. Para el 2010 -año en el que están fechados los primeros documentos sobre "Los Ellos" en el Google Drive que me compartieron- pude observar que ya estaban trabajando en las colaboraciones de Mostruo y Norma, bandas con una trayectoria reconocida en la ciudad de La Plata, a la vez que con La Patrulla Espacial y Shaman y los Hombres en Llamas, bandas con cierto renombre entre las propuestas más nuevas. Además, el proyecto había realizado invitaciones a Los Natas y Él mató a un policía motorizado, grupos que finalmente no 
fueron de la partida. Incluso años después de la salida del álbum, mis interlocutores presentaban "Los Ellos" como una "obra emblemática" de la propuesta del sello. En esta tónica, a mediados del año 2012, en una reunión de sellos y colectivos emergentes, Ángel presentaba a Concepto Cero a la luz de la noción de colaboración y a "Los Ellos" como la obra que representaba cabalmente su espíritu. En una confirmación de esta mirada propia, un agente de prensa les decía, en una reunión unos años después: "Los Ellos los posicionó”, y Cristóbal le respondía: "Ahí aprendimos casi todo".

En efecto, el grupo se había encargado de realizar un disco compilado con 17 bandas participantes, desde su planeamiento en las conversaciones y las pantallas de la computadora hasta la venta y presentación: escribir el proyecto de subsidio para la Secretaría de Cultura de la Nación; conversar y negociar con ciertos privados; contactar y convencer del proyecto a las bandas y los artistas visuales; gestionar los derechos de las canciones; diseñar el packaging del álbum; llevar el disco a fabricar y luego ir a buscarlo; buscar y conseguir lugares para la presentación fueron tareas que se dividieron entre todos pero que llevaron a cabo sobre todo Nicolás, Matías y Cristóbal.

Mis interlocutores querían que el disco excediera la escena local, por lo que convocaron no sólo a artistas platenses sino a otros procedentes de distintas ciudades de la provincia de Buenos Aires, del conurbano bonaerense y barrios de la Capital Federal además de Bradien, una banda de Barcelona conectada por el grupo español que financió parte del disco. En las gestiones con las diferentes bandas, realizadas principalmente por Cristóbal, Nicolás y Matías, las redes sociales virtuales fueron determinantes, si bien procuraron también tener reuniones en directo y en un mismo lugar físico. Todos los proyectos participantes eran posibles de clasificarse bajo una noción de lo independiente: o son gestionados por sus propios músicos -Mostruo, La perla irregular, Bradien, Los dientes, Cinemática, Supersivo, Cristian Aldana y Diego Boris- o bien trabajan con sellos musicales pequeños y generalmente de gestión colectiva -al momento de la edición del disco: Dietrich, La Patrulla Espacial y Pommez Internacional con Sadness Discos ${ }^{49}$, normA

\footnotetext{
${ }^{49}$ Sadness Discos es un sello que proclama la "independencia" y la "autogestión", que inició sus actividades en el año 1996 en la CABA. Además de editar discos, organiza festivales a nombre del sello, entre otras actividades.
} 
con Scatter Records ${ }^{50}$, Fútbol con Oui Oui Records ${ }^{51}$, Shaman con Laptra ${ }^{52}$. Todas las bandas en ese momento catalogadas en Concepto Cero son de la partida: Brahmán Cero, Casimiro Roble, Excursiones Polares, Tata Laxague.

Entre estas bandas y solistas participantes del álbum se observa una marcada heterogeneidad con respecto al estilo musical: el rock sucio y potente de El Perrodiablo, los pasajes punk de Fútbol y el blues de inspiración psicodélica de La Patrulla Espacial conviven con el pop de cuidados arreglos de voces de Excursiones Polares, las mezclas electroacústicas de Tata Laxague y el folk de Shaman y los hombres en llamas. El eclecticismo era una marca del catálogo en ese momento, y dicha elección estética se repitió en el compilado. Lo que realmente se esperaba no era la adhesión a alguna clase de estilo o género musical específico, sino la calidad de la composición, la ejecución y la grabación de la canción, evidencia del compromiso con el que se devolvía la invitación a participar del proyecto. Esto resultó claro cuando una banda envió un tema que para todos resultó “malísimo" y un "desastre”. Matías consideró que no sólo era malo sino que parecía que lo habían hecho "a las apuradas", Nicolás coincidió en que "no se lo tomaron seriamente" y Tadeo agregó "es como si nosotros hiciéramos un trabajo así nomás, de raje”.

Quizás previendo la posibilidad de una situación de esta clase -aunque las otras canciones, más allá de las preferencias particulares, no trajeron inconvenientes- Nicolás, Cristóbal y Matías habían realizado un acuerdo con Estudio Tolosa, considerado uno de los mejores de la ciudad, en el cual la mayoría de las bandas aprovechó para grabar su canción, lo mismo que con Astor Mastering, un emprendimiento de un conocido productor de la ciudad orientado a la masterización, Juan "el Cana" San Martín. De este modo, se aseguraban un sonido prolijo de acuerdo a sus criterios y un buen audio, a cambio de publicidad en los eventos y en el disco para estos dos actores de la música local. Además de

\footnotetext{
${ }^{50}$ Scatter Records es un sello con sede en la CABA que opera desde el año 2003. Además de editar discos tiene una productora que ofrece venta de shows a nivel nacional e internacional para bandas, eventos y festivales; producción de eventos; asesoría contable y jurídica para eventos, contratos artísticos y derechos autorales, entre otros servicios.

${ }^{51}$ Oui Oui Records es un sello de la CABA fundado en el año 2002. Se dedica a varios géneros y estilos musicales: del rock stoner al reggae, el pop electrónico y el tango. Entre sus artistas figuran bandas de mayor convocatoria que las de Concepto Cero y sus sellos amigos, entre ellas Mimi Maura, Pequeña Orquesta Reincidentes y Los Natas.

${ }^{52}$ Laptra es un sello de la ciudad de La Plata que inició sus actividades en el año 2004. En La Plata, decir Laptra equivalía en algunos circuitos a decir indie. Entre sus artistas se encuentran: Él Mató A Un Policía Motorizado, 107 Faunos, Antolín, Go Neko, Las Ligas Menores, entre otros.
} 
este tipo de intercambios de servicios, y del "subsidio de Nación” sobre el que hablaré más adelante, el disco se financió con aportes de Trànsit Projectes, una organización radicada en las ciudades de Barcelona y Madrid (España) orientada a la consultoría y gestión cultural. De esa manera, una parte de las copias realizadas se enviaron a España y, a lo largo de los años siguientes, continuaron las colaboraciones con este equipo.

Por otra parte, el álbum incluía doce postales ilustradas que podían intercambiarse para hacer las veces de 12 tapas. Estas piezas gráficas sumaban a los diseñadores de la "crew" -Tadeo, el Pampa, Mariano y Corina- otros artistas amigos: Acampante y Pacheco, los creadores de la convención de diseño Trimarchi DG en la que Concepto Cero participaba en la producción, y las Tormenta, con quienes el sello hacía fiestas en colaboración, las cuales continuarán en el resto del período estudiado. Completaban el grupo Dr. Alderete, Marina Fages, Freshcore, Antonio Gagliano y Los amigos de la imagen. A partir de la observación de la división de tareas en las reuniones, pude comprobar que Tadeo era a todas luces el encargado de vincular a los distintos ilustradores y artistas plásticos con el proyecto. Había sido el responsable de conversar con los artistas sobre las imágenes y ahora se encargaba de recibirlas, de estandarizar sus formatos, de comandar su impresión en postales y banners, averiguando precios de papeles y de trabajos de imprenta. Junto al grupo más amplio de diseñadores habían proyectado el packaging del disco, con intervenciones de todo el grupo.

El armado del packaging del disco físico contempló dos solapas internas para imprimir fotografías, de modo que los dos fotógrafos del sello pudieran participar de esta instancia. Asimismo, en el proyecto original -extraído del Google Drive del sello- se estipulaba que "el proceso creativo de cada uno de los artistas y productores será documentado y presentado al público en tiempo real, con una cobertura audiovisual y fotográfica. Este material se publicará como contenido en la web específica de "Los Ellos". Al finalizar el proyecto, se compilará lo más relevante en un documental”. Efectivamente, en la presentación del disco en La Plata -noviembre de 2011, Centro Cultural Islas Malvinas- y en CABA - marzo de 2012, Niceto Club- antes de la actuación de cada banda se proyectó un adelanto de unos cinco minutos del documental de producción de la canción con la que ese grupo había participado en el compilado. La realización del documental completo, a cargo de Pi producciones, la productora del hermano de Matías, se demoró y 
fue estrenado recién en septiembre de 2012 en el FESAALP, luego de todas las presentaciones del disco.

Los integrantes del sello entendían que "Los Ellos" era una obra conceptual e interdisciplinar. Para este disco se observa una interesante instrumentalización de este carácter interdisciplinar, logrado en parte por el tránsito en las redes estudiantiles de La Plata y por la confluencia en un mismo producto de los saberes de los distintos amigos pero presentado como una búsqueda consciente en la que además radicaría su atractivo. El carácter interdisciplinar del proyecto se presentaba en un lenguaje profesional: se trataba de una opción atenta a las tendencias contemporáneas de mixtura entre las artes. A su vez, se presentaba como una propuesta conceptual, ya que todas las obras sonoras y visuales giraban alrededor de una temática impuesta por la obra literaria.

Tanto en el caso de los músicos como de los artistas visuales, fotógrafos y documentalistas, "Los Ellos" evidenciaba una motivación en Concepto Cero por promover los artistas propios, a la vez que tender vínculos con otros externos, con quienes se consideraba la posibilidad de trabajo conjunto en otras instancias - desde la organización de una fecha en común y alianzas futuras al interior de la escena, hasta cuestiones más comprometidas como el booking ${ }^{53}$, la producción de eventos y, finalmente, la inclusión en el catálogo. Varios grupos que participan del compilado serían sumados al catálogo del sello años después -El Perro Diablo y Shaman, con la formación Shaman y los Pilares de la Creación-, a la vez que Mostruo pasará en el año 2012 a ser "bookeado" por el sello por un breve período de tiempo. De la misma manera, una relación que había comenzado a partir de la ilustración y el diseño se desplazaba hacia la música: en el año 2013, el dueto musical de Marina Fages con Lucy Patané fue trabajado y lanzado por Concepto Cero. Retrospectivamente, "Los Ellos" se podía ver como una apuesta por desarrollar proyectos más allá del grupo de amigos que gestionaba el sello. Este tipo de apuestas ampliaría en el largo plazo los amigos y los aliados del sello.

Al término de las presentaciones del disco en La Plata, el malestar entre los miembros del grupo era notorio. Ya en el mes de diciembre, en la última reunión de ese año -en la que sólo estábamos Nicolás, el Pampa y Tadeo-, Nicolás decía: "Este año no la pasamos muy bien y es algo que no nos gusta cómo fue", mientras Tadeo insistía en el

\footnotetext{
${ }^{53}$ Con esta palabra se refiere la venta y comercialización de presentaciones y shows.
} 
componente del "aprendizaje" y la "amistad" por sobre todas las cosas. Unos años después, en una entrevista brindada a Los Inrocks, la edición web de la revista Los Inrockuptibles, Nicolás refería al momento posterior a "Los Ellos" como "un quiebre de profesionalización" ${ }^{54}$ luego del cual la organización y los roles en el sello habían comenzado a cambiar.

\section{Comprometidos y colgados}

Como vimos, las tareas para la producción del disco "Los Ellos" habían sido de lo más variadas. El proceso fue realmente exigente y la forma en que las miradas desencontradas de los distintos amigos intervenían en el proceso de producción difícilmente pueda ser exagerada: discusiones, críticas recíprocas, y finalmente un caso de cese de la participación en el grupo estable del sello. Es luego de la presentación en La Plata que Matías comunica en privado a los más allegados su decisión de abandonar el sello para dedicarse a terminar la carrera universitaria que seguía en la UNQUI y a su estudio de grabación, hastiado de las tareas de gestión que le imponía Concepto Cero ${ }^{55}$; mientras otros hablaban de "desgaste", a la vez que en las reuniones de diciembre Nicolás les proponía al Pampa y a Tadeo nuevas formas de relacionarse con el sello, a la vista de lo difícil que había resultado la experiencia recientemente pasada.

La presentación del disco tuvo lugar en el Centro Cultural Islas Malvinas entre el viernes 28 y el domingo 30 de octubre de 2011. El día viernes tocaron Tata Laxague, Excursiones Polares y Shaman y los Hombres en Llamas; el sábado Supersivo, Casimiro Roble, La Perla Irregular y El Perrodiablo; mientras que el domingo Cinemática, Mostruo! y La Patrulla Espacial. La propuesta se completaba con la exposición de los artistas que habían realizado tapas para el compilado y de otras instalaciones visuales e interactivas,

\footnotetext{
${ }^{54}$ En: "Concepto Cero, un punto de partida". Entrevista a Concepto Cero por Romina Zanellato, 21 de julio de 2015. Recuperado de: http://www.losinrocks.com/musica/concepto-cero-un-punto-departida\#.VrQKJdLhArg

${ }_{55}$ Matías abandonó el sello pero no su banda, que siguió formando parte del catálogo, ni mucho menos su estudio, en el cual muchas bandas del sello grababan, mezclaban y masterizaban. Además, siguió comprometido con el proyecto "Los Ellos" y trabajó en la última presentación del álbum el 24 de marzo de 2012 en Niceto. También tocó con Casimiro Roble en el aniversario de Concepto Cero de abril del 2012, en una presentación conjunta preparada para la ocasión con la banda de Nicolás. Ambos continuaron su amistad: Nicolás decía "yo a Mati le soy incondicional". En el capítulo IV, presento y analizo la práctica profesional de Matías en el estudio, en relación con las diversas posibilidades profesionalizantes que se abren en estos mundos musicales.
} 
montaje realizado por el grupo de diseñadores del sello. La muestra se había montado en el microcine del centro cultural y tras una mesa de madera bastante grande se exponían los discos y unas tarjetas referidas a él. En la inauguración de la muestra no faltaron los vinos y un discurso sensiblemente poético preparado por Julia, una amiga del secundario de los chicos.

Si bien este no fue el primer caso en el que ayudé con alguna de las actividades de la presentación en vivo ${ }^{56}$, fue el primer evento del sello en el que me compartieron por mail una grilla de trabajo, dividida en dos tareas -"stand y taquilla" y "entrada del auditorio"repetidas en tres bloques horarios $-17: 30$ hs a 19:30 hs., 19:30 hs. a 21:30 hs. y 21:30 hs. hasta el final- durante los tres días sucesivos que tenía lugar el evento: viernes, sábado y domingo. La idea era que Melina, Cristo, Tadeo, Mariano cubrieran casi todos los horarios, sumados a las voluntades más puntuales de Matías; Julián, el hermano de Matías; Corina, que había participado con una postal; Amparo, una amiga fotógrafa de Cristo; Nicolás Reyes, el bajista de Brahmán Cero y la mía propia. Nicolás aparecía sólo en una tanda horaria y Matías en ninguna: la idea era que ambos estuvieran supervisando el total de las actividades y, de hecho, así aconteció esos días. De los fotógrafos se esperaba que cubrieran el evento, por lo que tampoco se los incluyó en la grilla.

No obstante la grilla no funcionó tal como estipulaba el papel: el sábado, Melina llegó recién a las siete, o sea media hora antes que terminara el horario que debería cumplir. Sobre esto uno de los chicos se quejó conmigo: “Che, qué copada Melina, tenía que venir a esta hora, era su turno". Por su parte, Mariano ni apareció. Otro de los "colgados" fue Pancho, quien protagonizó una serie de "faltazos" a eventos vinculados a "Los Ellos" que debía cubrir con su cámara y en los que el resto tuvo que recurrir de emergencia a Cata. Obtener el compromiso y "armar un equipo" siempre fue una de las tareas clave no escritas en ningún plan de proyectos del sello. Desde un comienzo, las pequeñas discusiones cotidianas en las reuniones revelaban los criterios de trabajo dispares que entraban en conflicto, marcando los límites de lo que cada uno estaba dispuesto a dar. Actitudes como

\footnotetext{
${ }^{56}$ Dado que yo no contaba con competencias ni artísticas ni técnicas suficientes a los fines de "operar las luces" o "pasar música", mis primeras actividades en el sello tuvieron que ver con "hacer la taquilla" o encargarme de la "mesita de discos" en los distintos eventos. Esta fue una manera de empezar a hacerme "amiga" en el sentido propio del grupo especificado. En el próximo capítulo desarrollo cómo desde la perspectiva de mis interlocutores mi perfil profesional se volvió un recurso para el proceso de profesionalización musical.
} 
no responder los mails, llegar tarde a las reuniones, no asistir a horario a cubrir puestos de trabajo en un evento, eran típicamente marcadas como faltas por los más comprometidos. La mayor implicación de los demás en las actividades del sello era requerida por los “socios", especialmente por Nicolás, que establecía mociones de orden en las reuniones cuando los demás se dispersaban y frecuentemente me contaba de sus intentos por delegar tareas en los demás.

En "stand y taquilla", tarea que cumplí en dos tandas horarias el sábado y en una el domingo, se trataba de vender los discos y de cobrar las entradas. Antes de empezar, Cristo me mostró unas planillas para el viernes, el sábado y el domingo con diferentes categorías de venta a completar: entrada, disco, entrada con disco, entrada para dos días y abono por tres días. Me mostró la planilla del día anterior como ejemplo y me indicó que usara otra planilla. También me mostró las entradas - de diferentes colores para cada día: rojo, amarillo y verde. En el reverso de la planilla del viernes también estaban las personas en "lista", es decir, los invitados que no abonan entrada. En la lista se encontraban personas muy allegadas como los padres y madres de los organizadores, algunos amigos de la escena, algunos periodistas. Era posible que las distintas bandas participantes sumaran invitados, incluso en el mismo momento, si bien con mucho menos poder de intervención que si fuera una fecha propia.

Las invitaciones de entradas y los regalos de discos, así como el precio de venta tanto de unas como otros, habían sido temas de negociación al interior del grupo organizador, por lo menos desde septiembre. Para Nicolás era importante intentar que en las primeras semanas en las que el disco estuviera a la venta -desde fines de septiembre de 2011, con la presentación en Mar del Plata del álbum- se vendiera la mayor cantidad, incluso a los amigos. Por el contrario, según Tadeo, a los amigos había que regalarles el disco. En una reunión del sello Tadeo argumentó que tenía pocos amigos, "amigos, amigos para regalarle el disco" y que "con Mariano [el otro diseñador del sello] tenemos los mismos amigos". Mientras Tadeo activaba una noción de la amistad intima y emocional, Nicolás establecía en un Excel compartido en el Google Drive una lista de periodistas amigos, tanto de medios gráficos como de radios locales y de la CABA, a quienes había que hacerles llegar una copia física del disco. 
En aquel período, en las redes estéticas de La Plata que Concepto Cero frecuentaba una vía importante de acceso al disco físico era de mano en mano, a través de relaciones personales con los músicos, los managers, los periodistas, las novias, los hermanos, en fin, los amigos. Por más de que en la escena los discos no fueran ajenos a una operación de ventas, un porcentaje considerable de la producción se intercambiaba -por discos de bandas amigas, por prensa en las radios, por reseñas en los medios escritos, por favores- o se regalaba por mediación de diversos tipos de amistad. Aunque ya en el año 2009 un músico del circuito indie "relajado" me había confesado en una entrevista que había que “demostrar que en cierta medida estaría bueno que lo compren” y otro me había retado porque había bajado de una página web su disco con un "No seas rata, los discos [de las bandas independientes] hay que comprarlos", era muy difícil para los músicos fomentar entre los amigos y conocidos la compra de los álbumes, más si eran periodistas. Aunque en la práctica luego los discos se hayan efectivamente regalado a muchos amigos, podría decirse que el afán de Nicolás en intentar en un principio cobrarlos cuestionaba la moral económica de algunos de sus colegas del sello.

Pocos días antes de la presentación en La Plata se desató otro conflicto acerca del destino de los discos en la reunión de los miércoles, con motivo del precio al que estos debían venderse en el evento. Se trataba de una discusión sobre el precio del disco "sin intermediarios", tal como lo definió Matías. Así lo registré en mi diario etnográfico:

Matías sostuvo que el disco debía venderse a menor valor que en las disquerías, donde iba a estar 50 pesos, por lo que proponía dejarlo a 40 pesos para el evento. Nicolás, por su parte, argumentó que el precio del disco "mano en mano" debía ser el mismo que en disquerías, poniendo el énfasis de su argumento en "el valor del producto". Frente a esta postura, el argumento de Matías estaba basado en los "intermediarios” que encarecían el valor. Nicolás insistía en el "valor del producto” y le decía a Matías: “¿Sabés cuánto está un disco en Musimundo? El de Babasónicos nuevo está ochenta pesos”. Melina respondió: "Bueno, pero es Babasónicos", riendo y dando a entender que no se podía comparar con "Los Ellos" y Tadeo acordó con ella a partir de un gesto facial. Nicolás seguía con el argumento del "valor del producto" y arriesgó: "Setenta es lo que habría que venderlo, es lo que vale", a lo que los gestos de "no, para nada" del resto fueron notorios. La discusión seguía y entonces 
Matías pidió mi opinión al respecto. Dije con voz baja y una evidente falta de autoridad: "Y... creo que tiene que valer menos".

En general, entre los músicos independientes, no estaba muy bien visto cobrar entradas ni discos excesivamente "caros", es decir, era esperable que estos productos se marcaran a un "precio amigo". Esto no significa que no existieran las preocupaciones monetarias pero la pretensión de Nicolás de cobrar el disco de "Los Ellos" como si se tratara del de Babasónicos resultaba desmedida para los criterios que estructuraban la moral económica de sus compañeros de sello. Por otra parte, para la mayoría de los músicos del período la obtención de réditos económicos se pensaba más que nada en relación con las presentaciones en vivo. No es que las ganancias por la venta de discos fueran insignificantes: como ellos decían "se gana algo de plata", pero principalmente se difunde la obra.

No obstante, la inversión relativamente alta que había implicado "Los Ellos” en comparación con el resto de proyectos de la escena cuestionaba estas ideas económicas de amplia circulación. Nicolás y Matías habían invertido considerables sumas de dinero propio en la financiación del álbum, además de que se "había caído un subsidio de Nación a último momento" con el que se contaba para financiar un disco, el cual ya estaba en fábrica y cuyos gastos, ascendientes a 15 mil pesos, había que cancelar pronto. Nicolás y Matías nos comunicaron este problema en una reunión invitándonos a hacernos cargo de los costos junto a ellos. La propuesta consistió en que cada uno de los presentes consiguiera dinero para la edición, asegurándose que esta iba a volver en un período de a lo sumo seis meses. Matías fue enfático en asegurar este retorno: nos contó que nuevamente él le iba a pedir $\$ 5000$ a los padres y luego aseguró "soy el que más se juega con esto". Ni él ni Nicolás estipularon un monto mínimo de participación pero nunca ejemplificaron con una cifra menor a 1000 pesos. Finalmente, Tadeo y Cristóbal pusieron dinero, a partir de préstamos que pidieron a sus padres. Yo misma fui interpelada por esta necesidad, y mi propio compromiso con el grupo, que hasta ese momento creía exclusivo con la investigación, se tradujo en un préstamo monetario.

El compromiso de los socios se actuaba no sólo a partir del trabajo dedicado al sello sino cada vez que invertían económicamente en él, y lo hacían como ninguno de los demás 
participantes. A la vez lo requerían de ellos, especialmente en los primeros años, cuando la inversión de los amigos era vital para seguir produciendo, en un contexto de autosustentabilidad donde "todo lo que entra sale". Pero "Los Ellos" había implicado inversiones importantes si se las comparaba con las apuestas acostumbradas por sus colegas y amigos de la escena: escasas sumas de dinero invertidas y poco riesgo, lo que permitía el funcionamiento sustentable con rendimientos económicos bastante precarios. Mientras se limitaran a la producción estética en el grupo de amigos se podía producir a relativo bajo costo. Por el contrario, "Los Ellos" fue absolutamente a pérdida y ese dinero lo perdieron Nicolás y Matías: en el año 2013 todavía no se había vendido la totalidad de copias realizadas del álbum, al punto de que una cantidad fue afectada por las inundaciones platenses de ese año. Por lo demás, las presentaciones, repletas de familia ${ }^{57}$ y amigos, convocaron menos personas que pagaran entrada. En la última de ellas -abril de 2012 en Niceto Club- Nicolás me dijo que habían entrado 280 personas en total entre prensa, invitados y entradas pagas, siendo esta última categoría la de menor convocatoria.

Luego de la partida de Matías a fin de ese año, Tadeo, Mariano y Melina también discontinuaron su participación en el proyecto. Si bien ninguno dejó de orbitar en estas redes - desde la asistencia a los eventos, la realización de algunos flyers, la promoción de las bandas en las redes sociales digitales, etc.-, abandonaron el espacio de trabajo regular y coordinado o el llamado "staff fijo". Matías continuó su relación con los chicos del sello a partir de su estudio, mientras Tadeo prolongó sus participaciones hasta bien entrado el año 2013. Mientras Mariano, de acuerdo al relato de Nicolás le había dicho que "estaba todo bien" pero que estaba "en otra onda" y que no quería trabajar más, Tadeo introducía la pista más interesante para comprender esta ruptura. De acuerdo a la versión de Nicolás, el diseñador argumentaba que "si [Concepto Cero] no era un grupo de amigos que hacían cosas a él no le interesaba". Nicolás acordaba con él en que el último año "el sello se había abierto a otras cosas", más allá del grupo de amigos. En un primer momento Nicolás se cuestionaba este desenlace: "Hay algo que está mal para que después de un proyecto tan grande mucha gente implicada en ese proyecto se baje", me decía. Tiempo después ya

\footnotetext{
${ }^{57}$ Era usual que los padres y madres de los miembros más activos de la "crew" asistieran a los eventos más importantes organizados por Concepto Cero, como fue el caso de "Los Ellos".
} 
habría resignificado estos alejamientos en los términos de un proceso de profesionalización con el que no todos estaban igualmente comprometidos.

Así, el grupo de músicos y artistas que durante la totalidad del período etnográfico efectivamente continuó en el núcleo activo del sello no sólo se consideraban "amigos" entre sí sino que daban por sentado estar comprometidos en una búsqueda específica de trabajo en la música, desmarcados de actitudes "relajadas" y "colgadas" -características que estos que se quedan asocian generalmente al cese de la participación plena de los otros. Esta es una nota que se sostendría en todo el trabajo de campo y que muchas veces se vinculaba a la acusación de jipis ${ }^{58}$, término con el que se procuraba señalar lo carente de carácter profesional. En la escena de La Plata que investigamos, el elogio del amateurismo iba de la mano con el de la amistad. En una reunión de Concepto Cero, mientras discutíamos las relaciones con otros sellos de La Plata uno de los chicos expresó categóricamente: “amistad no es jipeada". De esta manera, justificaban la combinación de lazos de amistad con la búsqueda de profesionalismo.

Luego de las rupturas que siguieron a la presentación de "Los Ellos", Nicolás se convirtió en el "coordinador" de Concepto Cero y conservó parte de las responsabilidades presentadas anteriormente, mientras otras fueron derivando y compartiéndose con Cristóbal, Anache, Ángel y otros músicos con proyectos catalogados en el sello que comenzaron a partir del año 2012 a participar con más fuerza que otros miembros en la toma de decisiones. Entre 2012 y 2015 pude participar de un proceso de profesionalización de la estructura de la organización y de las posiciones de sus integrantes que será descrita y analizada en el capítulo IV.

\section{"Un comodín para decir un montón de cosas"}

Del estudio del material empírico producido del primer año de trabajo con Concepto Cero (2011) y en las interacciones, especialmente durante el año 2012, con algunos otros sellos emergentes de la ciudad de La Plata como Dice Discos, Uf Caruf y Tomas del Mar

\footnotetext{
${ }^{58}$ Gallo y Semán (en prensa) documentan el uso de este término acusatorio en otras escenas musicales juveniles contemporáneas al caso que aquí estudiamos. Ellos señalan: "es necesario entender hasta donde, en estos contextos, "jipi” puede llegar a ser utilizado como categoría crítica en un ámbito que visto desde las pautas de las generaciones precedentes resulta "hippie"."
} 
Muerto, además de los desarrollos de la investigación anterior entre músicos de un sello orientado a la música indie (2009-2011), fue posible establecer algunas características comunes entre los sellos que funcionan como un "grupo de amigos". Esta noción la retomo de las propias clasificaciones de mis interlocutores: como se señaló al inicio del capítulo, esta era la forma habitual en la que estos emprendimientos conjuntos se presentaban públicamente, además de hacer las veces de referencia para hablar de una configuración de la que uno podría querer acercarse o distanciarse. Más allá de las diferencias que pudiera haber entre los sellos musicales en cuanto al proceso que los había constituido como colectivos, la estructura de toma de decisiones y el catálogo, se percibía entre ellos un aire de familia en la manera en que sus participantes se reconocían en los mismos problemas y en parte, como veremos en el capítulo III, en las mismas soluciones.

Un sello de este tipo es una red de artistas, especialmente músicos, con quienes se comparten "fechas", salas de ensayo, estudios de grabación, equipos, como también contactos e información. Es decir, los participantes de los diferentes proyectos suelen trabajar en conjunto, produciendo unos para otros. Se trata de programar los eventos, contactar e invitar a otros a participar, tratar con los empresarios y/o encargados de los locales, difundir sus presentaciones, a la vez que grabar y mezclar discos, diseñar sus tapas, llevar la grabación a la fábrica, elaborar los afiches, etc. De esta manera, resultaba común ir a un recital y que un músico de otra banda, algún amigo o pareja, cobre las entradas, o bien haya prestado algún instrumento o se haya encargado de diseñar el flyer. Asimismo, en los créditos de los discos puede leerse que los músicos son los encargados de producir la gráfica de otro disco de otro grupo musical. O que las participaciones en calidad de "músicos invitados" en la mayoría de las veces no implican remuneraciones en moneda pero sí intercambios de publicidad, instrumentos y compartir "fechas" para tocar".

Estos sellos presentan una división de trabajo poco desarrollada y no tienen sedes físicas oficiales, si bien esto no implica su virtualidad. Se conforman a partir de convivencias dilatadas en distintos espacios en que se vuelve más fácil gestionar el

\footnotetext{
${ }^{59}$ Los sellos, desde ya, no son el único espacio en el que en el mismo período se desarrollan estrategias de cooperación entre artistas y colectivos de artistas. Lamacchia (2012), por ejemplo, documenta la creación en el seno de la Unión de Músicos Independientes (UMI) de la UMIRED en la que los músicos auto-gestionados de las distintas bandas asociadas se comprometen para ayudarse en los distintos shows, de modo que unos harán la asistencia técnica, otros la puerta, mientras unos terceros se encargarán de la venta de discos en el evento.
} 
proyecto musical. Suelen carecer de una estructura más o menos establecida de toma de decisiones: si bien la mayoría organiza reuniones específicas del sello, las medidas a tomar -por ejemplo, sumar nuevos proyectos musicales, realizar un festival del sello, cambiar la página web- se traman más bien en ámbitos cotidianos, entre las redes de un grupo donde existen núcleos y periferias móviles, y afinidades más fuertes con unos que con otros. Como me decía en una entrevista a comienzos del año 2013 Diego de Desde el Mar, un sello de Mar del Plata realizaba actividades en conjunto Concepto Cero: "Una de las primeras cosas que hablamos es que todos los que estábamos en el sello todos trabajábamos para el sello. Yo lo que puse en claro al principio, porque yo ya me la veía venir, era tipo "yo no voy a trabajar para todos, todos trabajemos para todos"”. Con sensibles diferencias en la manera en que se reclama compromiso y trabajo en el proyecto, estos sellos han institucionalizado la red de cooperación entre amigos en un rótulo bajo el cual editan discos, pero también asumen otras actividades, especialmente la organización de eventos.

Durante los dos primeros años de mi trabajo etnográfico, estos sellos se caracterizaban por no financiar los discos que se encuentran en su catálogo, lo que corre por cuenta de las bandas. No obstante, era común que artistas se acercaran a ellos generalmente mediante correos electrónicos o mensajes en las redes sociales- con la fantasía de poder obtener un trabajo de financiación y/o edición discográfica de su parte. Así, los músicos me confirmaban que la mayoría de las bandas que les mandaban mails para ingresar al catálogo no sabía exactamente cómo funcionaba su sello. La misma sensación experimentaban algunos músicos de Concepto Cero con respecto a la postura de la UMI, para quien el actor independiente por excelencia era el músico y no el sello, incluso cuando tenía las características descriptas aquí ${ }^{60}$. En una de las reuniones de músicos a las que asistí durante el año 2012, el representante del sello de Córdoba Ringo Discos daba cuenta de esta confusión: "Si viene alguien y nos dice 'yo quiero estar en Ringo Discos', la respuesta es 'pero vos sos Ringo Discos, vos te a vas a editar'”.

\footnotetext{
${ }^{60}$ Como portavoz de la postura de la UMI en este punto, Lamacchia (2012: 122) sostiene que es más adecuado hablar de sellos nacionales o locales, para diferenciarlos de las grandes compañías multinacionales, antes que de sellos independientes. Para la UMI el músico es el actor independiente, y el sello también lo será toda vez que el artista independiente sea su propietario (es decir, como planteaba Shaman al comienzo de esta tesis: que el músico sea su propio sello). Como se ve, además de responder a una disputa por la categoría independencia común en este mundo musical, estas afirmaciones no consideran la especificidad del sello musical emergente que tomo como objeto en esta tesis.
} 
Es cierto que el público "amigo" y "prosumidor" construyen estos sellos: músicos que son fans de otros músicos, bandas que son el público y el sostén de otras bandas de su propio sello o de sellos amigos, diseñadores, fotógrafos y demás productores estéticos que trabajan pero también consumen la música que les gusta, "públicos" que producen videos, fotos, textos y otros materiales a partir de sus canciones y bandas favoritas. No obstante, en los últimos años algunas bandas y eventos comienzan a cosechar simpatías y seguidores más allá de este núcleo de amigos: en el año 2014, Güacho del sello Tomas del Mar Muerto hizo un show en el Galpón de las Artes cuya asistencia se calculó mayor a 800 personas; en el 2015, Un Planeta de Dice Discos hizo lo propio con 600 personas. Asimismo, son visibilizados por iniciativas del gobierno local, provincial y nacional, como presentaré en el próximo capítulo.

Sin pretensión de exhaustividad, es productivo traer a colación ciertos antecedentes de instituciones que se pueden asociar a estos sellos. El caso pionero de MIA (Músicos Independientes Asociados) ${ }^{62}$, una cooperativa de músicos, o mejor "una especie de club de música progresiva" (Pujol 2005: 32) que se conforma hacia el año 1975 quizás sea el primer caso que conozca la tradición del rock local de músicos que se hicieron cargo de la gestión de la propia obra. Mientras en esa época la mayoría de los músicos se dedicaba sólo a las tareas de la composición y ejecución musical, los de MIA se involucraron también de calcular los costos, conseguir materia prima, cobrar las entradas, producir el arte de tapa de los discos, resolver el problema del transporte, el sonido y la iluminación en los espectáculos, así como la distribución y la venta de los discos. Los músicos de MIA también fueron los primeros en financiar sus propios discos, incluso antes de publicarlos, a partir de las contribuciones de sus seguidores a quien luego se les enviaba el disco por correo (Lamacchia 2012: 52) ${ }^{63}$. De acuerdo a Lamacchia (2012: 55) varios sellos posteriores fueron influenciados por MIA: Circe (fusión), Plot (rock) y Macondo (folklore), todos los cuales usaron la técnica del fichero en los shows con los datos de los seguidores

${ }^{61}$ Del inglés "prosumers", acrónimo formado por la fusión de las palabras producer -productor- y consumer -consumidor-, retomo este término de Weber y Mitchell (2008:27), quienes a partir del análisis de las nuevas tecnologías, quieren dar cuenta de cómo actualmente los procesos de producir y consumir están interrelacionados y a menudo son simultáneos.

${ }^{62}$ MIA fue conformada por muchísimos músicos que respondían a una estructura familiar comandada por Esther Soto y Donvi Vitale y sus hijos, los hermanos Liliana y Lito Vitale.

${ }^{63}$ Durante el período de investigación, Concepto Cero y Ciudad Alterna utilizaron el crowfounding, un sistema actual que reformula a través de las redes de Internet el financiamiento colectivo por parte de los seguidores y simpatizantes. 
para difundirse. MIA dejó una huella indeleble en una de las bandas "independientes" y "autogestivas" paradigmáticas de la historia del rock nacional, Los Redondos, quienes editaron su primer disco bajo UORMO, un subsello de la cooperativa pionera. En la década del 80 se documenta una escena $u n d e r^{64}$ donde encontramos, entre otras, las iniciativas de Radio Trípoli, un sello punk que editó el mítico disco "Invasión 88”, y Catálogo Incierto, un sello comandado por Daniel Melero que además de trabajos propios editó a Mimilocos, Los Corrosivos, Todos Tus Muertos y Don Cornelio (Fernández 2012: 138). Unos años después, en 1989 nacía Melopea Discos, un sello creado por el músico Litto Nebbia, uno de los precursores de la figura de los músicos gestores que analizaremos en el capítulo IV. Para la década de 1990, algunas bandas "alternativas" y especialmente las bandas "barriales" ${ }^{65}$ practicaron la autogestión. Sobre ellas, el periodista Pablo Schanton afirmaba: "Hoy, que la moda mundial es mostrar cínicamente cómo una banda es producto de la manipulación de la industria (...), los nuestros defienden sus sellitos discográficos (Patricio Rey Discos, El Farolito, Besótico, Ugly, Silly ${ }^{66}$ ) mientras trabajan rodeados de amigos y familiares..." (Schanton 200: s/n).

Es posible enumerar una serie de sellos independientes creados por músicos que guardan afinidades estéticas y organizativas con los que estudiamos actualmente en La

\footnotetext{
${ }^{64} \mathrm{El}$ under o el underground es un concepto que en nuestro país emerge en esa década, en contraposición a la masificación del rock luego de la guerra de Malvinas. Acerca del uso del término, López (2012) relata lo siguiente: "Consultado en una conferencia sobre el origen del término underground, Pipo Lernoud, uno de los creadores del Expreso Imaginario y protagonista de primera hora del rock en Argentina, respondía sin dudar que en los años 60 nadie utilizaba ese término. "En tal caso se hacían revistas subte y existían lugares de reunión como La Cueva y la Perla del barrio de Once, pero el término underground no estaba en el vocabulario de los 60 y 70". Sin embargo no dudó en marcar los 80 como un corte brutal cuándo, luego de Malvinas y el nacimiento del rock nacional, los músicos debieron convivir con los empresarios". En este contexto, el under se caracterizó por una la confluencia entre poesía, música, teatro y artes visuales. Es en esta década que surgen en la Ciudad de Buenos Aires salas prototípicas del under como el Parakultural y Cemento -los testimonios sobre Cemento recopilados por Igarzábal (2015) dan cuenta de dicha interdisciplinariedad. El concepto under tenía una historia un poco más larga en Estados Unidos e Inglaterra, sedes fundadoras de la cultura rock y pop internacional. Tal como recupera Reynolds (2009: 200) en sus inicios la noción under refería a llevar un estilo de vida inconformista y en oposición al establishment. Más adelante, el punk y el post-punk renovaron este significado y le otorgaron una infraestructura: los sellos independientes de ideales colectivistas y relaciones de no explotación con las bandas. En los años 90, los inicios de la rave revitalizaron el sentido del under y del do-it-yourself. Es necesario señalar que las reflexiones de Reynolds retoman los sentidos y usos de estas nociones desde una historia internacional del rock que en realidad es su historia en sus países de surgimiento.

${ }_{65}$ Lo que se denominó por entonces rock chabón fue sustentable a partir la estabilización de circuitos de shows en locales de mediano y pequeño porte, logrados gracias al "aguante" de los seguidores (Semán 2006).

${ }^{66}$ Refiere a los "sellitos" creados respectivamente por Los Redondos, Los Piojos, El Otro Yo, Nekro (ex Fun People) y Timmy McKern, editor del debut de Sumo y luego de Las Pelotas. La mayoría de estos sellos se limitaron a editar a sus creadores y alguna que otra banda "amiga".
} 
Plata. De la mano de una noción de lo "alternativo", durante la década del 90 comenzaron a editarse tanto a sí mismos como a otros artistas con los que compartían escenarios y amistad: en la CABA, Sonoridades Amapola, iniciado por el grupo electrónico Estupendo, que editó discos de Trineo, La Nueva Flor, Carola Bony, Carca y Dj Trincado; mientras F.A.N., iniciado por Suárez -el primer grupo de Rosario Bléfari, artista que es reconocida como pionera en la escena que estudiamos- editó a Paoletti, Victoria Abril y Fantasías Animadas. Por los mismos años, en La Plata, 1.2 Records se hacía responsable de la edición de materiales de figuras del llamado "rock platense" como Las Canoplas y Mister América. Más allá de referencias periodísticas contadas, la información sobre estos sellos es prácticamente inexistente. Es difícil, por lo tanto, establecer comparaciones con nuestro caso en lo que respecta a la operatividad y funcionamiento de las redes de amigos.

Como vemos existen importantes antecedentes en los que los músicos gestionan su propia obra en colectivos de distinto tipo -sellos, cooperativas, etc. En años recientes, esta es una tendencia extendida para la música emergente producida en los centros urbanos de la Argentina, y particularmente en la zona metropolitana de Buenos Aires. Algunos trabajos recientes (Ochoa 2003, Yúdice 2008, Fouce 2010) permiten inscribir esta situación en una tendencia global en el incremento del número de emprendimientos independientes y de sus ventas, una consecuencia, en buena medida, de la disminución de los costos en las tecnologías de grabación y de la reconfiguración de la industria musical.

En las dos últimas décadas, los sellos discográficos participan de esta tendencia de crecimiento de organizaciones dedicadas a la producción y gestión de música. En el contexto local, el trabajo de Palmeiro (2005) documenta para una época relativamente anterior a esta investigación más de setenta sellos discográficos activos en la ciudad de Buenos Aires, a la que considera el nicho discográfico argentino por excelencia. La mayoría de ellos tienen menos de quince años de antigüedad, lo que indica una fuerte correlación entre su nacimiento y los avances en materia tecnológica, lo cual, sumado al peso sobrevaluado de la década del 90, abarató considerablemente los costos de producción de la música. Vecino (2011) y Lamacchia (2012) coinciden en señalar fines de la década del 90 como un período de multiplicación de pequeños y medianos sellos discográficos. Vecino (2011) sitúa entre estos a EPSA Music, Acqua Records, Ultrapop, sellos que mis interlocutores en Concepto Cero reconocían como parte relativamente central de la 
“industria”, junto a Índice Virgen, ZZK Records, Estamos Felices y Mamushka Dogs Records, más cercanos a nuestro caso en cuanto a estructura de gestión aunque también diferenciados. De la misma manera, Lamacchia (2012) clasifica en el mismo grupo a Melopea, Acqua y Laptra. Desde el punto de vista de mis interlocutores en Concepto Cero, los dos primeros estaban más vinculados a la "industria", mientras el tercero era un sello platense de su mismo nivel. El trabajo ya citado de Vecino reconoce la heterogeneidad entre estos sellos discográficos en cuanto al tamaño del catálogo, el soporte en el que editan sus discos y las estrategias de formación de catálogo. Acuerdo en estas distinciones pero creo que lo explica estas series heterogéneas es el hecho de que esta literatura opera una falsa sinonimia entre sellos discográficos y sellos musicales, específicamente entre sellos discográficos independientes y sellos de amigos como los descritos.

Es claro que los sellos gestionados entre amigos no agotan su papel en la música en la edición discográfica y las actividades asociadas a ella. Estos sellos resultan cualitativamente distintos a otros sellos independientes que operan en el país, generalmente empresas de diferentes tamaños con una estructura de gestión más o menos consolidada. Los sellos de amigos no se pueden entender cabalmente bajo el concepto de empresa, el cual es usado por ciertos abordajes locales para comprender a los sellos independientes locales, por ejemplo Palmeiro (2005), aunque reconoce que no siempre están constituidas como tales frente al fisco. Las describe como compañías productoras de fonogramas que no son propiedad de las grandes transnacionales y que tienen una estructura simplificada, menor tamaño y escaso poder financiero en relación a ellas. Piensa a sus propietarios y promotores como pequeños ejecutivos, muchas veces faltos de profesionalismo y restringidos por lo tanto en sus capacidades de acción dentro de la industria de la música. En mayor o menor medida, estas compañías discográficas relevadas por la bibliografía asumen la producción del material, la prensa, la promoción, la representación de artistas, la organización de eventos y hasta la propiedad de estudios de grabación, todas áreas de diversificación empresaria aisladas por Luchetti (2007) para los productores fonográficos "independientes", concentrados mayormente en la capital del país.

También para el contexto local, Corti (2007) propone dos modelos dominantes en las redes del disco independiente: el del productor/empresario de riesgo que asume la producción del material, por lo general, pero no siempre, a partir de sellos con una fuerte 
política de mercado, y el de los sellos que ofrecen la apoyatura comercial, legal y de distribución, quedando a cargo del artista la producción y financiación del disco. Los casos pioneros de Mandioca para el rock y de Melopea para la música popular son propuestos por Corti como ejemplos que responden a los lineamientos del primer modelo -podríamos agregar a los sellos Trova, Redondel y Epsa Music, entre otros- Mandioca se proponía como una editora de discos alternativa que tomara en cuenta las propuestas de los músicos, conservara cierto control del proceso de producción desde la grabación hasta la distribución y conjugara la perspectiva de ventas con los criterios de calidad y pertenencia al mundo del rock, ya que las grabadoras oficiales de la época aún no podían ver en él más que un dudoso negocio para no hablar de la incomprensión que manifestaban con respecto a sus concepciones estéticas (Díaz 2005). Como declara su creador, Jorge Álvarez, Mandioca surgió "gracias a la negativa de los grandes sellos" (Álvarez 2013: 91). La infraestructura de Mandioca era muy pequeña, el proyecto se financiaba a partir de créditos y pagarés y sus socios no cobraban salarios, ya que procuraban, por el contrario, una reinversión permanente destinada a nuevos grupos y sus proyectos (Collado 2010). Al contrario de Mandioca, que quebraba a mediados del año 1970, luego de dos breves pero intensos años de actividad en los que intentó el masivo éxito de ventas de alguna placa para asegurar su supervivencia, sellos como el que acá estudiamos asumen en comparación menos riesgo, lo que les permite un mayor dinamismo y el funcionamiento con rendimientos económicos que para otros resultarían un verdadero fracaso comercial.

Palmeiro (2005), Luchetti (2007) y Corti (2007) analizan experiencias de producción musical y discográfica con unos parámetros y una idea general de sello que pertenecen al paradigma del imperio de las grandes compañías discográficas, en el que el disco inicia el ciclo de la música. Es de notar que en los últimos años este panorama fue rápidamente redefinido por las nuevas tecnologías incluso en el ámbito de las majors: las grandes disqueras dejan de ser compañías discográficas para pasar a ser compañías de música (Lamacchia 2012: 147) habida cuenta de la multiplicación de las demandas de música en el capitalismo contemporáneo: de la publicidad a la música para videojuegos, pasando por la música para los centros comerciales y supermercados.

A diferencia de estos casos estudiados por la literatura, referidos como sellos discográficos independientes, los nuevos sellos musicales que surgen en la zona 
metropolitana entre los años 1998 y 2010 no suelen proveer a los artistas de estudios de grabación, equipos, instrumentos o recursos humanos, como establece Vecino (2011) ${ }^{67}$ al respecto de los mundos del "rock independiente", la "cumbia electrónica" y el "nuevo tango" que se multiplican en la CABA en dicho período. No sólo eso: los sellos de amigos que conocimos no poseen las estructuras típicas de gestión que permitirían hacerse cargo de estas y otras dimensiones de la actividad, como la promoción o la distribución, pero sin embargo no resultan ajenos a dichas tareas típicas, ya que funcionan como centros de redes de sociabilidad de producción musical en las cuales dichas actividades, pero también otras que un observador externo separaría de la música, tienen lugar.

En este diálogo con la bibliografía especializada fue volviéndose cada vez más evidente que al caso en estudio le quedaba grande la categoría de sello discográfico independiente citada en la bibliografía, a la vez que la desbordaba. Es cierto que, en una lectura superficial, la descripción que hemos hecho de los sellos de amigos puede ser confundida en dicha matriz discográfico-céntrica para leerse como sellos discográficos simplemente más pequeños y/o "amateurs". Pero aún cuando los músicos usen la misma palabra (sello) y realicen actividades parecidas a las que refieren estos autores, construyen una realidad diferente. No debe connotarse entonces la noción de sello como instancia del mercado y la industria discográfica clásica, falsa sinonimia muy común en la bibliografía específica. Hablar de sellos en este contexto etnográfico remite menos a las instancias de grabación, contrato, difusión que a una amplísima serie de actividades por las que se produce la organización social de la música: los criterios de apreciación, evaluación y legitimación de la música, la vinculación con otras artes, la valorización monetaria de la música, se producen hacia el interior del sello. Es por estas razones que el sello es "un comodín para decir un montón de cosas".

Ahora puedo volver a las experiencias de autogestión que mencionaba como antecedentes en páginas anteriores, dado que los músicos con los que nos relacionamos insisten en que en sus prácticas de producción y gestión musical hay cambio y novedad. ¿En qué se diferencian las prácticas de auto-edición de MIA, Los Redondos, las bandas del rock chabón y los sellos de música indie de los años noventa con respecto a las que acá

\footnotetext{
${ }^{67}$ Este autor continúa las referencias a lo discográfico para describir sellos que desde mi perspectiva ya operan con una lógica ampliada y no centrada en el disco. No obstante, su trabajo incorpora algunas de las novedades que analizo para el caso de Concepto Cero y sus sellos amigos.
} 
estudiamos? Sin desconocer la heterogeneidad interna de esta serie, e incluso con la precaución que exige la falta de estudios completos sobre estos fenómenos, puedo ensayar una primera respuesta que seguiré elaborando a lo largo de estas páginas.

En primer lugar, resulta claro que la implantación y significado que estas instituciones tienen al interior de la escena es diferente. En el período contemplado por la investigación la multiplicación de estos colectivos es notoria: mientras mis interlocutores en el año 2009 no reconocían más de cuatro sellos activos en La Plata (Mandarinas Records, Laptra, Cala y Cloe Discos), en el año 2013 podían enumerarme por lo menos nueve. A Laptra y Mandarinas Records, que seguían en funcionamiento, le sumaban Uf Caruf, Dice Discos, Tomas del Mar Muerto, Serial Música, Choco Discos, Tsunami Records, Unclan Discos y, entre otros, el propio Concepto Cero. Este crecimiento fue acompañado de una alta visibilidad en la ciudad y en la prensa -tanto local como nacional, parte de iniciativas independientes o de grandes empresas mediáticas. Es por este motivo que las organizaciones musicales que acá estudiamos no pueden ser clasificadas bajo la vieja categoría del under, término que no es usado por sus integrantes para referir a sus prácticas musicales. Como plantea Lamacchia (2012: 201) en la actualidad los conceptos "under" e "independiente" han dejado de ser sinónimos. Si bien esta investigadora relaciona este hecho a la experiencia de grupos y solistas que se mantienen independientes y logran una gran convocatoria, la condición de esa situación es más general: se ha complejizado la relación entre las distintas escalas de producción, difusión y consumo de la música.

En esta complejización, las nuevas tecnologías son centrales: Reynolds (2009: 203) entiende que desde la década del 2000 la luz de sobre-exposición de la web implica que cualquier cosa que tenga presencia online ya no puede sentirse underground del mismo modo en que lo hacían sus precursores de la era de los fanzines. Por lo tanto, los llamados márgenes del negocio se disuelven continuamente a causa de Internet pero también de los trastornos económicos de la industria musical. El llamado mainstream ya no está rodeado del underground, sino de escenas que "simplemente no venden muchos discos" (Reynolds 2009: 205). Claro que no compartimos el desencanto que Reynolds experimenta ante un nuevo falso under y "cuasi bohemia": creemos que estas escenas implican mucho más que su marginalidad económica. Son la muestra de un "desdoblamiento de las escenas 
musicales que hace aparecer un segmento novedoso, denso y relevante", causa y consecuencia de una serie de novedades en el panorama tecnológico y estético (Gallo y Semán en prensa).

Esta "lógica cambiada" es referida por varios de los músicos con los que conversé durante estos años, como me decía uno de ellos: "Si hoy estuviésemos en los noventa, Él Mató $^{68}$...ya sería como Attaque 77, ponele. Una banda así. Porque en esa época el mercado estaba re concentrado, entonces había "la banda que despegaba" (...) y el resto ahí abajo". En un taller brindado por el Ministerio de Cultura al que fuimos con Concepto Cero, el periodista especializado en rock Eduardo Fábregat nos decía convincente: "Lo que hoy podemos entender como under no es under, no está debajo de nada, es visible, y de hecho es muy visible... el under de los ochenta en la Argentina no se va a volver a producir más". En esa época "vivir por fuera de las grandes ligas significaba vivir en el anonimato", lo cual hoy es prácticamente imposible. Como desarrollo en el próximo capítulo, la noción de la novedad de estas prácticas con respecto a otras épocas estructuraba varios discursos que los músicos con los que traté tuvieron a mano. Los cursos y capacitaciones y las lecturas de manuales, notas periodísticas y otros textos producidos en el campo, incluyendo mi tesis de maestría, funcionaron para los músicos con los que traté como teorías para comprender dicha novedad.

En segundo lugar, los derroteros de sellos como el estudiado nos muestran que actualmente emprendimientos iniciados desde el "hazlo tú mismo" pueden proponerse derivar, de manera sustentable a nivel económico y con relativa autonomía de las grandes discográficas, en estructuras de producción y gestión musical que exceden ampliamente la edición de discos. De la misma manera, por más que encontremos en estos precedentes músicos que se hicieron cargo de la gestión, estas habilidades no resultaban tan exigidas y tan extendidas como para los músicos contemporáneos. A partir de los desarrollos del capítulo IV, se verá que tampoco eran tomadas como objeto de perfeccionamiento y reflexión, tal como hacen los músicos emergentes con los que investigamos. Encontraremos al interior de sellos como Concepto Cero perfiles de músicos difíciles de clasificar sino es con nuevas categorías.

\footnotetext{
${ }^{68}$ Refiere a Él Mató A Un Policía Motorizado, una banda de La Plata con la que se suele ejemplificar el modelo de consagración actual de la escena independiente o emergente.
} 
Los sellos musicales donde la gestión y producción musical se resuelve en el marco del grupo de amigos que se han desarrollado en años recientes en La Plata, pueden comprenderse como un punto de conexión entre las dimensiones identitarias, las musicales y, por último, las referidas a lo que se asume como gestión e incluye, desbordándolo, a lo estrictamente económico. En el primer sentido, los sellos permiten articular sentidos de pertenencia y fronteras de sensibilidad que delimitan quiénes hacen tal música y/o se organizan de tal o cual manera, quiénes ostentan determinado estilo -en un sentido no meramente estético, como se verá en el capítulo $\mathrm{V}$-, quiénes se reconocen en determinados espacios de la ciudad, entre otros aspectos. Así, a partir de definiciones que se han desvinculado fuertemente de los criterios de género musical, el sello produce una diferencia en un contexto de sobreoferta musical.

En un segundo sentido, el sello refiere a las redes en las cuales se producen formas específicas de apreciación, evaluación y legitimación de la música. Al haber orientado la investigación desde la consideración de que la propia reflexividad de los sujetos era central para comprender sus filias musicales y estéticas, vuelvo en este punto a una observación de Hennion. En uno de sus trabajos más recientes, Hennion (2012: 226) sostiene cómo en la selección de las más variadas músicas, en el desarrollo de técnicas de escucha, en la construcción de una tradición de antecesores y de ídolos, en la propia práctica con el instrumento y con los dispositivos de producción musical, los grupos de pares construyen su propia sociología del gusto. Se trata de un vínculo con la música que puede producir una legitimidad propia y que, sin dejar de alterizar con el canon, no tiene necesidad de responder a él, como desarrollaré en particular en el capítulo $\mathrm{V}$ con respecto a la forma en que estos músicos entienden la originalidad y la innovación en la música.

En un tercer sentido, el sello es un dispositivo de producción y gestión de los proyectos y obras musicales, donde se incluye la dimensión de la obtención de ganancia y de la sustentabilidad económica de las prácticas estéticas. Sin embargo, estos sellos no responden al modelo de una empresa, sea esta una organización racionalizada y altamente estructurada o una PyME con menor capacidad, ni tampoco intentan meramente emular, sin éxito, dichos modelos. Más bien el sello es una red en la que, a partir del agenciamiento tecnológico, estos músicos y artistas asumen la práctica de la gestión -el encarar de manera activa y diferente a las generaciones de músicos anteriores la relación con el mercado e 
instituciones, especialmente estatales, que median con recursos- como un momento constitutivo y prácticamente irrenunciable de su práctica estética. En este contexto, la posibilidad de operar a bajo costo relativo, condición resultante de la masificación y abaratamiento de las tecnologías musicales, resulta un impulso decisivo.

Como institución en el mundo musical emergente analizado, el sello abarca las distintas instancias que son divididas tradicionalmente como producción, distribución y consumo. Mirado bajo este aspecto, el sello es un grupo de amigos dedicado a la música que funciona no meramente como rúbrica, sino como núcleo de aprendizaje en la gestión de la propia práctica musical, activador de un mercado -básicamente local y de la zona metropolitana-, recurso de comunicación y distinción, conector con redes más amplias de producción cultural. En el análisis de la forma sello interesa trascender el economicismo implícito de algunos estudios que ven en la música sólo una forma más de la mercancía. Desde ya: la música producida se constituye en una mercancía pero considerar este carácter como determinante de todas las dimensiones de un fenómeno complejo, donde se incluyen moralidades en la relación con la música, formas de gestión, modos de producción, relaciones con el trabajo, construcción de afectividad, resultaría empobrecedor y reduccionista, más aún cuando esas dimensiones se encuentran vinculadas a una reconfiguración de los mercados musicales y de las condiciones de mercantilización de los productos en la música (Yúdice 2002 2008, Fouce 2010, entre otros).

En relación al estado de las investigaciones sobre estos temas, cabe puntualizar que prestar atención a un sello de esta clase cuestiona una particular segmentación del análisis que el mundo del rock nacional y de otras músicas asociadas a lo juvenil había permitido: estudiar por un lado los músicos, por otro lado los públicos, por un lado la producción, por el otro la recepción, como también la separación del análisis entre las dimensiones estéticas y morales frente a las económicas. Justamente, la bibliografía académica producida localmente sobre emprendimientos discográficos, sellos musicales y otras experiencias de gestión y producción musical resultaba hasta hace unos pocos años muy acotada. Pujol (2013) ha advertido acerca del lugar subalterno de las realidades discográficas y organizacionales en el estudio de la música en la Argentina. En el caso de emprendimientos musicales como Concepto Cero esto sucede en parte porque su historia estalla en el período que nos ocupa: es en los últimos diez años que, a partir del agenciamiento tecnológico y de 
transformaciones en la forma que los jóvenes tienen de vincularse con la música, se verifica el crecimiento de organizaciones musicales de esta clase. Asimismo, existe una situación más general a nivel de las orientaciones teóricas con las que se investiga estos temas: la importancia otorgada bien a los artistas, a las obras o a los públicos, descuidan el papel de las mediaciones que con Hennion (2002) consideramos constitutivas de la música.

Justamente, el sello musical tal como lo he descrito es una institución de mediación que los músicos construyen y que les habilita específicos cursos de acción y de vínculo con la música. En este capítulo, describí el momento inicial de Concepto Cero como sello musical emergente a partir del despliegue del sinfín de mediaciones que lo hacían funcionar. Descubrí redes de cooperación que conectaban personas, recursos, tecnologías y saberes, necesarios para producir y gestionar música en un contexto de desdoblamiento de las escenas musicales. Distinguí este tipo específico de sello tanto de los sellos discográficos tradicionales como de otras iniciativas de gestión propia de la música a fin de ponderar la novedad que mis interlocutores se imputan. Una vez en Concepto Cero y atenta a su dinámica de producción, su funcionamiento me obligó a prestar atención a las conexiones que el sello tendía hacia su exterior: con un conjunto de otros sellos musicales de La Plata, con políticas públicas concretas, con otras bandas independientes, con ciertos managers y organizadores de eventos. Avanzaré sobre estas redes y su sentido para esta experiencia de producción y gestión musical emergente en el próximo capítulo. 


\section{Capítulo III: Entre amigos, hostigadores y aliados: el trazado de redes con otros actores de creación y gestión estética}

Entre el 27 y 29 de septiembre del año 2012 se realizó en el Teatro Argentino el pre MICA La Plata, un encuentro previo de cara al MICA 2013, organizado por la Secretaría de Cultura de la Presidencia de la Nación ${ }^{69}$ y el Instituto Cultural bonaerense. La sigla, correspondiente a Mercado de Industrias Culturales Argentinas ${ }^{70}$, reunía "diferentes actividades de las industrias culturales con el objeto de generar negocios, intercambiar información y presentar su producción a los principales referentes de todo el mundo"71. Junto a la música, los sectores escogidos para participar fueron: artes escénicas, audiovisual, diseño, editorial y videojuegos. Corrieron tres días intensos para Concepto Cero y los amigos que habían hecho durante ese año a partir de la conformación de TICA, una red de sellos de la provincia de Buenos Aires.

Varios de los músicos de estos sellos habían viajado de ciudades como Mar del Plata, Rosario y CABA para asistir a las rondas de negocios -en las que se habían inscripto con anterioridad-, los talleres, conferencias y seminarios, además de los showcases $^{72}$. Hospedados en las casas de Nicolás, Cristóbal y otros músicos integrantes de sellos platenses, aprovecharon también para participar de fechas en la ciudad, ya que el evento tomó parte del fin de semana. Nicolás fue panelista de una conferencia titulada "Colectivos culturales, nuevas redes de circulación a nivel nacional. Red de productores"73 en la que

\footnotetext{
${ }^{69}$ Como ya señalé en una nota del capítulo I, en mayo de 2014 la secretaría fue jerarquizada al rango de Ministerio. Es por ese motivo que el capítulo refiere a ambas denominaciones, dependiendo de qué momento del período se trate.

${ }^{70}$ Organizado por la Secretaría de Cultura de la Nación, conjuntamente con el Ministerio de Industria; el Ministerio de Relaciones Exteriores, Comercio Internacional y Culto; el Ministerio de Trabajo Empleo y Seguridad Social; el Ministerio de Turismo, y el Ministerio de Planificación Federal, Inversión Pública y Servicios, tuvo su primera edición en el año 2011. Durante el 2012 se sucedieron distintos pre MICA -en Mar del Plata, Formosa, Tucumán, entre otras ciudades del país- a fin de preparar a los artistas y emprendedores para el pre MICA nacional que se realizó en la CABA durante el 2013.

${ }^{71}$ De acuerdo a datos de su página oficial: http://www.mica.gob.ar/institucional/ (consultado: 24/04/13).

${ }^{72} \mathrm{Se}$ trata de un concierto breve, de unos veinte minutos de duración, cuyo objetivo es mostrar lo considerado mejor y más representativo de un artista.

${ }^{73}$ En la charla también participaron: Cecilia Salguero (Red de Productoras), Carlos Sidoni (TRAMA), Paula Rivera (PR), Francisco Corcho Benítez (Cecual Chaco). Fue armada y presentada por Fer Isella -músico y gestor, coordinador del sector musical del MICA- y moderada por el periodista Gabriel Plaza.
} 
representó a TICA Red. Excursiones Polares tocó en uno de los showcases del jueves; bandas de TICA grabaron un tema en el Estudio MICA; músicos de TICA expusieron en otras conferencias, mientras otros amigos del sello, como Tormenta, participaron de las actividades del sector de diseño; además, asistieron funcionarios estatales con los Concepto Cero se había relacionado durante todo ese año.

En la conferencia mencionada "las redes" fueron un tema recurrente de los panelistas, quienes contaron cómo habían formado las propias y qué significaban para ellos; además, alrededor del tema hubo una reivindicación de los asistentes, quienes en sus intervenciones aseguraban también "trabajar en red". Si bien el encuentro tuvo una convocatoria superior a las cincuenta personas, muchas se conocían: a algunos acompañantes del panel Nicolás los había tratado en otros encuentros pre MICA regionales a los que había asistido ese año; entre los asistentes se encontraban músicos, comunicadores, gestores y productores que habían participado ese año de Recalculando, un programa lanzado por la Secretaria de Cultura para profesionalizar la música independiente.

En este capítulo relataré una aventura de redes, capacitación y trabajo que vinculó la práctica musical de Concepto Cero con distintas políticas públicas y funcionarios estatales, sellos musicales, organizadores de eventos y empresas. No describiré todos los vínculos que el sello tenía en el período, sino un movimiento que va desde el sello hacia su afuera entre los años 2012 y 2013. A partir del despliegue de las conexiones de los músicos, mostraré la centralidad que adquiría la noción de red y discutiré el sentido que adquiere para ellos. En particular, seguiré la conformación cruzada de TICA Red y del punto La Plata del programa estatal Recalculando a fin de ponderar el encuentro entre los músicos y la política pública. Este despliegue también me permitirá avanzar sobre el sentido de la profesionalización musical, cuestión protagónica para el capítulo IV.

\section{Ampliando redes}

Atravesábamos el mes de febrero de 2012 y La Plata era una ciudad desierta que recién comenzaba a repoblarse con los grupos de estudiantes universitarios que volvían a estudiar y rendir exámenes finales, y otros que se instalaban por primera vez para realizar los cursos de ingreso ofrecidos por las distintas facultades de la UNLP. Faltaba al menos un 
mes para observar el retorno a un ritmo normal de actividades: con él volvería a iniciarse lentamente el ciclo de la escena independiente de la ciudad de La Plata, asociado al calendario universitario. Pero Nicolás ya estaba trabajando y me invitó a su casa para "hablar de las novedades del sello" y "contarme algunas cosas".

A partir de este año, discontinuadas las reuniones grupales del sello por los distintos alejamientos en el grupo de amigos presentados en el capítulo anterior, visité con cierta regularidad a Nicolás en la casa en la que vivía con su madre, muy cercana al departamento que yo alquilaba por entonces, en las inmediaciones de Plaza España. Él me repetía la utilidad que encontraba en contarme sus nuevos proyectos o los avatares de los proyectos en curso, "así voy pasando en limpio". Varias veces fui a su casa de mañana, con un paquete de medialunas, para tomar un café y escucharlo hablar, casi siempre del trabajo en el sello, relato en el que incluía también las dimensiones afectivas y emotivas que el trabajo grupal involucraba. El horario de mañana, si bien no exclusivo, era usualmente el que terminábamos acordando: la agenda de Nicolás empezaba a apretarse y solía tener reuniones con bandas o con otros miembros del sello más tarde.

En esos encuentros de febrero y marzo del año 2012, Nicolás estaba focalizado en rearmar de alguna manera las redes del sello: listaba a los integrantes que tenían "pilas para seguir", entre quienes contaba al Tata, a Cristóbal, al Pampa y a los fotógrafos Pancho y Cata. Ángel, músico de Excursiones Polares y Damián, solista que había producido discos del catálogo también se sumaban ese año a tareas de producción, gestión y comunicación del sello, con un protagonismo ascendente a lo largo del período. Ángel contaba con unos diez años más que Nicolás, había pasado por varios trabajos ajenos a la música, como ser operario de fábrica. Era graduado universitario de la carrera de Comunicación y estaba cursando una maestría en sociología de la cultura en la Universidad Nacional de San Martín, mientras era empleado administrativo en el Estado. Al término de este trabajo etnográfico había abandonado el posgrado y mientras seguía trabajando en el Estado, se había vuelto "socio" de Nicolás y proyectaba dedicarse sólo a la música. Por su parte, Damián había sido compañero de Nicolás en la facultad, donde se recibió de Licenciado en Composición Electroacústica y se desempeñaba como docente. Durante el período tuvo una beca del IUNA para hacer un posgrado en artes, y luego se presentó al CONICET. Había sido el productor de algunos materiales de Brahmán Cero y Excursiones Polares. 
Además, Nicolás me contaba que había empezado a trabajar para Mostruo -un grupo de rock de reconocida trayectoria en la ciudad- en la organización de fechas concretas y en una estrategia general de presentaciones y de comunicación en las redes sociales. De esa manera, había coincidido con Luli, el baterista de esta banda, en un interés por el desarrollo de la escena de La Plata, de mayores vínculos entre los distintos sellos y bandas de la ciudad, como también entre estos últimos y el Estado. En marzo, Nicolás comenzó a introducirme en las conversaciones que mantenía con Luli ${ }^{74}$ junto a Cuchi y JP, los responsables de Ciudad Alterna ${ }^{75}$, un encuentro de cultura rock independiente e interdisciplinario realizado desde el año 2010 en La Plata. Nicolás valoraba en uno de nuestros desayunos la presencia de estos distintos actores: "Ciudad Alterna está bueno porque Ciudad Alterna es como un festival de La Plata y que no hay otro igual...y Luli de Monstruo está bueno porque el chabón trabaja en cooperación internacional y tiene como muchos años de experiencia y también él ahora está trabajando con los pibes de Uf Caruf..."

Al mismo tiempo, Nicolás había comenzado a relacionarse con un productor de la Secretaría de Cultura de la Nación, Martín Mena, a quien había conocido en Brasil en diciembre del año anterior. Nicolás había viajado a un congreso artístico con sede en la capital brasileña junto a una de sus amigas de Tormenta para exponer el proyecto de Concepto Cero y también el de TriMarchi, ya que los organizadores del congreso de diseño le habían dado dinero para viajar. Había llevado discos, calcomanías y folletos de Concepto Cero, además de ejemplares de trabajos de Tadeo y el Pampa. Al mismo tiempo, había aprovechado para visitar la casa de Fora do Eixo (FdE) de la ciudad de San Pablo, donde

\footnotetext{
${ }^{74}$ El baterista de Mostruo. Era un músico de "otra generación”, más grande en edad que los de Concepto Cero y sus sellos amigos, que trabajaba en la administración de la UNLP.

${ }_{75}$ Tal como plantea Cingolani (2015: 2) en un trabajo íntegramente dedicado a este evento, Ciudad Alterna es definido por sus organizadores - comunicadores sociales de la UNLP- como "encuentro" a los fines de "distanciarse de la idea de festival, en tanto consideran que éste tiene una lógica de acumular bandas de rock sin más objetivo que ese. Según su perspectiva, un encuentro es libre, gratuito, sin fines de lucro y además, en él no conviven únicamente bandas musicales, sino un conjunto de disciplinas artísticas que conformarían lo que ellos llaman 'cultura rock". En efecto, a lo largo de sus tres días de duración, el evento incorpora otras actividades estrechamente vinculadas a la música rock: exposiciones de fotografía y artes visuales, proyecciones de videos y documentales, presentaciones de libros, conferencias y entrevistas a músicos reconocidos.

${ }^{76}$ Como me enteré después, Luli estaba tocando para un proyecto musical del sello. Uf Caruf se definía como un "sello copyleft" plenamente de amigos y con una orientación a la canción. Se había iniciado, de hecho, a partir de un ciclo de recitales de un grupo de cantautores llamado Tocate Mil. Entre sus artistas al momento del trabajo etnográfico, figuraban: Lautaro Barceló, Pablo Matías Vidal, Miro y su Fabulosa Orquesta de Juguete, Orquesta de Perros, Primer Hombre Internacional, La Teoría del Caos.
} 
conoció a Martín. Autodefinida como una red de productores culturales, FdE sería ampliamente referenciada durante todo el año 2012 a partir del concepto de red, la importancia de las tecnologías digitales y una relación novedosa con el Estado ${ }^{77}$. Nicolás volvería impactado de la organización de FdE y de lo "pro" que eran sus miembros en lo que respecta a la gestión cultural. Pero no era el único impresionado: a lo largo del año pude comprobar que algunos músicos de TICA, periodistas y gestores culturales con los que Concepto Cero comienza a relacionarse también conocían y hacían valer esta experiencia para compararla con la suya ${ }^{78}$.

En uno de aquellos encuentros de mañana, Nicolás contaba de la siguiente manera las consecuencias de conocer FdE: “...nos juntamos con Martín que es de Secretaría de Cultura de Nación. Él es como un productor, o sea tiene la función clara de hacer (...) quedó muy manija de Brasil, como de ese laburo de red de redes, entonces, nosotros nos empezamos a juntar con un grupo de gente en Buenos Aires, para ver, qué sé yo, qué se puede hacer acá”. Luego de un par de reuniones en la Capital Federal, Nicolás decidió que "era más interesante venir a La Plata" y comenzar a intercambiar sobre este proyecto con músicos, gestores y artistas de la escena local. En ese contexto, comienza a reunirse con los responsables de Ciudad Alterna y con Luli, grupo al que más adelante se unirían Lautaro y Juan $^{79}$, dos músicos de Uf Caruf, y Julieta, una amiga y gestora cultural recibida en la Universidad Nacional de Tres de Febrero (UNTREF).

A inicios del mes de abril fui invitada por Nicolás a una de estas reuniones, en la que estaban presentes Cuchi de Ciudad Alterna, Luli, y Cristóbal. Las conversaciones ya

\footnotetext{
${ }^{77}$ FdE es un movimiento artístico cultural brasileño que inició sus actividades en el año 2005. Está construido por una serie de colectivos que se articulan entre sí por el uso de las tecnologías digitales. La red tuvo su comienzo en la periferia brasileña, fuera del eje geopolítico Rio de Janeiro/San Pablo que congrega los medios masivos, el poder político y la mayoría de las producciones culturales del país. FdE surge en un contexto de expansión de las políticas públicas aplicadas a la cultura, que promovieron en Brasil la articulación entre estas redes y el Estado, generando lo que Irisarri (2015), a quien sigo en su descripción y análisis de la red, denomina "prácticas de gestión compartida".

${ }^{78}$ Los brasileños también realizaban visitas a la Argentina. Irisarri (2015: 104) relata que cuando se insertó en las redes de FdE dos líderes de la organización venían de nuestro país. A lo largo de mi trabajo de campo se repetirían estas visitas: productores de FdE vinieron a la presentación del programa Recalculando en el MICA 2013. Asimismo, en el marco de una charla titulada "Experiencias de desarrollo de la música emergente en América del Sur", un representante de Fora do Eixo disertó en uno de los encuentros del programa Recalculando que se presenta en este capítulo.

${ }^{79}$ Lautaro Barceló, en ese momento músico de Orquesta de Perros. También participaba en otras bandas del sello y contaba con proyectos solistas y en banda como "Canto el cuerpo eléctrico". Juan Artero, comunicador social y músico, se desempañaba tanto en bandas del sello como en la docencia en la Facultad de Periodismo y Comunicación Social de la UNLP.
} 
estaban bastante avanzadas y daban por descontados ciertos acuerdos. Ellos creían necesario empezar a "formar" a los participantes de la escena, y al mismo tiempo lograr que estuvieran más conectados entre sí. En las reuniones a las que asistí se intercambiaba sobre la dinámica de los pre MICA regionales que estaban desarrollándose en el todo el interior del país, las políticas del municipio en relación con la música local, y varias ideas para realizar capacitaciones y redes. Los comentarios en la reunión dejaban entrever una concepción del músico pro-activo que se hacía responsable de la gestión de su propia música. En este sentido, Nicolás criticaba a un grupo de músicos auto-convocados que reclamaban por entonces al Estado municipal lugares para tocar y caché; y decía: “...creen que el músico se tiene que sentar ahí, estar esperando que le digan vení a tocar, tiene que tocar, ir, que le paguen e irse, me parece que eso está obsoleto digamos, si nosotros no conseguimos que el músico trabaje para las otras bandas y que el músico sea su propio promotor y que se yo, no se puede llegar muy lejos". Que el músico trabaje para otras bandas y sea su propio promotor suponía una red de artistas en contacto entre sí, a la vez que una serie de actividades para el músico que excedían lo estrictamente musical.

Estos intereses no eran nuevos ni remitían sólo a la experiencia brasileña. Durante el año 2011 Nicolás y Matías habían asistido a una serie de talleres en el Centro Cultural Islas Malvinas sobre diversas temáticas asociadas a la gestión de la música, organizados por el Instituto Cultural de la Provincia de Buenos Aires. En cada encuentro se daban cita dos o tres disertantes. En el taller al que los acompañé, María Zago ${ }^{80}$ brindó una conferencia llamada "Management, autogestión cooperativa y desarrollo de artistas en el exterior"; Nicolás Wainszelbaum ${ }^{81}$, por su parte, propuso una charla titulada "Industria de la música: actores, cadena y reformulación del negocio"; por último, Miguel Payo ${ }^{82}$ disertó sobre “Herramientas de gestión aplicadas a los Emprendimientos de Base cultural”. La mayoría de los talleres brindaban herramientas de comprensión de los cambios en el negocio de la

\footnotetext{
${ }^{80}$ La propaganda de la actividad presentaba a María Zago como una "gestora cultural, con estudios en artes (UBA) y comunicación visual (UNLP)" quien "hace doce años lidera proyectos en el área de la música en Buenos Aires y el extranjero". En la charla, ella hizo especial énfasis en su trabajo en la gestión cooperativa de la Orquesta Típica Fernández Fierro.

${ }^{81}$ Nicolás Wainszelbaum era presentado como "Sociólogo (UBA), Director de Industrias Creativas del Instituto Cultural de la Pcia de BsAs."

${ }^{82}$ Por su parte, Miguel Payo era presentado como "Economista, docente de la Facultad de Ciencias Económicas de la UNLP y Capacitador del programa de apoyo a emprendedores en Folklore Buenos Aires".

Todos los datos recogidos en: http://www.ic.gba.gov.ar/prensa/noticia.php?idnoticia=17139 (consultado $16 / 09 / 11)$.
} 
música y de gestión en este escenario transformado. Estaban dirigidos no sólo a los músicos sino a personas vinculadas a ella, como periodistas, managers, productores, programadores de conciertos, técnicos, responsables de sellos discográficos, gestores culturales, entre otros. Durante el taller mencionado arriba, Nicolás Wainszelbaum preguntó a la audiencia: “¿cuántos de acá son músicos?”. La mayoría de los asistentes levantó la mano, a lo que este replicó: "Veo algunas caras conocidas". No obstante estos músicos no solían pertenecer a la escena de la que mis interlocutores se consideraban parte: a comienzos del 2012, Nicolás entendía que “...la gente no responde (...), menos el rock digamos, o sea, yo soy el único chabón que responde a cierta banda de rock que aparece en unas cuestiones que son más... institucionales como puede ser una charla así, que para mucha gente te juro que le hubiera servido pero lo invita el Instituto Cultural entonces qué te importa”.

Además de los talleres del Instituto Cultural, había conocimiento entre estos músicos y gestores de otro antecedente para las capacitaciones: el programa Recalculando que llevaba adelante Martín Mena desde la entonces Secretaría de Cultura de la Nación. A Martín lo conocería meses después: encargado de la programación de las bandas de Tecnópolis $^{83}$, no llegaba a los cuarenta años y era la primera vez que se encontraba "trabajando para el Estado", contando con una trayectoria como manager de bandas de rock “alternativo" en los años noventa, además de una circulación en FM La Tribu, un colectivo de comunicación alternativa radicado en la Capital Federal reconocido por su trayectoria y activismo cultural. Estos artistas y gestores que se reunían con Nicolás pensaban que el Estado no tenía que tener un papel en la formación de la "masa crítica" -tal era la expresión que usaban-: en las reuniones sólo se lo nombraba a partir de estas políticas antecedentes y como interlocutor de una red de músicos formada sin su intervención, exactamente como sucedía en el modelo de Fora do Eixo. Nicolás me decía que lo ideal era que las capacitaciones "no tengan que salir desde el Estado digo (...) o sea si está el Instituto Cultural está, ponele que lo promueva el Instituto Cultural, pero que no surja desde ahí... porque la gente no responde".

De acuerdo a este diagnóstico, el grupo de Cuchi, JP, Luli, Lautaro, Juan y Nicolás creían que había que actuar como referentes y organizadores de encuentros de "formación"

\footnotetext{
${ }^{83}$ Se trata de una megamuestra de ciencia, tecnología, industria y arte emplazada en el Gran Buenos Aires, inaugurada en 2011 por la Presidencia de la Nación. La entrada es libre y gratuita. Ver: http://www.tecnopolis.ar/2012/
} 
o de "capacitación”. Además de la concepción del músico como un gestor responsable de su propia música, en las conversaciones se ponían en juego argumentos más inmediatos para impulsar las capacitaciones: en octubre de ese año tendría lugar en La Plata el pre MICA, al que planificaban "llegar con otros recursos y experiencias" a fin de "aprovechar mejor" el encuentro. La mayoría de ellos se anotarían en rondas de negocios, más orientados a "ver cómo es" y "aprender" que esperando compras efectivas de sus servicios. Cómo se hace un festival, cómo se registra un disco, qué son los derechos de autor y cuáles son los tipos de licencias se barajaban como posibles temáticas para esos encuentros de formación o capacitación. Ninguno de ellos sabía todavía cómo efectivizar esas capacitaciones pero sí que debían realizarse a partir de una red de bandas.

A tono con esta concepción, el objetivo era reunir hacia el interior de la escena de La Plata una "masa crítica": cada uno debía empezar a invitar a las bandas que conocía con el motivo de encontrarse y compartir las necesidades que tenían en común. Este plan surgía de la necesidad de obtener fuerza y representatividad. Nicolás afirmaba que ellos tenían que lograr hablar con cualquier empresa o con el Estado y poder decir que atrás de ellos había al menos 100 bandas. En cuanto a las empresas, además de compañías dedicadas al sonido $^{84}$, se pensaba principalmente en compañías de transporte. Los músicos participantes de estas reuniones coincidían en lo que me dijo uno de ellos: "Para que un montón de bandas vayan a tocar a otros lugares lo único que nos hace falta son pasajes, porque las movidas están y las bandas capaz no quieren ganar plata. Y hospedaje, también te pueden dar ¿entendés? Entonces capaz vas y cobrás lo mismo que una fecha pedorra, no sé, cobras 300 mangos. Pero si tenés un pasaje, le ahorrás un montón de gastos a la producción... ahí hace falta que haya mucha gente trabajando junta, como para poder ir a negociar". Agregaba en esta misma línea: "Digamos 'somos todos estos y este año queremos hacer esta cantidad de fechas', vamos a Urquiza y digámosle eso, a ver que nos dicen...”. La cuestión de la movilidad sería señalada en numerosas conversaciones entre miembros de TICA y en capacitaciones de Recalculando ${ }^{85}$. Más adelante, varios de estos músicos se

\footnotetext{
${ }^{84}$ Nicolás proyectaba que a partir de la red se pudieran compartir gastos de equipos de sonido para fechas grandes -ya que muchas veces se alquilan- o realizar convenios -ya que, al decir de Nicolás: "alquilar un sonido no es lo mismo que alquilar diez".

${ }^{85}$ Durante una reunión de Recalculando, unas productoras cordobesas contaron su experiencia al respecto: luego de conformarse como red habían pedido descuentos a las empresas de micros de larga distancia,
} 
presentaron a la convocatoria del Fondo Argentino de Desarrollo Cultural, una de cuyas líneas fue Movilidad, que el Ministerio de Cultura lanzó en el año 2014.

Al respecto de la red de bandas, mis interlocutores también recuperaban sus antecedentes. En la reunión a la que asistí enseguida se citó el caso de Ciberbia, una autodenominada "red de artistas" en actividad durante aquel año y asociada a Shaman Herrera, músico patagónico radicado en La Plata que había pasado por las filas de Laptra, otro sello musical platense. Refiriéndose a los planes que discutían sus nuevos amigos, JP dijo: "Al menos lo que yo entendí, esto es muy parecido a lo que plantea Shaman y otros con eso de Ciberbia, justo hoy lo estaba leyendo". Nicolás le contestó: "Dicen que es lo mismo... yo hablé con Rodrigo [por entonces, el manager de Shaman] pero no es lo mismo, porque es una red cerrada para ellos... qué sé yo, no digo que esté mal". Luego nos explicó que Rodrigo era el manager de Shaman y "bookea" 86 a la banda platense Sr. Tomate -en la cual también toca Shaman-, a la banda capitalina Guerra de Almohadas y al reconocido músico y productor Daniel Melero. En una entrevista publicada en el Suplemento Joven del Diario El Día el día anterior a la reunión del hostel, Shaman explicaba los objetivos de la red: "estamos intentando coordinar con las bandas amigas de todos los puntos del país una primigenia red para que los involucrados puedan viajar por los diferentes rincones del mapa" ${ }^{87}$.

Entre las redes de estos productores y músicos las relaciones con los funcionarios estatales se habían vuelto comunes. Mi trabajo de campo en Concepto Cero es contemporáneo al creciente interés que distintos organismos y agentes del Estado argentino comenzaron a prestar a estos músicos y a sus proyectos, interés que se inscribe en un movimiento global de expansión de las industrias culturales y de valorización de la cultura como recursos por parte del Estado (Yúdice 2002). Este interés jerarquiza el lugar de la "creatividad" en la economía capitalista contemporánea (Appadurai 2001, Menger 2002), especialmente entre los jóvenes (García Canclini 2011, Mc Robbie 2012), a la vez que

consiguiendo un "descuento de artista". Vemos así que la gestión propia del problema no era contradictoria con el involucramiento en programas estatales.

${ }^{86}$ Derivado de la palabra booking. En el capítulo V refiero al uso de este vocabulario profesional y empresarial por parte de miembros del sello.

${ }^{87}$ El músico y su manager proponían circuitos como Comodoro Rivadavia/Rada Tilly/Caleta Olivia/Pico Truncado, o La Plata/Temperley/Capital Federal, a la vez que compartían la idea de sumar disciplinas poesía, fotografía, cine, diseños- y obtener apoyos como la declaración de "Interés cultural y turístico" que ambos habían gestionado en el ámbito municipal. En: Impulsos aleatorios, Diario El Día, 6 de abril de 2012. Recuperado de: http://pasado.eldia.com/edis/20120406/impulsos-aleatorios-joven15.htm 
amplía el rango de acción de la política pública a mundos que no se consideraban parte de ella, en el marco de un desplazamiento del sentido de la expresión cultura desde las "bellas artes" a una noción antropológica (Writgh 1998). En nuestro país, alrededor del año 2000 comienza la implementación sistemática de políticas públicas específicas para diferentes expresiones artísticas y "creativas" - diseño, cine, música, teatro, entre otras- en los distintos niveles de gobierno, junto al establecimiento de instituciones oficiales dedicadas en forma plena a su estudio (Bayardo 2005, Miguel 2012), pudiendo caracterizarse el período como un momento de aluvión de políticas culturales.

A grandes rasgos, es en este contexto que cabría inscribir a proyectos como MICA (Mercado de Industrias Culturales Argentinas), BAFIM (Buenos Aires Feria Internacional de Música) o FIFBA (Festival Internacional de Folklore de Buenos Aires). Esto no significa que las políticas hacia el sector musical hayan sido en el período en estudio suficientes ni mucho menos sistemáticas pero sí novedosas para el área: Mihal y Quiña (2015: 150) señalan que durante los últimos años una serie de organizaciones de músicos han exigido apoyo estatal de diversos tipos -normativo y legal, financiero, etc.-, por lo que el Estado ha comenzado a dirigir recursos, aunque en pequeña cuantía si se los compara con los que reciben históricamente otras disciplinas como el teatro o el cine. No obstante, insisten en que música independiente se vale bastante más de la actividad privada que la estatal (2015: 151).

Por otra parte, la bibliografía señala que para el mismo período -y especialmente luego de la crisis de diciembre de 2001- se produce un movimiento, visible pero de difícil ponderación, de los músicos y la música autodenominados "independientes" hacia el espacio público (Lamacchia 2012, Quiña 2012) que explicaría en parte su crecimiento. Entre las manifestaciones más notorias de este vínculo se hallan la promulgación en el año 2012 de la "Ley de la música" (Lamacchia 2012) y el lugar protagónico, en comparación a todas las demás artes, que la música ocupó en los festejos políticos masivos de la última década, especialmente en la celebración del Bicentenario (Pujol 2013: 229). Estas relaciones entre los músicos y el Estado resultaban novedosas para mis interlocutores: las referencias a lo estatal aparecen en la tradición del rock como una inhibición o referente negativo (Vila 1985, Pujol 2007) mientras su institucionalización se realizaba de forma predominante a partir de ámbitos privados, especialmente las grandes compañías 
discográficas (Alabarces et al. 2008, Díaz 2005, Pujol 2013). En nuestro caso, estas relaciones no dependían directamente de la inscripción partidaria o ideológica, sino del encuentro en una manera de "entender la cultura". Durante el período, Concepto Cero se relacionó con distintas dependencias, programas y funcionarios del Estado en los niveles municipal $^{88}$, provincial y nacional. Todas ellos respondían en última instancia al Frente Para la Victoria, quien gobernó entre 2011 y 2015 la ciudad de La Plata, la provincia de Buenos Aires y el país. No obstante, las relaciones con grupos de funcionarios de distintas dependencias eran valoradas de forma muy diferente y lo satisfactorias que fueran no dependía en primera instancia de la inscripción política partidaria, como se verá a lo largo de este capítulo.

Durante varios meses del año 2011, en las reuniones para llevar adelante "Los Ellos", los integrantes de Concepto Cero siempre hablaban mal de un grupo de funcionarios que los hacían ir y venir por no mucho más que equipos de sonido. Tadeo exponía cómo para él operaba el grupo, a cargo de una dirección específica: “Agarran las cosas que ya ven más o menos que están armadas, que caminan y les ponen guita encima...", como contraparte exigen que el artista "ponga el logo" como si la dirección hubiera estado presente en todo el proceso de producción. Tadeo entonces remataba: "Pará, vos no hiciste nada". Nicolás decía que "no tienen idea de la cultura", y que uno de ellos era un "patotero" y un "puntero". La calificación de "puntero" no cuestionaba en sí el intercambio interesado de ambas partes, sino que este se redujera a la simple fórmula de "sonido por logo" sin que la otra parte "entendiera" la música ni que se preocupara por las necesidades y los proyectos del sector. En sintonía con esta mala experiencia y su valoración, los organizadores de Ciudad Alterna contaban a los de Concepto Cero sus conflictos con los mismos funcionarios. Esta dirección había promocionado su encuentro de rock como si fuera la organizadora y ellos habían tenido problemas con los auspiciantes. Al escuchar esta historia, Nicolás ironizaba con que estos funcionarios eran los que más necesitaban los cursos de capacitación que el grupo podía llegar a organizar y afirmaba "los malos manejos" y falta de comprensión de la actualidad de la escena.

${ }^{88}$ Para la mayoría, la relación con el Municipio tenía origen en invitaciones a tocar para eventos de la Municipalidad y por las políticas públicas a cargo de la Dirección de Juventud, en particular el evento anual Arte Joven que seleccionaba cada año nuevos exponentes en la música, la literatura, las artes visuales y otras disciplinas para ser expuestos durante una semana. 
Al conformar una red de bandas también proyectaban hablar en mejores condiciones con Nicolás Wainszelbaum, el interlocutor que tenían a nivel provincial. Este funcionario les había prometido reuniones de trabajo junto a él y Jorge Telerman, el director del Instituto Cultural, para avanzar en una agenda que tuviera como protagonistas a las bandas de la ciudad y de la provincia, más allá de proyectos puntuales como Catálogo Rock ${ }^{89}$ y otros lanzados por el Instituto. De acuerdo a Nicolás, este funcionario era "bastante complicado de ubicar" pero a la vez "accesible, en el sentido que es una persona con la que vos hablas y no hablas con un loco de traje del otro lado". En este mundo musical hablar del "traje" de las personas implicaba referir a su desconocimiento de la música. Al respecto de las culturas musicales de las multinacionales, Negus (2005: 140) afirma: "Existe la creencia, extendida sobre todo entre el personal de A y R [Artistas y Repertorio], de que la gente "creativa" viste de modo informal y de que llevar un traje es un signo seguro de que alguien no comprende la música”.

La idea de red era clave e implicaba al Estado como un actor más. Irisarri (2015) muestra para el caso de Fora do Eixo modos en que este colectivo se vincula a distintos actores políticos y hace política, anclado en alianzas pragmáticas y provisorias. Como veremos, TICA y las redes asociadas a Recalculando La Plata compartirán este modo de relacionamiento político que la autora citada denomina "pragmatismo estratégico". En el caso que analizo en esta tesis, además de estar inspirada en el conocimiento específico de los desarrollos de Fora do Eixo, la idea de red se retomaba de profusas literaturas que mis interlocutores seguían durante el período. Circulaba en particular un libro titulado Música para Camaleones, editado durante el año 2012 por Trànsit Projectes, el emprendimiento español que había financiado parte de la edición de "Los Ellos". Producido de forma colectiva, este texto se propone como un muestrario de referencias en "buenas prácticas" de trabajo en producción cultural y, específicamente en la música, desde el concepto clave de trabajo en red. La noción de red y el diagnóstico de una época de profundos cambios donde la cultura asume un lugar preponderante se teje a partir de citas de sociólogos, filósofos y

${ }^{89}$ El denominado Catálogo de Música de la Provincia de Buenos Aires -en vigencia desde el año 2009- busca catalogar artistas, bandas y sellos para convocarlos a presentaciones en vivo, participación en discos compilados - por ejemplo, las diferentes ediciones de Catálogo Rock-, festivales -especialmente el Festival del Bosque (antes FIFBA), realizado anualmente por la gestión provincial en la ciudad de La Plata- y rondas de negocios del denominado Mercado de la Música, donde se brinda la posibilidad de tener reuniones cara a cara con programadores de festivales y sellos discográficos internacionales. 
ensayistas como Manuel Castells, Gilles Deleuze y George Yúdice. Es verdad que, contemplados desde criterios académicos, estos autores han realizado planteos de distinta generalidad, alcance y reconocimiento, pero en el texto unos resultaban tan operativos como otros.

En particular, a partir de la presentación de 29 proyectos que marcan pautas y formas de trabajo para los lectores "emprendedores" en cultura, Música para Camaleones quiere demostrar que la novedad en el arte y la música actual radica en el "cómo", es decir, en la metodología de trabajo. Desde esta perspectiva, la singularidad de la música no está en la obra por sí misma sino en la forma de producirla. Es esta forma la que hace "destacar la belleza de una piel en apariencia tan poco singular que se parece a todas las otras pieles" (Trànsit Projectes 2012: 18). En el libro, la idea de red se conecta explícitamente con otras: trabajo interconectado, horizontalidad, proyecto, estrategia, sostenibilidad, creatividad. A lo largo del trabajo etnográfico pude notar cómo estas palabras se volvían parte de los discursos de algunos miembros de TICA: buscar que los proyectos sean sostenibles, promover el trabajo en red, tener una estrategia conjunta para hablar con el Estado, ser creativos para economizar recursos, etc.

Al respecto del predominio del concepto de red en estas prácticas culturales, Mc Robbie $(2002,2007)$ plantea para el caso de los jóvenes productores culturales de Reino Unido, y especialmente para su ciudad capital Londres, un proceso en el que las posibilidades de asociación y de colectividad son reemplazadas por una sociabilidad en red. De acuerdo a su lectura, asistimos a la emergencia de una economía cultural de bajos salarios y trabajo intensivo, compuesta por una vasta red de "personas creativas" que trabajan por cuenta propia y de forma autónoma (Mc Robbie 2002). Así, el énfasis en las redes se corresponde con un modelo económico y social más "neoliberalizado", donde cada persona “empleará mucho de su tiempo 'tejiendo redes', manteniendo las puertas abiertas para que cuando un proyecto se acabe pueda empezar otro" (Mc Robbie 2007: s/n). El resultado es trabajo creativo precario y el Estado mismo normaliza dicha precariedad, al volver irrelevantes las relaciones sociales formales de la vida laboral. A raíz de este análisis, podemos interrogar a nuestro caso con dos preguntas: por un lado, si la movilización de las redes obedece sólo a una necesidad de empleo o auto-empleo; por otro 
lado, más allá de la creación y sostenimiento de empleos precarios, cuál es el papel efectivo del Estado en el tramado de estas redes.

Lo que podemos adelantar es que la ampliación de la red implicaba para estos músicos tener nuevos "amigos", en el sentido ya definido: un lazo entre pares, personal pero no necesariamente íntimo, que se vuelve una "cooperación interesada" con el objetivo último de "vivir de la música". También nuevos "aliados", como podían ser ciertos funcionarios estatales -la mayoría de los cuales, más allá de su cercanía generacional, su estilo poco protocolar e incluso en algunos casos su trayecto en la escena, no se consideraban plenamente pares. En este sentido, en una conversación a principios del 2012 luego de las pérdidas monetarias de la presentación de "Los Ellos" en Niceto, Nicolás me había dicho: “...si yo consigo que Concepto Cero sea sustentable, que yo sé que por mes las cosas que salen entran y que eso te puede durar y que mínimamente puede tener un crecimiento... pero mínimo económico, pero no para quedarme para mí, sino para reinvertir y para poder ir agrandando, ya está. El tema es que eso no pasa y que no va a pasar hasta que nosotros tengamos muchas más conexiones". De distintas maneras, los dos casos de conformación de redes de amigos y de aliados, respectivamente TICA Red y la participación de TICA en el programa estatal Recalculando, tuvieron efectos en la buscada ampliación de las conexiones.

\section{Los comienzos de TICA Red}

Como fue señalado en el anterior apartado, TICA comenzó a constituirse en La Plata como una red a partir de las iniciativas de un grupo reducido de músicos y productores que fue interpelando a otros con los que venían relacionándose en fechas y eventos puntuales, además de que transitaban una misma "escena". A los músicos y productores culturales antes mencionados se sumaron los sellos Dice Discos, con centro de operaciones en City Bell/Villa Elisa; Tomas del Mar Muerto ${ }^{90}$, de La Plata; y Serial

\footnotetext{
90 Tomas del Mar muerto era un sello de La Plata que se definía a la vez como "sello", productora y "agrupación de amigos". Iniciado en el año 2010 editó a bandas como Fuego Amigo Camina Conmigo y Güacho, que tenían integrantes en común.
} 
Música $^{91}$, un sello interesado en las bandas de pequeñas ciudades bonaerenses, comandado por el que había sido socio de mi profesor de guitarra mencionado en el capítulo I. En el camino se sumó Desde el Mar, un sello de Mar del Plata, y Discos de Piedra, de la ciudad de Tandil. Lautaro y Nicolás entraron en contacto con otros sellos para incluirlos en la red, ninguno de los cuales terminó por participar plenamente: Laptra, quizás uno de los más famosos sellos de La Plata, y Pistilo Records, otro sello marplatense.

Entre los músicos que empezaban a conformar TICA se compartía la concepción del músico que asume la gestión de su propia obra señalada anteriormente. En esta línea, cobran sentido las palabras dirigidas de un músico a otro, durante una reunión y en un intento de convencerlo de que era importante que gestionara lo que hacía: "Si vos querés tener control sobre tu música vas a tener que hacerlo vos". Asimismo, se compartían referencias en el plano de la gestión musical y cultural. Por ejemplo, para los músicos de Güacho -del sello Tomas del Mar Muerto- la experiencia de Fora do Eixo también funcionaba como un norte. De manera quizás más radical, se entusiasmaban al relatar al resto el modo de trabajo de una de las bandas más famosas enredadas en FdE, Macaco Bong $^{92}$, cuyos líderes proclamaban ser "obreros del arte". En este sentido, los músicos de Güacho se enorgullecían de haber producido de forma artesanal su primer disco y en general, como decía su cantante, de "hacerlo todo".

Durante el período de mayor actividad de TICA, entre agosto de 2012 y septiembre de 2013, los músicos trabajaron juntos en la web, en el mantenimiento de plataformas virtuales - Twitter, Facebook y Tumblr- con distintas utilidades, como la agenda de eventos y los lanzamientos de discos de todos los sellos de la red, a la vez que la promoción mutua. Asimismo, se embarcaron en un sistema de invitaciones recíprocas para tocar, un modus operandi donde la banda receptora se encargaba del alojamiento de la invitada que sólo tenía que conseguir el transporte. Un ejemplo: el "punto TICA Mar del Plata" fue invitado a tocar a La Plata, y como contrapartida una banda de La Plata hizo lo propio en la ciudad balnearia. Fue el caso del ciclo Noches Navegantes, organizado por el sello marplatense Desde el Mar, evento al que fueron invitados Excursiones Polares de Concepto Cero y Un

\footnotetext{
${ }^{91}$ Serial Música era un sello fundado en el año 2005 que editaba bandas y solistas de la provincia de Buenos Aires.

${ }_{92}$ El primer disco de Macaco Bong se llamó "Artista Igual Pedreiro" ("El artista es igual al obrero"), expresión que se tornó un slogan de FdE (Irisarri 2015: 56).
} 
Planeta de Dice Discos. A partir de este arreglo, las bandas Alfonsina, Simmur y Luz París, catalogadas en Desde el Mar, fueron a tocar a La Plata. Los músicos aprovechaban estos viajes para llevar discos físicos propios y de los amigos a la ciudad receptora. Estos materiales quedaban en consignación del sello local, que luego se encargaba de la distribución y venta en sus eventos. Pero sin duda la actividad que les dio mayor convocatoria, visibilidad y prensa fue el Festival La Nueva Energía, al cual referiré más adelante.

Visto retrospectivamente, la conformación de TICA recibió impulso del deseo de reunión, formación y gestión colectiva por parte de distintos sellos y colectivos culturales, pero realizó un camino que fue habilitado en gran parte por distintos agentes estatales. Replantear la relación con el Estado era señalado como uno los objetivos de TICA por dos de sus voceros, Juan y Nicolás. En una entrevista a La Pulseada -realizada por una comunicadora que participó de los eventos de TICA, así como también de RecalculandoJuan decía: "Consideramos que el Estado es un actor más con el que Tica puede trabajar" En efecto, TICA se vinculó con el Instituto Cultural de la Provincia, con Recalculando y con el Municipio.

En particular, el primer evento que convocó a los sellos y colectivos que conformarían TICA y que funcionó muchas veces como plataforma para el sistema de recitales cruzados mencionado anteriormente fue Sonido Expansivo, un ciclo mensual de recitales acústicos que primero se llamó Acústicos en el Senado ${ }^{94}$. Inaugurado en mayo de 2012, se propuso como un "ciclo de rock acústico y arte en el Anexo del Senado Provincial" ${ }^{95}$. La ubicación del Anexo del Senado de la provincia en la intersección de las calles 7 y 49, una esquina neurálgica del centro de La Plata, era tomada por los organizadores como una promesa de ampliación de público, sumada a su carácter gratuito y al horario de las 19 hs. Cada uno de estos eventos ponía en escena a dos artistas en representación de dos sellos diferentes, con la condición de tocar sin mucha amplificación debido a las características de un espacio muy grande y no preparado acústicamente para

93 Celle, Juliana (2013). 23 abril de 2013. Con el sello de la autogestión. Recuperado de: http://www.lapulseada.com.ar/site/?p=4996 (consultado: 30/04/2013).

${ }^{94} \mathrm{El}$ nombre fue cambiado a la siguiente edición para evitar posibles problemas de copyrigth con un festival de Colombia.

${ }^{95}$ Significativamente, luego pasó a referirse como "música y arte emergente". Sobre este descentramiento del concepto de rock hablaré en el capítulo V. 
que toquen bandas de rock. Siempre se invitaba a un Dj distinto para "musicalizar" el espacio entre las bandas y un Vj para hacer las "visuales" cuando estas tocaban. También había muestras de fotografía. En las primeras ediciones, se realizaron talleres con el objetivo declarado de "brindar herramientas útiles a los participantes". No casualmente el primer disertante de estos encuentros fue Martín Mena, convocado para contar de qué se trataba el programa Recalculando a un grupo de músicos, participantes de sellos musicales, fotógrafos y productores culturales.

La propuesta para realizar eventos dedicados a un segmento de música juvenil en el Anexo del Senado provincial había llegado desde el mundo de la política provincial. Un senador amigo de un familiar de Nicolás proyectaba aprovechar el espacio de 7 y 49 para realizar eventos culturales y se le había ocurrido convocarlo, tal como me contaba Nicolás. El ciclo se sumaba a otros de folclore y tango, entre otras actividades culturales que se presentaban allí y que, políticamente, se tramitaban a partir de un sector político alineado con vicegobernador Gabriel Mariotto ${ }^{96}$. Inmediatamente, Nicolás y Cristóbal aprovecharon este espacio y los recursos monetarios que la Dirección les otorgaba por cada evento realizado para conectar con las bandas y sellos que les interesaban. Desde la mirada de Concepto Cero lo que animaba estas presentaciones acústicas era generar un espacio de trabajo colaborativo para la red en formación y pagarle por su trabajo a todos los implicados. Que se pagara era resaltado por ellos y también era un ítem que los músicos consideraban a la hora de tocar, además de las características del espacio, alabado en vivo por ellos en cantidad de recitales del ciclo. No es casual que en los primeros encuentros de Sonido Expansivo hayan tocado bandas de distintos sellos de La Plata y otros grandes conglomerados urbanos que serían claves en la conformación de TICA, como Dice Discos -con la presentación de Un Planeta- y Uf Caruf - con el show de Miro y su Fabulosa Orquesta de Juguete-, y el marplatense Desde el Mar -con las performances de Alfonsina y Simmur. Si bien la red no estaba compuesta solamente por sellos musicales, varios de los músicos integrantes repetían que era una "red de sellos", dando cuenta de la centralidad que aquellos tenían en su conformación y en la escena independiente.

\footnotetext{
${ }^{96}$ Como se verá más adelante no escapaba a los organizadores, al menos a Cristóbal y Nicolás, que durante el período 2011-2015 Mariotto fuera vicegobernador en una fórmula del Frente para la Victoria con Daniel Scioli y se enfrentara con él en posturas y acciones políticas.
} 
Las primeras ediciones de Sonido Expansivo fueron anunciadas en las redes sociales desde TICA Red, para la cual habían diseñado un logo. En estas primeras presentaciones se colocaron banners de TICA -en la puerta del Senado y en lugares centrales del espacio-, al tiempo que las visuales reproducían dicho logo en tiempos de descanso entre bandas. Sin embargo, el grupo organizador no se visibilizó demasiado y era difícil saber quiénes componían TICA si no se estaba de alguna manera implicado en el circuito de los amigos. De este episodio, escribí en mi diario etnográfico:

“Ángel subió al escenario, tomó el micrófono y nos dio la bienvenida a todos. Dijo que este era el primer recital de un ciclo de acústicos en el Senado, que se trataba de una nueva experiencia organizada por un grupo de gente vinculada a la música, a la cultura y a la gestión cultural”.

Ya me lo había dicho uno de los miembros del sello unos meses antes cuando me adelantó la posibilidad de estos recitales: “...el tema es que yo no quiero salir abrazado a Mariotto en ningún lado (...) pero quizás me la tengo que fumar digamos... hay que ver ahí hasta qué costo... pero bueno, el costo lo pago yo, no quiero que lo pague el sello". La precaución de "no quedar pegado" y "no quemar nombres" se percibía en esta visibilización débil e incluso en el hecho de que Ángel, un músico de Concepto Cero que no vivía en La Plata, hubiera hecho la primera presentación del ciclo frente al público. Entre el público, en los controles, y especialmente atrás de las sillas dispuestas para sentarse, una podía encontrarse a la mayoría de los miembros de TICA Red observándolo todo. Esta inquietud de "quedar pegados" se comprenderá mejor al relatar un encadenamiento de conversaciones provocada por una torpeza mía en el campo, tal como sigue a continuación:

En el primer encuentro del ciclo, el 19 de mayo de 2012, animaron el escenario Shaman y los Hombres en Llamas, y Miro y su Fabulosa Orquesta de Juguete. Como era mi costumbre, empecé a observar la convocatoria del evento: adelante mío, tres señoras bien arregladas, de más de sesenta años, una al lado de la otra y en primera fila; grupitos de jóvenes con termos de mate, que no tomaron allí (¿venían de otro lado?); Ángel, quien andaba de un lado para otro caminando; fotógrafos, músicos, algunos habitués de la escena; Nicolás con su I-pad visiblemente nervioso; varias parejas de veintitantos largos y de 
treinta con hijos menores de cinco años que descubrieron que el piso del lugar es excelente para patinar; adolescentes en edad escolar que tomaron videos del recital de Miro con Blackberrys. Comencé a extrañarme por la heterogeneidad del público y su componente etario, que no identificaba con los shows de Concepto Cero ni de la escena. Mi confusión aumentó cuando también comenzaron a llegar parejas muy ataviadas, cercanas a los cincuenta años, personas que, nuevamente desde lo que indicaba mi experiencia, no eran frecuentadoras de la escena independiente de La Plata ni de estas bandas.

Más tarde en un boliche cercano tocó Mostruo, banda que estaba trabajando con Nicolás. Varios miembros del sello y del grupo de TICA que estaba organizando el ciclo se encontraban allí. Cuando me los encontré en el recinto me preguntaron qué me había parecido el evento anterior. Después de darles mi elogiosa opinión personal, les pregunté: “Qué convocatoria rara la de hoy, ¿qué onda?”. Como parecieron no entender, fui al punto que me interesaba: “¿Vino gente a apoyar desde la política?”. Uno de ellos contestó: "No...sería un bajón si hubiera sido así" y me percaté de mi torpeza. Repliqué: “Ah, parecía eso en algún momento, había gente muy rara...”. Me respondieron que dado el lugar central que tiene el Senado en la ciudad muchísima gente que pasaba había entrado. Uno de ellos ejemplificó: “Unas señoras grandes, preguntaron en la puerta qué era y entraron". Yo dije que las había visto y concilié: "Sí, puede ser...sábado a la tardecita, hay mucha gente en el centro y llamaba la atención, además había un banner afuera". Pero mi interpretación no se originaba en la pura observación o en la perspicacia de una estudiante de ciencias sociales: el propio Nicolás me había marcado varias veces las vinculaciones políticas por las que había llegado a hacer Sonido Expansivo, por lo que yo entendía que la mayoría de los implicados no desconocían la centralidad de la apuesta y su vínculo con la política local. Para mí no era reprobable que personas del mundo de la política fueran a “apoyar" pero había olvidado que ellos temían "quedar pegados". Y una manera de que eso pasara era que la convocatoria de público se despegara de la escena de forma evidente.

Un mes después, en una fecha en el Pasaje Dardo Rocha, me encontraba cuidando la puerta con Leandro - un músico de TICA-y me dijo, riéndose: "Estuvimos en un acto de Mariotto". Me empecé a reír porque él se reía, al tiempo que continuaba su relato con distancia irónica: "Sí, andábamos por ahí y bueno...". Siguiendo esta línea, acoté: "Pasábamos por ahí y nos quedamos a escuchar". Luego agregó que "firmamos un contrato 
con ellos" y que en ese marco habían ido al acto, que era una conferencia de Felipe Pigna, porque les habían dicho que "faltaba gente". Seguimos hablando de este nuevo vínculo y me dijo que "los tipos se portaban de diez con ellos", confirmándome que recibían una suma adecuada de dinero para hacer el evento y que "nunca nos dieron nada [refiriendo al Estado, el poder, los políticos, de modo amplio], ¿una vez que nos dan algo nos vamos a negar?". En definitiva "a los tipos les sirve porque pueden decir que trabajaron en esos temas y a nosotros también nos sirve para hacer cosas".

En un momento de la conversación me di cuenta de Leandro que no buscaba sólo relatarme lo acontecido sino en parte ser aprobado en su accionar, ya que a algunos de sus amigos no les parecía del todo bien esta relación con el Estado. En efecto, tiempo después otro integrante de TICA me volvería a contar la historia, mientras tomábamos mate en su casa con Mariano, su compañero de banda, y aclararía sobre la asistencia al acto: "Nos habían pedido como que vayamos así, como que te piden, no es que te dicen 'tenés que ir'”, y continuó "pero si vos vas, ellos después van a tu evento, entendés...", frente a las caras de desaprobación de su compañero, que le replicaba "la política es lo más garca que vi en mi vida" y "le vendieron el alma al diablo".

Mariano no era el único en esta historia que sostenía los tradicionales principios anti-estatales del rock. En una reunión de Recalculando en La Plata, un productor de eventos comentó que con algunos de los presentes venían discutiendo si había que involucrarse con el Estado o permitir que este interviniera en la producción musical. Lo contó convencido de que se trataba de una discusión importante y sobre todo no saldada. Un joven que era parte del equipo de Recalculando enseguida replicó: “¿Eso discutieron? Pero eso es obvio...", con una expresión facial que daba a entender que desde su perspectiva allí no había una discusión; luego agregó: “el Estado somos todos”, frente a las caras no del todo convencidas de algunos músicos. Se revelaban así diferencias entre quienes se sentían más cómodos con una noción de la música no vinculada al Estado y quienes no veían esa relación como problemática. En este sentido, desconfianzas y sospechas acerca de posibles operaciones clientelares del Estado sobre la música no dejaban de ser formuladas. Sin embargo, al percibirse cierta apertura del Estado y una coincidencia en su concepción de lo musical, terminaba por prevalecer la disposición a tratar con sus agentes e instituciones. Infantino (2011) señala un desplazamiento similar 
para el caso de los jóvenes artistas de circo: cuando empezó su investigación en el año 1999 estos no visualizaban al Estado como un agente que pudiera incluir la promoción de sus prácticas artísticas. La continuidad del trabajo etnográfico "evidenció un cambio que habilita un campo de posibilidades diferencial en el que se puede evaluar al Estado como un agente que debe y puede garantizar derechos, incluso, derechos culturales”. (251)

\section{Una interlocución platense para el programa Recalculando}

Lamacchia podía plantear, en 2012, que "en la Argentina, hasta el momento, no existen políticas públicas con continuidad que tengan a la música en general y a la música independiente en particular en el centro de su interés" (155). Quizás Recalculando haya sido la primera en su tipo. En La Plata, el programa fue presentado por Martín Mena el último sábado de junio de 2012, durante la segunda edición de Sonido Expansivo. Si bien la convocatoria fue pública, Cristóbal, Juan, Nicolás, Juli, Lautaro y los organizadores de Ciudad Alterna la reforzaron con invitaciones a los miembros de los sellos Dice Discos, Tomas del Mar Muerto y Serial Música con quienes venían conversando, junto a fotógrafos y otros productores culturales. En la sala donde se realizaría la charla, alrededor de las sillas ubicadas en semicírculo para la ocasión, se encontraban unas quince personas. Martín se presentó desde su rol de programador de eventos en Tecnópolis y relató un par de fechas con "bandas grandes" allí realizadas, refiriendo como ejemplos a Kapanga, Bersuit y La mancha de Rolando. De acuerdo a su relato, en cierto momento les pareció que también sería deseable que "todos puedan ir a tocar a Tecnópolis", especialmente las bandas "independientes", que así podrían presentarse en un "escenario profesional”. Al programar a ciertas bandas independientes se habían percatado de que estas no manejaban una serie de conocimientos técnicos relativos a la ejecución musical en esa clase de escenarios. Así, Martín planteó que había reflexionado y concluido que en parte su tarea como responsable de una política pública era formar a dichos artistas: así presentaba el nacimiento del programa de profesionalización.

Narró asimismo algunas experiencias de sus viajes al interior del país para explicitar que el programa era federal. El objetivo declarado a mediano plazo era empezar a desarrollar circuitos culturales que no dependieran de la ciudad de Buenos Aires. Se 
inspiraba en parte en otras experiencias de trabajo en red y producción cultural, como la brasileña Fora do Eixo a la que ya he referido. En otra oportunidad, Martín dijo que esta organización "había materializado lo que nosotros queríamos hacer". La propuesta declarada tenía entre sus objetivos inmediatos amplificar la unión de fuerzas que ya de por sí se daba en los sellos y colectivos musicales. Pretendían lograr un ida y vuelta entre las propuestas de los músicos y el programa, materializada en distintas tutorías y "charlas técnicas" como también en pasajes y recursos que fueran necesarios y pudieran brindarse.

A principios de agosto de 2012 nos volveríamos a encontrar muchos de los presentes en aquella charla $-\mathrm{y}$ otros que se sumaron en las siguientes semanas- en la casa de un músico de uno de los sellos participantes, desde donde nos recogió una combi contratada por la Secretaría. Nos llevó a una ex fábrica textil, ubicada en el barrio porteño de San Telmo y recuperada como taller, espacio de encuentro y local de fiestas por un colectivo de artistas musicales y visuales, entre quienes se contaba la banda porteña Morbo y Mambo. Tal como relataba en mi diario etnográfico:

Alguno de los chicos tocó timbre y nos abrió Nicolás, que ya había llegado al lugar, no sé bien cuánto tiempo antes. Atravesamos un pasillo amplio pintado de blanco donde había varias cosas tiradas, básicamente mampostería, y llegamos a una sala que habían acondicionado para la ocasión. Había unas gradas de madera, de cuatro o cinco peldaños, y unas sillas también. El lugar donde iban a hablar las personas estaba como delimitado por dos banners, uno a cada lado. Los banners eran soportados por una estructura de plástico y rezaban "Recalculando. Desarrollo de circuitos culturales emergentes" y estaban en el tono del azul. En una mesita presumiblemente los organizadores habían puesto galletitas surtido Diversión en algunos platos, un termo con agua caliente, algunas botellas de Coca Cola de 2 litros y cuarto, sobrecitos La Virginia de café en saquitos y tés de la misma marca. Había azúcar también en un pote (creo). Debajo de la mesa se descubría enchufada una pava eléctrica (...). Empecé a recorrer el lugar porque vi que la sala donde estaba se vaciaba, “dónde están todos?”, me pregunté. Una puerta conducía a unas salas sin muebles y a medio pintar, donde había en un rincón unos tuppers muy grandes de plástico transparente con paquetes de galletitas Diversión y otras botellas de Coca Cola y de Sprite. Eran las provisiones de Recalculando. (...) Seguí recorriendo y me encontré con una sala grandísima donde había dos aparatos de metegol. Varios de los chicos los habían encontrado antes y ya estaban jugando. Esa sala tenía el techo muy alto y estaba desierta, no había más que los dos metegol. Frente a una abertura sin puerta, había otro espacio donde había colgadas pinturas de gran tamaño 
de algún artista. Había un chico trabajando. Había material de trabajo (acrílicos, pinceles), maderas cortadas y unas fotocopias sueltas (no anilladas) de un libro en inglés sobre arte.

Luego de este recorrido, le pregunté a Martín cuál era la relación del programa con ese espacio y él me contó que había conseguido el lugar a través de sus contactos en el mundo de la música. De acuerdo a su relato, "los pibes" no tuvieron problemas en prestarlo para el evento, aunque igualmente desde el programa "les tiramos unos mangos". Me planteó que el lugar era muy acorde a cómo él y su equipo -del cual se encontraban presentes dos estudiantes universitarios avanzados de comunicación de la UBA-pensaban que debía desarrollarse el encuentro. En este sentido, rescató que hubiera un metegol para jugar, lo que indicaba que no era un lugar acartonado o "formal", a los fines de mantener un tono relajado y de confianza entre los participantes. Esta preocupación me indicó la cercanía de tipo moral con la que el programa quería plantear su relación con los músicos, la cual contrastaría con el tipo de propuesta de otras políticas públicas.

Esta era la primera capacitación en Buenos Aires a la que asistíamos desde La Plata y se desplegó durante más de seis horas. La primera parte estuvo orientada a la explicación de la técnica del streaming ${ }^{97}$ por parte de Seba, socio de un emprendimiento dedicado a la transmisión de recitales en video online. La segunda, a la presentación de las personas y los colectivos presentes. En lo que restaba del año 2012 se sucederían otras cuatro jornadas de charlas y capacitaciones con este mismo formato, acompañadas de recitales en Tecnópolis dados por las bandas que viajaban para la ocasión. En esos encuentros nos encontraríamos con músicos, agentes de prensa y comunicadores, realizadores visuales y productores de otros pequeños sellos y colectivos musicales del país: Córdoba, Rosario, Formosa, Mar del Plata, Tucumán, Bariloche, serían de la partida. Estos encuentros de referentes de sellos de todo el país fueron aprovechados por Juan, quien inició y se responsabilizó de un proyecto llamado TICA TV que les realizaba breves entrevistas. Fue a partir de esta experiencia que también Juan se incorporó a trabajar dentro del equipo de Recalculando, orientado al área audiovisual del programa.

Para hacer honor a la perspectiva federal del programa y a la circulación que supone la idea de red, algunos participantes del mismo, de la zona metropolitana de Buenos Aires,

\footnotetext{
${ }^{97}$ Como explicó Seba en la capacitación, se refiere con streaming a la reproducción de un contenido sin descarga -es decir, sin dejar de usar Internet- como sucede en sitios musicales como Myspace o Bandcamp.
} 
eran invitados a viajar para participar de capacitaciones que se realizaron en otras provincias. La propuesta implicaba que cada colectivo, a partir de "referentes" que se planteaban móviles, también pudiera aportar un "saber" y volverse un "capacitador" de los otros. Así, Diego de Desde el Mar planteaba en una reunión que "cada uno tiene un área donde se manejaba mejor, por ejemplo Desde el Mar tiene muy claro cómo hacer festivales", a lo que un colega respondió: "Vos podés viajar a Bariloche a contar cómo se hacen festivales". Para el equipo de trabajo de Recalculando, la idea de red suponía una descentralización de la responsabilidad que se compartía por todos los miembros de la red. Martín Mena le decía a una productora cordobesa: "si una persona de un pueblo de Córdoba se conecta con Recalculando, yo te los voy a mandar a vos, les voy a decir que hablen con Cecilia, porque vos vas a ser la referente de Recalculando en Córdoba”.

A partir de la primera presentación en junio de 2012 se sucedieron meses intensos, nuevas amistades -en el sentido ya expuesto en esta tesis- se generaban entre los participantes y trascendían el programa en el que se habían reunido. Las capacitaciones y los viajes financiados por la Secretaría para asistir a capacitaciones en otras ciudades fueron aprovechados por estos músicos para realizar "fechas" por fuera del programa, lo que redundó en una ampliación de los contactos.

Estos lazos de amistad, además, se hallaban en el propio éxito de convocatoria del programa en La Plata. Es probable que esta dimensión vincular fuera volviéndose cada vez más clara para sus propios promotores, al punto que en la presentación oficial del programa en el MICA, realizado en Tecnópolis en abril de 2013, la subsecretaria de Cultura de Nación lo conceptualizara en parte como un "punto de encuentro" entre productores estéticos y un "nexo" entre los colectivos de música emergente e instituciones, entidades y empresas del ámbito público y privado. En este proceso, el programa se fue delineando como un "facilitador" y los promotores del programa, desde su inscripción en el Estado, se fueron planteando a sí mismos como "aliados" de estos músicos y de sus proyectos. La incidencia en las conversaciones de la palabra aliados era muy significativa: aliarse, ponerse de acuerdo para un fin común, implica una relación más puntual y restrictiva que la de los amigos. En este vínculo los aliados ofrecían una cooperación técnica, especialmente 
bajo la forma de asesorías en gestión, e indirectamente económica ${ }^{98}$. Esta cooperación, si bien no supone la fuerte afinidad moral que implica la categoría de amistad en este campo, no por eso se resuelve en la frialdad de un aparato burocrático: apela a la reciprocidad basada en criterios comunes para "comprender la música".

La transpolación a una idea de alianza para todas las relaciones que Concepto Cero y TICA tenían con direcciones, programas y funcionarios estatales no resultaría precisa ni justa. La relación con Martín y con el resto de los promotores, dada su trayectoria y una educación sentimental en parte compartida con los músicos -consistente en una valoración del rock independiente, de las prácticas autogestivas, etc.-, podía ser planteada con convicción bajo la idea de un "aliado". Más aún cuando en agosto de 2012 Nicolás se sumó al equipo de Recalculando. No pasaba lo mismo en el caso de los funcionarios políticos de la Provincia con quienes las relaciones se planteaban con otra distancia incluso cuando eran buenas. No obstante, todos estos representantes estatales seguían y proponían concepciones parecidas del papel del Estado en relación con estos proyectos musicales.

En efecto, en la reunión que tuvimos a fines de agosto del año 2012 con el director del Instituto Cultural de la Provincia de Buenos Aires, Jorge Telerman, se planteó al Estado como un acompañante de la iniciativa de los músicos. Para esta reunión, realizada en las oficinas del Instituto, algunos los miembros más activos de TICA -especialmente Juan, junto a Nicolás y Lautaro- escribieron un documento unificado para presentar al director y a otros funcionarios del Instituto. Tal como había sido el objetivo al comienzo de esta historia, los músicos y productores de TICA pudieron dar cuenta de su "representatividad" y plantear desde esa posición cuáles eran sus problemas más importantes. A diferencia de otros sellos que participaron de la reunión, los de TICA se habían encontrado en relativa sintonía con los funcionarios. Cuando otro sello participante de la reunión planteó la posibilidad de que una persona del Instituto Cultural se encargara de hacer los trámites editoriales en SADAIC porque ellos como sellos independientes no tenían, la respuesta dio el tono de cuál debía ser el vínculo. Uno de los funcionarios le respondió: "Capaz habría que hacer una capacitación para que sea más simple el trámite" para luego aclarar que las intenciones de la política del Instituto eran "brindar herramientas que el sector se tiene que

\footnotetext{
${ }^{98}$ El programa no financiaba proyectos de manera directa, pero al hacerse cargo de viajes de músicos referentes terminaba por financiar sus proyectos, una vez que estos músicos activaban otras redes a partir de esos viajes.
} 
apropiar...ese laburo lo tienen que hacer ustedes". La idea del papel del Estado era en este caso muy similar a la de Recalculando: el de "facilitador". Es así que Telerman podía cerrar la reunión con la propuesta de brindar "atajos": "para llegar al mismo lugar, que el camino sea menos desgarrador".

Un trabajo reciente de Mihal y Quiña (2015) presenta el sentido que los productores tienen del papel del Estado en los mundos de la producción editorial y musical en la ciudad de Buenos Aires. De acuerdo a lo relevado, las intervenciones con recursos del Estado son apreciadas por los músicos y editores indagados -a la vez que a veces criticadas por insuficientes. Para ellos, el Estado aparece como un "garante financiero" tanto de la actividad y de su carácter independiente (Mihal y Quiña 2015: 149) ${ }^{99}$. El trabajo etnográfico que aquí presento da cuenta de que los recursos estatales son importantes en un sentido específico: en tanto fueran aprovechables para volver más sólidas escenas y propuestas musicales que ya tenían un recorrido antes de encontrarse con estos recursos. Tal como registré en una reunión de Recalculando, en La Plata a fines del año 2102, luego de una charla del pre MICA:

Nicolás, Ceci [productora de Córdoba] y Martín coincidieron en que cuando [una manager platense] había dicho [en la charla] que un festival había sido un éxito los dos años que lo hizo pero que luego no lo había podido hacer más porque se había caído la financiación del Estado, claramente no había sido un éxito, si ella (y los que la acompañaban) no había logrado sacar algo de ahí más a largo plazo. O incluso que el festival se siguiera haciendo sin el Estado. Entonces empezaron con que si un día Recalculando no existía más, todo lo que se generara tenía que seguir existiendo más allá de Recalculando. El planteo de Ceci era "si mañana Martín se enloquece, se va a otro país..." que terminó en un "mañana Martín se muere” y muchas risas por parte de todos...

Por otra parte, los recursos monetarios o materiales directos no eran lo único que en ese vínculo se jugaba. De hecho, y como se ampliará en el último apartado, la capacitación y la asesoría resultan conceptos claves para definir al programa Recalculando -pero también existe ese tono en las intervenciones del Instituto Cultural. En este marco, el

\footnotetext{
${ }^{99}$ Los autores distinguen que la industria editorial cuenta con una ventaja por sobre la música respecto de las líneas de financiamiento, subsidios y premios otorgados en materia literaria.
} 
Estado participaba de la promoción y legitimación de vínculos "profesionales" con la música donde el músico independiente es su propio promotor. Por lo demás, estas políticas culturales promueven cierto tipo de músicas en detrimento de otras. En este sentido, Luker (2010) afirma para el caso de BAFIM una situación en la que en nombre de la diversidad musical algunas propuestas populares son excluidas. Si se miraban las bandas editadas en los distintos discos de Catálogo Rock sucedía algo parecido: lo que se consideraba rock coincidía con los criterios de la escena emergente de La Plata y la zona metropolitana de Buenos Aires, en tanto no se incluían bandas que se identificaran con el llamado rock chabón $u$ otras vertientes del rock más plebeyas ${ }^{100}$.

\section{Una teoría de la situación}

En el anterior apartado afirmé que las capacitaciones funcionaban como un espacio de sociabilidad, donde se tejían vínculos y se ampliaban redes. No presté atención aún al hecho de que las capacitaciones adquieren positividad por sí mismas: en ellas efectivamente se aprende algo. ¿Qué es lo que se aprendía? A lo largo del trabajo etnográfico asistí con ellos a capacitaciones que tomaban como objeto saber hacer un streaming, gestionar las redes sociales de la manera más eficaz, saber armar una estrategia de prensa, conocer los diferentes tipos de licencias de propiedad intelectual, etc. Pude notar cómo muchos de los saberes expuestos en las capacitaciones luego eran aplicados a eventos posteriores. Así, luego de la capacitación brindada por Seba sobre la técnica del streaming, los chicos probaron "strimear" en el siguiente Sonido Expansivo. Cristo fue el encargado de hacerlo con una nueva cámara que se había comprado. Lo vi manipulándola en su trípode sobre unas cajas de cartón marrón que encontraron porque "estaba muy baja". Al año siguiente Cristo ya le daba indicaciones a Diego de Desde el Mar cuando este tenía que hacer para TICA un streaming desde Mar del Plata. Otra serie de episodios de campo me mostró la necesidad, en escenarios "profesionales", de que la banda provea a los organizadores del

\footnotetext{
${ }^{100}$ Fueron editados por Catálogo Rock la mayoría de los artistas que aparecen mencionados en esta tesis: Sr. Tomate, Excursiones Polares, Un Planeta, Güacho, Miro y su Fabulosa Orquesta de Juguete, Shaman y los Hombres en Llamas, Él Mató a un Policía Motorizado, Casimiro Roble, Mostruo, Brahmán Cero, entre otros.
} 
evento de una planta de escenario ${ }^{101}$, concepto que resultaba completamente desconocido para mí pero también para algunos de los músicos. Gráficos de planta de escenario comenzaron a ser incorporados por Concepto Cero para las actuaciones de las bandas en Tecnópolis, por ejemplo.

Un análisis del intercambio de saberes y del aprendizaje técnico en estos espacios sería interesante, pero mi mirada en el campo no reparó tanto en esos procesos. Sí registré de qué manera la capacitación era un espacio donde comenzaban a volverse moralmente positivas un tipo de perspectivas para la práctica musical que en otros momentos -no sólo de la historia de la música juvenil, sino de las propias vidas de los músicos participanteshubieran resultado reprobables, "caretas" o simplemente inimaginables. Una de esas perspectivas era, claramente, la profesionalización. En el próximo capítulo analizaré con más detalle el proceso de profesionalización de Concepto Cero y en ese marco sus figuras subjetivas claves: el músico que se hace cargo de la gestión y en ese hacerse cargo produce un cambio en su modo de vincularse con la música y con los otros músicos. Pero durante el año 2012 en las capacitaciones ya pude observar indicios de esta situación entre los miembros de otros sellos. Los sellos ensayaban distintas formas de profesionalizarse a lo largo del proceso de mutuo aprendizaje que habilitó TICA Red. En el momento de mayor actividad de la red TICA, Lautaro de Uf Caruf nos mostraba un archivo con una propuesta para dividir su sello en distintos departamentos o áreas: prensa, diseño, eventos, distribución, artística, tesorería, legal, dirección, articulación. De la misma manera, Dice Discos establecía una persona para prensa: si bien era el primo de uno de los músicos, suponía una función específica que antes no tenían.

Además de formarse en distintos aspectos del mundo de la música y ensayar maneras de ser más profesionales, en las capacitaciones los músicos participantes encontraban y se apropiaban de una teoría de su situación, esto es una manera de comprender su autoproclamada novedad en el mundo de la música, que los más

\footnotetext{
${ }^{101}$ La noción de planta de escenario refiere a una representación - generalmente gráfica, en forma de dibujo o croquis- de los canales que usa la banda/artista para tocar, incluyendo los dispositivos técnicos que demanda en vivo, como la especificación de la cantidad y tipos de micrófonos y amplificadores, la cantidad y posiciones de tarimas y pies -de micrófono, de teclado-, etc. Esta representación también incluye la ubicación de cada integrante y sus instrumentos en el escenario. Este gráfico explica así al promotor y al personal técnico las necesidades del artista. Resulta entonces evidente que se desconociera o aunque se conociera no se usara: estas bandas suelen autogestionarse sus propios recitales, armar sus escenarios y manejar su propio sonido: no precisan de dicho esquema.
} 
involucrados comenzaron a relacionar con otros discursos y lecturas, incluido el mío propio en tanto "socióloga".

En mi trabajo etnográfico, la charla que da el periodista Eduardo Fábregat en Recalculando a fines del año 2012 abrevia una teoría de la situación donde la novedad es el resultado de una comparación de la situación actual con una imagen clásica del funcionamiento de la industria discográfica. En un tono encendido y convincente, a partir del caso de los Beatles a Fábregat le interesaba mostrar cómo "unos chicos que hacen música por gusto" se convierten en "esclavos de un sello discográfico", con obligaciones de sacar discos y realizar giras. Encontramos el problema de "vivir de la música", las políticas de los sellos discográficos, de los managers y de los intermediarios. Los Beatles funcionan como condensación del comportamiento de música e industria que se repite posteriormente en la historia. Pero "los Beatles no sirven para explicar lo que pasa hoy". Desde hace por lo menos diez años, calcula Fábregat, se diseminan una cantidad de sellos discográficos, productoras y músicos "por fuera del negocio", dada la facilidad que las nuevas tecnologías dan actualmente para prescindir de los intermediarios. Existe un desfasaje y un cambio en las relaciones de poder, en el marco del cual el modelo de negocio se vuelve cada vez más viable para los independientes, y sobre esto aclara: "no es que le vamos a ganar a Universal, pero es más viable el modelo que en años anteriores". Ante la "sordera de la industria", "la varita mágica se terminó": cada vez funciona menos que una banda "la pegue", es decir que llame la atención de las grandes compañías y sea producida por ellas. Por el contrario, "hoy una banda puede aprender a llevar el negocio en la escala que uno puede llevarla", y para continuar este argumento apela a "los músicos del interior" presentes en la sala; busca su complicidad y dice que antes era "una locura" desarrollar un grupo fuera de la ciudad de Buenos Aires.

Muchos de los músicos que lo escucharon conocían de antemano algunos de los lineamientos principales de este discurso - ciertos puntos, de hecho, circulan hace años entre ellos como críticas a "la industria"- pero encontrarlos en un relato coherente y articulado no era tan común en la escena, además de que esta crítica sea realizada por un actor legítimo como puede serlo un periodista de un medio de gran circulación. El efecto no puede ser subestimado. En una reunión de TICA, Lisandro de Güacho retomó a "un periodista de Página/12 que fue a Recalculando", y le preguntó a Nicolás -que estaba al 
lado suyo- cómo se llamaba para citarlo. Para Lisandro, Fábregat había hablado sobre el "nuevo paradigma del músico" correspondiente a una situación en la que el "viejo modelo ya no funciona", por lo que al músico se le exigen responsabilidades por aspectos de su práctica musical de la que antes se encargaban otros. Es así que volvió a su noción del "músico obrero" que toma a su cargo "desde el primer ladrillo hasta que la casa funcione". Lisandro se había apropiado de lo trabajado por Fábregat desde una noción de proletarización que el resto de los músicos probablemente no compartía. Este tipo de intervenciones instalaban la ambigüedad para un modelo de producción y gestión de la música que podía ser leído desde la posición de Lisandro pero también desde la de Nicolás o Ángel, en la que el músico más que proletarizarse tenía que convertirse en un experto en gestión, tal como presento en el próximo capítulo.

En Concepto Cero acompañaban estas capacitaciones con lecturas de publicaciones periodísticas y académicas y ensayos de conceptualización sobre la actualidad de los sellos, de la industria y de los músicos. La lectura de publicaciones periodísticas desde el interés puesto en la gestión estaba bastante generalizada. Por su parte, Damián posteaba regularmente información estadística sobre la industria musical, especialmente sobre soportes musicales y medios digitales, en el grupo privado de Facebook del sello. Con Ángel siempre tenía conversaciones sobre la sociología de la música en Argentina, a la cual conocía por ser graduado de comunicación y alumno de una maestría afín a las temáticas que yo estudiaba. A la persona que más pude observar en sus hábitos de lectura fue a Nicolás. En su biblioteca, primero en la habitación que tenía en casa de su madre y luego en su departamento, junto a los libros de arte visual y fotografía, se encontraban otros sobre management $\mathrm{y}$, en particular sobre el negocio de la música: "All you need to know about music business", de Donald Passman y "How music got free The End Of An Industry", de Stephen Witt. Pero también ensayos sobre temas musicales: “Cómo funciona la música”, de David Byrne y "Retromanía", de Simon Reynolds.

Los libros circulaban, especialmente los que proponían muestrarios de referencias en "buenas prácticas" de trabajo en producción cultural y, específicamente, en la música. Leídos para conocer experiencias de creación y gestión musical en otros países, en la búsqueda de ideas y referencia, encontramos las lecturas de Música para camaleones referidas al principio de este capítulo. Este texto circuló entre las redes de TICA y fue 
usado para al auto-diagnóstico de proyectos en Recalculando. A mediados del año 2013, Nicolás trajo de un viaje que realizó como capacitador de Recalculando a Colombia otro texto de esta clase: Manual para la creación de portafolios musicales, realizado por un grupo editorial llamado Poliedro y editado por el Ministerio de Cultura de ese país. Cuando me lo mostró estábamos merendando en una estación de servicio con El Tuca, un músico de La Patrulla Espacial, banda nunca catalogada en el sello pero con la que siempre se vinculaba. El libro, impreso en papel grueso y de calidad fotográfica, era una especie de manual para bandas y artistas. Mientras yo reparé en una serie de artículos sobre redes y plataformas digitales, gestión y un anexo con modelos de contratos, El Tuca también se mostraba interesado en el libro, lo ojeaba y comentaba con Nicolás los modelos de planta de escenario o riders que el libro proponía, en los cuales yo no había reparado.

$\mathrm{Al}$ interior de Concepto Cero un interés fundamental era conceptualizar la propia práctica musical: fui testigo y partícipe de varios intercambios acalorados sobre en qué sentido el sello era también otras cosas o cuál era su identidad. Cando Nicolás comenzó a formar parte del equipo de Recalculando, y especialmente cuando comenzaron a escribir artículos para la guía orientada a proyectos emergentes que editarían en el año 2015, en su casa empecé a encontrar libros de editoriales universitarias y académicas además de publicaciones del Ministerio de Cultura. En esta línea, las investigaciones coordinadas por García Canclini y Cruces (2012) sobre nuevas sociabilidades y patrones en la música y las artes, con las que dialogo en mi tesis, me fueron "linkeadas" primero por Nicolás antes que por cualquier comentarista académico. Para él estos textos eran importantes porque brindaban información y decía "los que estén a cargo del sello tienen que tener..., no la posta digamos, pero tener información en más temas...". Estos libros también ofrecían vocabulario adecuado para el diálogo con "los privados", como podían ser los "compradores" de una ronda de negocios en el MICA y con el Estado, léxico que a veces Nicolás sentía que no tenía.

En un mundo musical donde los discursos de las ciencias sociales tenían algo para decir, mi participación en las redes del sello no pudo más que ser modelada por esa promesa. Para introducir esta cuestión, transcribo un fragmento de mis notas de campo fechadas en agosto de 2012. Se trata de un momento de cristalización, donde se vuelve evidente la situación de uso y valorización de la figura de las ciencias sociales. El episodio 
transcurre en una ronda de presentaciones personales en una reunión en La Plata entre los miembros de Concepto Cero, promotores y participantes de otros sellos "amigos" de la ciudad y Martín como promotor de Recalculando:

Cuando terminó de hablar, Nicolás me miró y dijo "no sé Ornela si te querés presentar", algo que no hizo con ninguna otra persona. Era mi turno en la ronda y no me quedaba muy claro si me introducía sólo porque yo antes de entrar habría bromeado con él, Cristóbal y Ángel [otros miembros del sello] acerca de que me daba vergüenza la situación, o bien porque él me había invitado y debía suponer - correctamente- que yo no conocía al resto. Empecé a hablar retomando lo que había dicho Martín. Dije: "Yo soy Ornela y no soy ni música ni gestora cultural ni tengo un boliche ni nada....nada de eso" [haciendo alusión a las anteriores presentaciones de los demás] (y ahí me reí, y pude ver que Ángel y Nicolás también se reían). "Soy socióloga y estoy acá porque estoy haciendo un trabajo, una investigación. Justamente (y lo miré a Martín), todo lo que vos dijiste hace bastante eco con lo que yo trabajo, que es la profesionalización de la música independiente". Seguí, di un par de vueltas sobre la cuestión de lo profesional, enfaticé que era algo que me interesaba, y seguí retomando cosas que se habían dicho. Continué: "Hace como un año que vengo trabajando con Concepto Cero, siguiendo lo que ellos hacen...que esperemos que se plasme en una tesis de doctorado...". Luego miré a Juan [un chico de otro sello que había hablado antes] y a Martín y les dije "muy interesante todo lo que contaron" y agregué "bueno, nada, creo que nada más", y me seguía riendo un poco (es que me había puesto un poco nerviosa). Entonces, Nicolás dijo "bueno, es más de lo que hacemos todos nosotros" y Ángel dijo "una tesis de doctorado...". Martín, entonces, tomó la posta y mientras me sonreía y miraba fijamente dijo "es re importante tener sociólogos, a veces uno necesita armar un relato, una justificación, y piensa 'qué bueno sería tener un sociólogo ahora' porque ellos eso lo resuelven más fácil, uno en cambio se mata pensando", y mirándolo a Nicolás dijo "re groso tener un sociólogo con Concepto Cero...” y entonces Nicolás, aprovechando el momento para hablar, dijo para todos "yo me cuelgo del título universitario de ella". Todos se rieron y yo también, muerta de vergüenza.

Por mi parte, estaba estupefacta: no me sorprendía la aceptación que había logrado mi participación en las redes de Concepto Cero pero sí la legitimación que mi adscripción y orientación profesional encontraba en la organización. Es verdad que una parte de dicha legitimación podía venir de la diferenciación que les otorgaba "tener un sociólogo" en relación con otros sellos de La Plata. Sin embargo, había un motivo más profundo. Las 
ciencias sociales eran importantes para mis interlocutores porque desde su perspectiva podían construir un relato, una explicación, del cambio que ellos experimentaban. En los resultados de una investigación realizada a mediados de los años 90, Negus (2005: 32) ha observado que la cultura de producción de las multinacionales de la música, construida por los miembros de dichas compañías, extraía varias de sus ideas de los estudios culturales, la sociología, la musicología y la semiótica, generalmente en sus versiones mediadas por el periodismo, los cursos y los medios de comunicación. Se trata de una observación que el autor no profundiza pero de la lectura de su investigación se desprende que los directivos y trabajadores jerárquicos de las grandes compañías estaban más que nada interesados en sociologizar al público, a fin de otorgarle una pátina de certidumbre a un "negocio irracional" $" 102$. De manera diferente, mis interlocutores eran más propensos a realizar una versión del tan mentado autosocioanálisis bourdieano. Lo que les interesaba era conceptualizarse a sí mismos y sus proyectos en un momento de reconfiguración histórica del campo.

Con más énfasis a partir de este momento, Nicolás empezó a convocarme a otras actividades además de las fechas y reuniones del sello. Trabajamos juntos el armado de bloques de los elementos en los que un colectivo debía formarse, para empezar a pensar capacitaciones en torno a esos ejes y posibles candidatos a brindar cada capacitación. Además armé un relevamiento de instituciones dedicadas a la formación en gestión cultural, y empecé a participar más activamente en las discusiones conceptuales que tenían lugar en las reuniones, por ejemplo al respecto de la identidad del sello. Era usual que él o Ángel me dijeran “te necesitamos para conceptualizar...”. De esta manera, imaginaban para mí un papel activo en el proceso de institucionalización y de profesionalización del sello.

A tono con estos pedidos, cuando a mediados del año 2013 presenté mi tesis de maestría, les envié una copia y su lectura se extendió entre quienes no solían leer estos textos -que leyeron en general la Introducción-, mientras en los casos de Ángel y Nicolás la lectura fue completa. En un principio, las devoluciones se limitaban a lo "interesante" que les había resultado, mostrando cierto orgullo por haber sido protagonistas de un texto académico. Meses después, Nicolás me confirmó que habían leído la tesis en el grupo de

\footnotetext{
${ }^{102}$ Refiere a una concepción del negocio -afirmada en el estudio de Negus tanto por trabajadores como directivos- donde es necesario producir varios fracasos para encontrar un éxito, dado que no es posible predecir el gusto de los públicos.
} 
trabajo de Recalculando, inmerso en el armado de un libro orientado a músicos y colectivos

emergentes. Más adelante, Ángel me hizo una devolución muy informada, discutiendo conmigo nuevas preguntas que surgían de esa tesis y que decidí elaborar para mi tesis de doctorado.

\section{La desactivación de TICA Red}

Mientras se sucedían los recitales acústicos mensuales en el Senado y las capacitaciones de Recalculando, los miembros de TICA Red se encontraban también en las noches de la escena. Durante el período de máxima actividad produjeron fechas en común, entre ellas "El compromiso", donde Uf Caruf y Concepto Cero se "comprometieron" como pareja de sellos. Pero la red funcionaba a toda hora: en el grupo privado de Facebook de TICA se sucedían propuestas para realizar ferias de discos en eventos de otros sellos, se compartían flyers de fechas de cada sello para que los demás los amplificaran, se "linkeaban" los lanzamientos discográficos de los distintos artistas e información de políticas públicas. El grupo privado tuvo su pico de actividad entre los meses de enero y mayo de 2013 a raíz de la organización del festival La Nueva Energía. Además de fechas en común, el grupo activó otros proyectos: la realización de un catálogo de todos los discos de TICA para tareas de distribución, la realización de un ciclo de recitales en streaming de las distintas bandas para el canal de TICA, la presentación de un proyecto de desarrollo de producción digital para una convocatoria del Instituto Cultural, la realización de recitales y capacitaciones en pequeños pueblos de la provincia de Buenos Aires, etc.

Varios de estos proyectos no tuvieron continuidad y terminaron por difuminarse en el sinfín de actividades que la red se proponía: en la provincia se realizó sólo un Festival en Alem, motorizado principalmente por Santiago de Serial Música; el ciclo por streaming tuvo muy pocas sesiones, entre ellas la realizada por Desde el Mar desde Mar del Plata. Pinochet Cobos (2015) ha marcado a la inestabilidad como una característica acusada de las escenas y redes de creación estética entre jóvenes. En su investigación sobre las nuevas generaciones de artistas visuales mexicanos, plantea que estos participan de "un número amplio de iniciativas artísticas, las cuales por lo general no constituyen conformaciones estables en el tiempo, sino más bien proyectos efímeros que valoran el movimiento de la 
escena y la multiplicidad de sus propuestas" (Pinochet Cobos 2015: 74). Si bien esto era una característica también de la escena en la que TICA participaba, hacia el interior de ella se produjo también un "quiebre de profesionalización" -las palabras son de Nicolás- que cooperó al alejamiento.

Luego de varios meses de acercamiento mutuo en el que habían elaborado un diagnóstico sobre la necesidad de captar nuevos públicos y obtener mayor visibilidad, había surgido entre los participantes de TICA la idea de hacer algún evento en común que fuera además una presentación del colectivo en sociedad. En febrero de 2013 comenzamos a reunirnos en las casas de diferentes músicos con el objetivo de organizar un festival bastante grande en La Plata ${ }^{103}$. El festival, llamado finalmente "La Nueva Energía. Encuentro de sellos de música emergente", tuvo dos ediciones, una en mayo y otra en septiembre del año 2013, en la que participaron en total once sellos de la provincia ${ }^{104}$. En ambas ediciones, se invitaron a diseñadores de indumentaria amigos que vendieron prendas producidas de forma artesanal. También los organizadores habían armado una "feria de discos", donde se podían adquirir los materiales - discos, remeras, pins, dibujos y fanzinesde las bandas que tocarían esa tarde noche y de los sellos en general. La primera edición propuso una instancia de capacitación, específicamente para músicos pero abierta a la comunidad en general con la charla "Ideas para músicos: asociatividad y trabajo en equipo". El evento fue auspiciado por Recalculando y la Secretaría de Cultura de la Nación -a cargo de quien estaban los viáticos de los responsables de la capacitación-, Eventos Comunales de la Municipalidad de La Plata -quienes brindaron luces, gazebos y el espacio- y el bar Pura Vida. Ambos festivales tuvieron una convocatoria mayor a la de las bandas más exitosas por separado y obtuvieron una gran repercusión en la prensa local, así como en el mundo de la música emergente de La Plata y de la zona metropolitana.

Poco tiempo después del último evento, en octubre del año 2013, desde el grupo privado de Facebook de la red se propuso una reunión de balance y de planificación de nuevas actividades. Los chicos de Concepto Cero estuvieron muy insistentes en consumarla

\footnotetext{
${ }^{103}$ La organización se hizo especialmente a partir de "skypes" y "handouts" entre los distintos referentes de los sellos, de los cuales no participé y no tengo registro.

${ }^{104}$ Entre ambas ediciones participaron los sellos Fuego Amigo Discos (CABA), Mandarinas Records (LP), Serial Música (BA), Desde el Mar Discos (MDP), Uf Caruf! (LP), Concepto Cero (LP), Dice Discos (LP), Tomas del Mar Muerto (LP), Laptra (LP), Caminar de elefante (LP), Comunidad del fuego (LP), además del grupo audiovisual Parquee (LP) y bandas independientes de la escena no catalogadas en sellos.
} 
y propusieron varios horarios alternativos. Mientras en el grupo privado de Facebook en el que se había anunciado la reunión éramos veintisiete y en las reuniones habíamos llegado a ser casi veinte, ese día a las 6 de la tarde en el café del Pasaje Dardo Rocha sólo éramos cinco - de tres sellos platenses diferentes: Juan Artero, de Uf Caruf; Lucio, de Dice Discos; Cristóbal y Nicolás, de Concepto Cero. En esa reunión, los ánimos estaban caldeados y a razón de las ausencias las quejas se propagaron: "no puedo andar corriéndolos a todos", "las cosas no funcionan con tres flacos empujando a cincuenta", "lo que pasa es que son todos unos jipis que no trabajan", etc. Luego, hicieron un repaso de los ausentes y acordaron en quiénes, a pesar de no haber venido, estaban "en la misma", esto es, "veían a futuro" frente a los que "no la ven". Estos últimos, aparentemente, "se quieren quedar tocando para veinte tipos", lo que no estaba en los planes de los presentes. Este grupo no comprendía que los dos principales objetivos para los sellos emergentes, si es que quieren progresar y no quedarse en ser una especie de "vanguardia sin público", son el obtener recursos y profesionalizarse. De esta manera, se establecían diferencias dentro de la red de “amigos" ampliada que era TICA Red. En este camino, y como se verá en detalle en el capítulo cuatro, Concepto Cero se había empezado a diferenciar marcadamente de otros sellos de La Plata de los que tengo conocimiento, incluidos algunos de esta red ampliada.

Lucio puso sobre la mesa la que llamó "la gran cuestión": "generar recursos". Nicolás introdujo entonces sus contactos en Spotify, una plataforma online de venta de música, y Cristo propuso salir a "buscar privados". Nicolás contó que se estaba escribiendo con Spotify y que les había dicho que él estaba vinculado a otros sellos porque "no es lo mismo un boludo con ocho discos editados que si nos juntamos y tenemos noventa". Pero a la vez planteó: "Yo sé que si pongo esto en el grupo de TICA todos se copan pero nadie sabe ni puede hacer un contrato de cesión de derechos digitales". Spotify era quizás una oportunidad de obtener dinero, pero requería de mayor profesionalismo en algunas cuestiones. Por su parte, Cristo contó que unas semanas atrás en el festival Trimarchi había hecho un contacto con los representantes de un "un aperitivo que estaban tratando de posicionar", la marca Cynar. Él "había pegado buena onda" y "los tipos estaban re interesados en auspiciar" un festival del estilo de los que había hecho TICA. Lucio concluía que "el principal problema es la profesionalización de la escena" y todos acordaban. Se propuso otra reunión a comienzos del siguiente año, pero no hubo respuestas: la experiencia 
ya estaba desactivada. En enero del año 2014, Cristóbal y Nicolás me confirmaban: “TICA no existe más”.

Las preocupaciones de los músicos por la gestión, la sustentabilidad de sus proyectos musicales y la profesionalización habían madurado durante los años 2012 y 2013 al calor de esta experiencia. La relación con el Estado en sus diferentes niveles y el intercambio con otros colectivos en TICA Red les había enseñado a hacer las cosas de un modo más “prolijo” o quizás más “profesional”. En este proceso habían dado con una teoría de su situación y habían positivizado moralmente volverse "profesionales", estableciendo objetivos que como músicos "independientes" o "emergentes" deberían darse. Aproveché un silencio en la conversación de aquella tarde y se los dije. Cristo acordó conmigo, pero agregó rápidamente "no es así para todos, no se puede discutir esto con todos, no todos lo ven".

Al entusiasmo le había seguido el desencanto. Años después Ángel me dijo que “TICA no generó ninguna otra cosa que un festival. Estuvo bueno, pero no dio nada a largo plazo. O sea...”. Desde mi perspectiva, TICA había dado mucho más que un festival y se lo dije, él entonces matizó: "Sí, es todo aprendizaje”. Como pudimos ver, la experiencia, especialmente en su entrelazamiento con Recalculando, redundó en la obtención de recursos para los sellos miembros y de trabajos para algunos participantes: Nicolás y Juan pasaron a integrar el equipo de Recalculando y fueron contratados como trabajadores por el Ministerio de Cultura. TICA también movilizó perspectivas democráticas y de comunidad entre algunos músicos que hasta el momento sólo habían compartido "fechas" y saludos en la noche. Aún más: era innegable que las actividades de la red habían modelado una teoría de la situación y perspectivas de profesionalización que no estaban tan claras al comienzo de la experiencia. La evolución desigual de estas perspectivas, en un contexto de alta volatilidad de los proyectos, puede dar cuenta en parte del estancamiento de la red. El próximo capítulo relata la profesionalización desde Concepto Cero, lo que ayudará a entender mejor por qué para ellos en TICA se requería aún más nivel de profesionalismo. 


\section{La presentación de la Guía Rec}

Ya sin la interlocución de TICA, y en lo que respecta al período de la etnografía, esta aventura de redes, capacitación y trabajo que vinculaban la música con el Estado, terminaba con la presentación de Guía Rec en el MICA 2015, un 5 de septiembre en el Centro Cultural Kirchner a sala repleta, especialmente de jóvenes. Al libro lo habían presentado semanas antes en un encuentro de sellos de gestión colectiva realizado en Mar del Plata, donde algunos sellos que habían conformado TICA fueron de la partida. Martín Mena era el coordinador general del libro, junto a Bruno Maccari, quien también me fue presentado como su editor. Martín escribía uno de los capítulos junto a parte del equipo del programa -Nicolás, Juan y Antonela- sobre sellos de gestión colectiva. Por su parte, Nicolás se encargaba de otro sobre herramientas de marketing digital ${ }^{105}$. En la bibliografía de los artículos podía ver citados algunos libros que había encontrado en su biblioteca, lo que me hablaba de un clima de lecturas compartidas. Entre los expositores que acompañaban a Bruno y Martín encontrábamos otra parte del camino trazado en estas páginas: el español Tomás Guido, editor de Música para Camaleones y Johanna Pinzón, de Poliedro, la empresa colombiana del Manual para la creación de portafolios musicales.

Tras bambalinas, y mientras esperábamos que terminara una charla que protagonizaban productores musicales, Nicolás y Martín se paseaban visiblemente nerviosos mientras chequeaban con Tomás y Johanna los videos que iban a pasar y recibían visitas de personalidades célebres de la música como Tweety González, quien luego promocionó el libro en su cuenta de Twitter como "la biblia de los músicos argentinos" 106. Se vivían los nervios de un momento de reconocimiento. Martín y Nicolás estaban notablemente vestidos para ello, más formales que de costumbre: Martín a quien acostumbraba ver con jeans lavados y canguros de algodón vestía un jean oscuro, una camisa blanca con un estampado pequeño en negro, un suéter y zapatillas urbanas de cuero,

\footnotetext{
${ }^{105}$ Otros nombres no me eran desconocidos: el periodista del suplemento Si de Clarín, Mariano del Águila, quien Nicolás me había presentado como un amigo en 2011 daba inicio al libro; y le seguían actores del mundo de la música como Fer Isella, coordinador de aquella charla en el pre MICA La Plata del 2012, un nombre con presencia en las redes de Concepto Cero; Nicolás Wainszelbaum, el interlocutor en Provincia y Guillermo Navarro, quien fuera el abogado del sello durante varios años. Al resto los reconocía por estar estudiando temas musicales pero no porque me hubieran sido presentados en el trabajo etnográfico.

106 Tweet del 5 de 5 septiembre https://twitter.com/tweetygonzalez2/status/640309734684426240/photo/1
} 
Nicolás, afecto a la ropa deportiva, estaba con una camisa negra, un blazer negro, jean oscuro y zapatillas deportivas Nike, estas sí del estilo que coleccionaba y usaba desde que lo conozco.

En su exposición pública, Martín ubicó el comienzo de "nuestro camino como política pública" en sus viajes por el país, donde había descubierto un "nuevo actor": un "músico emprendedor, un músico gestor que lleva las riendas de su propia carrera". Estos músicos gestores se reúnen en "los sellos de gestión colectiva ${ }^{107}$, con los que trabajamos". En esta interacción con músicos y sellos, cayeron en la cuenta de que "es importante la formación en gestión" y es por ello que Recalculando "no da recursos económicos, sino asesorías en gestión". El libro se presentaba "ameno" a la vez que "profesional" y terminaba de instalar en la arena pública el tipo de trayectorias y estructuras en la música que venimos describiendo. Colocaba a un tipo específico de músico como interlocutor legítimo de la política pública, esto es el músico emprendedor o gestor, y al sello de gestión colectiva como la institución clave para las prácticas musicales emergentes. Desde la perspectiva de la Guía Rec, dichas prácticas habían llegado a un punto que requería profesionalización: en los diferentes artículos enseñaban -con ejemplificaciones de casos recogidos a lo largo del país- estrategias de gestión, nociones de marketing digital, comunicación y prensa para proyectos musicales, armado de estudios hogareños, derechos de autor y propiedad intelectual, entre otras herramientas que consideraban necesarias para saber moverse en el que llamaban "ecosistema actual de la música”.

\section{Una redefinición de la independencia}

Cuando en el año 2009 comencé a estudiar prácticas musicales adscriptas al indie, no imaginé jamás que apenas tres años después haría observación participante en eventos protagonizados tanto por músicos como por funcionarios y trabajadores culturales del Estado. Incluso en el mundo de la música indie que había investigado entre 2009 y 2011 , donde la categoría de independencia no era exactamente un regodeo purista en la oposición al mainstream o corriente principal, el Estado resultaba sospechoso pero más que nada ausente. Los vínculos entre las partes se limitaban a la contratación de artistas y muchas veces resultaban conflictivos. Con este diagnóstico, en una reunión privada un músico le

\footnotetext{
${ }^{107} \mathrm{Al}$ que diferenciaban del sello discográfico independiente. Desarrollo este concepto en el próximo capítulo.
} 
echaba en cara a un funcionario: "Los músicos independientes en los eventos en la provincia son la Cenicienta de los eventos, no cobran, son maltratados, mientras las bandas grandes cobran". Incluso durante el primer año de acompañamiento a Concepto Cero, dadas las malas experiencias con ciertas direcciones estatales, el Estado aparecía como un hostigador más que como un aliado. Estas experiencias, combinadas al calor del sentido común sobre la música independiente como un fenómeno alterizador, me habían predispuesto a pensar que en mi objeto las políticas públicas, y en general la política, no tendrían lugar.

Por el contrario, como vimos en las páginas anteriores, durante el período etnográfico comienza a distinguirse con nitidez una zona de coincidencia entre el creciente interés que distintas instituciones y actores oficiales prestan a la dimensión cultural con la atención que los músicos emergentes otorgan a las políticas sobre el sector. En efecto, se observó un movimiento general que va de una evaluación negativa por parte de los músicos de las escasas y ambivalentes políticas públicas culturales a regularidad del vínculo en diversos programas, que llega a la conversión de algunos músicos en promotores de programas estatales, en un proceso de ampliación de los modos de interlocución entre ambos actores. Estas relaciones, no exentas de conflicto, dejan de estar limitadas a la mera contratación de artistas -que también crece- para desplegarse con regularidad en políticas de promoción, incentivo y subsidio a los colectivos y artistas emergentes. Es verdad que no todos los actores se vinculaban con la misma cercanía, el mismo interés o la misma comodidad pero para ninguno el Estado era un actor ausente en su práctica musical.

Los sellos musicales inscriptos en TICA y el propio Concepto Cero al comienzo del trabajo de campo se definían como emprendimientos "independientes" y así eran identificados por el público y especialmente por la prensa. No obstante, el evento que llevó a TICA a la mayor convocatoria y visibilidad, el festival La Nueva Energía, fue anunciado a partir de los conceptos de lo "nuevo" y de lo "emergente": la categoría de independencia había desaparecido en esta instancia pública. Un detalle en la oficialización del programa Recalculando ya había evidenciado este punto. En el transcurso de las distintas capacitaciones y encuentros en los que participé, la independencia era una categoría muy usada por los músicos, y también por los promotores, para referir a los sellos y las actividades que estos realizaban. Sin embargo, cuando el programa encontró su eslogan 
eligió la categoría de emergente y no de independiente para calificar a la música que elegía promocionar y legitimar. La noción de independencia, poseedora de una carga semántica polisémica y vuelta un valor por el cual se disputa en ciertos mundos de la música, no resultó del todo pertinente. El desplazamiento a las nociones de lo "emergente" o de lo "nuevo" podía sostener las referencias al valor del riesgo y de la calidad estética, de los vínculos cooperativos, del trabajo en red, sin referir a una noción de lo independiente conflictiva cuando quien la instalaba era una política pública.

En ocasión de algunos intercambios en capacitaciones, pude ver que al interior de TICA se multiplicaban las definiciones de la independencia. Un músico de Güacho decía en una reunión que el modelo a seguir eran Los Redondos: "una banda re importante, que hicieron las cosas de modo independiente, y entonces yo pienso "si ellos pudieron es porque se puede...". Nada podía estar más alejado de la práctica de Concepto Cero, para quienes tanto Estado como privados tenían un lugar en las redes del sello. Mientras para Uf Caruf editar con licencias Creative Commons era una manera de sostener la independencia, a otros esto les parecía un mero ejercicio principista. Para un músico de Dice Discos, todo “depende de lo que quiera decir la independencia".

Para la mayoría, sin embargo, no era necesario hablar de independencia para referir a sus prácticas estéticas e incluso cuando sostenían dicha categoría esta había perdido su fuerte carácter alterizador y admitía compatibilidades que en otros casos históricos no ha admitido: con los grandes medios, con las grandes marcas, con los gobiernos, con las instituciones estatales. Acordaban que más allá del énfasis que cada cual le asignara, este concepto definía un amplio espectro de bandas, músicos y sellos que no formaban parte de las escuderías de las majors, pero no mucho más ${ }^{108}$. Esto debería llamar la atención de la bibliografía académica que en este campo de estudios construye el concepto de independencia desde los usos propios del grupo analizado, pero no da cuenta de dicho

\footnotetext{
108 Justamente, la mayoría de los textos refieren con "independiente" a los artistas y/o sellos que serían independientes de las grandes compañías, dada la ausencia de un contrato discográfico con algún sello major o propiedad de una major, aunque muchas veces dependan de ellos para la distribución (Shuker 2005, Yúdice 2008). Esta es una definición muy común que recorta un campo de gran diversidad: músicos que aún no han editado placas ni tienen relación con productoras y /o discográficas, músicos que han editado de forma casera, músicos que producen y/o distribuyen a partir de sellos como el que fue a pequeñas empresas con cierta cantidad de empleados), etc. Estas diversas relaciones con la industria discográfica son acompañadas de situaciones también muy heterogéneas respecto al uso de las tecnologías, las modalidades de profesionalización, las formas de la legalidad adoptadas, para no hablar de las estéticas disímiles que las acompañan, las retóricas más o menos politizadas, entre otras dimensiones de análisis.
} 
carácter específico y supone cierta generalidad en los usos encontrados (Corti 2009, Vecino 2011, Quiña 2012). Estos trabajos presentan la independencia como categoría aproblemática - punto de partida y no de llegada- y suponen que es posible aislar algún valor central que la definiría. Por ejemplo, Vecino (2011) entiende que el valor de lo artesanal y del riesgo definen "ideológicamente" a la independencia. Por el contrario creemos que esos valores entran en disputa sin cristalizar en ningún manifiesto que un mundo musical pueda firmar sin más. La definición de la noción de independencia es siempre objeto de conflicto.

Durante mi trabajo etnográfico fui testigo de una pequeña polémica suscitada por las relaciones novedosas entre el Estado y ciertos músicos y sellos independientes del tipo que he descripto en este capítulo. A partir de la publicidad de iniciativas como Recalculando, aunque no específicamente a motivo de ella, comenzó a circular entre los músicos una referencia malintencionada, la de "indie estatal". Esta expresión, levemente amplificada por el periodismo especializado y las redes sociales, pretende denunciar una situación de cooptación de los músicos por parte del Estado, en un olvido de que esta intervención estatal es posterior a la producción de todo aquello que sustenta las dinámicas de producción de esta música. Es verdad que esta incipiente relación con el Estado reorienta estas dinámicas hacia lugares que aún no es posible determinar, pero se asienta en instancias sociales de muchos años de acumulación. En este sentido, la incorporación por estos músicos de la gestión como un momento constitutivo y prácticamente irrenunciable de su práctica musical se ha planteado de forma independiente de la posibilidad de participar o asentarse en un circuito estatalizado. En otros contextos, por ejemplo en el de la música brasileña, este tipo de vínculos ha sido notado también como "estatalización" del circuito musical (Garland 2011, citado en Irisarri 2015). Frente a estas interpretaciones, otros trabajos avanzan en el concepto de "gestión compartida" en el que la noción de independencia asume un nuevo valor (Irisarri 2015). En este sentido, los músicos de Concepto Cero siempre decían que "el Estado es un actor más".

Por otra parte, es probable que esta acusación de indie estatal se correspondiera también a un momento de puja entre los músicos por la distribución misma de los recursos (pasajes, subsidios, etc.), sin olvidar que la presencia del recurso estatal no puede desprenderse de un proceso de revalorización de la música y las relaciones estéticas como 
lugar desde donde ejercer gobernanza. En este sentido, un músico me decía que "yo no tengo problema porque tengo lugares pero estaría enojado si viera todas las bandas de [nombre de un sello musical] tocando en Canal Encuentro". De la misma manera, en la presentación del pre MICA La Plata la editora de un conocido fanzine vinculado a los sellos musicales estudiados me confesaba que era "re opositora". En base a ello entendía que "a los de Garage [refiere a la revista De Garage, dedicada a "la música de La Plata" de circulación gratuita y mensual] les bajan guita, son re oficialistas, re K... acá a cualquier fanzine le dan 5000 pesos y a nosotros nada". Nuevamente el problema no estaba en que el Estado interviniera sino en cómo se interpretaba la asignación de recursos.

En el caso de Concepto Cero consideraran que este vínculo con el Estado no les daba suficientes conexiones y se planteaban "buscar privados". Las compañías privadas, como las alimenticias y telefónicas que organizaban los festivales Pepsi Music o Personal Fest, eran interlocutores habituales de los músicos independientes desde años atrás. Al igual que las cadenas de televisión MTV y Much Music en cuyos programas varios de los artistas que forman parte de esta etnografía han participado. En todos los casos, se trataba de eventos puntuales donde se invitaba a tocar a cambio de un caché o de publicidad. Lo que sí suponía una novedad era buscar trabajar con estas empresas, ya sea en el auspicio de los eventos propios -tal como en su momento Concepto Cero hizo con pequeñas empresas como Cabra 52, hostel Frankville y apostaba a hacer con Cynar- o en co-producciones, organización de eventos, etc. Los miembros más activos de Concepto Cero apuntaban a ello. Cristo y la "buena onda" con la marca de aperitivos Cynar no era el único caso, Nicolás ya había propuesto ofrecer auspicios a bebidas energéticas como Red Bull para fechas de Concepto Cero y para el festival de TICA, si bien ninguna de estas propuestas terminaron efectivizándose en el período etnográfico.

Curiosamente, el libro con el que inicié este capítulo describía muy bien la actitud que Nicolás y otros miembros de Concepto Cero tomaban: "El carácter maleable de estos camaleones, su capacidad de mutación constante, los hace ir de un lugar a otro en busca de recursos. Aquí entonces los sectores público y privado, que constituyen el financiamiento habitual de las iniciativas de este tipo en España, cobran mayor o menor relevancia en sus proyectos según qué casos. Una intención híbrida y puntual se hace necesaria, adecuada a cada situación y contexto...” (Trànsit Projectes 2012: 25). Al respecto de ambos vínculos, 
en una capacitación de Recalculando, Nicolás indicó “yo ahora trabajo para el Estado pero antes no lo hacía" y continuó "me parece que las fronteras con lo político, lo privado, están medio rotas". Su afirmación se perdió entre otras intervenciones y, si bien algunos músicos expresaron su desacuerdo en sus caras, el mismo hecho de que esta frase se perdiera entre otras me mostraba que no resultaba provocativa. Efectivamente, la difuminación de una actitud de puja absoluta tanto entre el arte y el mercado como entre el arte y el Estado era un hecho consumado. 


\section{Capítulo IV: Una música que se profesionaliza}

El viernes 20 de septiembre de 2013 me acerqué al Centro Metropolitano de Diseño en el barrio porteño de Barracas, sede del número de edición BAFIM, Buenos Aires Feria Internacional de Música. A las 15 hs. estaba anunciada una "mesa abierta de debate" titulada “Los 'nuevos' sellos discográficos independientes", con la participación de Sadness Discos, Scatter Records, Triple RRR Discos y Concepto Cero, la organización de Estamos Felices ${ }^{109}$ y la coordinación de Tatu Estela. Estas personas no me eran desconocidas: Bernardo, dueño de Triple $\mathrm{RRR}^{110}$, me había dado una extensa entrevista en el año 2010, además de verlo con regularidad en recitales de sus bandas en La Plata; a Tatu me lo habían presentado los chicos de TICA cuando disertó en un taller de Recalculando; al resto los conocía indirectamente por entrevistas periodísticas, además de que sus sellos solían aparecer en las conversaciones de Concepto Cero. Bandas de Sadness Discos y Scatter Records habían participado en "Los Ellos", mientras Estamos Felices era un sello histórico de la escena independiente. Los referentes de todos estos sellos aparentaban entre 35 y 40 años de edad, salvo Nicolás, visiblemente menor.

La charla empezó a las 15:15 hs. en una sala vidriada bastante pequeña, en la que no alcanzaron las sillas para la cantidad de personas convocadas. En principio la actividad no contaba con micrófonos pero pocos minutos después del inicio un asistente pidió a los disertantes si podían hablar más alto. Un empleado de la organización trajo entonces dos micrófonos con los que se desarrollaron el resto de las exposiciones. El presentador Tatu Estela ensayó una justificación: "esperábamos algo más íntimo", dijo para dar cuenta de cómo la convocatoria había excedido sus previsiones.

Martín Mercado comenzó la ronda de exposiciones desde su papel como "director" del "sello" y "productora cultural" Estamos Felices. Martín dijo que un sello además de

\footnotetext{
${ }^{109}$ Estamos Felices se define como un "sello DIY" (Do-It-Yourself). Es también una agencia de booking y management y brinda servicios de consultoría. Opera en la CABA desde el año 2004.

${ }^{110}$ Triple RRR es un sello discográfico con sede en el conurbano sur y en actividad desde el año 2009. En su catálogo figuran bandas muy conocidas de la escena como Valentín y los Volcanes, Viva Elástico y Los Reyes del Falsete, además de los trabajos de Juan Irio (The Siniestros) y de bandas menos conocidas pero respetadas en el ambiente como DChampions, Mármol R y Sub.
} 
dinero pretendía "generar imaginarios culturales" y resaltó su trabajo con "sellos de afuera" - esto es, del exterior del país. Luego, un poco en broma y otro poco en serio, afirmó que los sellos son como los "papis" de los músicos. Por su parte, Janín Madian Chade se presentó como el "director" de Sadness Discos y "manager" de su grupo de bandas, "una comunidad que trabaja desde 1996". Contó que habían empezado organizando recitales, en una "época adolescente anarquista" y que ahora se podían considerar un "sello establecido", pero que mantenían los principios de un "movimiento autogestivo" y de "trabajar todos en comunidad hacia el mismo lugar", donde "si la banda no llega a la masividad no nos preocupa”. Siguió Nicolás Madoery, quien dijo que Concepto Cero había surgido cuatro años atrás a partir de un interrogante compartido con algunos "amigos", a fin de contar con "una plataforma para hacer nuestros propios discos, nuestros propios eventos". Dijo entonces algo que lo diferenció del resto: "también soy músico" y contó que tenía una banda, la cual estaba un tanto "oxidada", pero ahí estaba. Dentro de la ciudad de La Plata y su escena situó la práctica de "trabajar en red con otros sellos", con quienes habían hecho dos festivales. A continuación, Bernardo Diman Menendez se presentó como "director" y "editor" de Triple RRR, un sello inspirado en el "modelo de Silicon Valley" que había empezado en 2008 con algunas "producciones" para en el 2009 empezar a "editar discos". Habló de la posibilidad y de la existencia de "música masiva digna" que era justamente a lo que apuntaba su sello, una música que pudiera gustarle, en un parafraseo de una frase suya que ya le había leído en entrevistas, "a un operario de Remedios de Escalada y a una chica de Recoleta". Por último, habló Pablo Hierro de Scatter Records para contar que "mi sello nació hace diez años", pero luego de un trabajo de tanto tiempo en el cual cometió varios errores "ahora sí soy un sello discográfico". Estableció que él no venía del "negocio de la música", más bien se consideraba un "melómano". Afirmó que "estaban en contra de firmar contratos" y que con sus bandas el arreglo era "de palabra". En esta línea, en la previa de los shows "la onda es jugar a la play en mi casa", ya que "soy amigo de todas las bandas". Comentó que administra su propia editorial, a la que "entra dinero y creo que va a ser cada vez más", a pesar de lo cual, agregó, "no me siento un empresario de la música" 111.

\footnotetext{
${ }^{111}$ Cada uno de los disertantes se explayó sobre varios otros temas que no hacen al argumento que se quiere introducir y que por lo tanto he omitido en esta reescritura de las notas del diario etnográfico.
} 
Luego de las presentaciones, Tatu invitó al público presente a hacer preguntas: la organización interna de los sellos, el éxito de las bandas argentinas en el exterior y, entre otros, las políticas culturales de la escena chilena en comparación con la Argentina, fueron algunos de los temas de interés. A partir de uno de estos interrogantes, los panelistas pudieron aclarar que no vivían de la música en un sentido tradicional: Martín Mercado planteó: "Nosotros nos auto-sustentamos, hacemos shows internacionales, trabajamos el negocio de la música pero no el de los discos". Nicolás, por su parte, afirmó que el sello en sí mismo "no genera valor y dinero para vivir" pero estar en el sello abre otras oportunidades que sí pueden dar dinero. Pero entre los comentarios del público, hubo uno que ayudó a precipitar una diferencia clave entre los distintos directores de sellos. Un joven pidió la palabra para afirmar que en su opinión los sellos existían porque el músico debe poder dedicarse a tocar: "producir música, producir arte”. Mientras terminaba de hablar, algunos de los panelistas le daban la razón con gestos de asentimiento. Enseguida, Nicolás pidió el micrófono para contestarle que no estaba de acuerdo, ya que "ese es el modelo del rock star" y "las nuevas tecnologías permiten pensar otro tipo de músico". Unos minutos más tarde, en cierta oposición con este concepto, Bernardo expresaba que "no hay nada peor que un músico que es un manager".

En un momento avanzado del debate, tuvo lugar otra pequeña polémica iniciada por una joven parte del equipo de Recalculando. Ella se acercó a las primeras filas de sillas y pidió el micrófono para preguntar: "pero el modelo de ustedes al fin y al cabo no es tan exitoso, ¿no es el momento de crear un nuevo modelo?’. Enseguida Bernardo retrucó "Recalculando tampoco es muy exitoso". Mientras parte del público se reía ante este cruce entre ambos, ella aclaraba no creer que no sean exitosos, pero dado que son los "referentes" -y por eso, enfatiza, "están en esta mesa"-, deberían "fomentar, potenciar" dichos "nuevos modelos", que "no son antagónicos" con los de ellos ${ }^{112}$. Martín contestó que justamente por eso lo invitaron a Nicolás: es representante de esos otros modelos. Luego sintetizó que los dos tipos de proyectos en cuestión surgen de necesidades diferentes, y mirándolo a Nicolás, afirmó que esos sellos nacieron de la necesidad de auto editarse, lo que no fue así en el caso de Estamos Felices ni de otros sellos que compartían la mesa.

\footnotetext{
${ }^{112}$ Los otros sellos de la mesa, salvo Triple RRR, tenían una mayor cantidad de años de actividad. En efecto, Pablo de Scatter Records se refirió al título de la charla: "Nuevos no somos, hace años que estamos". Luego agregó que le parecía un tanto "insultante" hablar de su sello en términos de novedad.
} 
Hacia el año 2014 este "nuevo modelo" al que referían la integrante de Recalculando y Martín Mercado comenzaría a ser conceptualizado por Recalculando a partir de la noción de "sello de gestión colectiva". De esta manera, la Guía Rec afirmaba que mientras "en los sellos independientes tradicionales el director o responsable reúnes artistas que no se conocen entre sí (...) el modelo de gestión colectiva consolida vínculos ya existentes y promueve iniciativas conjuntas entre creadores y emprendedores que ya compartían escenas o colaboraciones (Recalculando 2015: 97). En cuanto al desempeño y forma de trabajo de un sello de este tipo afirmaban que "las funciones principales de un sello de gestión colectiva coinciden, a grandes rasgos, con las de un sello independiente, sólo que debido a las dinámicas de trabajo y los objetivos y formatos de sus proyectos, los SGC se organizan y gestionan de una manera distinta, más cercana a esquemas de trabajo horizontales, en los que sus participantes ponen a disposición recursos y saberes de forma colaborativa" (Recalculando 2015: 97). El equipo identificaba al menos 40 sellos activos de este tipo, a los que había conocido y relevado desde los viajes realizados por todo el país. Estas definiciones resultan cercanas a las que planteé en mi tesis de maestría (Boix 2013) para los sellos emergentes, donde la edición de discos pierde centralidad y la amistad es el lazo social clave. La idea de un sello de gestión colectiva producía una distinción que yo no había contemplado y que la forma en que se presentaba Pablo de Scatter muestra con claridad: él es amigo de todas las bandas pero eso no quiere decir que su sello sea de gestión colectiva. En contrapartida a esta precisión, la idea de la gestión colectiva podía opacar los poderes desiguales de los distintos miembros del grupo para ejercer dicha gestión.

Esa tarde en BAFIM, el debate establecía un nosotros/ellos entre los sellos emergentes y los sellos discográficos independientes de más larga data. Nicolás valoraba en un chat posterior que mantuvimos esa misma noche que dicha oposición binaria no permitía "ver la industria como un todo", donde los sellos de gestión colectiva como los de TICA tenían una participación. Como había dicho Lucio de Dice Discos en una de las reuniones de la red: "Nosotros ya estamos dentro de la industria, del mercado, pero con un papel marginal y pobrísimo". Pero más allá de las distinciones entre dos modelos, el debate en BAFIM ponía de relieve las conexiones entre los sellos realmente existentes -en la combinación de actividades discográficas y de producción, en la forma como entendían que 
hoy se podía "vivir de la música"-, a la vez que la variedad de estructuras en las que se presentaban y de concepciones sobre los músicos y la música que activaban. En este panorama no todos los sellos que se consideraban "empresas" resultaban ser sellos editoriales, no todos los sellos que firmaban "contratos" ganaban dinero - iy algunos que no lo hacían sí obtenían réditos!- ni todos los sellos que hacen gala de la "amistad" eran de gestión colectiva.

Asimismo, este debate ponía en escena, en el propio mundo de la música independiente, la emergencia del tipo de instituciones y de prácticas musicales que en esta tesis analizo: un sello de nuevo tipo, que igualmente podía aspirar a la profesionalización y que en esa pretensión producía perfiles profesionales diferentes. La propia trayectoria de Concepto Cero durante el período, en una notable aceleración a partir de fines de ese mismo año, iba a mostrar una manera específica de la forma sello en la que un proceso de profesionalización se combinaba con un registro de motivos propios del sello plenamente de amigos y de pares, en el que la gestión es colectiva y el músico es un sujeto que no necesita "papis" aunque sí un grupo que trabaje con él. Ese grupo acompañante constituía también sus bandas y estaba conformado por personas como Nicolás, que no se sentía cómodo en las categorías de manager, melómano ni empresario, a la vez que pivoteaba entre actividades que podían subsumirse a dichas nociones y sus actividades como músico.

En este capítulo relataré un proceso multidimensional de profesionalización, que atraviesa las estructuras y recursos del sello y las competencias y especializaciones de los músicos implicados. Dicho proceso es conceptualizado por los participantes de Concepto Cero bajo la imagen de un camino en el que comienzan a alejarse del formato de un sello gestionado entre amigos para acercarse a prácticas "empresariales". Esto supuso por un lado la expansión de las actividades creativas del sello en busca de una marca profesional, por el otro la organización del trabajo y el desarrollo de alternativas profesionales en las trayectorias de los distintos participantes. La centralidad de la gestión para estos músicos y el cambio concomitante en la categoría misma de músico nos dan la clave para entender este proceso de profesionalización, que se desarrolla en relación con una tensión específica que distingue a los músicos gestores del resto de los músicos de la escena emergente. 


\section{Ser "profesionales"}

En una entrevista a la edición web de la revista Los Inrockuptibles realizada en el año 2015, Nicolás decía con respecto a "Los Ellos": “A partir de ahí hubo un quiebre de profesionalización" ${ }^{113}$. En efecto, a lo largo del trabajo etnográfico pude percibir cómo los miembros de Concepto Cero que persistían en la red se esmeraban por producir acciones musicales de un modo "prolijo", "comprometido", "profesional" e incluso, para Nicolás, como lo haría "una empresa". El resultado los posicionó visiblemente en la escena independiente como un sello "pro" o "profesional", tal como me decían algunos habitués con los que conversaba en los eventos. "Todas las movidas que hacen estos chabones son siempre muy pro", me comentaba en la fiesta del tercer aniversario de Concepto Cero (2012) una participante de la escena, que había tenido bandas y trabajaba en la "taquilla" o la "puerta" para algunos grupos rockeros que tocaban generalmente en pequeños bares de la ciudad como Pura Vida. Por más que para ella las fechas en las que trabajaba tuvieran su "encanto", en dicha fiesta en el Galpón de La Grieta ${ }^{114}$ había escenografía, un "kit de fiesta" 115 para las primeras 100 entradas, un proyector "de puta madre" -como me dijo orgulloso Nicolás- y la llegada a La Plata de Fantasma, una banda en ascenso de cumbia electrónica de la CABA que nunca había tocado en la ciudad ${ }^{116}$. Esa misma noche me encontré entre los bailarines a un compañero de la maestría, quien ya enterado de mi objeto de investigación, me preguntó: “¿tienen plata?... está re bien el sonido, con semejante sonido... suena bárbaro". Semanas atrás, en una reunión en el hostel, Cristo y Nicolás nos habían mostrado, a JP de Ciudad Alterna y a mí, el programa cronometrado del evento en una tabla en Google Drive, con los horarios para tocar de cada banda. JP había dicho: “isiempre todo pensado, todo armado!”. La planificación y la calidad técnica de los eventos

\footnotetext{
${ }^{113}$ Zanellato, R. (2015). "Los sellos musicales: Concepto Cero, un punto de partida"", en: Los Inrockuptibles, 21 de julio de 1015. Disponible en la web: http://www.losinrocks.com/musica/concepto-cero-un-punto-departida\#.VrQKJdLhArg.

${ }^{114}$ El Galpón de Encomiendas y Equipajes del grupo cultural platense La Grieta está ubicado en el barrio Meridiano V, en el límite del "cuadrado" de la ciudad de La Plata, y tiene una capacidad de alrededor de 500 personas. En los primeros años del período etnográfico era un lugar donde solían hacerse fiestas y recitales.

${ }^{115}$ Consistía en un sobrecito transparente con unos recortables de Tormenta, unos gorros de plástico de cotillón, guirnaldas de plástico para adornar el cuerpo y otros implementos de esa clase.

${ }^{116}$ El componente de novedad había sido pensado por Cristo y Nicolás, quienes habían negociado con el grupo un caché bastante más bajo que el usual para un grupo de esas características sumado al alojamiento en el hostel Frankville. Repitieron la estrategia en una fiesta de aniversario posterior en la que invitaron a El Chavez pero que finalmente tuvo que suspenderse por la magnitud de las inundaciones de La Plata de ese mismo año.
} 
realizados por Concepto Cero resaltaba al interior de la escena y era un aspecto visible de la profesionalización para sus participantes.

El trabajo al interior de Concepto Cero me mostró cómo en el período estudiado apuntaron a una serie de mejoras en la organización y los resultados de sus acciones musicales que excedía ampliamente los eventos, porque los incluía en una planificación "integral", tal como la llamaban, con los discos, la comunicación y la prensa, el estilismo, las artes audiovisuales, entre otras dimensiones de acuerdo al caso. La producción completa vinculada a "Sueño Real" el segundo disco de Shaman y los Pilares de la Creación ${ }^{117}$, lanzado en el año 2015 al término del trabajo etnográfico realizado, evidencia el plan "integral" en el que comenzaron a embarcarse con cada artista. Para el caso de "Sueño Real" el sello estuvo presente en todas las etapas, desde el "craneo" del álbum y el cronograma de su realización a comienzos del año 2014 hasta la presentación más de un año después del disco en el Centro Cultural Caras y Caretas, en pleno centro porteño, lo que revelaba también un cambio en el centro geográfico del sello, que como veremos en el próximo capítulo no tenía tan claro su carácter de sello "platense". Durante todo el 2013 ya se conversaba de este disco y de la posibilidad de que los músicos viajaran a México para grabar el álbum con Ernesto "Neto" García, productor, ingeniero y colaborador de Julieta Venegas, Los Bunkers, Natalia Lafourcade, entre otros artistas de proyección en toda Latinoamérica. Los integrantes del sello había comenzado a buscar subsidios para realizar este viaje pero finalmente decidieron hacer la grabación en Argentina, y usar en principio dinero del sello para financiar el viaje y la estadía del productor mexicano, el cual luego podría recuperarse a partir de algún subsidio ${ }^{118}$.

Mientras en el año 2010 Nicolás me había dicho que los discos los grababan "cada uno como puede", "Sueño Real" fue grabado en distintos estudios de La Plata y la CABA, además de ser producido por un productor de proyección internacional. Esto resultó

\footnotetext{
${ }^{117}$ La relación con este artista había comenzado en el año 2011 a partir de su participación en el compilado "Los Ellos" con su anterior formación de banda Shaman y los Hombres en Llamas, con la que tocó en las presentaciones del disco en La Plata y en CABA. Hacia el año 2012 Nicolás entró en conversaciones con él por la cuestión de la red de sellos, luego de lo cual fue invitado a tocar a Sonido Expansivo. En la continuidad de este vínculo, Shaman ingresó al sello, formalizándose su entrada en febrero de 2013 para toda la "crew", con mensajes en el grupo privado de Facebook y luego un asado de festejo.

${ }^{118}$ Específicamente se presentaron a la convocatoria del año 2014 del Fondo Argentino de Desarrollo Cultural, Línea Sostenibilidad, Modalidad Apoyo a la promoción de catálogos de sellos discográficos independientes, pero no resultaron beneficiarios. Algunos sellos que habían participado de Recalculando, como Mamboretá Psico Folk Records, o que participaban de la escena de La Plata, como Discos Laptra, estuvieron entre los ganadores.
} 
relativamente inédito para Concepto Cero -y por lo tanto promocionado como tal- pero no impensable: ya para el disco "Los ellos", editado en el año 2011, intentaban condicionar la calidad de la grabación de las distintas canciones -al proponer a las bandas la posibilidad de grabar en el estudio Tolosa, a la vez que se hacían cargo de una masterización única para todos los temas. El interés por la calidad en las condiciones técnicas de grabación, mezcla y masterización de los discos se volvió cada vez más relevante durante el período ${ }^{119}$. Así, en las conversaciones sobre "El espíritu", el disco de El Perrodiablo editado en el año 2012, se repetía que la banda tenía mucha potencia en vivo la cual no se veía reflejada en sus discos anteriores. Acordábamos con varios miembros de la "crew" en que el audio de esos discos no era de buena calidad, al punto de que no los escuchábamos. De acuerdo a Nicolás los propios músicos de la banda habían quedado bastante impresionados de cómo podían llegar a sonar escuchándose en el tema producido para el compilado. Justamente la idea que habían conversado era sacar un disco de la banda desde Concepto Cero que sonara como esa canción. En la misma tónica, al año siguiente, el primer disco de la formación Shaman y los Pilares de la Creación era post-producido y masterizado por Daniel Melero, interesado personalmente en el sonido de este artista. Más adelante, "Hilario" de Mariana Paraway fue masterizado por Andrés Mayo, un ingeniero de sonido muy reconocido en el ambiente musical. Estas decisiones de producción fueron acompañadas por otras relativas al packaging de los discos que en algunos casos incluyó ediciones limitadas "de luxe".

En el año 2014, en el estudio de Tolosa tuvo lugar lo que llamaron "prueba de grabación"; Nicolás se había implicado en toda la organización con Neto, Matías y Germán. ${ }^{120}$. Estos dos últimos jóvenes conformaban lo que Shaman denominaba su "equipo de trabajo". Como había observado en algunas reuniones, Matías y Germán gestionaban las fechas y las redes sociales para Shaman y los Pilares que también participaba de la

\footnotetext{
${ }^{119}$ En la misma situación se encontraban varias figuras de la escena: a fines del año 2012, Él Mató A Un Policía Motorizado lanzaba su primer álbum propiamente hi fi, grabado en los estudios Ion; en el año 2014 Un Planeta presentaba un disco -"Refugio"- grabado en Ion mientras el primero lo habían hecho en sus casas. Incluso 107 Faunos, un grupo emblema del indie platense asociado a cierta desprolijidad en el sonido pasaba a grabar en estudios Ion y a masterizar en Puro Mastering para su álbum "Últimos días del tren fantasma", editado en el año 2014. Finalmente, en esta serie que no pretendo que sea exhaustiva, sino indicadora del interés en un sonido "profesional", el último disco de Valentín y los Volcanes -"Una comedia romántica"-, editado en el año 2015, fue producido por Tweety Gonzalez.

${ }^{120}$ Germán ejercía el periodismo en radios locales y lo conocí como participante de las capacitaciones de Recalculando. Junto a Matías, participaba de la Revista Leche, una publicación gráfica con contenidos periodísticos a la vez que un fuerte interés audiovisual orientado hacia la música indie. Esta revista, con sede en la ciudad patagónica de Río Negro, tiene distribución en ciudades de la Patagonia pero también en Capital, La Plata, Rosario, Villa María y Tandil.
} 
producción de los videoclips, del disco, de las fechas, de las giras y de otras aventuras en las que el grupo se involucrara. El día de la grabación el grupo completo se había encargado de varias tareas: desde la compra de comida para los músicos hasta la organización de los horarios del estudio, pasando por la confección de planillas en cartulinas blancas con las distintas canciones del disco, usadas para especificar en distintas columnas las "estructuras" de cada tema y las "particularidades" divididas en diferentes dimensiones (base/ colchón/ pads -ritmo/ melodía/ fills/ arreglo/ invitados). Junto a Nicolás estaba Juan, quien se encargaba de realizar videos para el sello: tenía a su cargo documentar a la banda en acción en el estudio para luego armar materiales promocionales del disco. La idea era hacer una prueba de grabación para el viernes de la misma semana hacer la grabación final en el estudio Ion, en la que nuevamente miembros de Concepto Cero participaron activamente. Asimismo, el sello estuvo implicado en los trámites legales que debieron hacerse en SADAIC, CAPIF y AADI ${ }^{121}$, instancia de la que generalmente se hacían cargo ya que, como señalaba Ángel, incluso a los músicos más "hormiguitas” y gestores de su propia carrera les da "paja" hacerlo. Esta instancia formaba parte de una más abarcativa de formalización legal en la que se involucraron a partir del año 2013, sobre la que ampliaré más adelante.

También entre distintos integrantes del sello se encargaron del diseño las piezas gráficas del packaging del disco y de la comunicación con el sello nacional Ultra Pop para organizar la distribución del álbum, además de ubicarlo en el sistema propio de disquerías especializadas $^{122}$, las ferias de discos de sellos de los "amigos", la plataforma Mercadolibre y Spotify, iTunes, Amazon.com, Deezer, Last.fm y otras plataformas. La promoción incluyó un video-lyric correspondiente al tema "Sueño real" que funcionó como adelanto del disco. El encargado de editar los títulos que iban cambiando con el correr de la letra fue Javier, el $\mathrm{Vj}$ de Concepto Cero que presentaré más adelante. Antes del lanzamiento, la promoción continuó con un video que documentaba la grabación y las colaboraciones vocales de Santiago Barrionuevo de “Él Mató...”, Sara Hebe, Mene Savasta Alsina y

\footnotetext{
121 SADAIC gestiona los derechos de autor, CAPIF los derechos del productor sobre una producción discográfica en tanto esta sea "legal" -es decir, replicada-, mientras AADI hace lo propio con los derechos de los intérpretes. En este contexto, el organismo AADI/CAPIF recauda los derechos de la música grabada en sus usos en radio, televisión, cine y cualquier lugar -físico o no- donde esta se reproduzca.

${ }^{122}$ La distribución de los discos es uno de los problemas clásicos de los sellos independientes. Los acuerdos de Concepto Cero en las disquerías específicas cubrían las ciudades den La Plata, Capital Federal, Córdoba, Mar del Plata, Salta, Comodoro Rivadavia y Necochea.
} 
Marina Fages, entre otros. El Pampa se encargó de los flyers para la presentación en la sala Caras y Caretas, a la que una comitiva compuesta por Shaman, músicos de los Pilares y del sello fue a visitar con anterioridad a la presentación. De esta manera, podían planificar de forma más detallada la performance sobre el escenario y el diseño de escenografía y visuales.

Para difundir el lanzamiento del disco contrataron a Romina, una profesional de la prensa que se encargó de ubicar el lanzamiento en varios medios estratégicos: antes y después de la presentación, notas sobre Shaman y los Pilares pudieron leerse en la revista especializada en cultura rock Los Inrockuptibles ${ }^{123}$, en el suplemento $N O$ del diario Página $12^{124}$, en el suplemento de espectáculos del diario Clarín $^{125}$, entre otras revistas y periódicos de circulación nacional. Desde al menos fines del año 2012 que en las reuniones Concepto Cero se diagnosticaba que con las redes sociales virtuales no sería suficiente por lo que se ocuparon, por diversas vías, de contar con personas especializadas en comunicación y prensa. Con respecto a la tarea de estas personas contratadas, Ángel me explicaba: "Lo que armamos es un equipo donde hay una persona de prensa, Nico y yo. No es que la persona de prensa diseñe todo. Otra vez: tenemos todo el diseño general, y la persona de prensa activa (...) Y después, a veces los artistas tienen un equipo que trabaja con ellos y tratamos de que se sumen". Estos equipos estaban conformados por amigos, lo que demostraba nuevamente que en el camino de volverse profesionales los lazos de amistad tenían un lugar preponderante.

La búsqueda por parte del sello de la prensa tradicional, que había empezado bastantes años antes e incluyó una reunión con "prenseros" a los que finalmente no se convocó, mostraba que los proyectos emergentes en un camino de profesionalización y de búsqueda de expansión del público no podían depender sólo de las redes sociales virtuales, las cuales igualmente mantenían su centralidad. Entre los planes para esta expansión se encontraba la acción de ir al encuentro, por distintos medios, de los fans: como se definía

123 "Sueño real, de Shaman y los Pilares de la Creación" (28/08/15). Disponible en la web: http://www.losinrocks.com/musica/sueno-real-de-shaman-y-los-pilares-de-la-creacion\#.VoWam7bhArg ${ }_{124}$ "Escribo en estados de conciencia total y de inconsciencia total. Entrevista a Shaman Herrera" (23/09/15). Disponible en la web: http://www.pagina12.com.ar/diario/suplementos/no/12-8029-2015-0923.html.

$\frac{23 . h}{125}$ "El despertar de un nuevo sueño" (17/09/15). Disponible en la web:

http://www.clarin.com/extrashow/si/Shaman_y los_Pilares de la_Creacion-Teatro_Caras_y_CaretasSueno_Real_0_1432657220.html 
en una reunión del sello "hay que identificar a la gente que te likea todo, te sigue, es incondicional, que no son tus amigos ni tu papá...". Este "trabajo artesanal" había que hacerlo para cada proyecto, y miembros del sello lo implementaron a partir del año 2013 en el ciclo Sonido Expansivo empleando a una joven que ofrecía a los asistentes dejar su dirección de mail para recibir novedades del ciclo. Otra estrategia de expansión de público resultaba más indirecta y empezó a implementarse a partir de las co-ediciones con otros sellos. Así, el disco de Damián Anache, "Capturas del único camino” (2014), fue coeditado con Inkilino Records ${ }^{126}$, debido a que era un material "de nicho" al que se ese sello se dedicaba. En la misma lógica, Ángel me contaba al término del trabajo etnográfico que planeaban co-editar el próximo álbum de su banda, "los Polares", con Scatter Records "porque me parece que es un perfil en el que Polares calza más, viste, está Fantasmagoria, está Valle de Muñecas. Y no sé si como que Scatter ponga plata porque no creo, pero sí poder meter a Excursiones Polares en la movida de ellos...”. Las palabras de Ángel indican que del otro sello no se esperaba ni financiamiento ni recursos, sino una ampliación de la difusión del material y del artista en escenas que se creían estilísticamente más próximas.

El sello intervino también en la imagen de los músicos de Shaman y Los Pilares de la Creación a partir de un trabajo de "estilismo" con Eduardo De Crisci ${ }^{127}$. Nicolás me contó que como él este joven diseñador de indumentaria había cursado en el Bachillerato de Bellas Artes de la UNLP, pero que era unos años mayor. Nunca habían sido amigos pero siempre habían mantenido conocimiento de lo que hacía el otro, por lo que lo había contactado y "se había copado". Luego de algunas reuniones con la banda y miembros del sello, De Crisci armó distintos vestuarios que se lucieron en las fotos promocionales de Sueño Real -y antes en las de Quimera, el disco anterior de la banda y banda sonora de una película $^{128}$. Esta intervención estilística cambió notablemente la imagen "relajada" de la

\footnotetext{
${ }^{126}$ Inkilino Records es un sello de la CABA dedicado a la música electrónica experimental con cierta proyección internacional en la escala de estas escenas -motivo por el cual en su página web todos los textos se brindan tanto en español como en inglés. Además promociona las presentaciones de discos de los artistas del catálogo y organiza fiestas del sello.

${ }^{127}$ Eduardo de Crisci es un joven diseñador de La Plata con reconocimientos internacionales y locales. Cuenta con pasarelas en la New York Fashion Week y presentó sus colecciones en México DF, Milán y otras capitales de la moda. Trabajó en el diseño de producto y jefe de varias empresas textiles argentinas. Actualmente tiene una etiqueta a su nombre, tal como puede leerse en su propia presentación: http://www.decrisci.com/quienessomos/.

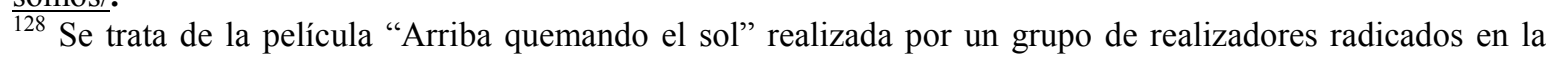
ciudad de La Plata.
} 
banda que, como otras de la escena independiente de La Plata, no diferenciaba la ropa a vestir abajo y arriba del escenario ${ }^{129}$. En su caso, las camperas de algodón con capucha o de gabardina con bolsillos, las remeras de algodón y las zapatillas de lona conformaban un estilo absolutamente despreocupado. De Crisci propuso túnicas negras, pantalones de jean negros, sacos y capas de sastrería acompañados generalmente de zapatos. El resultado eran conjuntos monocromáticos con predominio del negro, donde se observaba la repetición de formas y motivos en la vestimenta de los músicos entre sí. Si bien al principio Shaman "no había entendido si tenía que desfilar" y Nicolás le retrucaba "eso es lo que querés vos" frente a las risas del resto de los músicos, la idea era que la banda tocara en las pasarelas del diseñador en la CABA. Edu se había "copado" tanto con el grupo que repartía sus discos entre los críticos de moda que iban a sus desfiles. La relación del sello con este diseñador de moda redundó en participaciones en eventos de Concepto Cero en La Plata, entre ellas algunas fechas de Shaman, en las que De Crisci pasó música.

El 19 de septiembre de 2015, día de la presentación del disco "Sueño Real", todos los miembros activos del sello estaban presentes: Nicolás, Ángel, el Pampa, Anache -quien se encargó durante un tiempo de la feria de discos del sello, donde también vendían remeras y posters de "Sueño real" a precios promocionales- y Juan Artero. Los dos primeros se hicieron cargo de toda la producción del evento al punto de que paseaban con handies por arriba y abajo del escenario. También se encontraban algunos músicos que habían hecho participaciones en el disco y otros que se encontraban en el catálogo. Habían contratado a un fotógrafo que no frecuentaba las redes del sello. Hacía tiempo que la fotografía se resolvía puntualmente en cada situación, ya que como me decía Nicolás desde el año anterior "Cata está muy difícil de ubicar", además de que los trabajos de otros fotógrafos con los que habían entrado en relaciones "nunca nos terminaron de cerrar".

Entre el grupo del sello, el balance de la fecha se hacía enfatizando el carácter profesional. Decía Ángel: "Para mí, Shaman, el otro día lo vimos tocar (...) y todo era profesional. Todo era profesional y para ellos fue un placer. Estaban contentos ellos porque sonaba bien, tenían todo... O sea, es otra cosa, viste. Y aparte vos ya (...) le estás

\footnotetext{
${ }^{129}$ No vestirse de una manera especial para subir al escenario ni privilegiar "tocar con zapatillas nuevas", tal como fue definido en una entrevista, era una de las maneras en que los músicos del indie platense estudiados en el período 2009-2011 practicaban su carácter "relajado" con el que se diferenciaban de otros músicos de la escena platense. Los músicos de Shaman y los Pilares de la Creación formaban parte de ese circuito "indie" en dicho período.
} 
proponiendo a la gente otra forma de escucharte. Y verlo a Shaman en el teatro con un iluminador, con unas visuales, terminando el show cantando un tema con un piano. Es una experiencia que no tiene nada que ver con ir al $\operatorname{Zas}^{130} \ldots$ no digo que no va a tocar más en el Zas, pero digo, hay que apuntar a que él tenga un show así. Es re difícil, porque para eso tenés que justificar un montón de tickets cortados...”. Sobre los músicos decía algo similar: "El otro día flasharon, porque claro...vos soñás algo como músico, decís "quiero esto" y una vez lo experimentás y decís “yo quiero tocar siempre así”, ¿no?”. No obstante, en un botón de muestra de la dificultad a la que refería Ángel y de la falta de estabilización de este punto de llegada, luego de esta fecha Shaman y los Pilares se embarcaron en una gira patagónica por bares de pueblo y de playa que distaban bastante de los términos profesionales con que se había realizado la presentación del disco.

Como vemos con "Sueño real” la producción de un disco comenzó a asumirse casi totalmente por Concepto Cero junto al artista - con variaciones según los casos, ya que no se trata de una práctica estandarizada. La pre-producción, la grabación, la mezcla y masterización, el packaging, la fabricación, los trámites legales, la difusión y prensa, la presentación en vivo, el vestuario y la distribución y ventas pasaron de alguna manera por el sello. En otras palabras, entre los años 2013 y 2015 Concepto Cero comenzó a trabajar el proceso completo de producción de la mayoría de los discos, a la vez que se encargó de financiarlo en distintos porcentajes de acuerdo al arreglo alcanzado con el artista, situación excepcional para los sellos "independientes" surgidos en la zona metropolitana entre los años 1998 y 2010, los cuales no solían proveer a los artistas de estudios de grabación, equipos ni instrumentos, incorporando discos ya producidos por ellos (Vecino, 2011). En efecto, el resto de los sellos emergentes con los que compartí el trabajo etnográfico en el período no se encargaban de los gastos de producción discográfica ni de los trámites legales que conllevaba. Estos gastos y trámites pasaban, en diferentes grados, por las propias bandas (Boix, 2013) ${ }^{131}$. Pagar los discos era una aspiración compartida por algunos sellos de TICA. En este sentido, Diego de Desde el Mar proyectaba en el verano del año 2013:

\footnotetext{
${ }^{130}$ Refiere al Centro Cultural Zaguán Sur (“Zas”), conocido también como "el zaguán”, sala de conciertos orientada al rock, en la que suelen tocar bandas de la "escena". Para un periodista y miembro de una banda de la escena, este lugar es "el último antro". Nicolás Lantos (2014). "Zas, el último antro". Disponible en la web: http://lanan.com.ar/2014/03/zaguan-sur/

${ }^{131}$ Sí la mayoría de estos sellos pasó a encargarse de la distribución, a partir de acuerdos con distribuidoras o estrategias de distribución en unión con otros sellos de su clase, tal como hicieron quienes participaron en TICA.
} 
“...quizás el año que viene si nos va bien e ingresa mucho más dinero, haya una caja que permita que el próximo disco que saque el sello lo pague el sello, y ahí ya ganamos un terreno, que no es la banda pagándose su propio disco... quizá pueda llegar a pasar algo as'́".

En el caso de Concepto Cero, a partir de la producción de eventos para terceros, aumento en las ventas de entradas y discos y obtención de subsidios, el sello comenzó a manejar otros números que posibilitaron sostener económicamente este proceso. Dejó de ser meramente autosustentable - una situación en la que "si no ganás, al menos no perdés" o "todo lo que entra sale", como me planteaban al comienzo- y empezó a dar ciertas ganancias. Con una parte de los excedentes de dinero el sello compró equipamiento para alquilar, no sólo sonoro sino también un proyector. Estos equipos quedaron a cargo de Cristóbal, responsable de gestionarlos entre las fechas de las bandas y los alquileres a particulares, tarea por la que acordaron que recibiera una comisión.

En cuanto a la formalización legal, desde que empecé el trabajo de campo los miembros del sello se relacionaban con un joven abogado, Guillermo. Interesados en capacitarse en cuestiones de licencias y derechos de propiedad intelectual, entre los años 2010 y 2011, organizaron algunas charlas públicas sobre esas cuestiones invitándolo como disertante. Pero no eran las licencias un problema al interior del sello ${ }^{132}$, sino las relaciones económicas entre el sello y las bandas. Al referir a la situación previa a la firma de contratos, Ángel recordaba: "Los discos eran un problema... ¿¿de quién son los discos? (...) ¿a quién se los diste? ¿Para qué se los diste? ¿Les gusta? ¿Los va a escuchar?’, qué sé yo (...) El disco era un lugar clave de que no estaba claro el acuerdo, de quién era el disco. La plata que generaba el disco. Los bookings, tipo, generar una fecha, no sé, ¿cuánto es? ¿El 30? ¿El 20? ¿El 10? ¿El 15? (...). Lo que fue empezando a ordenar eso fue cuando hicimos un acuerdo con Believe para subir la música a las plataformas de streaming (...). Entonces ahí ya dijimos, 'ah, bueno, le decimos a los músicos que tanto, tanto, tanto, tanto', y ahí empezó a ordenar, ¿viste?”. De esta manera, fue la necesidad de realizar un contrato

\footnotetext{
${ }^{132}$ A lo largo de su trayectoria el sello había usado tanto las licencias Creative Commons como el sistema comercial de copyrigth. El primero es un sistema colaborativo y de licenciamiento de ciertos derechos que surge al calor de los cambios que las nuevas tecnologías han introducido en las formas de editar, difundir y consumir música, mientras el segundo es una modalidad donde todos los derechos son reservados (Navarro 2015: 156). Los integrantes del sello defendían, frente a posturas principistas, la convivencia entra ambos sistemas.
} 
con una distribuidora digital lo que impulsó la realización de contratos entre el sello y las bandas.

Como me enteré a lo largo de dos reuniones de enero y febrero de 2014 donde participaron Ángel, Nicolás, Anache, Cristóbal y también Shaman, Edu de Los Pilares y Mariano de Los Polares, a partir del acuerdo digital cada banda y el sello "dejan de preocuparse por controlar, por poder cobrar por el tráfico y la venta en esos sitios”. Tal como explicaba para todos los presentes Ángel, esta empresa brinda el servicio por un porcentaje. Más que nada, lo que les interesaba a ellos, era "ser distribuidos y llegar a más gente, no la guita que deja", es decir: "la distribución por la distribución”, "más que por lo económico, por el impacto". Luego, Ángel dio ejemplos de lo irrisorio de los valores que se pagan. Nicolás agregó que "igual Believe monetiza mucho en Youtube" y que "no era exclusivo", es decir, que todo lo que se hace por fuera de las plataformas que Believe maneja “es cosa y negocio de uno". Ninguno de los participantes, ni siquiera yo, desconocía totalmente este proyecto y las líneas generales del funcionamiento de Believe, ya que la reunión era precedida de conversaciones entre unos y otros.

Movilizados por el acuerdo que harían con la agregadora digital, pero también por los conflictos latentes por la falta de claridad en las relaciones económicas entre las partes, en las reuniones de sello se decidió que era necesario realizar los contratos. A fines del año 2013, algunos miembros del sello empezaron a conversar un acuerdo con Guillermo para regularizar todos los aspectos de propiedad intelectual de las bandas catalogadas, necesario para poder firmar un contrato con una agregadora digital. Guillermo elaboró estos contratos, específicos para cada proyecto musical, los cuales fueron firmados a mediados del año 2014, como expuse al principio de esta tesis. Se definió que Guillermo pasaría un presupuesto $^{133}$ y haría el trabajo para todas las bandas, si bien a principios del año 2014 se estableció finalmente un acuerdo mayor. Guillermo se convirtió en el "representante legal" del sello y en el encargado de realizar los registros y el seguimiento de todas las bandas, a la vez que ofrecer su asesoramiento permanente a ellas. Se estableció que los costos del

\footnotetext{
${ }^{133}$ En una forma típica de vinculación económica en estos mundos musicales emergentes, los valores del presupuesto eran menores al de su valor de mercado, a la vez que Guillermo tejía nuevas relaciones para desarrollar su actividad profesional, a partir de los vínculos del sello con instancias estatales. Avanzado el trabajo de campo fue contratado como capacitador para Recalculando.
} 
servicio serían pagados por el conjunto de los artistas, en porcentajes correspondientes a su ganancia, situación posible por el fortalecimiento económico del sello.

$\mathrm{Al}$ establecer los ingresos porcentuales de las partes implicadas en cada una de sus actividades conjuntas -arreglos distintos para cada proyecto musical-, se regularizaron también las entradas monetarias del sello. Este esquema se alejaba de las prácticas de los sellos con los que compartían escena para acercarlos a compañías discográficas que tienen décadas de trayectoria y son analizadas por la bibliografía ya citada como pequeñas empresas. ¿Es que Concepto Cero se había transformado en un proyecto empresarial? Sin duda no era tampoco -al término del trabajo etnográfico- una "empresa discográfica" en los términos que fueron expuestos en el capítulo II, ya que sus actividades excedían con mucho la producción de discos y no respondían al tipo de estructura de estos sellos. Ahora bien: no es el sello discográfico la única manera en que actualmente se diseñan y ejecutan empresas dedicadas a la música. $\mathrm{Y}$ en este sentido, léxico, aspiraciones y prácticas asociadas por los miembros del sello a las empresas se podían encontrar en Concepto Cero.

En cuanto al primer punto, durante el período de campo pude conocer de primera mano varios emprendimientos alrededor de la música como productoras de contenidos web para bandas, plataformas de distribución y difusión web para artistas, entre otras. Me sorprendió en algunos casos la forma en que sus dueños las presentaban. En una capacitación de Recalculando dedicada a las técnicas de streaming, Seba de Vivo Conectado - un sitio de transmisión de recitales online- se posicionaba como parte de una empresa que competía en ese mercado con otras, al mismo tiempo que como un fan de la música que veía en este emprendimiento una manera de desarrollar el famoso Do-ItYourself (Hazlo tú mismo), una idea-fuerza para la tradición independiente que se retrotrae por lo menos a la primera ola del punk (Dale 2009). Además de explicar cómo hacer un streaming doméstico, Seba publicitaba de alguna manera su servicio para recitales a la escala de la escena y explicaba: "La idea es generar monetización a partir de las visitas de los videos", ya que "la gente representa plata", que se puede utilizar "para pagar flyers, para comprar cuerdas o lo que sea... esto es lo de hacerlo tú mismo". Este episodio era uno entre tantos que mostraba la mayor legitimidad que las categorías de empresa -asociadas a la escala micro y el auto-empleo-adquirían entre las redes de Concepto Cero. 
En cuanto al segundo punto, Nicolás me había transmitido desde el primer día un deseo para Concepto Cero: no sólo "hacer algo que esté bueno", "aprender" y "pasarla bien" sino también "trabajar como una empresa". En ese momento, el carácter “empresarial” que Nicolás ya anunciaba como deseable para el sello durante el año 2011, resultaba difícil de digerir para Matías que, como ya se señaló, terminó por abandonar el sello. A pesar de que Matías buscara ganar dinero y en última instancia, "vivir de la música", en varias ocasiones dejaba entrever su rechazo al cumplimiento de ese objetivo a partir de un perfil empresarial. Si bien el sello se vinculaba prácticamente desde los inicios con distintas pequeñas empresas locales, como la cerveza Cabra 52 y el hostel Frankville, la relación se presentaba de amistad en los términos del grupo, al punto que Pachi, el dueño del hostel, los invitaba a su fiesta de cumpleaños. Por el contrario, la figura del empresario resultaba reactiva para Matías. Frente al fanatismo por Steve Jobs que todos adjudicábamos a Nicolás, quien tenía entre sus libros su biografía autorizada y era un comprador regular de productos Apple, Matías decía pocos días después de su fallecimiento: "Yo no me banco el fanatismo por Steve Jobs, que sería un genio pero al fin y al cabo era un empresario".

Pero Nicolás mantuvo esta idea durante todo el período: en una reunión en el verano del año 2014 con dos personas de prensa, les planteó querer "salir del ghetto... que el sello se vea como un sello, como una empresa y no como un grupo de amigos...". El trayecto recorrido en estas páginas nos da una idea de que habían avanzado en esta aspiración en un doble sentido: tomar responsabilidad en varias áreas de la producción y la gestión de música que antes les resultaban ajenas, y volver la toma de decisiones menos horizontal que en sus comienzos. El proceso de profesionalización que expongo en este capítulo especializa y redefine los vínculos de los amigos entre sí y con la música. El sello seguía siendo una red de amigos y pares, pero Ángel y Nicolás la veían en transición hacia una forma nueva. En el año 2015, Ángel me decía: "A mí me parece que nosotros lo que hicimos ahora fue salir, salir de ese mundo de los sellos que la gente llama de gestión colectiva, y fuimos a otro lugar que es más como, puede ser sellos como Estamos Felices, Acqua Records, Los Años Luz, que son PyMES culturales...”. Ángel matizaba que el emprendimiento se percibía todavía pequeño en comparación con esos sellos pero definitivamente alejado de "un sello de hobby, o de amor, o de, no sé, de que el tiempo que te queda lo dedicás a eso". 
Como había ocurrido al interior de Concepto Cero, no todos los músicos y gestores de la escena asociaban necesariamente la profesionalización con la noción de empresa y mucho menos a sus personas como "empresarias". En una ocasión, con Diego de Desde el Mar, comentábamos la existencia de otros sellos marplatenses: él mencionó a Pistilo Records y yo a Casa del Puente Discos. Él replicó “....pero Casa del Puente es otra cosa. Es Pedro poniendo plata y editando discos, o sea, no es la misma movida que puede ser Pistilo, que puede ser Desde el Mar (...) Cómo lo llevan adelante, ¿no?”. Interpreté: “Es otra manera de trabajar", y él me contestó: "Más empresa, sí." En Desde el Mar compartían la idea de un crecimiento y profesionalización desde una red horizontal de amigos a la que veían en contradicción con la empresa. Por el contrario, Nicolás, Ángel y otros miembros del sello que se inspiraban en la idea de una "empresa" - o como decía quizás con mayor precisión Ángel: de una "pyme”- pensaban que la profesionalización se beneficiaba de estructuras más diferenciadas y pulidas.

A lo largo de este apartado pudimos apreciar los cruces, en las prácticas de Concepto Cero, de dos aspectos hasta hace muy poco considerados dicotómicos: la creatividad y el profesionalismo. Como han planteado Boltanski y Chiapello (2002), a partir de la década de los 70 el capitalismo entró en una lógica de incorporación de ciertos elementos que las prácticas artísticas colocaban en el eje de su crítica al capital: su inautenticidad, su falta de apreciación de la belleza, sus límites a la creatividad y la libertad. Actualmente, esta oposición, correspondiente a la bifurcación tanto real como imaginaria entre los mundos artístico/expresivo y el regido por la lógica del negocio, se halla desbordada y comienza a cambiar su forma (Semán 2015). En particular, entre los jóvenes, la bifurcación entre lo creativo y lo empresarial está re-semantizándose, tal como señalan Mendes de Almeida y Machado Pais (2012) para el caso de Brasil. Estos analistas observan en los grandes centros urbanos de ese país la visibilidad y crecimiento de la figura de los jóvenes emprendedores. Esta ya no se asocia automáticamente a los jóvenes empresarios o ejecutivos sino que abarca una red de jóvenes músicos, poetas, escritores, actores, cineastas, entre otros. En estos perfiles los valores de la competencia, la profesionalidad, la experiencia y el rendimiento se encuentran con los de la creatividad, la expresividad y el placer. 


\section{"Armar un equipo"}

En el transcurso de mi investigación, al interior de la organización del sello los roles se fueron fijando: en principio para cada evento o proyecto, luego, estos patrones comenzaron a repetirse para los diferentes proyectos. Como desarrollé a partir del caso "Los Ellos", en los primeros años del sello la división del trabajo era más bien débil, si bien había algunas orientaciones específicas vinculadas a la formación específica que cada uno tenía y al compromiso que depositaba en el sello. En los años siguientes, en un contexto de adscripciones estéticas múltiples y donde para los sellos de la ciudad seguía siendo común que "todos hagan todo", en Concepto Cero se produjo una decantación. Quienes ya transitaban sus redes empezaron a dividir entre sí el trabajo, mientras, en sintonía con esta situación, el sello empezó a buscar activamente entre los amigos a personas específicas para actividades también específicas.

A fines del año 2012 tuvimos una reunión de balance Ángel, Nicolás, Cristóbal y yo en la casa de Cristo: los dos primeros, con la dirección de Nicolás, se estaban encargando de la gestión y comunicación del sello, mientras Cristo realizaba principalmente tareas de producción. Junto al Pampa en diseño gráfico y Anache en otras tareas de gestión constituían en ese momento el staff estable del sello, además de colaboradores como Cata, Tadeo y otros que aún orbitaban a su alrededor. En dicha reunión, Ángel daba cuenta de que "los recursos humanos me preocupan", mientras Nicolás especificaba que "necesitamos una o dos personas en producción" y "una persona que labure las redes sociales del sello, ya tengo los huevos...”. Ángel decía que a las personas que hicieran redes sociales habría que pagarles, mientras para Nicolás era deseable "buscar a alguien que le sirva esto para laburar, para formarse", de modo de incluirlo en el grupo de trabajo del sello y no tener que involucrar gastos fijos.

En la búsqueda de estos objetivos, Javier entró poco tiempo después como VJ y diseñador, luego de ser invitado a responsabilizarse de las visuales de varios eventos, especialmente de Sonido Expansivo. Luego, a inicios del año 2013 y por intermedio de Cristóbal se incorporaron Mileth, Amparo y Gastón. Mileth, una joven estudiante de la Facultad de Bellas Artes, se sumó para encargarse de las actualizaciones y del contacto en la página de Facebook de Concepto Cero. La "community manager" también colaboraba 
durante los eventos en tareas que muchas veces también yo ${ }^{134}$ realizaba, como la taquilla. Amparo, estudiante de artes audiovisuales, se sumó a colaborar en la cobertura de fotografía y video para los eventos, al igual que Gastón, quien había sido compañero de Cristóbal en la carrera de cine. Él explicaba que tomaba fotos sólo cuando Cata no podía. Nicolás le había dicho que "estaban buscando tener producción audiovisual porque fotógrafos ya había" así que él procuraba filmar más que nada. A fines del año 2013, Federico, un músico que Nicolás y Cristóbal conocieron en el estudio de Matías, se sumó a Cristóbal en las actividades de producción, también para relevarlo cuando este regresara por razones personales a vivir a Tucumán, a mediados de abril del 2014.

Esta fue una de las cristalizaciones de la división del trabajo al interior del sello que, más allá de ciertos cambios con el correr del tiempo, se encontraba en todo caso bastante lejana de la "organización desorganizada" de amigos que producen música juntos (Boix 2013) que afirmé en su momento para los sellos musicales emergentes de La Plata. Esta especialización relativa de las tareas les permitió, desde su perspectiva, planificar y llevar a cabo de la manera más "profesional" posible lanzamientos de discos, cronogramas de "fechas" y eventos, estrategias de publicidad y prensa, etc. Especialmente, en una característica que confirmaba para ellos mismos y exteriorizaba para los demás su profesionalismo, produjeron exitosa y cada vez más ajustadamente eventos para terceros ${ }^{135}$, a la vez que se interesaban en obtener su financiamiento -bajo la forma de sponsors, por ejemplo. Como planteaba Cristo, trabajar con este tipo de actores implicaba una “organización interna bastante pulida". Cabe notar que, de acuerdo a cálculos propios del sello a los que tengo acceso, a partir del 2013 la producción de eventos para terceros, tanto del sector público como privado, creció de forma notable y fue la categoría que generó más ingresos.

A pesar de la mayor organización y especialización de las tareas en comparación al momento inicial del trabajo de campo, todas estas personas no dejaron de realizar muchas otras actividades más allá de su tarea principal: de la misma manera que en un recital

\footnotetext{
${ }^{134}$ Justamente, como vimos en el capítulo anterior, este proceso de especialización se percibió incluso en el trato hacia mí, ya que me empezaron a interpelar en tanto "socióloga" e "investigadora" que podría darles pistas para conceptualizar sus prácticas y para entender los cambios en la industria.

${ }^{135}$ Como vimos en el capítulo II, el sello venía trabajando con Fesaalp en La Plata y el congreso de diseño gráfico Trimarchi Dg en Mar del Plata. Entre los eventos más relevantes, en 2013 produjeron la fiesta de cierre del Congreso Internacional de Creative Commons en la ciudad de Buenos Aires
} 
multitudinario me podía encontrar a Cristo y Nicolás en plena distribución de folletos para una fiesta del sello, Javier y Mileth participaban de las definiciones conceptuales de los cinco años de Concepto Cero. No obstante, ya para mediados del año 2014 Mileth, Gastón y Amparo no participaban plenamente del sello pero sí, tal como había pasado antes en los casos de Mariano, Tadeo y Melina, continuaban su tránsito por la escena y su involucramiento con otros proyectos independientes locales. En este sentido reflexionaba Ángel: "Una cosa que siempre le costó [al sello] fue armar un equipo sólido para laburar". La clave al respecto radicaba en que "la gente tiene que coparse" ya que los beneficios económicos tardaban en llegar o no eran todavía importantes. "Coparse" implicaba comulgar con el modo de trabajo que proponía el sello, que para algunos resultaba poco "relajado" y demasiado "serio". A diferencia de otros sellos de La Plata con los que interactué que organizaban con todo dos reuniones por mes, en Concepto Cero la regularidad era como mínimo semanal, además de todo el trabajo que se adelantaba semana a semana vía Internet ${ }^{136}$. Este modo de trabajo no siempre encontró pares entre los artistas musicales y, en este sentido, el sello se vio involucrado en conflictos e incluso rupturas con algunas bandas con las que trabajaba. En un festival, Nicolás y Cristóbal tuvieron que perseguir a los distintos músicos de una banda y apurar a los que llegaban tarde, cosa que luego le reprocharon. En una fiesta, Nicolás me comentó irritado que una banda invitada había tocado más tiempo del escrupulosamente indicado, arruinando el cronograma.

La dificultad para "armar un equipo", no obstante, no era exclusiva de Concepto Cero y la pude observar de primera mano en otros sellos de La Plata con los que Concepto Cero entró en relaciones: en las reuniones de TICA, los responsables de otros sellos se quejaban de que sus compañeros no aparecían. También resultaba difícil llevar a cabo los proyectos y mantenerlos en el tiempo, de lo que el progresivo apagado de TICA es una muestra. De la misma manera, en Concepto Cero vi caer tantos proyectos como realizarse otros, y registré conversaciones enteras sobre proyectos nunca realizados: "subdominios" de la página web para que los artistas visuales expusieran sus trabajos, un "sub-sello de noise y música experimental" -propuesto por el Tata-, una "plataforma web" para todas las

\footnotetext{
${ }^{136}$ La exigencia era percibida por mí misma, ya que en varias ocasiones aunque quisiera no podía cubrir etnográficamente la totalidad de eventos a los que se me invitaba. La sensación de estar abrumada por la cantidad de temas que se discutían en las reuniones, que pensaba propia del momento inicial de la investigación, se mantuvo durante todo el período.
} 
bandas de la ciudad, un recital del sello en Tecnópolis a plasmarse en un DVD, una producción entre musical y teatral en la Casa Curuchet, entre otros. Sin embargo, la inestabilidad y el carácter efímero del grupo y de algunos proyectos en el caso de Concepto Cero no impidieron, por un lado, la identificación con una institución musical durante más de cinco años ${ }^{137}$, por el otro lado la acumulación de saberes, herramientas y recursos, para un proceso de profesionalización de las trayectorias de los integrantes que persistían entre sus redes, como desarrollo en los próximos apartados.

\section{"Trabajar en" y "vivir de la música"}

Suele decirse que la escena de La Plata es la de trabajadores del Estado que habilitados por unos buenos horarios laborales pueden dedicarse el resto del día al rock. En mi investigación realizada entre 2009 y 2011 sobre un sello de música indie, encontré una situación que avalaba en parte esta imagen: los músicos entrevistados en aquel momento, muchos de ellos integrantes de bandas exitosas en términos de la escena, consideraban "trabajo" al realizado fuera de la música, remunerado pero no necesariamente bajo un régimen de salario regular. Muchos trabajaban en relación de dependencia con organismos públicos, como la Municipalidad, los ministerios provinciales, la Universidad, aunque también con empresas privadas. En otra serie de casos, el trabajo aparecía vinculado de alguna manera a la música y el arte a partir de la propiedad de salas de ensayo y/o estudios de grabación, dictado de clases de música, trabajos freelance de diseño gráfico, dibujo, diseño de indumentaria y de objetos, etc. Lo novedoso es que en ambos casos la música no era simplemente un "hobby": lo que observaba era una complementación entre trayectorias en la música y otras actividades como una posibilidad relativamente nueva (apuntada por Semán 2011) que estos músicos explotaban de manera ejemplar. Sin embargo, a pesar de no ser un simple momento de ocio, las actividades musicales se desvinculaban relativamente de la obtención de medios de vida. Estos músicos decían que no es que no pretendieran "ganar algo de plata", pero que no podían aspirar a "vivir de la música", en el sentido de vivir de tocar y de vender discos.

\footnotetext{
${ }^{137}$ Hay sellos musicales que en La Plata tienen esta cantidad de años o incluso más: Laptra cumplió en 2014 10 años de funcionamiento.
} 
En el caso de los integrantes de Concepto Cero, partícipes de una generación posterior de artistas de La Plata, la relación entre la música y el trabajo se planteó desde un comienzo de modo diferente: cuando comencé la investigación todos sus miembros estables eran aún estudiantes universitarios, vivían con sus padres si eran platenses, y si habían venido del "interior" recibían ayuda económica para alquilar un departamento y sustentar el día a día. Algunos combinaban sus obligaciones estudiantiles con trabajos en el mundo de la música y del arte, si bien esas actividades no alcanzaban para su sostén económico, ni pretendían por entonces que así fuera: Nicolás, como community manager y organizador de eventos, Matías en su rol de técnico de grabación del estudio que había montado en su casa y Tadeo, a partir de la confección de flyers y otras piezas gráficas para bandas. Por lo demás, se las rebuscaban para obtener recursos: en el 2011, Matías vendía dulces caseros junto a su novia durante las reuniones del sello; al año siguiente, en el ciclo del hostel, el Pampa vendía porciones de torta de lemon pie y de tarta de chocolate: "tenemos un microemprendimiento" me dijo, explicitando que su novia cocinaba y él se encargaba del diseño de la tarjeta de promoción y de las ventas. Como muchos otros jóvenes de La Plata, los de Concepto Cero se encontraban transitando la experiencia de aprender a vivir sin la protección familiar directa, un camino en el que tanto afectiva como económicamente dependían mucho más de los amigos y de los compañeros. La circulación de favores y de préstamos entre ellos, que en estos casos sustituyen con mucha ventaja al dinero, es una situación que se repite típicamente en las redes estudiantiles de La Plata.

Las trayectorias posteriores de Cristóbal, Nicolás y Matías nos muestran cómo se abrían en este mundo estético posibilidades de trabajo donde lo que se complementa ya no es "la música" con "el trabajo" - entendido como algo que sucede fuera de ella-, sino distintas actividades remuneradas alrededor de la música. A continuación, reconstruiré los casos de Cristóbal, Nicolás y Matías, cuyos vínculos singulares con la música resultan estructurantes a fin de analizar el tipo de profesionalidades emergentes que se abren para estas nuevas generaciones de artistas. El caso de Cristo, más orientado a la producción y gestión de eventos, el de Nicolás, más vinculado a la gestión y a la asesoría, y el de Matías, más relacionado a la producción discográfica, son alternativas profesionales novedosas que me mostró Concepto Cero y a las que podíamos asistir en otros espacios de la llamada 
escena platense que guardaban cierta afinidad con ellos, como sellos emergentes, festivales de música, casas culturales, productoras, etc.

\section{Cristóbal}

Al principio del trabajo etnográfico era común para mí llegar a las fechas del hostel y encontrármelo a Cristo en la puerta, que no me dejaba entrar gratis sólo a mí sino también a quien ocasionalmente me acompañara, a pesar de mis pedidos en contra. Si bien en estos comienzos Matías y Nicolás podían comentarle en broma en una reunión que "ya se les había ocurrido una manera de hacerlo trabajar, que le iban a conectar al celular una descarga pequeña", Cristo terminó implicándose con compromiso en las tareas de producción de "Los Ellos". Al año siguiente, tuvo una participación similar en las fiestas de aniversario del sello, entre otros eventos. Poco a poco, Cristóbal fue desplazándose de producir algunos eventos a convertirse en el "productor" del sello y de otras iniciativas en las que el sello se implicaba, como los recitales de Sonido Expansivo, en los que comenzó a cobrar por realizar su trabajo. Ya en el año 2012, en los eventos musicales siempre podía verlo ocupado en distintas actividades técnicas, especialmente comandar el armado del escenario, la ubicación y cableado de los distintos equipos, sumado a que eventualmente solía cooperar en la mesa de controles de sonido. Entretanto, trabajaba en la organización de fiestas de otros amigos como las chicas de Tormenta. Dada su experiencia y su vínculo con el Cuchi y JP, también comenzó a trabajar para Ciudad Alterna en tareas de producción, luego de lo cual fue convocado para trabajar en el festival Arte Joven ${ }^{138}$, dependiente de la Municipalidad de La Plata.

Él mismo me narraba su trayectoria al interior del sello, de la siguiente manera: “...empecé sin una tarea definida y hacía como más la parte de... las tareas por ahí que son más chotas (...) como estar en una taquilla. Lo sigo haciendo, no tengo drama, eh. Después, la pre producción y todo eso también, siempre me interesó y como tiene una relación con el cine... lugares, sonidos, luces... quién va a estar en la taquilla, todos los detalles para que salga bien, horarios, coordinar las bandas para los equipos, todo... la parte chota de la

${ }^{138}$ Promocionado por el municipio local como un ejemplo de gestión cultural exitosa. Su primera edición data de 1996 pero experimenta en el período de investigación una expansión que le otorga a partir de 2010 el estatuto de festival, proceso de crecimiento en el que se involucra más fuertemente con el mundo de arte musical emergente de la ciudad -especialmente con los sellos musicales platenses. 
música (risas)". Esta parte "chota"139, sin embargo, adquiría una importancia clave al interior del grupo: frente a los cronogramas armados por Nicolás para el montaje de una fecha, Cristo era quien decía "este tiempo no nos alcanza" o "sí o sí tenemos que armar la bata [la batería] antes". En consonancia con ello, Cristóbal valorizaba su saber de forma relacional: "Nicolás no maneja tanto eso, como que no sabe mucho eso...", y graficaba: "No le des para guardar un instrumento a Nicolás porque lo guarda al revés (risas)". Efectivamente, yo no con contaba con registros etnográficos de Nicolás armando un escenario o manejando una consola: de dichos enseres siempre se ocupaba Cristo y, en su momento, Matías.

También Cristo relataba el hecho de haber ido "aprendiendo otras cosas más de gestión... y todas esas cosas que hace Nico que también me caben, digamos...”. En ese plan había viajado a algunos encuentros provinciales pre MICA con Lautaro y Nicolás. Sin embargo, era muy raro encontrárselo en un taller de formación más allá de Recalculando: lo de él era "todo práctica" o a veces "ni siquiera práctica, a veces, como que me cuentan cómo hicieron y "ah, mirá, lo voy a hacer". Al término de su participación en el sello por causa de su regreso a Tucumán, Cristo era reconocido por la producción también por el resto. Gastón, uno de sus amigos que luego ingresaría al sello, decía que Cristo "la tiene re clara" en la producción y que, en ese sentido, era "la mano derecha de Nico". En una entrevista pública, Nicolás decía que Cristo "tiene un rol más de productor, de ir a lo duro, todo lo que supone la producción de eventos. Él está prácticamente desde el comienzo del sello y fue ganando un lugar como todos, que en realidad arrancamos prácticamente sin saber nada o muy poco" 140 .

\footnotetext{
${ }^{139}$ La producción era un problema para Concepto Cero, quizás no sólo por resultar la parte "chota" o "piedra" de la música para varios de los miembros del sello, sino porque era la menos visible. Es notable que Concepto Cero siempre buscó productores, mientras nunca le faltaron fotógrafos, videastas y diseñadores. Hacer flyers, fotos o videos para el sello podría no obtener una retribución económica directa pero los materiales producidos eran publicados en redes sociales virtuales y multiplicados en cada clic. La visibilidad obtenida otorgaba prestigio personal en un mundo de oferta audiovisual sobresaturada, además de que podría redundar en la obtención de trabajos pagos, como de hecho les había sucedido a algunos fotógrafos y diseñadores que habían pasado por el sello.

${ }^{140}$ Uno habla de sello y es un comodín para decir un montón de cosas". Entrevista a Nicolás Madoery, Concepto Cero. Sin fecha, publicado en: http://www.elserviciopostal.com.ar/entrevistas/nicolasmadoery.html\#.UXApM6JLPrm (consultado: jueves 18 de abril de 2013)
} 


\section{Nicolás}

Como fue señalado en el capítulo II Nicolás había trabajado en algunos boliches de la CABA en actividades muy elementales de gestión, a las que él refería con la expresión “che pibe". A lo largo del período estudiado, Nicolás continuó su desempeño en diversos trabajos temporarios de gestión relacionados con la música y el arte: en el año 2011 hizo la comunicación en las redes sociales Facebook y Twitter del Trimarchi DG, donde contaba que le pagaban por hora: "Abro el Facebook [institucional del evento] y se me pone a hablar todo el mundo... es un trabajo muy intenso", decía por entonces. También se encargaba de hacer algunos trámites "de onda” en La Plata, ya que los organizadores vivían en Mar del Plata. No era la primera vez que trabajaba para estos amigos: ya había ejercido como acompañante de los invitados internacionales del evento, un puesto para el que se requería ser bilingüe: "Yo dije que era bilingüe, más o menos la piloteé", le comentaba a Melina con motivo de convencerla de que se anotara para ser seleccionada en ese trabajo. Durante los dos años siguientes trabajaría en la coordinación y producción de shows y fiestas realizadas durante el congreso. A principios del año 2012, me contó que había empezado a trabajar para el FIFBA -Festival Internacional de Folklore de Buenos Aires, luego Festival del Bosque-, según me dijo "de forma gratuita". Se había implicado en la organización de la sección "off" de "shows fuera del bosque", una serie de conciertos de artistas asociados a una vertiente rockera de la música popular, donde entre otros tocarían Tata Laxague, y Shaman y los Pilares de la Creación. A mediados de ese mismo año comenzó a coordinar los shows del ciclo Sonido Expansivo en el Senado de la Provincia de Buenos Aires y a trabajar para Recalculando. Mientras en el primer caso se trataba básicamente de organizar shows, como parte del equipo de Recalculando realizaba tareas

de capacitación y asesorías en aspectos de gestión, industria y producción musical, entre otras acciones dirigidas a músicos, emprendedores musicales y sellos de gestión colectiva. Este último trabajo le exigía viajar por las distintas provincias del país para asistir a jornadas de trabajo, talleres y conferencias.

Desde el inicio del trabajo etnográfico Nicolás había desplegado su interés por la formación profesional, específicamente en la gestión de la música. Durante la entrevista en la que lo conocí personalmente, en el año 2010, me contó: “...estudié en varios lados: en 
Capital en Recursos Culturales ${ }^{141}$ (...) seminarios así de gestión cultural, básicamente, financiación de proyectos, o gestión de proyectos. Después hice un seminario que dio la UMI, ahora hice un seminario para emprendedores que dio la cámara de empresas de la provincia”. En continuidad con este interés, apenas comencé el trabajo etnográfico, lo vi asistir a cursos y talleres del Instituto Cultural y estar atento a iniciativas de capacitación similares, como las del incipiente Recalculando. Siempre informado de las oportunidades de formación, en el verano del 2014 me invitó a acompañarlo en la realización de un curso online: "Introduction to the Music Business", dictado por un manager norteamericano en la plataforma web de la Berklee College of Music ${ }^{142}$. Durante el período que duró el curso nos reuníamos varias veces por semana a ver videos tutoriales y realizar ejercicios de multiple choice sobre la historia de la industria de la música y su formato actual, la lógica de los contratos de grabación, los conceptos básicos sobre licencias, la dinámica del mercado de la música en vivo, entre los temas más relevantes.

También fue señalado en el capítulo anterior: Nicolás era un lector asiduo de publicaciones sobre el mundo de la música. Asimismo, desde que empezó a trabajar en Recalculando, se interesaba también por los libros y encuestas que publicaba el Ministerio de Cultura de la Nación. No sólo comentaba estos materiales de lectura entre sus amigos, sino que hacía una cuidadosa presentación de ellos en su cuenta de Instagram, donde otros usuarios además de "likear" le preguntaban qué le habían parecido, le recomendaban otros textos o le prometían préstamos. Esta presentación cooperaba en mostrar a Nicolás como un experto en gestión musical para muchos participantes de la escena. Así, en ocasión de una charla de TICA en Ciudad Alterna, un grupo de productores conocidos por traer bandas de cumbia peruana y colombiana a La Plata contaron que lo habían contactado al inicio de esa iniciativa "para que nos explicara cuánto valía y cómo se hacía para traer una banda de afuera”.

${ }^{141}$ Refiere a recursosculturales.com, "un proyecto cultural independiente con sede en la ciudad de Buenos Aires", que ofrece "información, herramientas, contenidos y servicios para artistas, emprendedores, gestores y organizaciones del arte y la cultura" (consultado: 15/01/2016).

${ }^{142}$ Una universidad privada norteamericana de música, con fama de ser la más grande del mundo. 


\section{Matías}

El caso de Matías, del que no pude realizar un seguimiento en profundidad por su alejamiento temprano del sello, es representativo de una posibilidad que se expande en este mundo estético en los últimos años. Ya en su propia habitación habilitada como estudio, al que llamaba "La pieza", produjo otros álbumes más allá del propio. Cuando a fines del año 2011 se mudó a otro pH en la zona del Parque Castelli, armó un estudio más sofisticado en la misma vivienda al que llamó "El zumbido". En este nuevo estudio, la sala de grabación en el argot: "pecera"- se encontraba separada de la sala de controles, ambas debidamente isonorizadas. Cuando a fines del año 2012 fui a visitar este nuevo estudio me mostró y explicó orgulloso cómo la sala estaba acustizada y decorada. Además me hizo escuchar lo que estaba mezclando en ese momento, unos materiales de la banda Cinemática, donde tocaba un primo de Cristóbal. El estudio tenía una página de Facebook y un blog, con fotos de la sala y otras de los equipos, acompañados de especificaciones técnicas. Además, a la página subía las distintas producciones terminadas con audios y fotos. Los gastos de alquiler los compartía con Cristóbal, que tenía su habitación en otra parte del pH, aunque me aclaraba que su amigo naturalmente pagaba mucho menos. Le pregunté: “¿Pero si te vas de acá, ¿qué pasa con la sala?”; para mi sorpresa, explicó que todo era desmontable. De hecho, cuando Cristo se volvió a Tucumán, Matías volvió a mudarse del llamado casco urbano de La Plata para instalarse en Villa Elisa ${ }^{143}$.

A partir de estos casos podemos notar cómo se obtienen posiciones más sólidas a lo largo de la escena a partir del establecimiento de contactos y trabajos. Es verdad que se trata de contratos temporarios -en palabras de Cristo: "Laburo pero no tengo un laburo fijo..."-, y en esto los datos etnográficos acuerdan con los análisis que enfatizan el carácter de trabajo por proyecto de los emprendimientos culturales contemporáneos, entendido como la participación en emprendimientos puntuales. García Canclini (2012) en un estudio sobre prácticas emergentes en las artes visuales, las editoriales y la música en México y España realiza una crítica de esta modalidad por proyectos, en tanto conlleva una fuerte

\footnotetext{
${ }^{143}$ Una localidad en el límite del partido de La Plata, camino hacia la CABA.
} 
informalidad y precarización laboral. Para Canclini esto sucede al interior de una configuración social que ya no puede asegurar la estabilidad en líneas generales y no sólo en relación con la música. Aún más: la disminución de las "ventajas comparativas" de las carreras tradicionales y del trabajo asalariado en un escenario en el que se debilitan las garantías de permanencia laboral puede hacer orientar a los jóvenes a opciones profesionales alternativas, tal como sugiere Infantino (2011: 152) en un estudio sobre los artistas de circo de la ciudad de Buenos Aires.

En el caso aquí estudiado, las experiencias laborales no por ser puntuales dejan de acumularse en un trayecto que empieza a tener una orientación y un sentido vital para sus protagonistas. En las trayectorias descritas, los trabajos vinculados al sello enriquecen el currículum profesional; además, la multiplicación y combinación de trabajos pagos permiten una independencia económica en relación con los padres: "me están dejando de mantener...", me decía Cristo el año que empezó a trabajar en Sonido Expansivo y los otros eventos mencionados, mientras Nicolás comenzaba a planear su mudanza desde la casa de su madre hacia un departamento alquilado con su propio dinero, concretada al año siguiente. Por lo demás, los contratos laborales temporales que Nicolás y Cristóbal obtuvieron en el Estado quizás eran los primeros que habían alcanzado en su relación con el mercado de trabajo, incluso cuando tenían que combinarse con otros ingresos para ser sostenibles económicamente.

En este contexto transformado también cambia la noción de "vivir de la música" como sinónimo de originar recursos a partir de la obra musical que permitan acceder totalmente a medios de vida. Esta imagen es en gran parte deudora de una noción de la profesión y de la carrera concebida desde la industria discográfica. Por el contrario, mis interlocutores en el sello musical ya tenían claro que "vivir de la música" no se podía entender desde las ideas de vivir de una obra ni de una banda... ¿Pero exactamente cómo había que comprenderlo? Al comienzo de la investigación, Nicolás me decía: "Yo pienso que se puede [vivir de la música], pero no sé cómo... De una banda no vas a vivir. Pero hay un montón de cosas alrededor, como puede ser la publicidad, la tele, el cine... que teniendo todo un equipo trabajando...", proyectaba. En consonancia con estas palabras, el sello se involucró durante el período en varios intentos, muchos de ellos infructuosos, que produjeran dinero: desde la venta de remeras, postales y otros objetos relacionados con la 
música, hasta la producción de eventos y fiestas, booking para otras bandas y trabajos editoriales para artistas de otros sellos. Acompañar estas iniciativas me mostró que todo el tiempo se ensayaban formas nuevas para alcanzar la meta de "vivir de la música". Los términos actuales de esta aspiración aún permanecen inciertos y, en este sentido, Ángel me señalaba: "Mi proyección con el sello es la misma proyección que tenés como músico, como que tiene el 98\% de los músicos, que es: (...) yo quiero vivir de esto. Eso, ese camino para vivir de eso... no sabés lo que es".

Esta incertidumbre es analizada por García Canclini (2012) en los términos de una tensión en las trayectorias de los jóvenes artistas que quieren desplegar una carrera, entendida como un itinerario dentro de una actividad estable y profesional, pero sólo alcanzan a producir proyectos, entendido como trabajo a destajo, "inseguro" o "precario". A pesar de que reconoce que "unos cuantos llevan de 10 a 30 años de actividad continua" (García Canclini, 2012: 16) entiende que estos itinerarios no constituyen una carrera, ya que implícitamente los compara con una instancia del capitalismo previa. Quizás casos como el estudiado exijan modificar los parámetros: desde el estudio del caso francés, Menger (2002) permite ver cómo en las características del trabajo artístico contemporáneo se revelan las mutaciones más significativas del trabajo actual: sus valores de alto compromiso con la actividad, autonomía elevada, flexibilidad, gratificaciones no monetarias, etc. La mirada de Menger es celebratoria pero permite entender que la carrera estable tal como la entiende García Canclini no es un valor para las relaciones de empleo engendradas por las mutaciones recientes del capitalismo. Para los miembros de Concepto Cero, el trabajo por proyectos permitía continuar formas redefinidas de la profesión, incorporando a la acción los datos de la nueva situación histórica que se ha venido describiendo.

Ahora bien, ¿qué dimensiones de la práctica musical emergente aparecen contenidas de manera privilegiada en las trayectorias anteriormente descriptas? Cada uno de los casos constituye vínculos singulares con la música pero que podemos considerar estructurantes de una situación de cambio en estos mundos musicales contemporáneos a la investigación realizada. 
La trayectoria de Cristóbal nos mostraba la manera en que la producción era clave para la profesionalización musical que requerían estas escenas emergentes, en particular por el lugar central que en ellas tiene la música en vivo. La realización de eventos, de hecho, fue la tarea principal a la que Cristóbal era convocado por fuera del sello. Sus amigos de Ciudad Alterna, para quienes Cristo trabajó, ilustraban a la perfección esta alternativa de trabajo en la música y al arte. Por otro lado, la producción contemplaba en el caso de Cristóbal la realización de otras actividades que exponían la música, como videos promocionales o video-clips, infaltables para estos artistas y abaratados sensiblemente en su realización. Durante el período de trabajo etnográfico, presencié la multiplicación de este tipo de emprendimientos volcados a la producción de contenidos, por parte de los propios sellos o de emprendimientos orientados específicamente a lo audiovisual. Como vimos, Concepto Cero realizaba sus propios videos, a la vez que bandas del sello trabajaron con Sonido Ambiente, un proyecto que se dedicó a filmar en vivo a músicos tocando en todo tipo de lugares. Conocí a este proyecto y a su creadora, Carla Sanguinetti, en una capacitación de Recalculando. Ella también se presentó como "gestora" de algunas bandas de la escena emergente porteña, como Morbo y Mambo. Más adelante trabajó en el Centro Cultural Kirchner como productora de contenidos y fue responsable, entre otras iniciativas, de ciclos musicales que combinaban bandas, Vjs y Djs.

Especialmente la trayectoria de Nicolás mostraba cómo la gestión cultural aparece como una posibilidad profesional de nuevo tipo, tanto en el sector privado como en el estatal. Nicolás se había consagrado a la gestión musical, con lo que consiguió trabajos por fuera del sello; por ejemplo, para bookear bandas o para organizar las grillas musicales de un evento. En el sector estatal, pudo presentarse como "capacitador" de bandas y sellos emergentes, una figura impensable años atrás. La profesionalización de la actividad por fuera de la industria musical tradicional producía un lugar para estas nuevas inscripciones laborales. Estos nuevos títulos de trabajo, del tipo 'organizador de eventos' o 'asesor musical', fueron identificados de forma pionera por Mc Robbie (2002) en su trabajo sobre las raves y la cultura del club en Londres. Tanto en el caso británico como en el argentino, estas figuras fueron estimuladas por las políticas públicas culturales. A tono con ellas, se producían cambios muy visibles en los perfiles de los funcionarios del sector cultural estatal: más jóvenes, especializados, actualizados y orientados hacia la gestión -como 
constatan los trabajos de Luker (2010), Infantino (2011) y Miguel (2012) para los funcionarios de las áreas de música, artes circenses y diseño, respectivamente, en la zona metropolitana de Buenos Aires.

La trayectoria de Matías, por último, nos mostraba una posibilidad de acción habilitada por el afianzamiento de un mercado de tecnologías musicales más baratas orientadas en principio a los usuarios domésticos, en la que suele entenderse como la “imparable democratización del mercado del audio" (Théberge 2006: 36). El detalle mismo de la posibilidad de armar y desarmar la sala me sugirió la relativa facilidad con que músicos como él podían empezar una carrera como productores de discos, un oficio históricamente muy costoso ${ }^{144}$. Es verdad que Matías no tenía los equipos más caros del mercado ni mucho menos -tenía "una placa más bien de home studio", como me dijo un colega-, pero la situación no dejaba de ser inédita. El hecho de que los músicos produzcan discos no es ninguna novedad, aunque esta opción no existió desde el comienzo mismo de la producción discográfica ${ }^{145}$. Actualmente, la posibilidad de que un músico emergente no consagrado produzca discos de otros artistas ha sido habilitada por la expansión de las nuevas tecnologías y de las micro-escenas. Es allí donde Matías se convierte en una opción interesante, y no sólo a la medida de sus amigos, aunque estos sean fundamentales en la acumulación de experiencia y reputación. Como él, también Shaman, Marina Fages, Lucy Patané y Damián Anache, otros músicos catalogados en el sello, produjeron en el período etnográfico discos de otros artistas con equipamiento propio. En estos casos se repetía la opción de grabar a los amigos, muchas veces miembros del sello: Anache produjo a

\footnotetext{
${ }^{144}$ Más adelante, conocí a unos músicos de Dice Discos que directamente trabajaban con un "estudio móvil", el cual armaban y desarmaban en los distintos espacios donde otros artistas de la ciudad los convocaran a grabar.

${ }^{145}$ Como señalan infinidad de trabajos, en el pop internacional la figura misma del productor de discos, generalmente entendido como productor artístico y/o ingeniero de grabación, traza sus contornos a fines de los años 60 y especialmente a principios de los 70 (Théberge 2006: 35). Di Cione (2009: 171) explicita que en el rock producido en Argentina la figura del productor artístico no siempre apareció diferenciada de la del productor ejecutivo. Arriesga que el primer productor artístico fue Billy Bond -asociado a Jorge Álvarez como productor ejecutivo-, quien produjo unos cincuenta discos en la década del 70. Luego de esta figura pionera, varios músicos claves para el rock argentino produjeron discos de otros colegas, generalmente en una lógica de consagrados y promesas. En el mundo del rock, un caso prototípico es el de Andrés Calamaro, quien trabajó durante la década de los 80 como productor para Berlín Records, una subsidiaria de EMI Odeón que buscaba nuevas bandas en el under de entonces. "En los 80 (...) ya era común que las bandas nuevas aceptaran que un músico más experimentado se hiciera cargo de la producción artística, como había sucedido con Javier Calamaro, que participó en la grabación de Los Pillos, o con Daniel Melero, detrás de los debuts de Los Casanovas y Sentimiento Incontrolable". (Sainz 2012: 181)
} 
Excursiones Polares y algunos temas de Brahmán Cero, mientras al término de la etnografía era una posibilidad que Shaman produjera el nuevo álbum de Sr. Tomate.

Hasta el momento de finalización de la etnografía estos trayectos personales vinculados a la música no podían subsumirse en figuras ya conocidas del mundo musical. Nicolás no era un manager, como Cristóbal no era un mero productor de eventos, ni Matías lisa y llanamente productor artístico. Si bien la especialización de las actividades y de las preferencias podía interpretarse de esta manera, cada uno de ellos actuaba en el marco de una configuración emergente específica que le daba rango de acción y sentido a estas actividades. Dentro de esa configuración busqué el destaque, en esta tesis, del sello musical, institución que redefinía estas posiciones y los vínculos entre ellas. Por lo demás, las propias ideas de los involucrados revelaban más bien un estado de cosas confuso o nuevo. Nicolás expresaba al respecto: “...estas nuevas dinámicas de personajes como podemos ser nosotros, que no somos ni managers, ni productores, ni netamente gestores culturales, sino que somos un poco de todo, además de músicos. Y que vivimos todas las problemáticas que tienen los músicos, como estar sentado en tu casa y decir 'qué quilombo hacer un show, ayúdenme"'. De esta manera, las aperturas y puntos de definición de estos roles y posiciones, su estabilización (o no) en el mundo musical estudiado: nada de ello está aún definido.

\section{"Estar en la música"}

Resulta significativo que en varias oportunidades a lo largo del trabajo de campo por ejemplo, en la anécdota en BAFIM que inaugura este capítulo- Nicolás se reivindicara como músico, a pesar de la ambivalencia que esa categoría tenía en la práctica diaria del sello musical. A partir de un pequeño rodeo armado con varios registros etnográficos introduciré esta ambivalencia e intentaré evaluar en qué sentido la gestión se volvía la habilidad central en el sello y, para algunos músicos como Ángel y Nicolás, no sólo un imperativo sino un verdadero placer y una forma elegida de vínculo con la música ${ }^{146}$.

\footnotetext{
${ }^{146}$ Sergio Pujol me señaló a Litto Nebbia como una de las figuras pioneras de músico-gestor, combinación que trataré en este apartado para el caso de Concepto Cero. En las numerosas entrevistas que Nebbia ha brindado sobre su actividad como responsable de Melopea Discos, se entiende que su trayectoria resulta una pista interesante para contrastar el análisis que propongo y discutir la singularidad histórica del caso. Esto
} 
El primer año de trabajo etnográfico (2011) me perdí una reunión en la casa de Matías porque no escucharon el timbre ni las llamadas telefónicas. Cuando les conté lo que había pasado y al observar mi simple Nokia 1600, Nicolás, un fan de las tecnologías que ya llevaba en su haber varios Blackberrys, Ipod y otros dispositivos de su clase, me dijo: "Tenés que tener un smartphone. Aparte ese día yo estaba conectado". Se sumaba así a varios pedidos de su parte para que me comprara uno de esos teléfonos, especialmente proyectaba que yo pudiera "tuitear en los eventos". Los demás lo acompañaban en este camino: al menos Cristóbal y Matías tenían sus respectivos smartphones ya en 2011, cuando esta clase de teléfonos móviles no estaban tan extendidos entre los jóvenes universitarios de La Plata. Estas tecnologías, especialmente por su conexión a Internet, eran fundamentales para la dinámica que le imprimían al trabajo en el sello: era usual ver a alguno de ellos tomar fotografías en los eventos para hacer promoción en vivo en las redes sociales virtuales, publicar tweets y posteos también en el momento, además de comunicarse entre sí para ultimar detalles. Para los miembros de un sello donde las actividades de gestión resultaban claves, estas tecnologías otorgaban a dichas tareas un componente de ejecución mayor. Durante un tiempo, incluso, Concepto Cero contó con un "celular del sello", un número que no era el de ninguno de sus miembros particulares sino del colectivo. A partir del caso de Fora do Eixo, Irisarri (2015: 57) muestra que la introducción masiva de tecnologías al trabajo diario de estos colectivos genera una dinámica de producción, circulación y consumo de bienes culturales que hasta hace poco era exclusiva de empresas con gran capital económico y simbólico.

Esta afinidad tecnológica no me llamaba la atención sólo a mí: al año siguiente consideraba hacerle caso a los chicos de Concepto Cero, y le comenté a Lautaro de TICA que quería comprarme un celular más completo para poder "anotar en los eventos" como el que estábamos, la inauguración del pre MICA (2012) en el salón dorado de la municipalidad de La Plata. Él replicó “ah, te querés comprar un Madoery ${ }^{147}$ phone”, para referir de esta manera los smartphones. La ocurrencia me causó mucha gracia y entonces le mostré mi Nokia 1600. Él me mostró el suyo, igual al mío, para luego asegurar que "el 80\% de los Uf Caruf tenemos este celular". Inmediatamente surgió la comparación con "los

exige, no obstante, un tratamiento más extenso que el que se puede realizar en el marco de la tesis y que espero realizar en futuras publicaciones.

${ }^{147}$ Este es el apellido de Nicolás. 
Concepto Cero y sus celulares pro", a lo que agregó en broma: "Nicolás te hace sentir para el orto". Riéndome le comenté que quizás podíamos suponer "una hipótesis sociológica que relacione los celulares y el funcionamiento de cada sello". Y él me contestó que sí, que encontraba "algo de la identidad" de cada sello en los celulares elegidos.

Esta hipótesis era más que un comentario perspicaz mientras esperábamos los anuncios de un acto. Cuando Lautaro presentaba el sello Uf Caruf en una capacitación de Recalculando reconocía que "en comparación con otros sellos" tenían carencias en "la parte más de la organización, de la gestión” y relacionaba significativamente esta situación con el hecho de ser "muy músicos, muy a los tumbos". La gestión era un esfuerzo que trataban de aprender de sellos como Concepto Cero con la perspectiva de que ese intento no comprometiera la "identidad". De alguna manera, en la perspectiva que Lautaro transmitía, la gestión podía implicar una "pérdida" de los valores que veían sintetizada en la lógica de la amistad con la que el sello se articulaba. En opinión de algunos integrantes de Concepto Cero "los Uf Caruf” eran "amigueros", lo cual les hacía apreciarlos, pero en contrapartida su sello resultaba una "anarquía".

En las palabras de Lautaro se filtraba otra contraposición repetida entre las redes de Concepto Cero: la que oponía distintas maneras de practicar la música de acuerdo a si incluía componentes de gestión. Desde la perspectiva de quienes se implicaban cada vez más en la gestión ser "muy músico" significaba desconocer esos componentes para entregarse al placer de la composición, la ejecución y la interpretación, olvidándose de que la música son también sus circunstancias. Así, en una reunión, quien estaba a la cabeza de uno de los sellos de TICA Red podía quejarse de estar "cansado de tratar con músicos" y de andar "corriéndolos a todos", siendo él mismo tan músico como los demás. A pesar de algunas críticas a los "músicos", quienes se empezaron a dedicar fuertemente a la gestión en Concepto Cero, primero Nicolás, un poco Cristóbal y luego Ángel daban cuenta de una elección y no de un mero imperativo. Para ellos se trataba de una práctica específica, basada en un saber que diferencian como tal, posible de dar ingresos y ya no obligada por las circunstancias sino elegida y placentera. 
El músico que no se ocupa de la gestión "muchas veces no entiende las complejidades que tiene", decía Nicolás en una entrevista pública ${ }^{148}$. Igualmente el tipo de artista con el que Concepto Cero se relacionaba solía compartir una concepción del músico como responsable no sólo de su obra sino de la gestión de ella, responsabilidad en la que el sello lo acompañaba. Las bandas que sólo buscaban el estrellato o, como decía Nicolás, "sacarse una foto con Pergolini sin importar cómo", eran un problema: cuando un grupo con el que se había trabajado en una edición decidió finalmente editar por otro sello, le pregunté a Nicolás el por qué y me explicó que “ellos se alejaron... mientras los tratamos como unas reinas estuvo todo bien, pero apenas dijimos de ponernos a laburar a la par no les gustó". Más adelante me confirmó que se habían ido con un sello que les iba a "bajar más plata". Como vimos en el anterior capítulo, los músicos de las distintas bandas que ingresaron luego de la formación original del "grupo de amigos" asistían a las reuniones del sello y algunos de ellos se incorporaron a actividades de gestión. Además se promocionaban entre sí y al sello como tal. No todas las bandas podían compartir este tipo de propuesta de trabajo.

Como ya fue señalado, las instancias formativas en la dimensión de gestión de la práctica musical se repetían bajo la forma de cursos, talleres y conferencias. Pero había algo más que aprender, pulir y poner a jugar en la gestión: una serie de habilidades que podemos denominar políticas. Gestionar no se resolvía en saber manejar adecuadamente las redes sociales, elaborar una estrategia de prensa convocante o conseguir unas luces "zarpadas". Había que practicar los "buenos manejos", tanto a nivel interno como con el resto de los actores de la escena. Para ello era necesario tener un conocimiento fino de la escena y sus distintos actores. Nicolás era quizás el que más atento a estas cuestiones, y en su cabeza guardaba un mapa interactivo de las simpatías, alianzas y enemistades del circuito, además de los vínculos que cada banda o sello tenía con las distintas instancias estatales, con las radios y periodistas y hasta con los bolicheros. Saber gestionar el conflicto, el llamado "ego" -en los términos del ambiente, un verdadero mal de los músicos-, los malos entendidos, resolver 'sobre la marcha', formaba parte del trabajo, tal como se observa en

\footnotetext{
148 "Uno habla de sello y es un comodín para decir un montón de cosas". Entrevista a Nicolás Madoery, Concepto Cero. Sin fecha, publicado en: http://www.elserviciopostal.com.ar/entrevistas/nicolasmadoery.html\#.UXApM6JLPrm (consultado: jueves 18 de abril de 2013)
} 
esta nota de campo correspondiente a uno de los tres días de recitales durante la presentación de "Los Ellos", a fines del año 2011en La Plata:

"Ahí nomás llegó al micro-cine [del Centro Cultural Islas Malvinas] Matías al grito de "no sabés lo que pasó". Luego nos saludó a Cata y a mí y además de un beso me dio unas palmaditas en la espalda. Nicolás lo miró un tanto desconfiado y preguntó “¿qué pasó ahora?”...

Matías: Supersivo no toca

Nicolás: ¿Qué? Me estás jodiendo...

Matías: No, Supersivo no toca, el bajista los acaba de dejar e irse

Nicolás no podía creer lo que le decía Matías, quien siguió explicando que el bajista no quería tocar con otro equipo de bajo, que se había calentado, se había ido y les había mandado un mensaje de texto ya fuera de la escena donde confirmaba que él no tocaba y que se buscaran a otro. Matías le pidió a Nicolás que fuera con él. Se fueron juntos y yo me quedé con Cata mirando las fotos del día anterior para subirlas a las redes sociales. Las había traído en un pendrive que conectó a la computadora Mac de Nicolás (...).

Al rato volvió Nicolás riéndose de lo "increíble" de Supersivo, "no se puede creer...", dijo. Luego le dio algunas indicaciones a Cata para que abriera la carpeta de fotos, que empezó a subir al blog de Concepto Cero, con su propio login. Al de Los Ellos no podía subirlas porque no tenía clave, a lo que Nicolás le dijo "pero para que te deslogueaste de mi cuenta, hubieras subido todo con la mía". Luego de subir las fotos, Cata le pidió a Nicolás que oficiara de "modelo" para unas fotos que le había pedido una amiga para un trabajo de la facultad (...).

Inmediatamente, Nicolás llamó a uno de los Toranzo para ver si venían a armar algo a la muestra o no. Según él, unos días antes había hablado con uno de ellos y le habían dicho que venían. Llama y luego de un par de frases introductorias dice jocosamente "¿mandaste algún delincuente para La Plata?". Evidentemente le dice que no, porque cambia de forma muy perceptible el tono de voz, se pone más serio y empieza a decir cosas como "nosotros habíamos quedado en...". El tono era serio pero en ningún momento violento, de hecho bajó la voz. Cuando terminó la conversación le dijo a Tadeo que él iba a pasar los visuales desde su compu porque los Toranzo no iban a venir, entonces ahora necesitaba otro cable y resolver algunas cuestiones técnicas. Tenía que ir a la casa a buscar unas cosas, dijo que se iba a ir en un taxi, del cual no lo vi partir porque justo me mandaron a la taquilla. Antes lo llamó a Pancho para decirle que le trajera el cable en cuestión. Mientras decía estas cosas y hablaba también con Tadeo, a Nicolás le sonaba el celular a cada rato (...). 
Entre las entradas y salidas del micro-cine, Nicolás entró con un músico de La Perla Irregular y dijo "Pablo me acaba de decir que se va de La Perla". El chiste era, obviamente, una ironía en relación al episodio de Supersivo. Mientras con Cata nos reíamos, el pibe puso caras de no entender nada. Nicolás le tuvo que explicar lo que había pasado. Pablo preguntó entonces si iban a tocar, y Nicolás dijo que sí, que recién los había convencido de que tocaran con un bajo electrónico, pero que iban a tocar tres o cuatro temas nomás."

Nicolás no era el único que practicaba continuamente estas habilidades. En ocasión de la organización de un festival, el sello invitó a una banda que no devolvió nunca una respuesta, por lo que los chicos entendieron que no sería de la partida. Apenas una semana antes, cuando ya estaban los flyers impresos y toda la comunicación realizada, un miembro de la banda los llamó escandalizado por su ausencia en la promoción, alegando que nunca se habían negado a participar. Cristóbal, luego de enojarse y de especular al respecto de la "falta de comunicación interna" en la banda y de adjudicarles "valor humano cero", dijo para todos: "pero si tocan hay que ponerle la mejor onda". Otro de los organizadores expresó con una expresión facial de fastidio su desacuerdo y al verla, Cristo lo miro y dijo “y sí...". La banda protagonista de este conflicto finalmente hizo su show en el festival sin problemas.

Gestionar era también, como decían en Recalculando, "tocar puertas", pero también "no apuntar mal" al elegirlas, tal como evaluaban retrospectivamente en Concepto Cero que les había sucedido al trabajar con algunos actores estatales. En este sentido, entender los códigos del mundo de la política era clave a la hora de la gestión. En una reunión del sello, Nicolás recordaba para Ángel y Damián cuando les habían “cajoneado” el proyecto de financiamiento de "Los Ellos" en el 2011. Cuando Nicolás dijo “cajonear" Anache reveló en su rostro cierta incomprensión $\mathrm{y}$, mientras nosotros continuábamos recordando el suceso, directamente preguntó qué queríamos decir con eso de “cajonear". Entre risas, Ángel le contestó "no podés ser tan músico... no puedo creer que no sepas”. Nicolás y yo también nos reímos y participamos de la explicación del término, ampliamente utilizado en el lenguaje cotidiano relativo a la política ${ }^{149}$. Este pequeño episodio volvía a poner sobre la

\footnotetext{
149 Cajonear, "acción de demorar el tratamiento de un asunto o expediente", es una expresión coloquial y familiar relativa a la política. DILE (Diccionario Latinoamericano de la Lengua Española). Universidad Nacional de Tres de Febrero. En la web: http://untref.edu.ar/diccionario/buscar.php?q=139\&p=cajonear
} 
mesa la especificidad del rol de la gestión y su distancia de los que persistían en ser "muy músicos". Sin embargo, los que podían ser considerados de esa manera tenían su opinión: en una ocasión, un músico de otro sello platense me interrogó sobre Nicolás en los siguientes términos: "Pero... ¿le gusta más la música o la gestión?”.

En ocasiones, esta tensión específica entre la música y la gestión podía hacer reaparecer la oposición entre el arte y el comercio en forma de acusaciones a los músicos que devenían gestores. En este sentido, durante un recital, un guitarrista de la escena que sabía que yo trabajaba con Concepto Cero me preguntó maliciosamente qué pasaba con la banda de Nicolás - que hacía tiempo que no tocaba- para luego sugerir que quizás su líder había focalizado demasiado sus energías en encontrar una "banda que la pegue" con el objeto de "hacer plata". En este punto, la imagen de sí que Nicolás podía encontrar en los demás nos recuerda a los sentidos que la tradición del rock ha sedimentado sobre las figuras del manager y del productor artístico del sector musical mainstream. Shuker (2005: 197) refiere a la fama del manager como manipulador de la música e imagen de los intérpretes. Quiña (2009: 6) sintetiza las ideas sobre el productor artístico que tienen los músicos independientes de la CABA: es el "representante de la industria", un actor que opera contra la "originalidad" y con "menosprecio de la música en beneficio del comercio". Ambas figuras se han asociado históricamente a la mercantilización de la producción musical, pero también a la profesionalización del artista.

Los propios implicados se desmarcaban de estas figuras clásicas para defender su novedad en el mundo de la música. En una ocasión, luego de un pre MICA conversábamos con Nicolás sobre algunos panelistas de una conferencia a la que habíamos asistido y él valoraba a uno de ellos en los siguientes términos: "es piola, pero él te da algo si vos le das algo, piensa como manager... qué tenés, qué tengo yo, a ver, vos tenés esto, yo pongo esto". Esta estrategia de toma y daca no era una con la que Nicolás se identificara, aunque declarase muchas veces realizar tareas de "management". En esta propia concepción de la actividad, el músico gestor se consideraba alguien más del grupo musical -aunque no tocara en él-, un par que apostaba por el conjunto. Es por esto que Nicolás podía decir: "No soy un manager, soy un agitador, manager es una palabra horrible", además de que sus tareas eran más amplias e integraban al management junto a otras actividades que realizaba con los artistas del sello. En las interacciones que tuve durante el período con otros 
participantes de la escena, pude comprobar que la crítica de esta categoría era más generalizada, incluso entre quienes contaban con un manager en su banda. En este sentido, esos músicos relativizaban al personaje en cuestión en los siguientes términos: “...bah, pero lo hace por amor al manager", "no pide plata ni nada", "nos ayuda".

Gestionar, hacerse cargo de los vínculos con el mercado y con el Estado, podía incluir muchas tareas: como describí en el caso de "Sueño Real", desde acompañar el armado de las canciones de un disco hasta diseñar una estrategia de promoción, hacer que cierren los números y realizar trámites legales. No obstante, había que lograr que entre todas estas actividades hubiera una conexión, un "plan integral" que no cualquiera con conocimientos en el mundo de la música podía realmente hacer. En este sentido, Ángel me hizo saber de las aventuras de gestión de un productor artístico de abultada trayectoria, a cuyas capacitaciones habíamos asistido en conjunto. Este productor había creado un sello con su propia casa editorial pero unos meses después, teniendo en su haber la edición de sólo un título -a nombre de una banda que él mismo había producido-, tuvo que ponerlo a la venta. Luego de hacerme partícipe de la noticia, Ángel me comentaba: "Por lo que me di cuenta [el nombre del productor] no entiende mucho de la cuestión negocio o de la cuestión gestión. Es un chabón que produce discos. Entiende de otras cosas. Se quiso lanzar a gestionar y es difícil, no es fácil... es toda una ingeniería la que está detrás”. El énfasis en el aprendizaje -de las particularidades técnicas y políticas del trabajo con las bandas, con el mercado y con el Estado- que frecuentemente sacaban a relucir los miembros del sello durante todo el período etnográfico daba cuenta de esta dificultad y comenzaba a ser un eje de diferenciación y de creación de la especificidad de este perfil.

Las figuras de manager, productor y otras asociadas a ellas se han comprendido de manera regular a partir del concepto de intermediario cultural. Desde una perspectiva bourdieana, Vecino (2011: 103) entiende a los responsables y dueños de sellos musicales de la CABA como "banqueros simbólicos", en el sentido de quien pone a la obra en relación con un cierto mercado, la representa y, fundamentalmente, "puede proclamar el valor del autor que defiende" (Bourdieu 2010: 156). Por su parte, el trabajo de Madoery (2010) sintetiza un punto de vista extendido actualmente sobre el productor artístico, al entender que este tiene una función de intermediación estratégica en el desarrollo discográfico de los artistas, por su posible función en la profesionalización de los materiales y su inclusión en 
ciertos mercados de la música. Más allá de sus diferencias, estas concepciones suponen que de un lado está la creación musical y la obra, del otro su circulación y comercialización y entre ellos una negociación protagonizada por el productor, el manager y los músicos entre los intereses "artísticos" y los "comerciales". Estas concepciones también suponen distinciones claras entre los "productores" y los "intermediarios". Por el contrario, considero que todo sucede en el medio y la música es el resultado de todas esas conexiones.

El trabajo pionero de Hennion (1989: 402) entiende al productor como un mediador entre la música y el mercado en un sentido diferente: no debemos considerar que entre la producción y el consumo hay un abismo, un punto de frontera en el que se abandonan la producción y sus técnicas y se da paso al "gran desconocido": el público y su gusto. El productor, en este sentido, no conecta dos mundos sino que los crea. Las versiones más avanzadas de este argumento, critican el uso de la noción de intermediario en tanto supone "una trasformación pasiva que solamente refleja o transporta otra cosa ya existente" (Hennion 2012, citado en Tironi 2012: 125), esto es la obra de arte. En contrapartida, "los mediadores no son simples portadores de la obra musical, sino que la constituyen". De esta manera, podemos entender las posiciones de Nicolás, Ángel, Cristóbal, Matías y otros de sus amigos en tanto figuras mediadoras y parte de las redes de actores y actantes por los que surge la experiencia musical que se analiza en esta tesis.

Al respecto, ellos mismos parecían actuar como unos muy reflexivos "profesores de sociología" (Hennion 2012 citado en Tironi 2012: 129) ${ }^{150}$ que me conducían hacia ese argumento. Nicolás solía decir de sí mismo que funcionaba como "una especie de link entre todo..." y Ángel, al contarme cómo interpretaba su posición en Concepto Cero me decía que era "estar en la música". Estar en la música contemplaba tanto tocar como gestionar, escuchar música y armar excels, como explicaba Ángel: "Estar tratando todo el tiempo con música". Para ellos, estas actividades eran plenamente creativas y si se volvían rutinarias, o como diría Cristóbal "chotas", eran parte de una relación con la música en la que esta se encuentra "en sus tareas profesionales, y no en otro lugar idealizado que haya de buscarse sin cesar fuera de las horas de trabajo" (Hennion 2002: 333). En una entrevista a la revista

\footnotetext{
${ }^{150} \mathrm{Al}$ referirse a los amateurs o amantes de la música, Hennion los nombra como "pequeños profesores de sociología, pequeños profesores de nuestra relación y vínculo con el mundo", con lo que quiere implicar "situar la reflexividad de su lado y no solamente en los sociólogos" (Hennion 2012: 129).
} 
platense La Pulseada, Nicolás decía: "El artista es creativo no sólo en lo musical, sino en cómo difunde su música, cómo consigue fechas, cómo genera redes. El genio y la creatividad en el arte están en todos los momentos" ${ }^{" 151}$. Desde mi perspectiva, Nicolás distribuía la creatividad en un amplio abanico de mediadores para romper nuevamente con una concepción romántica del arte asociada al genio. En este caso, esa ruptura se puntualiza en la indistinción cada vez mayor de la gestión/producción y la creación artística, y la difuminación del status del artista en el trabajo colectivo de una red, tal como plantea Irisarri (2015: 173) desde el caso de los productores de Fora do Eixo.

\section{El sentido de la profesionalización}

Como señalé en páginas anteriores, en la época de apogeo de las grandes discográficas, el disco resultaba el protagonista: las campañas de prensa y los video-clips se orientaban a promocionar los discos, los shows para presentarlos, las subas y bajas de la popularidad de los artistas se asociaban a la salida de nuevos singles. En este modelo basado en la cultura del fracaso -era preciso un número ingente de fracasos comerciales para lograr un éxito capaz de salvar esas pérdidas- el disco iniciaba el ciclo de la música, de allí la preponderancia de las grandes discográficas (Fouce 2012). Actualmente, cuando la clave del negocio ya no pasa por la producción y venta de discos, la profesionalización debe reformularse.

Para los músicos de Concepto Cero la profesionalización deja de encontrar en la industria discográfica un espacio privilegiado, y de manera concomitante, a la carrera exitosa en términos masivos como modelo de consagración. No se esperaba "la varita mágica", por lo que el interés radicaba en producir trayectorias sustentables y profesionales, en un proceso de crecimiento y de enfrentamiento a nuevos desafíos. En una conversación, Ángel y Nicolás enfatizaban el tiempo de dedicación que suponían estos desarrollos. Nicolás decía que los músicos "tienen que ponerle diez horas todos los días a lo que hacen”. Ángel completaba: "El tiempo que le dedicás a esto es lo que redunda en... no que te vaya bien, que tengas éxito, sino que se desarrolle, que funcione, que esté aceitado. Después te puede ir a ver cien personas, doscientos, quinientos, mil...”. Estas nociones eran compartidas en general por sus compañeros de escena y supone una novedad con respecto a

151 Celle J. (2013). Con el sello de la autogestión. Revista La Pulseada, 28 de abril de 2013. http://www.lapulseada.com.ar/site/?p=4996 (consultado: 3/05/2013). 
generaciones anteriores de músicos para quienes la profesionalización y la consagración pasaban en distinta medida por los mecanismos de la industria discográfica masiva.

Dada la centralidad que adquiere la propia gestión de la música para el establecimiento de una práctica profesional, el caso estudiado exige una manera distinta de entender la profesionalización a la que nos ha acostumbrado la bibliografía. La literatura entiende que se trata de un proceso por el que los músicos disputan un mejor lugar en el campo, evidenciado en el reconocimiento artístico por parte del público y la crítica especializada y por la obtención de mejores condiciones laborales. En una versión de esta interpretación, realizada a propósito de los músicos de folclore, Madoery (2010: 16) afirma que la profesionalización involucra "las condiciones laborales que se negocian continuamente y que tienen vínculos con los valores estéticos puestos en cada momento o escena musical en los modos de ejecución, composición y arreglo". En este tipo de conceptualizaciones, los músicos constituyen sujetos con competencias artísticas que, de acuerdo a los criterios de una escena musical específica, son pertinentes para realizar un trabajo de composición y ejecución/interpretación. Si usara una visión de esta clase para el caso en estudio no podría contemplar el cambio en el estatuto mismo de lo que implica ser músico, uno que ya no se dedica sólo "a tocar".

En efecto, para los integrantes de Concepto Cero "ser un músico profesional" requiere de otras disposiciones y habilidades además de las estrictamente musicales: especialmente la gestión de la música y la formación en la gestión. Es así que la definición de los criterios de la práctica y la identidad profesional legítima plantea diferencias con las denominadas "estrellas de rock", quienes tienen como objetivo "sacarse una foto con Pergolini", los que actúan como si los sellos fueran sus "papis" o incluso los "muy músicos" que no entienden "la complejidad de la gestión". Estas luchas por la legitimidad son características de mundos artísticos en transformación: el estudio de Irisarri (2011) sobre un colectivo de Djs de música electrónica de la CABA da cuenta de la pelea de estos por el reconocimiento de su actividad como profesional y por lo tanto rentada, donde los parámetros de lo profesional deben reformularse de acuerdo a la práctica de la mezcla de fragmentos musicales producidos originalmente por otros. El criterio de lo profesional en este colectivo contempla esta característica, resultado a su vez de una formación autodidacta opuesta a la formación institucional o escolarizada del músico. Para la escena 
electrónica cordobesa de los últimos años, Blázquez (2012) señala que para ser considerado un profesional y ejecutor de un verdadero oficio, el $\mathrm{Dj}$ debía poder mostrar que creaba sonidos propios, y por lo tanto era más que un trabajador que animaba fiestas, actividad considerada un "hobbie" o mero trabajo circunstancial. En otro campo de la producción estética contemporánea, Miguel (2013) muestra un proceso de inscripción de un nuevo tipo profesional que se inserta en el sistema de la moda de la CABA en los últimos diez años: el diseñador de indumentaria. Este graduado universitario que puja por un lugar en el mercado no se profesionaliza desde los criterios ya establecidos por un campo congelado. Por el contrario, ha aprendido y hace valer formas alternativas de encarar la producción de moda, no sólo en cuanto al diseño y la producción en sí, sino a los lugares de comercialización, muestra y difusión de los productos. De hecho, como muestra la autora, el sistema de la moda es transformado sensiblemente por la irrupción de estos profesionales.

En un argumento que engloba al anterior, el camino de profesionalización de Concepto Cero debe entenderse de manera multidimensional y específica: se despliega en una red de tecnologías, amistad y alianzas -institucionalizadas en el sello musical- entre músicos que devienen gestores y productores, que valoran el compromiso y el espíritu emprendedor. De esta manera, a tono con las prescripciones de Hennion para el estudio del arte, el objetivo no fue hacer una sociología de la música basada en las profesiones, un reduccionismo sociologista, sino una sociología de una música que se profesionaliza. 


\section{Capítulo V: Un relato para Concepto Cero}

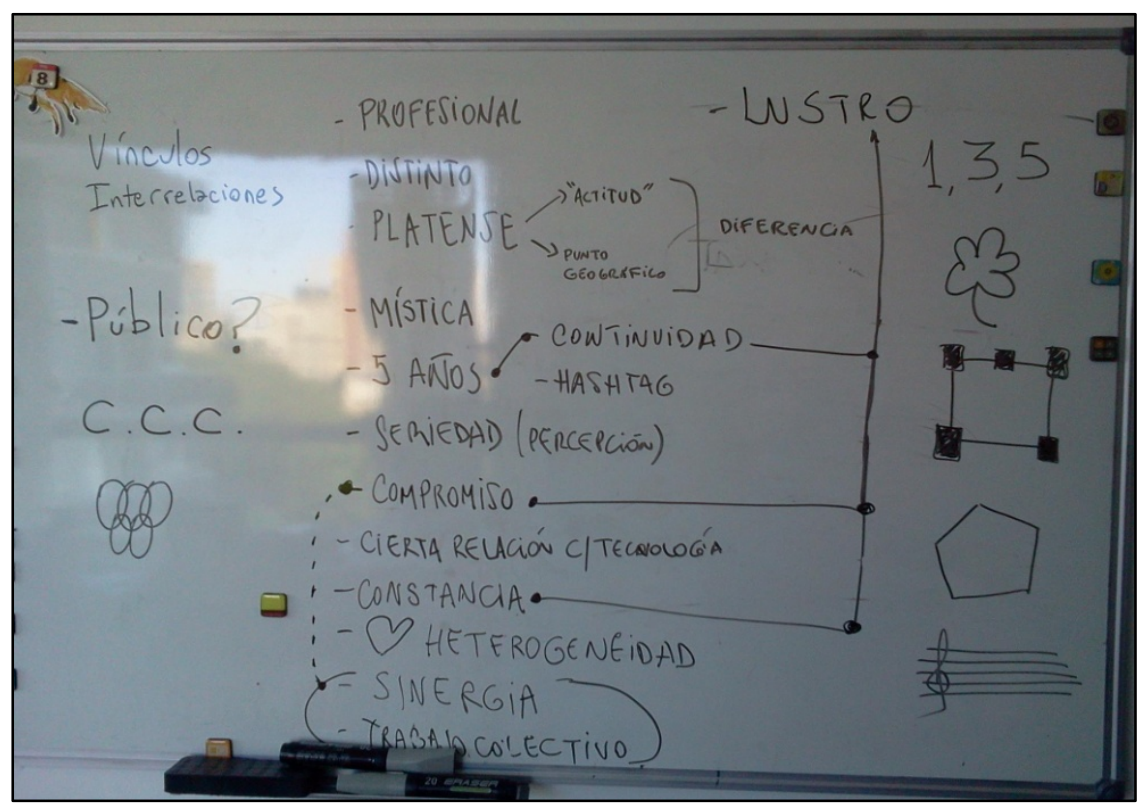

Esta es una fotografía tomada por Ángel durante un intercambio que tuvimos a fines de enero del año 2014, en el departamento de Nicolás; él mismo pegó la fotografía en un archivo llamado "MinutaReviewReunion27.1.14", donde resumió lo que habíamos conversado a pocos meses de que el sello cumpliera cinco años. El archivo, depositado en la carpeta "2014" dentro del Google Drive del sello, se corresponde con el último tramo de mi trabajo etnográfico. En aquella reunión Ángel, Anache, Cristóbal, Javier, Nicolás y yo discutimos acerca de lo que ellos llamaron "la identidad del sello". La foto captura un momento de cristalización de conversaciones que se producían regularmente en el grupo y pueden rastrearse en ella algunas de las dimensiones de la producción y gestión musical en Concepto Cero que trabajé a lo largo de estas páginas: lo profesional, lo comprometido, lo colectivo, lo platense, la relación con las tecnologías.

Si previamente me hubieran preguntado mi opinión sobre el tópico de la identidad del sello, habría pensado en buscar conexiones estéticas entre los distintos proyectos musicales que componían el catálogo. Pero para mis interlocutores la dimensión estética no 
resultaba ni principal ni única para abordar este problema. Esa tarde de enero nos preguntamos: ¿Concepto Cero es un sello platense?, ¿en qué sentido?, ¿cómo ellos creían que se percibía al sello en comparación a otros sellos platenses? ¿Por qué, según su perspectiva, el sello era distinto a otros? ¿Qué papel jugaba lo profesional en lo identitario? Finalmente, también hablamos sobre la identidad estilística de los proyectos: ¿cómo es posible en este proyecto específico fundamentar una identidad estética? No sólo la identidad del sello era un tema que los participantes tenían presente siempre y cada vez más con el correr de los años, también los criterios que usaban para discutir y reflexionar sobre ello revelaban una mutación particular en el campo de las sensibilidades en la producción y el consumo de música.

Retomaré los interrogantes de esa reunión de Concepto Cero a partir de la evidencia que brinda la totalidad del trabajo etnográfico realizado. Para empezar a tratar estas cuestiones describiré la práctica de escucha musical característica del grupo de amigos y su relación con las competencias profesionales, a fin de introducir los criterios más generales de vínculo con la música que se ponen en acción al momento de incluir artistas al sello y discos al catálogo. A continuación, analizaré esta lógica en su relación ambivalente con la amistad, como lazo estructurador del campo. Me preguntaré hasta qué punto la selección de artistas y discos puede englobarse en una estética, para lo que seguiré las propias derivaciones de mis interlocutores al respecto. Indagaré también en otras señas de la identidad apreciadas por ellos: las mediadas por el lugar y los objetos en la producción de música. A partir de todas estas discusiones, abordaré una pregunta que se hacían tanto músicos como analistas, aunque quizás activando sentidos distintos: ¿qué es lo nuevo en esta configuración musical?

\section{La escucha como práctica profesional}

Durante mi trabajo etnográfico rara vez vi a los músicos del sello entregados a tocar sus instrumentos fuera del escenario o de la sala de ensayo. Como muchas veces las reuniones del sello tenían lugar en cafeterías o en el hostel Frankville, discutíamos los eventos y lanzamientos próximos, poníamos en común ideas y proyectos, hablábamos muchísimo de música, pero no se tocaba música. No obstante, tampoco se ejecutaban 
instrumentos en otros encuentros a los que me invitaron, como fiestas de cumpleaños, asados entre amigos y compañeros. Pero sí se pasaba, escuchaba y hablaba de música. Sin excepción, mis interlocutores vivían comentando los materiales sonoros de otros artistas, el concepto y la estética de sus discos, sus recitales pasados y por venir, sus videoclips, etc. Especialmente las bandas que les gustaban y las bandas de la escena se convertían en un objeto que los invadía, parte plena de su cotidiano.

La dedicación a la escucha de los miembros del sello se podía observar en la regularidad con la que llegaban a las reuniones con auriculares, conectados al celular o a un reproductor de mp3. En sus casas tenían y valoraban los buenos parlantes y monitores de audio y cuando había reuniones siempre se escuchaba música de fondo. En varias ocasiones me sorprendí de su atención flotante a la música: absorta en las conversaciones de repente me daba cuenta que no estábamos escuchando el mismo artista que antes y al preguntarles al respecto del cambio me especificaban el nombre del artista y del disco sin reflexionarlo un segundo. Además, invertían en equipos de reproducción, y escuchar en diferentes formatos resultaba un verdadero acontecimiento para ellos: cuando Nicolás adquirió una bandeja para escuchar vinilos, Ángel, Cristóbal y Damián se acomodaron en almohadones para pinchar distintos discos y comentar sobre su sonido.

El siguiente fragmento de mi diario, fechado a principios de diciembre de 2011, durante un asado al mediodía días después de la presentación de "Los Ellos" en La Plata, introduce elementos del tipo de apreciación musical predominante en el grupo:

Estábamos todos apostados en distintas reposeras o tirados en el pasto en una especie de ronda. Tadeo puso en un reproductor chiquito que estaba sobre la mesa el primer disco del encuentro: era un original de Chancha Vía Circuito, específicamente Río Arriba, el último editado. Cuando se terminó este disco, no sabían cuál poner y entonces Cristo dijo algo así como "todo bien con este disco pero pongamos otro". Nicolás propuso poner a Los Polares, pero que no lo podía ir a buscar porque tenía las manos sucias, por lo que Cata fue a buscarlo a la habitación de Nicolás. (...) Mientras estábamos ahí escuchando el disco de Los Polares, ya para entonces estábamos comiendo los choripanes, Cata decía "me encanta este tema", alguien dijo de otra canción "es re Belle \& Sebastian", se hablaba también de una canción en la que participaba cantando Manza [músico y productor muy conocido de la escena independiente] y que no se lucía, porque cantaba a la vez que el cantante de los Polares. Julián, el hermano de Matías, dijo al comenzar un tema, "es igual al tema 
de Memphis La Blusera” y Nicolás “sí, yo se los re bardeé ese tema”, y Julián replicó corrigiéndose a sí mismo "no, no, es igual al de Manuel Wirtz", y empezó a tararear la melodía del famoso tema "Rescata mi corazón" -no sabía la letra-. Nicolás dijo que sí, que lo que pasa es que los Polares tenían mucha influencia del rock de los años cincuenta, tipo influencia de Elvis. A este respecto, Cristo acotó que "re daba" para que los Polares tuvieran unas coristas onda años 50. Todos nos reímos. El siguiente disco fue uno de Morbo y Mambo, que nadie dijo cuál era ni yo lo había escuchado nunca, aunque sí fui una vez a ver la banda en Mar del Plata y la reconocí. El hermano de Matías y su amigo no conocían la banda y entonces Tadeo les aclaró que se llamaba Morbo y Mambo. Se discutía si se parecían o no a Dancing Mood (...) Nicolás dijo "y bueno, ahora ya podemos poner los Ellos". Cuando empezó el tema de La Patrulla [Espacial] Tadeo acordó con Cristo en decir "uuh, este tema", "te hace subir". También se habló del tema de [nombre de una banda que aparece en el compilado] que a todos les había parecido choto en su momento pero, finalmente, era pegadizo, y lo cantaban. Julián dijo que hasta ahora sólo había escuchado dos veces el disco Los Ellos entero. Recibió expresiones faciales de enojo entre en serio y en broma y una frase de Nicolás: “¿cómo sólo dos veces?”.

Como puede leerse, estamos en una reunión, comemos y conversamos de otros temas -omitidos en este fragmento- y escuchamos música por placer -“me encanta...", "te hace subir"-, pese a lo cual la escucha es muy atenta. Una y otra vez el modo de escucha conecta unas músicas con otras, en una búsqueda de aires de familia. En el establecimiento de estos vínculos sonoros y estéticos, músicas que para el canon rockero son consideradas comerciales y vulgares -Manuel Wirtz- conviven con clásicos absolutos -Elvis Presley- y músicas de nicho o de "culto" tanto internacionales -Belle \& Sebastian- como locales Morbo y Mambo. Otra apreciación típica vinculaba el artista en cuestión con un sonido de época: "re daba" para que los Polares tuvieran unas coristas onda años 50. Para establecer estas conexiones es necesario escuchar varias veces los mismos discos, por lo que la poca dedicación a esta tarea de alguna manera se sanciona, especialmente cuando se trata de materiales propios o producidos en la escena de la que se sienten parte. Esto guarda relación con la instrumentalización que se realiza de estas escuchas a un nivel profesional: estar actualizado al respecto de los lanzamientos es central para decidir qué editar; para entender cuán "novedoso" o "riesgoso" resulta un lanzamiento.

Era inusual que refirieran a la música utilizando un lenguaje académico. Miembros del sello con una fuerte formación musical institucionalizada como Matías, Damián y 
Cristóbal podían llegar a hacerlo -“el bajo está a destiempo" o "la canción es jazzera por una cuestión armónica". Pero en general predominaba en los comentarios un tipo de apreciación que establecía conexiones con otras músicas y artistas, y que revelaba un conocimiento detallado de la historia de la música popular, producto de una dedicación cotidiana a la escucha, el manejo de los aspectos técnicos de la grabación y la lectura de las noticias y novedades del mundo de la música. En efecto, no sólo se vinculaba una música a otra música, sino a instrumentistas, productores musicales, estudios de grabación, modelos de instrumentos musicales (por ejemplo guitarras de tal modelo o tal año), etc. En una oportunidad, durante un cumpleaños, participé de una conversación en la que dos de ellos se retaban a reconocer un estudio específico en las grabaciones de cierta época del rock nacional porque el tipo de sonoridad lograda por la combinación de las características acústicas y la consola de ese estudio resultaba única para sus oídos entrenados.

Por otro lado, como podía escucharse en los "mixtapes""152 que subían a las redes sociales los distintos miembros del sello y en los "sets" 153 que armaban ellos mismos para las fiestas, el menú musical que el sello presentaba era amplio e involucraba estilos musicales alguna vez contrapuestos a nivel identitario, como el rock alternativo y el pop comercial o el rock clásico y la cumbia. Asimismo, revelaba el uso intensivo de Internet: provenía de geografías diversas y ostentaba la rareza de algunas selecciones. Por sólo retomar algunos ejemplos de mis registros: el electro pop ${ }^{154}$ de los suecos TheKnife, la electrónica de la sueca Fever Ray, el electro house de los franceses Jackson and his computer, el indie naif del norteamericano Daniel Johnston, el krautrock de los alemanes Neu, el proyecto solista de Jonsi, guitarrita de la banda islandesa de post rock Sigur Ros, la neo psicodelia de los australianos Tame Impala. Estos se combinaban con músicas más reconocidas en la industria musical: Massive Attack, Kanye West, Radiohead, Charlotte Gainsbourg, Public Enemy, Björk, Beastie Boys, The Ronettes, Madonna. En menor

\footnotetext{
152 Refiere a una recopilación de canciones recogidas de otras fuentes.

${ }^{153}$ Se hace referencia a una sesión de música a cargo de un DJ.

${ }^{154}$ Utilizo estas denominaciones comunes de la crítica y el periodismo musical especializado para dar una idea a los lectores del anclaje musical y estético de estos artistas. Simon Reynolds (2012: 177) realiza una interesante observación al respecto de la multiplicación de estos "géneros" cuando ya los géneros se han vuelto porosos. Adjudica su creación al expandido rol de curador que se observa en la cultura pop contemporánea en periodistas, críticos, djs, creadores de tendencias, etc. En general se trata de configuraciones de género retro-activas, acordes con el uso del pasado de la música como un gran archivo disponible para la creación musical actual. Por otra parte, estos géneros "novedosos" - entendiendo que su novedad es combinatoria pero no radical- tienen efectos en el mercado de exotismos y rarezas.
} 
medida, aparecían las novedades de la música independiente local y nacional, de la cumbia digital al rock pasando por el hip hop y experimentos con el folclore, donde escuchar a los amigos y colegas de la escena era lo regular.

Además de amplitud, en el tipo de selecciones presentadas se encuentra una búsqueda de la rareza alimentada por redes de jóvenes donde lo exótico es un factor de prestigio y se valoriza un conocimiento culto, hasta diría esotérico, de la historia de la música. En lo que respecta a su diversificación, este consumo musical no resultaba para nada extraordinario: la omnivoridad es una pauta generalizada del consumo musical que en el período estudiado atraviesa las escenas y las clases sociales. Gallo y Semán (2012: 152) ejemplifican esta idea al recuperar la experiencia de los trenes del suburbio de Buenos Aires donde los vendedores ambulantes se han dado cuenta la mayor rentabilidad relativa de ofrecer discos "compilados" de canciones de géneros y autores diversos.

No obstante, en el caso de Concepto Cero, el disco como unidad de escucha retiene su importancia en su versión física y convive con las versiones digitales. La señalada fragmentación contemporánea de la unidad de escucha hasta la canción o incluso fragmentos de ella (Yúdice 2007, Gallo y Semán 2012), que tenía lugar en los mixtapes del sello por ejemplo, no traía como efecto dejar de escuchar discos enteros. Esto puede asociarse a una forma de vinculación "melómana" -observable también en la persistencia con la que se adquieren discos físicos, lo cual será retomado más adelante- pero más que nada a una disposición profesional. Para personas que producen discos, como Matías, o que los editan y gestionan, como Ángel y Nicolás, la evaluación de un material sonoro se realiza integralmente. En una ocasión, Nicolás le contaba a Anache que le había escrito por Facebook una cantante y música de pop electrónico para participar del sello que a ambos les parecía "interesante”. Ella le había pasado unos temas que quería editar como disco, pero a Nicolás le pareció "que no estaba para editar", "le faltaba edición y concepto, una continuidad". Igualmente, como ya la conocía y le gustaba lo que hacía, la había invitado a conversar del tema.

Practicar la música no remitía para mis interlocutores solamente a "tocar", sino a escuchar música de forma muy activa, en el sentido del desarrollo de una competencia, tal como lo ha planteado Hennion (2010) en una discusión de la restringida noción sociológica de gusto bourdieana que ha contemplado el gusto desde el exterior, como resultado de una 
posición social, en lugar de ver allí un vínculo que produce al sujeto y al propio objeto de su afición. Para Hennion, la escucha no se limita a la realización de un gusto que "ya estaba ahí", sino que es una performance que precisa de técnicas, entrenamientos y pruebas repetidas a lo largo del tiempo. Podría decirse que para mis interlocutores esta escucha atenta, acumulativa, en distintos soportes de audio, extendida a numerosos estilos y geografías musicales y conectada a información muy específica que excedía la escucha como tal, era otra manera de "estar en la música", vinculada tanto al placer como al trabajo.

\section{Artistas y catálogo}

Durante seis años de funcionamiento Concepto Cero ha editado 21 discos, entre versiones físicas y digitales ${ }^{155}$. En su catálogo figuran los grupos y solistas Excursiones Polares, Shaman y los Pilares de la Creación, Sr. Tomate, Mariana Paragüay, Damián Anache, Lucy Patané y Marina Fages, Faauna, Míster América, El Perrodiablo, NDE Ramírez, Casimiro Roble, Brahmán Cero, Tata Laxague. Los ocho primeros son proyectos activos y cuyos artistas continúan en el sello, situación que en el lenguaje del grupo se nombra a partir de la expresión "los artistas del sello". Por su parte, El Perrodiablo y NDE Ramírez son bandas en funcionamiento y con discos catalogados en Concepto Cero pero que editan actualmente por otros sellos -aunque El Perrodiablo haya sido un "artista del sello" entre los años 2012 y 2014. Los últimos tres citados son proyectos inactivos: curiosamente, este último grupo reúne los proyectos del grupo original de tres amigos cuyos álbumes inauguraron el catálogo.

Para introducir al lector, puedo decir en tanto oyente que Excursiones Polares era una cuidada banda de rock que tomaba elementos del pop y la música country; Shaman y Los Pilares de la Creación, una propuesta rockera que tenía marcadas influencias del folklore; Sr. Tomate, una banda de rock con tintes de canción y influencias rioplatenses en las percusiones y la voz femenina; Mariana Päraguay, una cantautora que hilvanaba

\footnotetext{
${ }^{155}$ Los discos son los siguientes: Excursiones Polares: Grandes éxitos, Música Total; Shaman y los Pilares de la Creación: Shaman y los Pilares de la Creación, Quimera, Sueño Real; Fauna: Psicodelia cosa seria; Casimiro Roble: Volumen I, Volumen II, A saltar (simple); Lucy Patané y Marina Fages: El poder oculto;Sr. Tomate: Augurio; Míster América: ForExport; Tata Laxague: Dueño no tengo, Búcaro; N.D.E Ramírez: Refritos Vol. 1; Damián Anache: Capturas del único camino; El Perrodiablo: El Espíritu; Mariana Paraguay: Hilario; Brahmán Cero: Realidad/ansiedad; Concepto Cero por Concepto Cero; Los Ellos.
} 
diferentes enfoques de la canción con un aire folk y estilos musicales autóctonos; Damián Anache, un artista de la experimentación instrumental y con medios electro-acústicos; Marina Fages y Lucy Patané, dos multi-instrumentistas que generaban canciones con ritmos e instrumentos autóctonos con influencia del folklore argentino y distintas músicas del mundo; Faauna, un dúo que combinaba sobre bases electrónicas bailables referencias al rap y a la cumbia psicodélica; Mister América, una propuesta teatral y dramática deudora del art-rock; El Perrodiablo, un grupo con estructuras de hard rock y un registro sonoro distorsionado; NDE Ramírez, fusionaba instrumentos y melodías con raíces en el rock psicodélico y el folclore; Casimiro Roble, un power trío rockero que reformulaba el legado de Divididos; Brahmán Cero, un proyecto de canciones de bases electrónicas e influencia del rock industrial; Tata Laxague, un artista de música electro-acústica atonal, invadida por procesos digitales.

¿Cómo es que estos distintos artistas se encontraban en el mismo catálogo? Vecino (2011: 110) ha clasificado a los sellos de reciente creación de la CABA en dos grandes grupos en relación con la estrategia de formación de catálogo: los "cosmopolitas", poseedores de una línea estética muy cuidada que funciona como criterio de selección y edición de nuevos artistas, y los barriales, donde la formación del catálogo implica más un vínculo personal que decisiones estéticas. En el primer caso lo "innegociable" es la línea estética, generalmente a cargo de figuras que combinan las tradiciones del curador de arte y del empresario de riesgo -quizás el ejemplo de Jorge Álvarez resulte esclarecedor de esta figura-, mientras que en el segundo lo "que prevalece sobre cualquier otra consideración y tiende a orientar las decisiones comerciales" no es otra cosa que la complicidad que define a la amistad en este campo. Como veremos en el caso de Concepto Cero esta complicidad, sin embargo, no es absoluta ni deja de estar sujeta a reformulaciones. Una breve historia de campo nos permitirá introducir esta cuestión.

Al término de mi trabajo etnográfico, mientras finalizaba una entrevista a un músico que conocía por participar de Recalculando, llegaron a su casa unos amigos de su sello. Los conocía de ir a verlos a tocar y me invitaron a cenar. Acepté y luego de la cena, mientras recordaban cómo se habían conocido entre sí, uno de ellos desliza: “Qué mal lo que pasó 
con Pedro, que le echaron abajo el EP ${ }^{156} \ldots$.., y continúa: “¿Cuál es el problema si hace EP? Yo también hago EP, le dijeron que haga un disco, pero si el sello saca EP...”. Uno de sus amigos le contesta: "Bueno, pero lo de Pedro no tiene tu nivel de producción". Su amigo le dice que no está de acuerdo pero igualmente si así fuera por qué no le iban a sacar el material. Plantea que entiende que Pedro es un "colgado" y que eso a Gus [refiere a otro músico del sello que le estaba produciendo el disco] le molestó, pero que eso no es suficiente para "bajarle el EP”. Un tercer participante de la conversación, realmente compungido por el tema, afirma que “es re amigo, ¿cómo no le vamos a sacar el disco?”. Recuerda entonces no haberlo visto más en las "zapadas", 157 , y reafirma: "Es un amigo, una persona que no nos va a pedir algo que el sello no le puede dar".

Esta escena inmediatamente me reenvió a la sorpresa experimentada -allá por el año 2011- por el hecho de que la banda punk que por entonces tenían Tadeo y Mariano no fuera editada por Concepto Cero. En su momento no indagué específicamente a qué se debía y no supongo aquí, al retomar dicho caso, que la situación haya sido similar a la etnografiada tiempo después. Esta escena posterior, más bien, me hizo percatar de que la pregunta que debía formular era más general ${ }^{158}$. A todas luces, los sellos que hacían de la amistad su lazo estructurante y de la gestión colectiva su manera de funcionar no editaban a todos los que consideraban sus amigos. Incluso en un emprendimiento que comparado con Concepto Cero resultaba más vocacional, se producían conflictos entre quienes de alguna forma privilegiaban el catálogo - desde el parámetro de la calidad de producción en este caso- y quienes pensaban que no podía negarse a los amigos un lugar en él.

¿Cuáles eran entonces los criterios por los que Concepto Cero sumaba a ciertos artistas a trabajar? Refiero especialmente al catálogo, aunque también a bandas con las que se trabajaba en booking. Siguiendo mis primeras observaciones y conversaciones, podía afirmar que el reclutamiento de artistas tenía lugar de manera predominante a través de redes de personas ya conocidas. A pesar de que estos sellos recibían mensajes por correo

\footnotetext{
${ }^{156}$ Del inglés extended play, el EP originalmente era un vinilo de 7" que se diferenciaba del simple porque se reproducía a una velocidad más lenta por lo que podía contener dos canciones del mismo lado. Actualmente, el EP se utiliza como formato más largo que la canción pero más breve que un disco (long play) ya no por razones técnicas sino por decisiones estéticas y comerciales (Del Águila, 2015: 19).

${ }^{157}$ Para el grupo de amigos de este sello era común reunirse en las casas de los distintos músicos a "zapar", es decir, a improvisar pasajes sonoros con distintos instrumentos, que intercambiaban entre ellos.

${ }^{158}$ Aunque con esto no repongo no haber indagado en su momento a Matías, Nicolás, Tadeo o Mariano por aquello que me sorprendió.
} 
electrónico y las redes sociales virtuales con demos y ganas de participar en el sello, esta no resultaba una vía de inclusión de nuevos artistas. Ángel me lo confirmaría años después: “Todos los días llega: 'estamos sacando un disco, te paso los demos'. Y hay cosas súper bizarras. Y cosas que están bien”. Pero dejaba en claro que, para entrar en relaciones por esa vía, el material "tiene como que tener algo re atractivo... por lo general es gente con la que ya hablamos, nos conocimos en otro espacio".

A partir de mi permanencia etnográfica pude notar que era el contacto dilatado en la escena el que generalmente producía asociaciones que culminaban en la inclusión de las bandas al grupo de artistas de Concepto Cero. El Perrodiablo se incorporó a fines del año 2011 luego de la presentación del álbum "Los Ellos" pero ya en las reuniones de abril Nicolás sugería como posibilidad que esta banda pasar a formar parte de las filas del sello. Ese año la banda fue invitada a otras fechas y su cantante agradecía por micrófono "a Concepto Cero por tenernos siempre en cuenta”. Como El Perrodiablo, otros grupos que participaron de ese compilado se incorporarían a trabajar con el sello: Shaman y Los Pilares de la Creación era uno de ellos, al igual que Mostruo, que no editó discos propios aunque si delegó el booking y participó en el compilado Concepto Cero por Concepto Cero (2012). De la misma manera, la relación con Marina Fages había comenzado con "Los Ellos", donde ella había participado como ilustradora. En 2013 el dueto musical de Marina con Lucy Patané fue trabajado y lanzado por Concepto Cero. Durante los años que median entre su participación en "Los Ellos" y este lanzamiento, Marina había tocado en La Plata invitada por el sello y compartido muestras y otras actividades con Tadeo. En el año 2012 Marina y Lucy habían abierto una disquería llamada Mercurio en la CABA con otros $\operatorname{amigos}^{159}$, en la que se empezaron a vender discos de Concepto Cero.

Muchas veces estos contactos se habían iniciado por invitaciones a tocar en el hostel o a participar de fiestas organizadas por el sello. En una reunión en la que consideraban si seguir o no con el ciclo por falta de personas que se encargaran de la producción, Cristóbal

\footnotetext{
${ }^{159}$ En relación con la valorización del disco físico que señalaba antes, en una entrevista online Lucy Patané ampliaba la lógica que supone el disco en el mundo musical en análisis: "Nuestro slogan es 'Escuchalo online, conseguilo en Mercurio'. Porque la gente, en este sentido, sigue apoyando a las bandas. Porque también quieren tener el disco de la banda, eso sigue pasando. Y también pasa que viene mucha gente a que les recomiendes un disco. Hoy, con tanto acceso a internet, está re bueno que no se haya perdido que alguien venga y te pregunte por una recomendación. Y de repente recomendás discos que están geniales y son los discos de tus amigos, porque conoces a casi todos los músicos de los discos que están ahí...”. En: Feldman, Gabriel. "Los productores \#20: Lucy Patané.", con fecha 30/10/2015, publicado en: http://artezeta.com.ar/los-productores-20-lucy-patane/ (consultado 3/01/2016).
} 
argumentaba que este era fundamental para "sumar bandas nuevas". En efecto, la primera banda que había ingresado al sello luego de los tres proyectos musicales de los amigos fundadores fue Excursiones Polares, y lo hizo a partir de una visita al ciclo del hostel mediada por Anache. Así lo contaba Ángel: "El Tata se lastima la... Ahora ya sé que es el Tata, pero en el momento, tipo 'el guitarrista de una banda se lastimó la mano'. Entonces esa noche Anache le dice a Nico, 'che, tengo unos amigos que tienen una banda que está buena'. Mati y Nico eran Concepto Cero. A Mati le gustó muchísimo, y a Nico le caí... no sé, porque a Nico le gusta otra música, pero a Nico le caímos muy bien, como muy bien. Y pegó mucha onda con Roy, y después al tiempo lo invitó a Roy a pasar música en alguna fecha".

Pero no todas las bandas que eran invitadas a fechas del sello eran consideradas viables para trabajar con él. Primero, porque a veces esas invitaciones recaían en bandas que no gustaban: una noche en el hostel, en la que un dueto tocaba canciones melancólicas y abúlicas, a Nicolás le pareció que la banda resultaba buena "para dormir", a Pancho que lo ponían "muy abajo" y a Matías que era "monotemática” y tenía "un mal cantante". El criterio del placer estético era clave: las bandas tenían que gustarles. Pero la afinidad estética no bastaba sino se compartían las mismas reglas de trabajo. Como vimos en el capítulo IV, las bandas tenían que trabajar a la par del sello. En una ocasión, Nicolás y Cristo hablaban de una banda que finalmente no ingresó, con la que habían compartido varias fechas. Les parecía una banda musicalmente interesante y por ese motivo sus integrantes habían conversado en distintas instancias con Nicolás para incluirse en el sello, pero según afirmaba categóricamente Cristóbal: "son unos jipis, no se puede trabajar”. Hacía referencia a varios episodios problemáticos: tocar más de lo acordado en una fiesta, llegar tarde a armar el escenario, abandonar una fecha a último momento, planificar un proyecto y luego no sostenerlo, etc.

Hasta aquí vemos cómo en Concepto Cero los criterios de la afinidad estética y ética, es decir, lo que denominamos como amistad, eran determinantes para incluir nuevos proyectos. Lo mismo sucedía en otros sellos que habían participado de la red TICA. Indagado al respecto, Diego de Desde el Mar señalaba: “[las bandas] tienen que tener esa particularidad de que tienen que, tienen como que gustar a todos...estéticamente. Y aparte tienen que tener una forma de trabajo similar a...O sea, tienen que integrarse a trabajar". 
Pero desde el año 2012 Concepto Cero comenzó a incluir en el catálogo discos de artistas que no eran amigos. Es el caso de NDE Ramírez, un proyecto de Formosa que se definía a sí mismo como "colectivo multimedia de folk rock" y sumó uno de sus discos. Nicolás, que lo había conocido en un pre MICA de la región NEA, lo explicaba así: "Al loco [refiere al líder de la banda] le sirve, a nosotros nos sirve porque es como algo para intercambiar y al loco le sirve que yo lo mueva en un montón de lugares en donde estoy y sepa que él acá tiene como una especie de representación. Porque la banda ya está como en otra, no es que está empezando. Él es un tipo así re independiente, que le propusimos algunas pautas. Y... está bien digamos llegamos a un acuerdo" ${ }^{\prime 60}$. Al cabo del acompañamiento etnográfico, proyectos musicales como Faauna, un grupo pionero de la cumbia electrónica porteña, y Míster América, un antológico grupo de rock platense, se acercaron a trabajar con el sello desde una posición similar: con gran trayectoria y en cierto sentido ya "consagrados", a diferencia del resto de los $\operatorname{artistas}^{161}$.

Podría decirse que estas inclusiones eran más "estratégicas" que las de los amigos que inauguran el catálogo, aunque sin perder de vista que todos los lanzamientos suponían una estrategia. A través de la red de amigos y conocidos, Concepto Cero no dejaba de pensar estratégicamente los ingresos, en relación con la ampliación del público y la producción de lazos de familiaridad estética y sonora entre los artistas. Por ejemplo, cuando se incorporó El Perrodiablo los miembros del sello no estaban entusiasmados sólo porque les gustaba la banda y se llevaban bien con sus integrantes sino porque observaban en ella un potencial para atraer público hacia otros artistas del catálogo. De la misma manera, cuando Nicolás comenzó a conversar con Mariana Päraguay inmediatamente me planteó que no sólo "había que editarla" porque era muy buena compositora y cantante, con una "onda" distinta a otras cantautoras de su generación, sino que era una manera de que el sello consolidara una línea estética afín a lo que en años recientes se ha dado en llamar

\footnotetext{
${ }^{160}$ A partir de este caso puede verse cómo si bien las redes se trazaban por lo general en la zona metropolitana de Buenos Aires, no siempre se limitaban a lo local. El otro caso es el de Mariana Päraguay, a quien Nicolás conoció en Mendoza por un viaje de Recalculando. Los viajes de TICA Red y Recalculando le permitieron a Concepto Cero establecer conexiones con artistas de otras provincias.

${ }^{161}$ La participación de estos artistas en el sello advierte sobre un posible cambio en el funcionamiento y la propia continuidad de un "grupo de amigos" que no pudo ser registrada debido a que cuando estos grupos se sumaron ya no estaba involucrándome en plan etnográfico con Concepto Cero.
} 
"canción" " Esto les permitía sumar a Mariana a la línea que habían armado con Shaman y los Pilares, y Marina Fages/Lucy Patané, presentada el año anterior para los amigos y la prensa. Esta estrategia de presentación consistía en un sobre de madera lacrado que contenía los dos discos correspondientes. En su interior, un folleto también en papel madera introducía: "Con un espíritu en común, folclórico, simbólico y espiritual, se encuentran dos discos por destino o casualidad. Lucy Patané y Marina Fages trabajando en conjunto en $\mathrm{El}$ Poder Oculto (...) Y el homónimo de Shaman y Los Pilares de la Creación”.

Percibimos entonces cómo a medida que Concepto Cero avanza en "compromiso" va planteando un estándar de calidad y criterios estéticos más consistentes. Es verdad que, como reconstruyo más adelante, estos criterios se arman "sobre la marcha" y no obedecen a una línea editorial ni a un criterio previo de un curador empresario, tal como planteaba en su oposición entre sellos cosmopolitas y barriales Vecino (2011), pero igualmente es lo bastante fuerte para clausurar las posibilidades de que algunos amigos editen. Ello no sucede porque estos finalmente no sean tan amigos, sino porque su inclusión compromete alguno de los criterios que van justificando el catálogo - con la misma lógica que Concepto Cero no va a editar una banda de "género" como puede ser el punk, el sello que vimos al comienzo del apartado se propone ciertos estándares de calidad. La amistad, entonces, es condición necesaria pero no determinante a la hora de trabajar con un artista.

Los diferentes artistas de Concepto Cero que fui nombrando no tenían los mismos vínculos entre sí y con el sello. Damián y Ángel de los Polares formaban parte del núcleo duro de gestión del sello. Por su parte, algunos miembros de los Pilares y de los Polares asistían de manera regular a las reuniones, discutían con los demás acerca de los proyectos del sello y algunos de ellos incluso intervenían en algunas actividades de comunicación y diseño. Existía otro grupo de artistas con el que se encontraban de manera más esporádica. Luego estaba el grupo de artistas que tenían discos en el catálogo pero que no se vinculaban por otros motivos con el sello. En una reunión de principios del año 2104, Nicolás dejaba entreverlo de la siguiente manera:

\footnotetext{
${ }^{162}$ En los últimos años, la crítica y el periodismo especializados han usado el término "canción" para referir a la mixtura de distintos géneros y estilos musicales generalmente hechos por jóvenes que encuentran en el rock su educación sentimental pero que consideran que "el rock no es el centro del universo musical" (Graziano 2011: 13). Se trata de bandas o cantautores -o los intérpretes que el citado texto de Graziano llama "cancionistas"- que abrevan en los distintos folklores, el jazz, la canción latinoamericana, el tango, la chanson, etc. La escena de música popular platense presentada por Del Mármol, Magri y Sáez (2014) cuenta entre sus filas con exponentes de la canción así entendida.
} 
Luego de ir a la panadería a comprar facturas para la reunión, entré de nuevo al departamento y Nicolás se me puso a mostrar un powerpoint que había hecho. Tenía varias diapositivas con títulos como: "relato", "objetivos 2014", "presupuesto" (este último eran más bien anotaciones de cuánta plata le debía el sello a tal o cuánta plata tales le debían al sello). Otra diapositiva explicitaba la estructura interna del sello y el tipo de cosas que hacía: por ejemplo, producciones para terceros, producciones (al preguntarle me dijo que refería a las internas, por ejemplo las fechas del sello), booking, entre otros. En otro cuadro estaba representado un gráfico con los diferentes vínculos del sello con artistas. Este era un dibujo de un núcleo y círculos concéntricos que se iban alejando de él. En la primera línea cercana al núcleo estaban Shaman y los Pilares, Excursiones Polares y Anache. En la segunda, Fages y Patané. En la tercera, Casimiro Roble y El Perrodiablo. En la siguiente aparecía La Patrulla Espacial [editada por CC sólo en el caso del compilado Los Ellos]. Y en la más alejada de todas, Güacho. Le pregunté a Nicolás la lógica con la que había armado este gráfico de círculos concéntricos y me habló de la mayor cercanía o lejanía con respecto al sello. Me dijo que La Patrulla aparecía porque hacen cosas con ellos (de hecho, se estaba hablando para el contrato de distribución digital con Believe y me recordó el temario de la reunión) y Güacho como ejemplo de las relaciones que se podían tener con otras bandas. Por su parte, él creía que ahora que Cristo se iba a Tucumán no iba a tener la misma comunicación con Casimiro, que además tenía problemas para reemplazarlo con otro bajista.

La clasificación que Nicolás realizaba de los artistas del sello revelaba un mapa de los vínculos personales y el compromiso con el sello que no pueden ser captados desde una lógica del catálogo. Puede observarse que los llamados "artistas del sello", es decir con los que este trabaja, no coinciden punto por punto con los artistas del catálogo. En la misma lógica, algunas bandas que no estaban en el catálogo -La Patrulla Espacial y Güacho- eran mejor consideradas que otras que sí pertenecían a él y que directamente no aparecen representadas en el gráfico. Esto diferenciaba nuevamente a Concepto Cero de los sellos discográficos tradicionales, donde el catálogo es el motor de la organización y el ordenador de las relaciones con los artistas, gestionado por lo general desde divisiones estéticas por géneros musicales, perfiles artísticos y relación con el mercado (Negus 2005). En Concepto Cero, por el contrario, los artistas se jerarquizaban de acuerdo a su participación en la gestión del sello. Desde mi punto de vista, lo que Nicolás ponía sobre la mesa con este dibujo era la manera en que el sello priorizaba las relaciones de trabajo por sobre aquellas 
exclusivamente estéticas. Estas conexiones dibujaban una red de mediaciones donde el valor de la amistad resultaba central y que determinaban lo que finalmente se agrupaba o no dentro del sello. Por lo demás, Nicolás ponía de manifiesto su propia reflexividad acerca de la unidad social en la que producía música.

\section{De las referencias estilísticas a un relato del proyecto}

Cuando empecé el trabajo etnográfico, le pregunté a Nicolás por la línea estética del sello y me dijo “ahora es súper heterogéneo". En realidad, con mi pregunta había marcado una preocupación que ellos mismos se encargaron de redefinir varias veces durante el período estudiado, ¿qué es lo que unía a los distintos proyectos musicales del sello?, ¿es que ese hilo era estético? En esa oportunidad, Nicolás también me dijo: "Nos planteamos trabajar dentro de electrónica y rock, cosas que nos gusten". Al desplegar esas dos categorías en una enumeración de los distintos artistas la amplitud estilística resultaba evidente: "Tenemos una banda de canciones así más indie [Excursiones Polares], otra banda un power trío, onda Divididos [Casimiro], mi banda que es rock industrial electrónico [Brahmán Cero]. Y bueno, está acá El Tata que tiene un proyecto de electrónica con folklore, y otro más de electrónica experimental". Así, cuando hablaba de "rock" y “electrónica", Nicolás no se refería a definiciones estabilizadas de género musical: el criterio de producción y consumo estético de los miembros asumía plenamente la relación más abierta y menos codificada con los géneros musicales ya constatada para otros contextos (Ochoa 2003, Semán y Vila 2008, Semán 2011).

En una apuesta que respondía más a las orientaciones estéticas de los integrantes del sello que a una línea estética definida a priori Nicolás dejaba abiertas otras posibilidades: "Que nadie dice que un día venga un loco haciendo folklore, cumbia, y no me cierre y le digamos de laburar con nosotros, porque va por otro lado”. Nicolás adelantaba en el año 2011 lo que finalmente ocurrió años después: una banda de cumbia electrónica -Faauna- y proyectos vinculados al folklore aunque de ningún modo "folclóricos" -Shaman y el dueto Fages/Patané- se incorporaron al sello. No es que Nicolás ejerciera la adivinación o siguiera un plan estratégico de formación de catálogo: estas alternativas ya estaban

disponibles en su mundo musical. Como plantean recientemente Gallo y Semán (2012: 
153) las nuevas tecnologías y la liberalización del gusto musical hacen que los jóvenes conformen su menú musical de manera activa y reflexiva, a tal punto que se sustraen de criterios de autoridad que "no sólo remiten a las instancias clásicas de la crítica, la mediación o la cultura oficial, sino también a mediaciones tales como el gusto por 'géneros musicales"".

Si bien la mayoría de las formaciones catalogadas de Concepto Cero utilizaban una instrumentación clásica de bandas de rock - guitarra, bajo, batería- a la que de acuerdo al caso sumaban instrumentos de viento, otros instrumentos de cuerda, teclados, sintetizadores, etc., la música producida bajo su auspicio difícilmente podía englobarse en un "sonido" reconocible, a diferencia de lo predicaban otros sellos de La Plata y de la zona metropolitana de Buenos Aires. De Scatter Records, por ejemplo, su director afirmaba que se trataba de un "sello de garage" 163 y que tenían una "idea estética precisa". De Laptra, uno de sus responsables decía: "Las bandas tienen una retórica muy definida, una instrumentación particular, una lírica, un anclaje visual" ${ }^{164}$. En contraste, Concepto Cero proponía crear "una identidad desde la heterogeneidad, y un concepto interdisciplinario, desde el rock a la electrónica, desde la ilustración violenta a la fotografía más pura” (Google Drive 2011). Bastante avanzado el trabajo de campo, Ángel continuaba este discurso de la heterogeneidad: “A mí no me gustaría estilísticamente tener un sello, tipo de post-punk o, no sé, o todo de cumbia. No me seduce eso. [Los artistas] se empiezan a repetir, viste. Todos medio parecidos...". Nicolás en el mismo sentido expresaba su idea de que "lo ecléctico sea como una característica de lo nuestro" "165. En este sentido, el concepto de catálogo de Concepto Cero se acercaba al de otros sellos de similar escala, como Triple RRR o Estamos Felices, para quienes como decía Martín Mercado, "lo divertido es no encajar en un sonido".

Como se plantea habitualmente, la mezcla es un criterio de producción central para la música juvenil contemporánea. Ahora bien, ¿en qué sentido este criterio se distinguía de

\footnotetext{
${ }^{163}$ El garage -a veces también "garage rock", tal como aparece en las publicaciones de este sello en Facebook y otras redes sociales- refiere a un conjunto de estilos musicales inspirados en el rock and roll clásico y caracterizados por un sonido crudo, enérgico y minimalista.

164 "FestiLaptra 10 años". Entrevista a Javier Sisti Ripoll, con fecha 27/11/14, publicado en http://www.losinrocks.com/musica/festi-laptra-10-anos\#.VqQlM5rhArg, (consultado 5/01/16).

165 "Uno habla de sello y es un comodín para decir un montón de cosas". Entrevista a Nicolás Madoery, Concepto Cero. Sin fecha, publicado en: http://www.elserviciopostal.com.ar/entrevistas/nicolasmadoery.html\#.UXApM6JLPrm (consultado: 18/04/2013)
} 
experimentos de mezclas realizadas en otras épocas de la música popular? Vila (1987: 24) ha planteado que la mezcla es una característica del rock nacional clásico, tanto como del folclore y del tango, diferenciándose en el contenido de dicha mezcla. De acuerdo a su interpretación, en distintos momentos de su historia y de manera variable, el rock nacional se ha relacionado con el rock and roll, el blues, el pop, el rock sinfónico, el punk, el jazz, la new wave, el reggae, el ska, el rockabilly, la música clásica, la bossa nova, el tango, etc. El criterio de esta mezcla tal como la entiende Vila es la fusión en la que los géneros continúan claramente delimitados, además de que se mixturan sus versiones establecidas o vanguardistas. Por el contrario, la mezcla tal como se la comprende y practica en nuestro caso, y en otras manifestaciones musicales contemporáneas -por poner sólo unos ejemplos: el "cancionismo" de Graziano (2011), los samples y remixes del colectivo musical Zizek etnografiado por Irisarri (2011), la propia reunión sonora inclasificable en la música indie platense (Boix 2013)-, apela a la de-construcción de los géneros, su puesta en contradicción hasta el estallido. Estas mixturas se refuerzan por la amplitud de lo que se pone en contacto luego de que se ha producido una apertura estética a lo antes rechazado observada de forma paradigmática en el acercamiento actual del rock a la cumbia y a la llamada “música comercial”. Por estos motivos, Gallo y Semán (2012) proponen usar la expresión transgenericidad musical en lugar de la de mezcla, a fin de dar cuenta con mayor precisión del tipo de relación deliberadamente disruptiva que estas propuestas establecen con los géneros musicales.

Todo esto no significaba que no hubiera complicidad estética en el sello. Durante la mayor parte del trabajo etnográfico, la base de dicha complicidad orientaba la mezcla hacia el rock entendido como referencia estilística más amplia -tanto sonora como visual-; adscripción a una escena de la que se sentían parte donde el rock en tanto referencia y “actitud” era protagonista y, por último, un formato instrumental concreto. La tradición del rock resultaba clave para la educación sentimental de los miembros del sello, y un concepto comodín para referir a la música y a la estética que proponían. En las denominadas "bios" de los artistas, en las que los miembros del sello me pidieron que trabaje, podía leerse:

-"Shaman, el músico (...) se embarca en un nuevo proyecto 'Shaman y Los Pilares de la Creación' (...) una fusión entre rasgos de música patagónica folclórica y el rock”. 
-“Catalogados por alguien como Folk-Rock-Psicótico (...) Sr. Tomate es una formación de pequeña orquesta ${ }^{166}$ desordenada y pastoral...".

-“Cómo recuperar la tradición del "rock” aquí y ahora? Más acá de las modas y las nuevas olas, en una reapropiación creativa de ciertos elementos del blues y del jazz, Casimiro Roble juega a interpretar su propia voz. Virtuosos, afinados y cuidadosos del sonido, pero también potentes, voladores y conocedores del riesgo que implica actualmente seguir haciendo 'rock'...".

-"Excursiones Polares es rock de los márgenes de la gran ciudad (...) han venido explorando una forma de canción que se abastece sin prejuicios tanto de la tradición del rock norteamericano, el pop británico, el rock argentino y hasta la canción melódica de Sandro".

[Fragmentos extraídos del Google Drive de Concepto Cero, año 2014]

¿De qué rock se trataba? Si bien el término rock resulta polisémico hasta la desesperación, hay ciertos elementos que en el caso de Concepto Cero son claramente excluidos. Hacia el interior de la escena que compartían, no se identificaban con el indie rock tal como se lo entendía en La Plata. De acuerdo a conclusiones extraídas de un trabajo anterior (Boix 2013), en La Plata suele identificarse al indie con un sonido deudor del "indie college americano, en el sentido de bandas como R.E.M., Pavement, Yo La Tengo, Pixies, Sonic Youth", como me señalaba un periodista, en una asociación que es puesta en juego a menudo y reconocida por la mayoría de los otros actores de la escena independiente local. Es decir, la afección bastante marcada por la distorsión, las capas sonoras y la desprolijidad en el audio no era del gusto de los miembros de Concepto Cero. En este sentido, Nicolás me decía: “Acá indie capaz se ubica con un sonido específico que no es al que particularmente apuntamos". Hacia el rock considerado exterior a la escena, las diferencias eran más claras: el rock no era el que Cingolani (2013) analiza en su trabajo sobre la reconfiguración pos Cromañón de los circuitos del vivo en La Plata. Las bandas que ella toma como objeto empírico - de barrios periféricos y de la localidad de Berisso, si

\footnotetext{
${ }^{166} \mathrm{Si}$ se considera la formación instrumental del grupo -guitarra acústica, bajo, batería, trompeta, armónica, guitarra eléctrica- la referencia poética a la "pequeña orquesta" se entiende por la presencia de instrumentos de cuerda, percusión y viento. No obstante, se trata de instrumentos muy presentes en la tradición del rock nacional.
} 
bien realizan muchas de sus presentaciones en el "cuadrado"-, eran conceptualizadas por mis interlocutores como "rock chabón" y generalmente invisibilizadas como parte del mundo independiente y de la tradición del rock.

Ciertos desarrollos académicos y periodísticos anclados en la ciudad de La Plata han intentado aislar rasgos propios de estilo del rock de la ciudad a partir de la controvertida idea de un "rock platense". Esta noción ha construido una relación de intimidad entre La Plata, el rock y la juventud universitaria (Jalil 2000, Rodríguez Alzueta 2005, Doeswijk y Ruiz 2007, Zabiuk 2009, Vicentini 2010, entre otros). Estos desarrollos buscan las señas de una identidad del rock local sin especificar (salvo Doeswijk y Ruiz 2007) los alcances de la categoría en cuestión, que sí son distinguidos por los músicos con los que trabajé. Avanzado el trabajo etnográfico, a mediados del año 2013, presencié un intercambio entre dos músicos de sellos de TICA Red que intentaban explicarle a Tatu Estela -productor porteño que había venido a Sonido Expansivo para dar una charla- las características de su escena:

Tatu había estado hablando de la relación entre las distintas redes sociales y su posibilidad de “delimitar escenas" (enumeró a Bandcamp, MySpace, lastfm y Taringa Música). Lautaro acota que eso es lo que hace Bandcamp con su tag "la plata"... esa etiqueta, razona, es una manera de "invocar" a las bandas de La Plata. Por lo que dice Lautaro se entiende que eso es todo el rock platense. Nicolás le contesta: "ese es el rock platense para nosotros".

De alguna manera, Nicolás le daba a entender a su amigo que dejaba mucho por fuera si quería usar dicha categoría. Pero este no era el único problema: los rasgos de estilo que son declamados en estos trabajos como característicos del "rock platense", lejos de totalizar la música joven local con inserción en las redes universitarias, se conforman más bien un vector de la diferenciación y la disputa hacia su interior. Zabiuk (2009: 78) plantea para lo que llama rock platense una "concepción del arte múltiple e integradora", que combina la música con la plástica, la escenografía, el vestuario y otras expresiones artísticas. En este mismo tono, Rodriguez Alzueta (2005) analiza el rock platense como un pop elegante y sofisticado, y Vicentini (2010: 26) sostiene su marca distintiva en la "vocación artística", vinculada a las carreras de la UNLP. Doeswijk y Ruiz (2007) abordan el rock platense de los años 90 no como una categoría geográfica de generalización - 
correspondiente a todos los artistas adscriptos al rock de la ciudad del período en cuestiónsino como una categoría de estilo a la que algunos de ellos responden, caracterizada por la impostura, la oscuridad, el kitsch, la ambigüedad, la interdisciplina y la autogestión. Como discutí en mi tesis de maestría (Boix 2013), para los músicos indies algunas características aisladas como propias del "rock platense", tales como la teatralidad y la impostura, resumían muy bien una imagen de lo que despreciaban. Por su parte, para los músicos de Concepto Cero, la categoría de rock platense se correspondía más bien al apogeo artístico de una "generación anterior" a la que podían respetar pero con la cual no se identificaban $^{167}$.

En Concepto Cero, el rock era un aire de familia que las músicas compartían pero, como sostenía Matías: "La forma de laburo también puede integrar estéticamente lo que pasa”. Matías, fanático de Spinetta y especialmente de Invisible, del jazz y de la música blues, estaba encantado con Excursiones Polares, una banda que todos en el sello asociaban a un sonido pop. De hecho, Casimiro Roble -la banda de Matías- tocó junto a Excursiones Polares en un par de fechas del sello, revelando un patrón de presentación que se repetiría en los distintos eventos propuestos y que, sin desconocer las diferencias musicales, las hacía entrar en diálogo. Sobre una de estas presentaciones, Nicolás apreciaba: “Los dos hicieron un set más acústico, y como que se valoraba mucho más la canción por sobre el resto de las cosas y quedaba súper bien”. En el año 2013, la materialización del compilado "Concepto Cero por Concepto Cero" donde de manera cruzada cada artista del sello versionaba la canción de otro extendía esta propuesta de diálogo para la producción de discos.

Sin embargo, a medida que el sello se involucraba con otros artistas, como Mariana Päraguay, el dueto Fages/Patané y Faauna, el concepto de rock comenzó a perder importancia. En febrero de 2104, Nicolás ya le indicaba a uno de los prenseros que vino a una reunión que les gustaría "correrse de la idea de un sello de rock". Al año siguiente, en mi última entrevista para esta tesis, Ángel me dijo desligándose también de la referencia del rock: "No sé, como que está medio gastado el rock como para que te sorprenda algo. Pero no sé...". En referencia a los artistas del sello explicitaba: “Como que no los elegimos por

${ }^{167}$ A fines del año 2015, se incluyó en el catálogo del sello de Mister América, una banda de "otra generación" y asociada a la categoría de "rock platense". Esto aconteció cuando ya había finalizado mi trabajo de campo por lo que no puedo establecer relaciones entre este hecho y el argumento presentado. 
un estilo musical. O no los elegimos entre sí por un estilo musical, sino por una forma de laburar, por un interés, porque son, son interesantes, son fuertes... tienen personalidad". Sin dejar de tener gravitación, el rock perdía centralidad en la definición estilística del sello ${ }^{168}$, que comenzaba a reemplazarlo por distintas nociones de lo "folclórico". En ese caso se trataba de una categoría de folclore pensada más como punto de conexión de una "línea editorial" que como referencia sonora o estética. Bajo el paraguas de este folclore podíamos encontrar a los Polares y sus “canciones folk después del fin del mundo" junto a Shaman y su folclore patagónico enhebrado por secuencias rockeras y electrónicas. Cuando Nicolás presentó esta orientación en la firma de contratos con la que di inicio a la tesis, refirió a su foco en "la canción...pero desde otro lugar de ver la canción" e inmediatamente hizo una aclaración que incluía a los dos proyectos más sonoramente rockeros del catálogo: “El PerroDiablo tomó otro rumbo...y Casimiro es un proyecto inactivo".

No obstante, a la vez que se establecían esta clase de definiciones, en los últimos meses del año 2015 el sello entraba en conversaciones con una artista de pop electrónico y con banda que cruzaba electrónica, candombe y sonidos tribales. En realidad, la propia lógica del grupo del sello era sumar todo lo que les parecía "interesante" y pasible de profesionalizarse más allá de la sonoridad, los estilos o los géneros musicales. Ángel remataba: "A mí me gusta trabajar con artistas, y que el artista que venga, que se acerque, tenga una propuesta. $\mathrm{Y}$ en esa propuesta que sea interesante, ayudarlo a desarrollarla, ¿entendés?".

A partir de la reconstrucción de todo el proceso percibí que trabajar el catálogo como si fuese el sedimento aluvional que permite dar cuenta de una concepción estética era una tentativa destinada al fracaso en la medida en que la noción de una identidad estética asociada a los parámetros provistos por la categoría de género musical -y sus nociones asociadas- ya no resultaba operativa. En su lugar encontramos una forma cambiante de procesar las concepciones estéticas, muchas veces disociada de las propias prácticas

\footnotetext{
${ }^{168}$ Este descentramiento del rock coincidía con una mayor presencia de las mujeres en el catálogo del sello. No es que Mariana Päraguay, Fages/Patané o Poli, la cantante de Sr. Tomate, no pudieran ser clasificadas dentro de lo rockero, en efecto, cualquier comentarista podría decir que tenían "actitud rockera". Sin embargo, en La Plata el del rock era un mundo marcadamente masculino y que refería a sonoridadades más tradicionalmente rockeras que las letras en francés de Päraguay o el bombo legüero de Fages/Patané. No deja de ser un dato que en mi tránsito por la escena encontré más mujeres a medida que me fui alejando de los sellos más vinculados al "rock" como valor y tradición -por ejemplo, sellos de música indie como Laptrapara ir hacia los más vinculados a la "canción", el pop y la electrónica -por ejemplo, sellos como Dice Discos y el propio Concepto Cero en su movimiento en estos años.
} 
omnívoras y desestabilizantes de estos músicos, por ejemplo en la frustración primera de Nicolás por ser "heterogéneos" y en la posterior preocupación de no poder circunscribir las distintas músicas a una estética precisa, revelada en la búsqueda de nociones articuladoras entre el rock, el folclore y la electrónica.

En el último tramo del trabajo etnográfico comencé a registrar una palabra que quizás podría indicar la clave de un nuevo modo de procesamiento: el relato. En el archivo que invoqué al comienzo del capítulo que resumía la primera reunión del año 2014, Ángel explicitaba: "Está todavía a definirse si avanzamos con el uso de una palabra, un slogan o si llegamos a la síntesis a través de una frase que permita que trabajemos con ese marco todos los aspectos de la identidad y la comunicación del sello". Al año siguiente podía leer en el capítulo de la Guía REC, escrito por Nicolás, un desarrollo que ampliaba y precisaba estas discusiones. Nicolás entendía que el relato, a desplegarse en distintos lenguajes, respondía a "sintetizar en una sola frase, potente y bien redactada, qué es lo que hacemos" (Madoery 2015: 128). Entendía que el lugar donde habita el proyecto y los hitos de su historia, los estilos e influencias musicales, eran partes constitutivas del relato. El concepto de relato hacía referencia a los valores del proyecto musical y estético que, como se señaló al comienzo del capítulo, eran objeto de la reflexión de los integrantes de Concepto Cero: lo platense, lo colectivo, lo profesional, lo comprometido eran algunos de ellos. Nicolás me dijo mientras escribía esta tesis que ellos no consideraban que su relato como sello estuviera todavía muy pulido. En particular, existía un punto que resultaba conflictivo y era el carácter platense del sello.

\section{La ciudad como mediación}

Con motivo de los cinco años del sello, mis interlocutores creían necesario un nuevo "concepto" que pudiera articular todas las acciones y eventos que se iban a realizar ese año a modo de festejo. En la reunión de enero ya mencionada, en la cual se empezó a discutir esa noción, Nicolás recuperó la de "retromanía", de Simon Reynolds: le parecía un concepto interesante porque "siempre estamos pensando que lo mejor ya pasó". De acuerdo a su perspectiva, cuando se hablaba de La Plata las referencias musicales eran siempre "La 
cofradía de la sarasa"169, Los Redondos, Virus y "nunca lo que pasa ahora". En una analogía entre la música y la ciudad, Nicolás proponía tomar de referentes visuales para los cinco años del sello construcciones de La Plata que no fueran el Pasaje Dardo Rocha o la Catedral, sino espacios no canónicos. Prácticamente no pudo terminar de desplegar su propuesta porque surgieron bastantes dudas y desencuentros en el grupo. Ángel y Anache ninguno de los cuales vive en la ciudad- decían que para ellos el sello "no es de La Plata". Nicolás y Cristo respondían que si bien el sello no parecía de La Plata -en una referencia a lo que en el pizarrón sintetizaron con la palabra "actitud"- y en efecto los artistas del sello trascendían la ciudad de La Plata -había artistas de otros centros urbanos-, sí tenía como centro de operaciones a La Plata en tanto -volviendo a la foto- "punto geográfico".

¿Qué significaba La Plata para mis interlocutores?, ¿por qué para ellos Concepto Cero no parecía en su "actitud" un sello de La Plata?, ¿cómo actuaba La Plata en tanto lugar y en tanto representación? Para responder a estas preguntas es necesario reponer dos cuestiones: el predominio de la categoría indie para referir a la escena de la cual Concepto Cero formaba parte y la particularidad de un imaginario de la ciudad yuxtapuesto a un imaginario de la música.

En cuanto a lo primero, sobrevolaba claramente a la conversación una identificación entre la ciudad y la actitud de sus sellos. Con respecto a ello, Cristóbal dijo que algunas personas de la escena con las que había hablado le habían dicho que tenían una imagen muy "seria". Cristo opuso esta seriedad al carácter "relajado" del modo de trabajo. Aunque no refirió explícitamente a ellos, todos entendimos que hablaba de otros sellos de la ciudad. Nicolás replicó: “Sí, en La Plata está toda la cuestión de 'somos amigos' y qué sé yo". Agregó que últimamente el sello había sido reconocido como una empresa, a diferencia de otros sellos musicales con los que transitaba la misma escena. Fue entonces que en relación con el profesionalismo como práctica y como valor, en oposición a las formas de trabajo "relajadas", se volvió sobre la idea de que "la amistad no es lo mismo que la jipeada". Se hicieron chistes para usarla de slogan: "Concepto Cero. Amistad no es jipeada". Todos estaban de acuerdo en renegar de la "jipeada" y en entender que esa era una característica de algunos proyectos independientes de La Plata, de los cuales querían diferenciarse y que

\footnotetext{
169 Refiere con conocimiento de causa a La cofradía de la flor solar, banda originaria de La Plata y considerada pionera para el rock local.
} 
resultaban predominantes en la representación periodística de la música joven y emergente de La Plata. Como analizo en mi tesis de maestría (Boix 2013) esta prensa construyó una novedad rockera que venía de La Plata y se asentaba en sonidos desprolijos, actitudes relajadas poco afectas al estrellato, sensibilidad barrial, culto a los amigos y despreocupación con respecto a la profesionalización ${ }^{170}$.

Los músicos y artistas con los que traté en la escena emergente, especialmente a partir de la red TICA, compartían una noción de La Plata como ciudad joven y universitaria, poniéndola a jugar en sus relatos sobre la música platense y sus diferencias con la de otras latitudes, especialmente en comparaciones con la CABA. Justamente durante un viaje de la red TICA a esta ciudad vecina pude captar con claridad este imaginario, del cual yo misma participaba: los músicos afirmaban que lo que jerarquiza a La Plata es "la movida de la gente", que a diferencia de la capital del país "todo queda cerca", además de ser una ciudad con "otra frecuencia" y "otros tiempos". Para ellos, la ciudad de La Plata se constituye en un espacio geográfico manejable y amigable, construcción afín a la propia articulación moral de su mundo musical. Esta idea que totaliza la experiencia de la ciudad en la experiencia de la escena, en una yuxtaposición de un imaginario urbano con uno musical, era replicada por el periodismo y por los analistas académicos. Una ciudad "joven” y "estudiantil” que producía un rock interdisciplinario, "artístico" y que no estaba tan expectante de triunfar en las grandes ligas -llámense firmar con una multinacional o tocar en la Ciudad de Buenos Aires. Es curioso notar cómo la representación de la ciudad, identificada con el "cuadrado" o el casco histórico, volvía invisible la periferia de la misma manera que desconocía al rock chabón como acervo rockero $^{171}$.

Pero también la ciudad en su materialidad constituía, en efecto, una mediación para la música de la escena: en su relativamente pequeño casco urbano se espacializaban las

\footnotetext{
${ }^{170}$ Un texto prácticamente fundacional de esta visión es el de Strassburguer, Juan Manuel (2008), "Llega el indie cabeza", Suplemento NO, Página/12, 5 de Junio de 2008, http://www.pagina12.com.ar/diario/suplementos/no/12-3430-2008-06-10.html.

${ }^{171}$ Esto se inscribe en lo que Segura (2015: 36) denomina "la persistencia de la forma" para representar la ciudad de la Plata. En su investigación muestra la tendencia dominante impulsada desde hace décadas por la política urbana local de ligar la ciudad con una representación gráfica: el plano fundacional. Los habitantes piensan la ciudad dentro sus límites fundacionales, una persistencia paradójica en tanto la ciudad es afectada desde hace décadas por diversos procesos de transformación urbana: conurbanización, sub-urbanización, etc. De esta manera, sintetiza el autor "las representaciones habituales de la ciudad están muy cerca del plano, del centro, de la plaza, en fin...del poder" (Segura 2015: 43).
} 
redes en las que Concepto Cero se movía -en lugares de grabación, locales de presentación en vivo, centros culturales, radios, aulas universitarias-, por lo que en la producción musical las distancias resultaban cortas y los caminos conocidos, redundando en convivencias dilatadas que terminaban por conformar lazos de amistad. De esta manera, la música de la escena era indisociable de una serie de mediaciones: la especificidad de un modo de vida estudiantil en una ciudad universitaria, los lugares de ejecución asociados a ese público prosumidor, las tecnologías digitales y su uso intensivo, los ingresos débiles compensados por los recursos familiares, pero más que nada por las comunicaciones intensas en la red de amigos. Sin embargo, a comienzos del año 2014 ya no resultaba evidente que Concepto Cero compartiera estas características: varios de los amigos se habían alejado del sello, al menos de su núcleo más dinámico; económicamente se estaban manejando otros números; ya no tenían las mismas relaciones en La Plata y se empezaban a vincular más con sellos de la CABA, incluso de amplia trayectoria.

De hecho, en el año 2015 las presentaciones de los discos de Shaman y Sr. Tomate se realizaron primero en la CABA antes que en La Plata, en una declarada búsqueda de ampliación de público. Inmediatamente estas elecciones me hicieron recordar los objetivos del sello que Nicolás declaraba en la firma de contratos del año 2014: ni "un sueño mainstream" ni "quedarse tocando en Pura Vida". En un estudio sobre la profesionalización de la carrera rapera en la ciudad norteamericana de Los Ángeles, Lee (2015) muestra de qué manera los raperos jóvenes inicialmente consideran a un espacio de presentación como un lugar para aprender y practicar habilidades, a la vez que ganarse el respeto de sus pares. No obstante, aquellos que quieren profesionalizarse y convertir al rap en una fuente de ingresos eventualmente arriban a la interpretación según la cual pasar un tiempo prolongado en ese lugar es un símbolo de no haber logrado el objetivo. En el caso que analizo, la identificación de un posible estancamiento profesional con el bar más famoso de la escena independiente de La Plata los movilizaba hacia otros lugares e incluso hacia fuera de la ciudad. En el año 2015, la mudanza de Nicolás al barrio San Telmo, si bien excedía los motivos musicales, abonaba esta interpretación: como me dijo antes de irse, La Plata había cumplido un ciclo en su vida. 


\section{Un "plan integral"}

La producción de valor estético propio implicaba no sólo la selección de un grupo de artistas con los que trabajar sino también la conformación de una performance integral que envuelve la actuación sobre el escenario, la visualidad, el tipo de espacios elegidos para los eventos y el marketing. En el capítulo anterior desarrollé la expansión de las actividades creativas del sello en lo que sus integrantes llamaban un "plan integral" para cada proyecto musical. Para introducir esta perspectiva, retomaré ahora desde un ángulo más impresionista la presentación de Shaman y los Pilares de la Creación en la sala de Caras y Caretas (2015):

Ya en la entrada se podían ver los afiches celestes que reproducían una imagen del disco y anunciaban el show. Adentro del centro cultural, lo primero que vi fue la mesa de discos, iluminada por pequeños reflectores ubicados arriba de la mesa. Anache y El Pampa que estaban en ese momento cuidando de la mesa. Fui a saludarlos. Entre los discos del sello (...) había una tablet con auriculares para escuchar "Sueño Real” subido a Youtube, disco que se podía comprar ahí mismo, además de remeras negras con la iconografía y el nombre del disco. (....). Lo veo de lejos a Nicolás de acá para allá con lo que supongo que es una planilla en la mano, también hablando por celular. (...) Las personas ingresan ordenadamente en fila. (...) En el escenario estaban los equipos y los instrumentos colocados en sus posiciones (...). Observé que el borde del escenario se encontraba una flor de papel blanca como la que aparece en la tapa del disco cubriendo los rostros de las figuras. Al costado del escenario, había un piano de cola que luego usaron para la recta final del show (...). Las butacas son cómodas (...). Apenas empezaron a tocar, en el gran telón de fondo las visuales en tonos azulados repetían motivos y proyectaban el nombre de la banda con la tipografía de la tapa del álbum. Las luces iban dialogando con las visuales que también estaban en esa línea de colores. Los músicos estaban todos vestidos de trajes negros y camisas blancas (en este sentido, más adelante me sorprendió que Sara Hebe apareciera para su parte en la canción "El viejo en la vereda" con un vestido negro y medias oscuras -siempre que la he visto en sus actuaciones está vestida de colores fuertes, diría chillones-).

A través de estas notas observamos que el lugar está señalizado por afiches con el logo del sello y la iconografía del disco, imágenes que se repiten en las visuales y la escenografía. Estos elementos, junto a las luces, envuelven de manera específica un lugar que en sí mismo no pertenece a la escena -como vimos, ni el sello ni sus sellos amigos 
contaban con lugares propios de presentación pública. La indumentaria que visten los músicos es producto de otra decisión estética, al igual que el hecho de que los músicos invitados estén vestidos en tonos oscuros. La música de Shaman -y no así la de otros artistas del sello como Faauna, para quienes el baile arriba y abajo del escenario es parte del show- permite un concierto con butacas y propone así otra relación del público con la banda, acostumbrado a verla de pie, en pequeños bares y centros culturales. Desde la perspectiva de mis interlocutores, es la reunión de todos estos elementos la que constituye un dispositivo "profesional” de presentación.

No puede llamar la atención entonces que en una reunión de TICA, cuando uno de los chicos de otro sello valoró que "si vos tenés una banda que suena bien, y tocás, lo demás es como automático" [refería a la consagración], Cristóbal y Nicolás inmediatamente gesticularon que no. Como me había dicho Nicolás al respecto de las pocas fechas que una banda del sello había tenido ese año: "[el líder del grupo] no cacha que si tiene una banda y que si es frontman [en inglés, se suele llamar así al líder], tiene que tener buen vínculo con la gente... tienen que hacer que la gente quiera ir a verlos, y tienen que generar algo más que la música, todos sabemos que él es un músico de puta madre”. Mi contacto prolongado con Concepto Cero y los criterios que construían sobre sus acciones musicales me volvieron sensible a ese "algo más" que conectaba a la música entendida a nivel sonoro. "Un buen poster, unas buenas fotos, un buen video", incluso un vestuario, eran entonces tan parte del proyecto musical, de su profesionalización y posible consagración como la música misma. Mientras algunos de sus amigos de la escena suponían que lo importante era tocar y sacar "buenos discos", Concepto Cero prestaba atención a toda una serie de objetos que enhebraban el vínculo entre el artista musical y el público, y que eran gestionados por "todo un equipo" de productores y artistas que de esta manera cobraban protagonismo casi a la par que el músico. Es verdad que la escena de La Plata se caracterizaba por su interdisciplinariedad, pero esta era más un efecto de la composición de los grupos de amigos que una estrategia consciente - aunque esta no dejara de existir. Por el contrario, Concepto Cero -junto a otros participantes de la escena- incorporaba otras manifestaciones artísticas como una decisión estética y de gestión articulada para cada proyecto musical.

Entre las estrategias que buscaban brindar "algo más” que la música, estaba la valorización del disco en tanto objeto. En una de las primeras reuniones del sello a las que 
asistí, en la que se discutía el packaging y la gráfica de "Los Ellos", Tadeo, Melina, Mariano, Cristóbal, Matías y Nicolás habían llevado distintos discos que les gustaban para evaluar tipos de formatos, tamaños, paneles, cartulinas, tintas, brillo, entre otros elementos. Este interés era muy común y a lo largo del trabajo etnográfico registré infinidad de valoraciones sobre el diseño y la materialidad de los discos de los demás. En otro ejemplo gráfico, cuando fui a la casa de Lautaro de Uf Caruf antes de un viaje a la CABA, tenía en la mesa de su cocina comedor muchísimos discos que había conseguido en los eventos pre MICA regionales. Expresó haber visto "todos los modelos de disco independiente" posibles y nos mostró a Juan -su compañero de sello- y a mí algunos de ellos. Entre ambos resaltaban la variedad que se encontraba en los diseños y evaluaban: "este me gusta por el tamaño aunque el diseño es medio grasa, no está bueno", "este diseño de imagen se parece al que hicieron los chicos [refiriendo a una banda del sello]", "uh yo quería este cartón, pero el que elegí para el mío es un poco más finito”. Para estos músicos el diseño del disco era crucial y una tarea más de la que ocuparse personalmente o en asociación con un diseñador amigo.

La importancia del disco físico en Concepto Cero y la escena emergente en general, aún en un contexto de anunciada desaparición, no puede ser subestimada. Es verdad que en ocasiones los propios músicos se preguntaban por qué editaban discos y especulaban con que quizás ya careciera de sentido. En un recuerdo de su adolescencia, un músico entrevistado me decía: "Te regalaban un disco de la banda que te gustaba y era genial, era la gloria, realmente es valorizar la música desde ese lado, desde que uno le da valor a un disco original". Por esta clase de comentarios, la valoración de los discos en la escena independiente es tomada a veces como una apuesta romántica o nostálgica. Esta valoración cobra otro sentido si entendemos cómo la edición de un disco es visualizada por los músicos como un nuevo peldaño en su trayectoria musical: lanzar discos coloca en otra posición a las bandas, especialmente en relación con la prensa que ahora puede "levantar" el lanzamiento. Esta misma lógica asiste al proceso en el que, a largo del período etnográfico, en Concepto Cero los discos pasaron de ser multicopiados de manera hogareña, aunque en ediciones en "cajita de cartón" -técnicamente digipack-, a ser 
replicados de forma industrial ${ }^{172}$. Acompañando esta evolución, mejoraron en diseño y muchos incorporaron ediciones "de luxe": por ejemplo, "Hilario" de Mariana Päraguay salió en una edición limitada envuelto en una bolsa bordada artesanalmente, postales y un kit de bordado.

El disco funciona como una carta de presentación con actores considerados aliados y estratégicos para la profesionalización. En este sentido, los intercambios y regalos de discos eran regulares: a las capacitaciones de Recalculando las bandas siempre llevaban discos para dejarle al responsable de la charla. Esta escena se repitió a lo largo del trabajo de campo en las actividades del pre MICA y el MICA, en las conferencias de BAFIM, en las reuniones en el Instituto Cultural y en otros espacios. Llevar discos consigo a estos eventos era prácticamente obligatorio y regalarlos al funcionario, al periodista o al promotor era no sólo un presente, sino una actividad central en la visibilización y difusión del proyecto. Esta no se saldaba con la presencia del disco en la web: la sobre-oferta de producciones musicales en Internet exigía tomar otras estrategias.

Pero en el caso de Concepto Cero los discos no eran los únicos objetos que se producían, y podía suceder que no fueran los que más se vendían. En efecto, durante el trabajo etnográfico, constaté cómo los miembros de Concepto Cero buscaban qué otras cosas vender: remeras, calcomanías, postales, entre otros objetos que le otorgaban mayor protagonismo a los diseñadores, fotógrafos y demás artistas visuales de la red. Una noche en la sede platense de La Trastienda donde tocaron El Perrodiablo, La Patrulla Espacial y Casimiro Roble me hice cargo de la "feria de discos", donde se vendieron más remeras que productos discográficos.

Tanto como los discos, estos objetos materializaban y dejaban testimonio físico de los proyectos musicales. Cuando conocí a Nicolás y lo indagué acerca de su sello se excusó de que en ese momento no tenía discos para mostrarme y me regaló un elegante sobre de plástico transparente que contenía tarjetas en cartulina del ciclo en el hostel Frankville -en las que se apreciaban dibujos de Tadeo a todo color-; un folleto fotocopiado en papel amarillo que en un formato libro enumeraba las actividades del sello y los distintos artistas

\footnotetext{
${ }^{172}$ Esta valoración del disco físico no resulta contradictoria con la idea expuesta previamente acerca de la relativización del carácter discográfico en los sellos musicales como el estudiado: sólo es menos central en comparación a la mucho más abarcadora sociabilidad musical y estética del grupo de amigos que gestiona el sello y en relación con la notable preponderancia que adquiere en esta disposición musical el tocar en vivo -y no sólo porque el vivo otorga, según se da por hecho en el ambiente, gran parte de las entradas monetarias.
} 
-divididos en las categorías "músicos", "artistas visuales", "fotógrafos" y "Djs"-; una postal del lanzamiento del primer disco de Casimiro Roble, "Volumen 1"; una tarjeta de "Los Ellos" - aunque todavía el disco no hubiera salido- y calcomanías del sello. Fue un anuncio de la importancia que tendrían estos objetos para Concepto Cero: mis notas de campo se poblaron de referencias a ellos.

Tarjetas, folletos, fotos, calcomanías, postales, remeras, visuales, lonas -a las que indistintamente también llamaban banners- siempre tenían lugar en las conversaciones y en los eventos. Estos objetos se correspondían a la llamada "parte gráfica y visual" del sello y resultaban estratégicos para la construcción de una "identidad visual". Un músico de otro sello me comentaba que "Concepto Cero fue de los primeros sellos en La Plata [refiere a los últimos cinco años] que tenían los flyers impresos... también que pusieron Vjs". Generalmente, en las reuniones, los diseñadores trabajaban a partir de un "concepto" articulador que luego podía remitirse tanto en un flyer, en un video, una foto, entre otros soportes. Dada esta centralidad, en cada evento del sello al que asistía me llevaba algo, aunque más no fuera una tarjeta. Fue así que durante el período de investigación completé una caja con distintos recuerdos relativos al sello, a pesar de que todavía no había caído en la cuenta de que estos eran partes plenas del proyecto musical.

El stock disponible de estos distintos objetos y su traslado entre las casas de los distintos miembros y entre estas y los eventos, así como el diseño gráfico y los costos que implicaba realizar tiradas nuevas eran temas recurrentes. Realizar gastos en estos objetos era considerado una inversión incluso cuando no se tenían recursos. En este sentido, en un registro de mediados del año 2011, anoté:

Se habían acabado unos folletos/tarjetas a nombre del sello y se necesitaban más para distintos eventos. Matías y Nicolás ponían sobre la mesa si hacerlas o no por una cuestión de presupuesto, ya que se venían las cancelaciones del disco [Los Ellos]. Las últimas que habían hecho las habían impreso en un papel que había comprado Tadeo a muy poca plata en liquidación (él recordó que lo había comprado en un lugar un tanto oculto de La Plata y le dijo "dámelo todo" a quien lo atendió). Nicolás le preguntó a Tadeo cómo se podían hacer unas tarjetas baratas, más "de batalla", mientras este pensaba dónde conseguir papeles baratos.

$(\ldots)$ 
Cristóbal planteó que era necesario armar o encargar una lona más grande [con el logo de Concepto Cero] (...) porque el otro día [en un evento en el CC Islas Malvinas] la lona tenía que señalizar la carpa [donde estaba Le Villera, la Dj del sello] y algunas personas no habían visto el cartel. Nicolás puso de ejemplo la "presencia" que tenían las lonas oficiales del Fesaalp.

Estos objetos que se ponían en circulación en conexión con la música en un nivel sonoro no tenían solamente un valor representacional, a la manera de vehículos de las ideas estéticas que el grupo quería transmitir, sino que resultaban parte constitutiva de la propuesta, en tanto se constituyen en sus medios de fijación y producen una "presencia" específica en la que el grupo esperaba ser reconocido en una identidad "fuerte" y en su "profesionalismo". De esta forma, estos registros tomados en los escenarios de la performance musical y de la vida grupal de mis interlocutores en Concepto Cero, a la vez que la forma en que ellos mismos lo conceptualizaban, me permiten volver al problema de la profesionalización en este mundo musical a partir de la noción de su multidimensionalidad: el carácter profesional de la música era conformado por el trabajo en las numerosas instancias por las que esta emerge, en lugar de ser definido en una sola de ellas. Los objetos, recursos y materiales que fui presentando, entramados en un entorno que hacía a la música como tal, eran parte integrante de dicho proceso ${ }^{173}$.

\section{La pregunta por lo nuevo}

Empecé este capítulo refiriendo al ejercicio de la reflexividad que mis interlocutores ponían en práctica sobre su propia práctica musical. Un tópico central de reflexión era el carácter de novedad que revestía a las organizaciones, las trayectorias y los proyectos musicales. Esto era un tema del espacio reservado en el blog del sello para escribir sobre sus inquietudes musicales. Todos estábamos invitados a escribir, de hecho, a mí se me insistió bastante para que lo hiciera. Sin embargo, el que posteaba generalmente allí era Nicolás. Esta sección llamada "Detrás del cero" recopila al día de hoy distintos post que presentan libros -Música para Camaleones-, videoclips y documentales musicales -por

\footnotetext{
${ }^{173}$ Aún cuando en esta tesis mi análisis no asiste a todas las dimensiones de este entorno del proyecto musical, este no es secundario sino parte constitutiva de la música.
} 
ejemplo, el proceso creativo en artistas como Björk, y Napster: "la plataforma que dio comienzo a las plataformas peer to peer de transferencias de archivos" ${ }^{174}$-, además de reflexiones sobre el estado actual de la música. En estos post, Nicolás refería con regularidad a las "nuevas tecnologías", a los "nuevos modelos" o a una "nueva instancia de la cultura”. La novedad nunca aparecía referida a la estética, pero no era este un discurso que diferenciara a Concepto Cero de otros actores de su mundo musical. En efecto, una mirada detenida en los programas del MICA a los que asistieron los miembros de Concepto Cero nos revela lo mismo que una escucha atenta a las capacitaciones de Recalculando o a las conferencias del Instituto Cultural: "el modelo de negocio", “el paradigma del músico", “el modelo de sello" eran los objetos a los que se adjetivaba como "nuevos". En contraste, y quizás como prueba sintomática de esta situación, cuando escuchábamos música realizábamos juicios estéticos que remitían una y otra vez a las influencias sin considerar la innovación como un valor estético.

Las "novedades" venían generalmente de la mano de las "nuevas tecnologías". En el discurso del periodista Fábregat al que referí en el capítulo III, tanto la posibilidad de que cada artista "lleve el negocio" como la muerte del modelo de la "varita mágica" se asocian con las nuevas tecnologías -y la crisis de la industria. Cuando Seba presentaba en una capacitación de Recalculando la técnica del streaming la relacionaba con el futuro de la industria musical y con las nuevas generaciones, tal como puede leerse en mi diario etnográfico:

Refiriéndose a la visualización de videos en streaming dijo: "yo no soy de esa generación, no lo consumo", pero sí dijo saber que esto era lo que se consumía y "lo que va ahora” y más "dentro de unos años". Luego trajo a colación las palabras de un amigo, el manager de Pez, que le dijo "boludo, no te das cuenta que la gente escucha música en You Tube". Luego buscó un efecto tragicómico al decir: "hoy es mi cumpleaños, me compré un montón de discos, en mi vida compré un montón de discos, ¿dónde los voy a escuchar?", teniendo en cuenta, agregó, que ya "las nuevas computadoras no vienen con reproductor de CD”.

174 En: "Detrás del cero", posteo del 15 de noviembre de 2015. Disponible en la web: http://conceptocero.com/tipo/detras-del-cero/ 
La idea de una nueva generación con otros valores y formas de organizarse solía acompañar estas reflexiones, en especial en comparaciones con la década del 90. Al respecto de la gestión por los propios artistas, Martín consideraba en una capacitación que ya no "estila más eso de esta data es mía y no te la paso", una idea que, evaluaba, "ya no es de esta generación, las cosas ya no se hacen más así”. A diferencia de Martín, muchos de mis interlocutores habían sido apenas unos niños en esa época, pero también afirmaban contrastes con los años 90. Con motivo de la inclusión de una nueva banda por parte de un sello amigo, algunos miembros de Concepto Cero se preguntaban la razón, dado que "es una banda que se maneja como en los noventa". Esta acusación suponía divismo e individualismo por parte de los miembros de esa banda, inconsistente con el trabajo en equipo del sello amigo. Es cierto que este tipo de comparaciones podrían resultar un tanto autocomplacientes pero no por ese motivo dejaban de revelar la convicción de una novedad de las propias prácticas musicales, a nivel de la producción y la gestión musical.

La pregunta por la novedad estética que no se hacían mis interlocutores sí se la plantearon algunos análisis contemporáneos a la investigación realizada. Alabarces et. al. (2008: 42) afirmaban hace unos años que en materia de rock argentino últimamente "nadie inventa nada nuevo", refiriendo a un "desierto estético" que atravesaba las clases sociales y los géneros musicales. Estos analistas esperaban que la innovación fuera estética y se produjera bajo el formato de las bandas que partirían de "los garages y las salas de todas las ciudades argentinas de mediano y gran porte" y que luego, presumiblemente, llegarían a cruzarse con ellos en las tiendas de discos, a juzgar por el resto de los reconocidos artistas que nombran en su artículo. Si bien plantean que su afirmación no es legitimista, ya que el desierto es transclasista, cabe preguntarse: ¿desde qué lugar, desde que supuestos socialmente construidos sobre la innovación, se proclama la falta de novedades en la música rock? Construyendo una imagen de un relativismo ingenuo, estos autores sostienen que la "renuncia al juicio y la evaluación" estéticas por parte del investigador se identifica con un "relativismo falaz, y como tal puro populismo, estético pero a la vez político" (Alabarces et. al. 2008: 58).

Sin embargo, debe discutirse el parámetro no relativizado de la innovación con el que este trabajo mide el campo de la música actual, uno asociado a un paradigma estético vanguardista, donde lo nuevo es lo que rompe con las formas anteriores. Como plantea 
López Cano (2011) en una intervención al respecto de la necesidad de desnaturalizar la supuesta inevitabilidad de los juicios de valor sobre la música, el juicio musical es siempre un proceso social y sus términos no derivan de "la música en sí misma", sino de las instituciones y discursos específicos que en ese acto también la producen. Esto debería alertar acerca de que juicios al respecto de la calidad o innovación estética de la música colaboran a la construcción y perpetuación de un canon legítimo -el que sanciona acerca de la "verdadera" estética - que regula la valoración de los productos y prácticas musicales de una comunidad. Por lo tanto, los juicios de valor deben ser concienciados en el discurso académico, deben ser tomados como objeto de investigación, una de las maneras en que los juicios de valor pueden producir conocimiento. La posición de López Cano no representa un relativismo ramplón, sino una postura reflexionada que descentra y desnaturaliza la propensión estética del investigador, logrando una implantación y una legitimidad en los estudios sociales de la música.

En este contexto, una pregunta sociológica por lo nuevo no puede partir del supuesto no analizado de que el criterio estético es también sociológico. Una pregunta por la innovación en esos términos pierde de vista el dato fundamental de la escala de estos mundos musicales y la relación de estos jóvenes con los medios de producción de música y con la música misma. En otras palabras, un interrogante así presupone un paradigma de relaciones con la música que ha comenzado a declinar mientras emerge una configuración alternativa. Y lo que se pierde de captar es esa misma emergencia.

Reynolds (2012) describe un elemento fundamental de ese escenario emergente no considerado en la crítica de Alabarces et. al. (2008). Las nuevas generaciones se enfrentan a una experiencia del infinito a través del gran archivo de músicas globales que se ha habilitado gracias a Internet, una situación en la que -de acuerdo a Reynolds- es difícil y poco probable producir estéticas originales. El archivo infinito es la condición de la "retromanía", término con el que refiere a una producción musical que mixtura lúdicamente referencias a músicas pasadas, sin experimentar la otrora bien ponderada "angustia de las influencias" o "el pathos de haber llegado tarde" (Reynolds 2012: 428). El crítico musical analiza esta música "nueva" convirtiendo en guía del análisis a los criterios estéticos que adjudica a los años 60 en tanto década dorada de la música pop. De acuerdo a su lectura, la década del 60 estableció que el continuo cambio y la novedad debería ser el motor de 
desarrollo del rock y el pop. Frente al panorama, se lamenta de que los primeros diez años del nuevo siglo podrían estar destinados a ser la primera década de música pop que la historia recordará por su tecnología musical antes que por la música misma. Sin considerar seriamente que estos criterios quizás puedan determinar la novedad para los músicos, expresa que "descifrar qué podría definir a esta etapa como una era esencialmente distinta de otras es un esfuerzo titánico" (Reynolds 2012: 415).

Como desarrollé en las páginas anteriores, los esfuerzos de interpretación de los propios músicos hacían hincapié en esa configuración alternativa donde las nuevas tecnologías son centrales. A lo largo de los capítulos de esta tesis acompañé a un grupo de artistas producir música, trazar sus trayectorias, plantearse la profesionalización y obtener cierto éxito de un modo en cierto sentido diferenciado de las bandas de décadas anteriores. Su concepción de la novedad ya no descansaba en las rupturas estéticas radicales. Frente a ellos, mientras no se relativice este parámetro de apreciación de la innovación, nuestras lecturas serán decadentistas.

Este parámetro de originalidad, asociado al aura de individualidad y creatividad del autor, no es una invención propia del pop, sino que es en gran parte heredado del vanguardismo en tanto patrón estético -cuestión que desde ya Reynolds no ignora pero prácticamente no menciona. Así, este criterio de originalidad que se presenta universal no es más que singular y propio de un arte bien determinado. No obstante, existen otros criterios de producción y apreciación musical donde la originalidad se reformula y a los fines de mi interés -y me atrevo decir del de Reynolds-, los que aparecen por mediación de las nuevas tecnologías son los más importantes. El trabajo de Irisarri (2011) realizado en un colectivo de Djs de la CABA para quienes el sampler, el mash up y el remix se hallan en el corazón de su práctica musical, muestra esto con claridad. Para los integrantes del colectivo, sus producciones deben su propiedad "original" a la apelación a la "sorpresa" a través de la combinación de elementos musicales antes incombinables. Es decir, es en la mezcla incongruente con los sistemas de clasificación dominantes donde radica lo original y no en el hecho de ser composiciones que nunca existieron antes. Es así que, desde la perspectiva de estos músicos, "la ecuación reciclado igual a no original no es falsa sino irrelevante, pues desde su punto de vista es el uso lo que torna original el producto" (Gallo y Semán 2012: 156). Estos criterios no son extraordinarios y podemos encontrarlos 
diseminados en Concepto Cero y sus amigos: la originalidad estética no es tan importante cuando se "tiene algo para decir", cuando "los proyectos son fuertes y con personalidad" y cuando el músico puede hablar a su público "más allá de la música".

Para esta investigación, el seguimiento de la relación reflexiva y crítica que mis interlocutores tendían con la música permitió pensar que la novedad que los analistas buscaban se podía entender en los términos de un vínculo con la música que atraviesa los géneros musicales más que posarse en uno de ellos, perfilado como nuevo. Si esto es así, como bien anotan Gallo y Semán (en prensa): “a los géneros musicales no les sucede un nuevo género sino una nueva forma de producir y usar la música, una nueva relación con los medios de producción de música que por esa misma variación tampoco es la misma música de siempre". Para tranquilidad de Reynolds, las tecnologías musicales no son lo único que en un futuro podrá ser recordado. Estas han habilitado (siguiendo a De Nora 2000) un proceso que las excede: una pluralización de la producción musical, de las relaciones sociales que ella habilita, de las categorías que se utilizan para evaluarla y de las posibilidades de trabajo y de trayectorias profesionales en la música. 


\section{Reflexiones finales}

En esta etnografía relaté una historia que remite a un problema: el de instituir y profesionalizar entre amigos y pares un sello donde se produce y gestiona música. El nombre "sello", con el que los músicos a los que seguí nombran a su emprendimiento, remite a un fenómeno harto conocido y expandido en la industria musical: el del sello discográfico. Aún así, lo que encontré tras la palabra "sello" en Concepto Cero, foco empírico de esta tesis, desbordaba un patrón de producción de fonogramas, una lógica de funcionamiento a partir de los géneros musicales como sectores de mercado y unos rendimientos económicos medidos exclusivamente en términos empresariales. En Concepto Cero descubrí, por el contrario, la ampliación de las actividades creativas que hacen emerger la música, la búsqueda de un relato que identificara al sello no sólo desde los estilos musicales y una forma de producir música que, si bien podía inspirarse en las empresas, funcionaba a partir de una red regulada por la noción de sustentabilidad económica. Esta historia fue protagonizada por músicos que, en coincidencia con miles de sus colegas en todo el país, se propusieron no sólo tocar sino hacerse cargo de la gestión de su propia obra. Al seguir el trayecto singular que los integrantes de Concepto Cero trazaron para aplicarse a ese objetivo -en el que sus acciones musicales desestabilizantes coincidieron con una transformación de la industria y un desdoblamiento de las escenas musicales-, fui partícipe del proceso en el que profesionalizaron su sello a la vez que produjeron perfiles profesionales y opciones laborales que no estaban dados de antemano.

Concepto Cero, como la mayoría de los emprendimientos musicales emergentes de La Plata, había sido creado por un grupo de amigos con el objetivo de editar sus propios materiales musicales. Habían llamado a este emprendimiento "sello", aunque no dejaban de dudar de la precisión de esta denominación cuando comparaban su actividad con la de un sello discográfico. Fuera de la escena, no resultaba tan claro qué era y cómo operaba un sello musical de esta clase: especialmente al comienzo del trabajo etnográfico, era usual escuchar por parte de los integrantes de Concepto Cero la anécdota de bandas y solistas que les escribían para editar su álbum, como si trataran con un sello discográfico tradicional. En 
el transcurso de la etnografía, estas propuestas se tornaron más visibles y empezaron a ser relevadas por la prensa de rock y de cultura juvenil. En este relevamiento, el Estado, a partir de la política pública Recalculando, tuvo un papel central al otorgarle a estas redes de producción musical una entidad que reconocía su diferencia con los sellos discográficos tradicionales. La conceptualización de estos emprendimientos como sellos de gestión colectiva, en una descripción en buena medida coincidente con los hallazgos de mi tesis de maestría, era una manifestación del alto grado de reflexividad con el que operaban estos músicos. Pero también del interés de jerarquizar a unos emprendimientos que otros actores del campo insistían en leer desde el discográfico-centrismo. Con respecto a este punto, la posición de la UMI, que clasifica en el mismo grupo a sellos de amigos con sellos de carácter empresario, es sólo un ejemplo. La resemantización en la práctica que estos músicos de La Plata, y también sus colegas de otras partes del país, habían hecho del sello discográfico nos advierte sobre una transformación en el mundo de la música que puede escapar a la consideración si nos dejamos llevar por falsas sinonimias.

Los miembros de Concepto Cero, y también los de sus sellos amigos, consideraban al músico que se limitaba a sus funciones de ejecutante y compositor como un personaje que ya no tenía lugar en un mundo de la música transformado por las nuevas tecnologías. A lo largo de la tesis mostré cómo el músico tenía que "ser su propio promotor", "tener control sobre su música", "trabajar para las otras bandas" y "saber trabajar en red y en equipo". La gestión se volvía así una parte constitutiva de las habilidades del músico. Las acusaciones vertidas en el diálogo con otra generación, especialmente la de los años 90, contribuían a precisar los rasgos de esta nueva figura. Contra el individualismo y la vida desordenada de las "reinas" y "las estrellas de rock" -que solían llegar tarde a los eventos organizados por el sello, no cooperar en la organización de las fechas y actuar como si esperaran el toque de la "varita mágica"-, se posicionaba un artista que había ampliado las dimensiones de la música en las que se veía comprometido. Esta nueva figura combinaba las horas en la práctica del instrumento y las performances en el escenario con las planillas de Excel y las capacitaciones ofrecidas por distintas instituciones. Las características del modelo resultaban más claras que su interpretación: una vez establecida la distancia con una visión romántica del artista, ¿los músicos se volvían trabajadores o gestores especializados de su arte? 
Más allá de estas diferencias, la alta aceptación que tenía esta concepción del músico al interior de la escena en la que transité junto a Concepto Cero se revela en que aun quienes eran acusados de "reinas" y "estrellas" reconocían la centralidad que adquiría la gestión en la propia actividad del músico; aun cuando según otros no la practicaran. Para la mayoría de los músicos con los que traté, esta manera de relacionarse con el mercado y otras instancias que median con recursos era una verdadera obligación, a la vez que una novedad que diferenciaba a su "generación" de las previas. Los trabajos que retoman en este punto la posición de la UMI, una institución cuyos lineamientos eran muchas veces criticados, al tiempo que sus líderes identificados con una generación anterior, coinciden con esta idea y refuerzan la importancia que otorgué en este trabajo a la gestión musical. Esta figura de músico emergente precisa ser contrastada con las características de otros momentos de la música juvenil, lo que apunta un tema a la agenda de la historia y la sociología de la música.

Como había afirmado Eduardo Fábregat, el periodista de rock del diario Página/12 que participó de las capacitaciones de Recalculando, en el mundo de la música "la varita mágica se terminó". Mis interlocutores en Concepto Cero acordaban con él y la investigación realizada refuerza esta interpretación. No obstante, todos también podíamos observar cómo la lógica de la "varita" no dejaba de operar en las reformulaciones que "la industria" ensayaba para captar el incipiente y cada vez más visible mercado de los sellos musicales como Concepto Cero. El caso de Geiser, con el que bromeaban los integrantes de Excursiones Polares -tal como narré en la introducción de esta tesis-, mostraba esto con claridad: un sub sello de una gran empresa de música y entretenimiento local (Pop Art) que reclutaba artistas con cierta trayectoria en el mundo emergente. Bajo esta lógica, bandas y solistas que dieron sus primeros pasos en sellos de amigos forman actualmente parte de su catálogo. En este contexto, defender el "modelo" de un sello gestionado entre pares y la expertise del músico para gestionar -como hizo Nicolás en la conferencia de BAFIM, según mostré en el inicio del capítulo IV- implicaba cuestionar los modelos de otros sellos y la creencia según la cual "no hay nada peor que un músico que es un manager".

A lo largo del proceso que relaté en la tesis, Concepto Cero pudo reclutar entre sus redes a otros artistas más allá del núcleo original de amigos y proponerse acciones 
musicales más riesgosas que implicaban no "quedar(se) tocando para veinte tipos" ni para los "amigos de siempre". Mientras la mayoría de los sellos gestionados por amigos les decían "vos te a vas a editar" a los aspirantes a formar parte de sus redes -la opción que Shaman sintetizaba en la idea "soy mi propio sello"-, Concepto Cero se embarcó en un proceso que resultó en una configuración diferente. En un primer momento, se propuso ampliar las "conexiones" y se hizo tanto de nuevos amigos que estaban "en la misma" como de aliados de quienes podía obtener recursos, entre los cuales se destacaron ciertos programas y funcionarios estatales. Para los miembros de Concepto Cero, la profesionalización -que también se incentivaba desde el estado- era un proceso que permitiría el funcionamiento de los proyectos más allá de la condición efímera e inestable extendida en la escena emergente, que dificultaba "armar un equipo" y sostener las apuestas en el tiempo. La presencia del estado en estas redes me mostró las adhesiones variables y discutidas que tenía su intervención, así como la reformulación del valor independiente de la música. En este contexto, la independencia podía ser un punto de partida en el estudio de estos temas pero no un punto de llegada: en sí misma, no delimitaba un sector musical específico ni un conjunto de prácticas en particular. Ni siquiera unos actores determinados.

En estas redes, no todos los amigos que Concepto Cero hizo en su tránsito por la escena producían y gestionaban música de la misma manera. Hacia el final del proceso investigado, el sello era asociado en un aire de familia a una empresa, a diferencia de otros sellos de la escena. Sus integrantes confirmaban allí una diferencia que era el resultado de trabajar entre amigos pero nunca entre "jipis", oposición que sintetizaba el vector de la crítica que realizaban a la escena platense. Esta acusación de jipismo volvía a enfatizar tanto el protagonismo de un artista multitareas y emprendedor como la necesidad de organizar el trabajo, especializar las tareas y acotar la toma de decisiones a un núcleo acotado. La música se podía seguir gestionando entre amigos -eso eran Nicolás y Ángel, responsables y socios del sello al final de mi investigación- pero en los términos de un compromiso profesional diferente.

En el mismo proceso, algunos integrantes del sello habían desarrollado competencias y especializaciones que los convertían en verdaderos expertos en organización de eventos, producción de discos, gestión de redes sociales y otras tareas que, en el contexto de la expansión económica de las denominadas industrias creativas, 
comenzaban a ser valoradas por fuera del sello y de la escena en que se inscribía. En la generación anterior de músicos platenses, a la que traté en mi investigación de maestría (2009-2011), el trabajo de los músicos en otras áreas de la actividad económica permitía unos trayectos en la música bajo la lógica de la complementariedad. Por el contrario, para los de Concepto Cero el trabajo era el que acontecía en la música, entendida como entramado de una multiplicidad de instancias que no sólo excedían el tocar -cosa que ya ocurría con sus predecesores- sino que habían sido ampliadas a partir del proceso de profesionalización. Es en este contexto novedoso que Nicolás podía decir que los músicos "tienen que ponerle diez horas todos los días a lo que hacen", lo que suponía una dedicación full time con la que no todos contaban. Ese "estar en la música" era una manera de vivir y trabajar en la que la mayor parte del tiempo el músico trataba con materiales musicales, interactuaba con otros artistas, tocaba su propia música y obtenía sus medios de vida a partir de la combinación de todas esas instancias. Es verdad que en la sociología y antropología de la música no es novedad considerar el arte como un trabajo -quizás desde la sencilla y a la vez plena de consecuencias premisa de H. Becker. Pero si el arte es un trabajo y una profesión, ¿en qué sentido lo es? Mis interlocutores tenían formas de conciencia específicas acerca de cómo era dicho trabajo profesional y cómo debería ser. Seguirlos desvió mis energías de la discusión de la denuncia de la explotación velada del trabajo artístico para comprender la ambigüedad que este presenta frente a una sociología del trabajo centrada en las experiencias del empleo protegido y articulador de una carrera. Por otro lado, al considerar este trabajo como parte plena de un sistema de mediaciones en el que la música surgía, pude descubrir todo lo que esas actividades suponían más allá del problema del empleo.

Algunos de los músicos con los que Concepto Cero compartía redes, sospechaban que este vínculo con la música se predisponía a amar más el dinero que el arte. A estos músicos gestores, se preguntaban: “¿les gustaba más la música o la gestión?”. ¿No eran, en definitiva, nuevos managers? El interrogante actualizaba la oposición entre el arte y el comercio sin dar lugar a la consideración de que para los protagonistas de esta tesis la gestión ya no se separaba de la música. Para estos últimos, la ponderada creatividad en el arte se encontraba también en la manera en que se elegía un emplazamiento para un evento o se interactuaba con los fabricantes de un packaging. De esta manera, Nicolás, Ángel y 
otros miembros del sello resignificaban las tareas de management, de producción y de gestión como actividades creativas. Al reflexionar sobre su manera de vincularse con las distintas instancias que hacían surgir la música, huían de las categorías de profesión de amplia circulación, como manager, productor y empresario de la música. De esta manera, mis interlocutores me alertaban de no caer en la tentación de subsumir sus prácticas a identidades profesionales previas que podían incluso tener el mismo nombre, pero habían surgido de un sistema de relaciones estéticas donde los vínculos posibles con la música eran otros.

En su búsqueda por "ser profesionales", los integrantes de Concepto Cero habían logrado desarrollar una propuesta que aseguraba "algo más que la música". Ese "algo más", más allá de la separación que pueda connotar la expresión, era parte constitutiva de la experiencia musical que el sello proponía. A partir de sus conexiones en el mundo más amplio de la producción cultural y de la composición de un grupo que sumaba diseñadores, Vjs, Djs, fotógrafos, productores y gestores que se iban especializando, el sello producía una forma integral de habitar el proyecto musical. Por limitaciones de tiempo, ese "algo más" no es desplegado en esta tesis tanto como exige su centralidad. No obstante, intenté tenerlo en cuenta en todo momento: el vestuario, los banners, las postales, los carteles, las luces, aparecen una y otra vez a lo largo de estas páginas.

Si algo disputaban los músicos de la generación de Concepto Cero con los de generaciones anteriores, esto era el estatuto mismo del músico y el sentido de unas organizaciones productoras de música que implicaban una lógica de trabajo en red y entre sujetos considerados pares. En este sentido, el conflicto principal no era estético, tradicional lenguaje en el que una fracción heterodoxa o una nueva generación alteriza con los ya establecidos. Esto, sin embargo, no significa que las disputas estéticas no existieran: en el "aburrimiento" que los sellos de género le producían a algunos miembros de Concepto Cero y en la forma en que creían que el rock se erosionaba como estilo es posible leer la desestabilización de los criterios con los que otros organizaban sus prácticas estéticas. De la misma manera, en la búsqueda de una "línea editorial” que cobijara a los distintos artistas y que en pocos años se desplazaba hacia una específica noción de "relato", la práctica de Concepto Cero volvía a priorizar la organización social y sus mediaciones (la visualidad de las performances, la materialidad de los discos, la singularidad de un emplazamiento 
urbano, el compromiso de una forma de trabajo, etc.) por sobre la estética estrictamente sonora. Si es posible decirlo de este modo, al término del período etnográfico la disputa estética de Concepto Cero se aplicaba a visibilizar las múltiples determinaciones de su propia estética más que a construir una línea estética. Tentativas de esta clase deberían advertir a las aproximaciones analíticas sobre la producción musical que colocan a priori un concepto universal de estética en un lugar central. Asimismo, cuestionar la persistencia en el análisis de paradigmas no relativizados de apreciación musical, del que se derivan juicios de valor sobre la música que quizás no sean precisamente los que esta elige para medirse a sí misma.

Esta historia se podría haber contado de otra manera. O más bien: se podría haber sistematizado. Si hubiera observado la música como un objeto dado, la habría definido a partir de unas características estéticas, públicos específicos, determinadas clases sociales, ciertos recursos tecnológicos $\mathrm{y}$, con suerte, un emplazamiento físico. Podría pensarse, con razón, que esos elementos están presentes en esta tesis. Lo están, pero su mera enumeración no define con precisión lo que efectivamente creo haber hecho. Intenté reconfigurar la música en una red y atender a su surgimiento a partir de la multiplicación de los elementos, al menos más de los que usualmente suelen aceptarse en sociología. Si la música no era un objeto sino una mediación, y si las mediaciones no estaban dadas de una vez sino que se desplegaban y transformaban en el transcurso de la investigación, la respuesta fue escribir una narrativa de las mediaciones. Repuse entonces la historia en la cual unos actores, una sociabilidad estética, una relación con los géneros musicales, una relación con las nuevas tecnologías, unas formas de instituir y habitar el sello musical, una concepción de la profesión y del trabajo en la música, unas ideas sobre las generaciones precedentes, una noción de la gestión, un vínculo con otras disciplinas estéticas, entre otros elementos, se conjugaban de manera singular. Bien pensado, eso mismo querían hacer mis interlocutores: definir su música a partir de un relato y no bajo el peso de una categoría.

Mi relato, como ya dije, es el resultado de una etnografía. Sin embargo, no siempre la perspectiva etnográfica da lugar a una historia, ni tiene por qué hacerlo. Toda vez que se aplica el método etnográfico emerge una versión propia de la etnografía, resultado del encuentro entre dos singularidades: la del etnógrafo y la de la configuración que analiza. Hay razones muy precisas que llevaron a mi etnografía a construirse como un relato. Para 
empezar, resultó determinante la atención que mis interlocutores prestaban a la historicidad de sus prácticas: sus narrativas acerca de las diferencias con una "generación anterior", sus comparaciones acerca de lo que hasta hace pocos años era de una manera y ahora de otra, sus referencias a lo que era una "novedad" en oposición lo que ya no ofrecía "nada nuevo". En otras palabras, la configuración analizada se estaba armando de su propia historia: la de su novedad y su diferencia. Este interés se conjugó con mi propia trayectoria como investigadora que había analizado un estilo musical y un momento previo de los sellos musicales en La Plata. Todo esto acontecía mientras seguía un proceso dinámico y cuyo estado se encontraba históricamente abierto. Fue en ese proceso que dialogué con los protagonistas de esta tesis, por lo que la construcción etnográfica trata de captar las reformulaciones a las que son sometidos conceptos y momentos clave de esta configuración, tales como "sello musical", "amigos", "músico", "gestor", "profesión" y, claro, "música". De esta manera, tanto la lógica del fenómeno analizado como la de la orientación teórica con la que acompañé su devenir, me conducían hacia la historia.

Mi encuentro con Concepto Cero me llevó a extremar el aspecto dialógico de la etnografía. Primero, porque los músicos y artistas con los que investigué estaban tan interesados como yo en los cambios en el mundo de la música y en el significado que tenían. Al término de mi trabajo de campo me interrogaba: ¿Concepto Cero puede conceptualizarse aún como un sello de gestión colectiva? ¿Se convirtió en una empresa? ¿Todavía es "independiente"? Creo que a esta altura resulta evidente que no era yo la única que preguntaba. Si mi respuesta siguió la de mis interlocutores, no fue por pereza intelectual o falta de ejercicio de la imaginación sociológica, sino porque para una ciencia social empírica no es el analista el que puede resolver - probablemente por obra y gracia de la sobre-interpretación- lo que no han cerrado los propios actores.

Las proposiciones derivadas de la sociología de las mediaciones, que no dependen del cierre o apertura de la configuración, terminaron de dar forma a una orientación etnográfica preocupada por no recaer en ninguno de los dos polos de interpretación reduccionista de la relación entre la música y la sociedad, el esteticismo y el sociologismo. De esta manera, no definí a la música por lo musicológicamente observable, como si los términos de la apreciación estética se derivaran de la música en sí misma y fueran independientes del resto de los elementos de la configuración a estudiar. Tampoco 
interpreté el sello y su profesionalización desde un juego social de la identidad o la distinción, como si el vínculo con la música se agotara en la creencia o, de acuerdo a las versiones beckerianas de este argumento, en un trabajo. Por el contrario, a partir de una etnografía que encontró su especificidad en una historia de las mediaciones hecha en diálogo con los actores, intenté hacer emerger el objeto musical en la multiplicidad de instancias en la que mis interlocutores se involucraban con música.

De esta manera, la interpretación de la música no se resolvió desde una teoría del sentido exterior a las prácticas. Al seguir a quienes se convirtieron en mis interlocutores, pude acceder al significado del arte y la música para ellos. La música era una oportunidad de trabajo, una opción de disfrute, un motivo para hacerse amigos y comprometerse con ellos, un entorno para habitar con otras artes, una competencia profesional, un relato no meramente estético, una disputa por lo nuevo y una perspectiva de futuro. Como me dijo uno de ellos, quizás sin sospechar hasta dónde haría llegar sus palabras, lo que definía su vínculo con la música era estar en ella. Que el sentido de la música remitiera a una actividad, y más precisamente a un verbo, indicaba hasta qué punto estas prácticas musicales huían de la vocación codificadora y totalizante de la sociología.

Hasta aquí he realizado una serie de observaciones de cierre al respecto de los hallazgos empíricos, su diálogo con el estado actual de los estudios sociales de la música y la forma en que la investigación implicó una forma específica de practicar la etnografía, a partir del diálogo con los protagonistas de la configuración musical estudiada, la tradición etnográfica y las orientaciones derivadas de una sociología de las mediaciones. Quisiera ahora realizar una última consideración acerca de la inscripción de esta tesis al interior de la sociología de la cultura. Tradicionalmente, esta disciplina entendió la cultura como un ámbito específico de la vida social, ya sea por la delimitación de una actividad -la educación, el arte y, en general, las manifestaciones expresivas- o por referencia a la esfera de los valores, en una continuidad con la propuesta parsoniana generalmente poco reconocida. Estas dos vías suelen conducir al legitimismo porque parten de lo evidente, de lo dado, y no del camino que lo produce. En este contexto, los estudios de la música suelen abordar su objeto a partir de teorías de la cultura que han olvidado que los objetos estéticos, como todas las cosas del mundo, tienen que hacerse. Por mi parte, estudié esta música 
acompañando a unos actores que buscaban una teoría propia, la que hablara de su estar en la música. 


\section{Referencias bibliográficas}

Alabarces, P., Salerno, D., Silba, M. y Spataro, C. (2008). "Música popular y resistencia: los significados del rock y la cumbia”, en Alabarces, P. y Rodríguez, M. G. (comps.). Resistencias y Mediaciones. Estudios sobre cultura popular. Buenos Aires: Paidós. Alonso, L. E. (1998). La mirada cualitativa en sociología. Madrid: Fundamentos. Álvarez, J. (2013). Memorias. Buenos Aires: Libros del Zorzal.

Bayardo, R. (2005). Políticas culturales y cultura política. Notas a las Conversaciones. Argumentos, 5, 1-5.

Becker, H. (2008). Los mundos del arte. Sociología del trabajo artístico. Buenos Aires: Universidad Nacional de Quilmes Editorial.

Becker, H. (2009). Outsiders. Hacia una sociología de la desviación. Buenos Aires, Siglo XXI.

Benedetti, M. C. (2008). El rock de los desangelados. Música, sectores populares y procesos de consumo. TRANS-Revista Transcultural de Música, 12.

Benzecry, C. (2012). El fanático de la ópera. Etnografia de una obsesión. Buenos Aires: Siglo XXI Editores.

Blázquez, G. (2008). Nosotros, Vosotros y Ellos. Las poéticas de las masculinidades heterosexuales entre jóvenes cordobeses. TRANS-Revista Transcultural de Música, 12.

Blázquez G. (2009). Músicos, mujeres y algo para tomar. El mundo de los cuartetos de Córdoba. Ciudad de Córdoba: Ediciones Recovecos.

Blázquez G. (2011). Entrevista realizada por Pablo Semán. Revista Argentina de Estudios de Juventud, 1(4).

Blázquez, G. (2012). “I Love the Nightlife”. Músicas, imágenes y mundos culturales juveniles en Argentina. TRANS-Revista Transcultural de Música, 16, 1-26.

Boix, O. (2011). 'Yo toco la guitarra como soy': una aproximación etnográfica a la escena indie platense. Tesina de Licenciatura inédita. Licenciatura en Sociología. Facultad de Humanidades y Ciencias de la Educación, Universiad Nacional de La Plata. 
Boix, O. (2013). Sellos emergentes en La Plata: nuevas configuraciones de los mundos de la música. Tesis de Maestría, Maestría en Ciencias Sociales. Facultad de Humanidades y Ciencias de la Educación, Universidad Nacional de La Plata.

Boltanski, L. y Chiapello, E. (2002). El nuevo espíritu del capitalismo. Madrid: Akal.

Borges, A. (2011). Mujeres y sus casas: retrospectiva y perspectiva de un sendero en antropología y sociología. Revista Estudios Sociológicos del Colegio de México, 29 (87), 981-1000.

Bourdieu, P. (2000). La disolución del campo religioso. En: Bourdieu, P., Cosas Dichas. Barcelona: Gedisa.

Bourdieu, P. (2006). Génesis y Estructura del campo religioso. Revista Relaciones, 27 (108), 29-83.

Bourdieu, P. (2010). El sentido social del gusto. Elementos para una sociología de la cultura. Buenos Aires: Siglo XXI.

Bourdieu, P. (1983). Campo de poder y campo intelectual. Buenos aires: Folios.

Callon, M. (1986). Éléments pour une sociologie de la traduction. La domestication des coquilles Saint-Jacques et des marins-pêcheurs dans la baie de Saint-Brieuc. L'Année sociologique (1940/1948), (36), 169-208.

Carozzi, M. J. (2009). Una ignorancia sagrada: aprendiendo a no saber bailar tango en Buenos Aires. Religião e Sociedade, 29(1), 126-145.

Carozzi, M. J. (2011). Ni tan pasionales ni tan decentes: tras las huellas de la liviandad en las clases de tango milonguero y las milongas céntricas porteñas. En: Carozzi, M. J. (comp.), Las palabras y los pasos. Etnografías de la danza en la ciudad. Buenos Aires: Gorla- Ediciones EPC

Cingolani, J. (2013). Rock post-Cromañón. La reconfiguración del circuito de rock platense. En: Actas de I Jornadas Interdisciplinarias de Jóvenes Investigadores en Ciencias Sociales. Instituto de Altos Estudios, Universidad Nacional de San Martín, San Martín, Buenos Aires.

Cingolani, J. (2015). Esa ciudad alterna existe y la queremos mostrar. Pensar el vínculo entre rock y territorio a partir de un evento de cultura rock en la ciudad de La Plata. Actas de XI Jornadas de Sociología. Facultad de Ciencias Sociales, Universidad de Buenos Aires, Buenos Aires. 
Clifford, J. (1999). Itinerarios transculturales. Barcelona: Gedisa.

Collado, P. (2010). Cruces entre la cultura de masas y la radicalización política en el giro contracultural del rock argentino. Tesis de Licenciatura en Historia. Facultad de Humanidades y Ciencias de la Educación, UNLP.

Corti, B. (2007). Las redes del disco independiente: apuntes sobre producción, circulación y consumo. En: VV.AA., Las Industrias Culturales en la Ciudad de Buenos Aires. Buenos Aires: Observatorio de Industrias Culturales de la Ciudad de Buenos Aires, Gobierno de la Ciudad de Buenos Aires.

Corti, B. (2009). Redefiniciones culturales en la Buenos Aires post Cromañón. El debate sobre el vivo de la música independiente. En: Actas de VIII Reunión de Antropología del Mercosur. Buenos Aires.

Cragnolini, A. (2006). Articulaciones entre violencia social, significante sonoro y subjetividad: la cumbia 'villera' en Buenos Aires. TRANS-Revista Transcultural de Música, 10.

Dale, P. (2009). It was easy, it was cheap, so what?: Reconsidering the DIY principle of punk and indie music. Popular Music History, 3, 171-193.

De Certeau, M. (2008). La invención de lo cotidiano 1. Artes de hacer. México D.F: Universidad Iberoamericana,

Del Águila, M. (2015). Las formas de la música hoy. Los alcances de lo digital con la intensidad de lo real. En: Mena, M. y Maccari, B. (coords.) Guía REC. Claves y herramientas para descifrar el ecosistema actual de la música. Buenos Aires: Ministerio de Cultura de la Nación.

Del Mármol, M. Magri, G. y Sáez, M. (2014). Acerca de "lo independiente" en las artes escénicas platenses: Un abordaje etnográfico. Actas de VIII Jornadas de Sociología de la UNLP. Facultad de Humanidades y Ciencias de la Educación, Universidad Nacional de La Plata, La Plata

DeNora, T. (2000). Music in everyday life. Nueva York: Cambridge University Press.

DeNora, T. (2012). La música en acción: constitución del género en la escena concertística de Viena, 1790-1810. En: Benzecry, C. Hacia una nueva sociología cultural. Buenos Aires: Universidad Nacional de Quilmes Editorial. 
De Singly, F. (2006). La sociología, forma particular de conciencia. En: Lahire, B. ¿Para qué sirve la sociología? Buenos Aires: Siglo XXI.

Di Cione, L. (2009). ¿Un alquimista del éxito? El proceso de consolidación del productor artístico como figura clave del rock en Argentina. Revista Argentina de Musicología, 10, 165-181.

Díaz, C. (2005). Libro de viajes y extravios: un recorrido por el rock argentino (19651985). Unquillo: Narvaja Editor.

Doeswijk, M. y Ruiz, F. D. (2007). El rock platense de los años 90. Tesis de Producción en Comunicación Social. Facultad de Periodismo y Comunicación Social, Universidad Nacional de La Plata.

Elbaum, J. (1994): Los bailanteros. La fiesta urbana de la cultura popular. En: Margulis, M. et. al. La cultura de la noche. La vida nocturna de los jóvenes en Buenos Aires. Buenos Aires: Espasa Hoy.

Faulkner, R. y Becker, H. (2011). El jazz en acción. La dinámica de los músicos sobre el escenario. Buenos Aires: Siglo XXI.

Ferraudi Curto, M. C. (2014). Ni punteros ni piqueteros. Urbanización y política en una villa del conurbano. Buenos Aires: Editorial Gorla.

Fernández, J. L. (2012). Los Mimilocos. Jóvenes lanzallamas. En: Flores, D. (comp.) Gente que no. Postpunks, darks y otros iconoclastas del under porteño en los 80. Buenos Aires: Piloto de Tormenta.

Fouce, H. (2010). De la crisis del mercado discográfico a las nuevas prácticas de escucha. Comunicar. Revista científica iberoamericana de comunicación y educación, (34), 65-72.

Fouce, H. (2012). Entusiastas, enérgicos y conectados en el mundo musical. En: García Canclini, N.; Urteaga Castro Pozo, M., y Cruces, F. (Coords.), Jóvenes, culturas urbanas y redes digitales. Madrid: Ariel y Fundación Telefónica.

Frith, S. (2003). Música e identidad. En: Hall S. y Du Gay, P. (comps.). Cuestiones de identidad cultural. Buenos Aires: Amorrortu.

Frith, S. (2006). La industria de la música popular. En: Frith, S., Straw, W. y Street, J. (comps.). La otra historia del rock. Barcelona: Manontroppo. 
Gallo, G. (2011). In Coco We Trust. Club, casa y proyecto: experiencias y producción musical electrónica en un local de Buenos Aires. Tesis de maestría en Antropología Social. Facultad Latinoamericana de Ciencias Sociales.

Gallo, G. (2011b), Poder bailar lo que me pinta: movimientos libres, posibles y observados en pistas de baile electrónicas. En: Carozzi, M.J. (comp.). Las palabras y los pasos. Buenos Aires: Editorial Gorla- Ediciones EPC

Gallo, G. (2015). El más rockero de los djs. Iniciaciones en el mundo musical electrónico porteño. Apuntes de Investigación del CECYP, 27 (25), 175-194.

Gallo, G. y Semán, P. (2012). Música y nuevas tecnologías: efectos de pluralización. Revista Versión. Estudios de Comunicación y Política, (35), 151-162.

García Canclini, N. (2012). Introducción. De la cultura postindustrial a las estrategias de los jóvenes. En: García Canclini, N.; Urteaga Castro Pozo, M., y Cruces, F. (Coords.), Jóvenes, culturas urbanas y redes digitales. Madrid: Ariel y Fundación Telefónica.

García Canclini, N. (2012). De la carrera a los proyectos. En: García Canclini, N.; Urteaga Castro Pozo, M., y Cruces, F. (Coords.), Jóvenes, culturas urbanas y redes digitales. Madrid: Ariel y Fundación Telefónica.

García Canclini, N. y Cruces, F. (2012). Conversación a modo de prólogo. En: García Canclini, N.; Urteaga Castro Pozo, M., y Cruces, F. (Coords.), Jóvenes, culturas urbanas y redes digitales. Madrid: Ariel y Fundación Telefónica.

Garriga Zucal, J. (2008). Ni “chetos”, ni "negros": roqueros. TRANS-Revista Transcultural de Música, 12.

Gerber Bicecci, V. y Pinochet Cobos, C. (2012). La era de la colaboración. Mapa abreviado de nuevas estrategias artísticas. En: García Canclini, N.; Urteaga Castro Pozo, M., y Cruces, F. (Coords.), Jóvenes, culturas urbanas y redes digitales. Madrid: Ariel y Fundación Telefónica.

Moreira, V. (2006). Una mujer en campo masculino y la identificación de género en el proceso de producción del conocimiento antropológico. Actas del VII Seminario Internacional Haciendo Género, Florianópolis, Brasil.

Graziano, M.

Grignon, C. y Passeron, J. C. (1991). Lo culto y lo popular. Miserabilismo y populismo en sociología y literatura. Buenos Aires: Nueva Visión. 
Hall, S. y Jefferson, T. (2010). Una vez más: Resistencia a través de rituales. En: Hall, S. y Jefferson, T. (comps.), Resistencia a través de rituales. Subculturas juveniles en la Gran Bretaña de posguerra. La Plata: Observatorio de Jóvenes. Comunicación y Cultura, Facultad de Periodismo y Comunicación Social, Universidad Nacional de La Plata.

Hebdige, D. (2002). Subcultura. El significado del estilo. Barcelona: Paidós.

Hennion, A. (1989). An Intermediary between Production and Consumption; the Producer of Popular Music. Science, Technology and Human Values, 4 (14): 400-424

Hennion, A. (2002). La pasión musical. Barcelona: Paidós.

Hennion, A. (2010). Gustos musicales: de una sociología de la mediación a una pragmática del gusto. Comunicar, 17 (34): 25-33.

Hennion, A. (2012). Melómanos: el gusto como performance. En: Benzecry, C. (comp). Hacia una nueva sociología cultural. Buenos Aires: Universidad Nacional de Quilmes Editorial.

Hesmondhalgh, D. (2015). Por qué es importante la música. Buenos Aires: Paidós.

Hine, C. (2012). The Internet: Understanding Qualitative Research. Nueva York: Oxford University Press.

Igarzábal, N. (2015). Cemento, el semillero del rock (1985-2004). Buenos Aires: Editorial Gourmet Musical.

Infantino, J. (2011). Trabajar como artista. Estrategias, prácticas y representaciones del trabajo artístico entre jóvenes artistas circenses. Cuadernos de Antropología Social, 34, 141-163.

Irisarri, V. (2011). 'Por Amor al Baile'. Música, tecnologías digitales y modos de profesionalización en un grupo de DJs-productores de Buenos Aires. Tesis de Maestría inédita. Maestría en Antropología Social. IDES-Universidad Nacional de San Martín.

Irisarri, V. (2015). Fora do Eixo, dentro do mundo. Política, mercado e vida cotidiana em um movimento brasileiro de produção cultural. Tesis de Doctorado en Antropología Social. Universidade Federal do Rio Grande do Sul, Brasil.

Jalil, O. (2000). Rock versión tinta. Antología del rock platense de los '90. La Plata: La comuna ediciones.

Keightley, K. (2006). Reconsiderar el rock. En: Frith, S.; Straw, W. y Street, J. (comps.), La otra historia del rock. Barcelona: Ma Non Troppo. 
Lamacchia, M. C. (2012). Otro cantar. La música independiente en Argentina. Buenos Aires: Unísono Ediciones.

Latour, B. (2008). Reensamblar lo social: una introducción a la teoría del actor red. Buenos Aires: Manantial.

Lee, J. (2015). Open mic: La profesionalización de la carrera rapera. Apuntes de investigación del CECYP, 15 (25), 93-116.

López, M. D. (2013). Producción cultural, “elites culturales” y espacios de exhibición. Una aproximación a las experiencias en la ciudad de La Plata. En: Actas de I Jornadas Interdisciplinarias de Jóvenes Investigadores en Ciencias Sociales. Instituto de Altos Estudios Sociales, Universidad Nacional de San Martín. San Martín, Buenos Aires.

López, V. S. (2012). Reflexión sobre la aplicabilidad de los conceptos "subcultura" y "contracultura", elaborados por el Centro de Estudios Culturales de Birmingham, en el estudio del underground porteño de los 80. En: Actas de ALAIC XI Congreso Latinoamericano de Investigadores en Comunicación.

López Cano, R. (2011). Juicios de valor y trabajo estético en el estudio de las músicas populares urbanas de América Latina. En: Sans, J. F. y López Cano, R. (coords.), Música popular y juicios de valor: una reflexión desde América Latina. Caracas: Centro de Estudios Latinoamericanos Rómulo Gallego.

Luchetti, K. (2007). Estructuración de la producción y organización empresaria en la industria fonográfica. El surgimiento de asociaciones de productores fonográficos 'independientes'. Tesina de licencitatura inédita. Licenciatura en Ciencias de la Comunicación. Facultad de Ciencias Sociales, Universidad de Buenos Aires.

Luker, M. (2010). The Managers, the Managed, and the Unmanageable: Negotiating Values at the Buenos Aires International Music Fair. Ethnomusicology Forum, 19(1), 89-113.

Lunardelli, L. (2002). Alternatividad, divino Tesoro. El rock argentino en los 90. Buenos Aires: Biblos.

Madoery, D. (2010). El folklore profesional. Una perspectiva que aborda las continuidades. Actas del IX Congreso de la Rama Latinoamericana de IASPM. Escuela Universitaria de Música. Caracas. 
Madoery, N. (2015). Nociones y herramientas de marketing digital. En: Mena, M. y Maccari, B. (coords.) Guia REC. Claves y herramientas para descifrar el ecosistema actual de la música. Buenos Aires: Ministerio de Cultura de la Nación.

Marradi, A., Archenti, N. y Piovani, J. (2012). Metodología de las Ciencias Sociales. Buenos Aires: Cengage Learning.

Martín, E. (2008). La cumbia villera y el fin de la cultura del trabajo en la Argentina de los 90. TRANS- Revista Transcultural de Música, 12.

Mc Robbie, A. (2002). Clubs to Companies: Notes on the Decline of Political Culture in Speeded Up Creative Worlds. Cultural Studies, 16(4), 516-531.

Mc Robbie, A. (2007). La 'losangelización' de Londres: tres breves olas de microeconomía juvenil de la cultura y la creatividad en Gran Bretaña. En: http://eipcp.net/transversal/0207/mcrobbie/es (consultado: 29/08/2012).

Menger, P. M. (2002). Portrait de l'artiste en travailler. Métamorphose du capitalisme. Paris: Editions du Seuil/La Republique des Idées.

Miguel, P. (2012). La pregunta por la creatividad. Notas sobre el análisis de la producción reciente en las industrias creativas argentinas. Cuadernos de Filosofía Latinoamericana, (33), 106, 113-129.

Miguel, P. (2013). Emprendedores del diseño. Apuntes para una sociología de la moda. Eudeba: Buenos Aires.

Míguez, D. (2006). Estilos musicales y estamentos sociales. Cumbia, villa y transgresión en la periferia de Buenos Aires, en Míguez, D. y Semán, P. (eds.), Entre santos, cumbias y piquetes: las culturas populares en la Argentina reciente. Buenos Aires: Biblos.

Mihal, I. y Quiña, G. (2015). Notas sobre la relación entre independencia y cultura. Los casos discográfico y editorial en la ciudad de Buenos Aires en clave comparativa. Iberoamericana, 15 (58), 139-158

Nardacchione, G. (2011). El conocimiento científico y el saber práctico en la sociología pragmática francesa. Reflexiones sobre la sociología de la ciencia de Bruno Latour y la sociología política de Luc Boltanski. Apuntes de Investigación del CECYP, 14 (19), 171182. 
Navarro, G. (2015). Derechos de autor y propiedad intelectual. En: Mena, M. y Maccari, B. (coords.) Guía REC. Claves y herramientas para descifrar el ecosistema actual de la música. Buenos Aires: Ministerio de Cultura de la Nación.

Negus, K. (2005). Los géneros musicales y la cultura de las multinacionales. Buenos Aires: Paidós.

Ochoa, A. M. (2003). Músicas locales en tiempos de globalización. Buenos Aires: Norma. Palmeiro, C. (2005). La Industria Del Disco. Economía de las PyMEs de la Industria discográfica en la ciudad de Buenos Aires. Buenos Aires: Investigaciones OIC, Secretaria de Cultura del Gobierno de la ciudad de Buenos Aires.

Pais, J. M. y Mendes de Almeida, M. I. (2012). Criatividade, juventude e novos horizontes profissionais. Rio de Janeiro: Zahar.

Peirano, M. (1995). A favor da etnografia. Rio de Janeiro: Relúme-Dumará.

Peña Boerio, V. (2011). Prácticas de distinción y consumo cultural de las clases medias: el caso de la música indie. Actas de X Congreso Argentino de Antropología Social, Universidad de Buenos Aires, Buenos Aires.

Pinochet Cobos, C. (2015). De la economía creativa a la escala etnográfica. Apuntes en torno al trabajo artístico joven. Revista Ensambles, 1(2), 66-79.

Pujol, S. (2007). Rock y dictadura. Crónica de una generación. Buenos Aires: Booket.

Pujol, S. (2013). Cien años de música argentina. Buenos Aires: Biblos.

Quiña, G. (2009a). Consumos culturales y libertad creativa. El rol del productor artístico en la escena musical independiente. En: Actas de XXVII Congreso ALAS. Buenos Aires.

Quiña, G. (2009b). ¿Amor a la música o pequeña industria cultural? Las múltiples dimensiones de la 'escena musical independiente' en el área metropolitana de Buenos Aires. En: Actas de VIII Reunión de Antropología del Mercosur, Buenos Aires.

Quiña, G. (2012). Entre la libre creación y la industria cultural. La producción musical independiente en la Ciudad de Buenos Aires desde 1999 a la actualidad. Tesis de Doctorado. Doctorado en Ciencias Sociales. Facultad de Ciencias Sociales, Universidad de Buenos Aires.

Recalculando (2015). Sellos de gestión colectiva. En: Mena, M. y Maccari, B. (coords.) Guía REC. Claves y herramientas para descifrar el ecosistema actual de la música. Buenos Aires: Ministerio de Cultura de la Nación. 
Reynolds, S. (2009). ¿Se terminó el underground? En: Reynolds, S. (2010). Después del rock. Psicodelia, post-punk, electrónica y otras revoluciones inconclusas. Buenos Aires: Caja Negra.

Reynolds, S. (2012). Retromanía. La adicción del pop a su propio pasado. Buenos Aires: Caja Negra.

Rodríguez Alzueta, E. (2005). Entre la elegancia del pop y el rock chabón. Blog Crudos. Ensayos, tribulaciones y bocetos. Octubre de 2005. www.rodriguezesteban.blogspot.com Consultado: 04/12/2008.

Sainz, A. (2012). La sobrecarga. Donde nada pasa. En: Flores, D. (comp.) Gente que no. Postpunks, darks y otros iconoclastas del under porteño en los 80. Buenos Aires: Piloto de Tormenta.

Salerno, D. y Silba, M. (2006). Juventud, identidad y experiencia: las construcciones identitarias populares urbanas. Revista Question, 10.

Segura, R. (2015). Vivir afuera. Antropología de la experiencia urbana. San Martín: UNSAM Edita.

Semán, P. (2006). El pentecostalismo y el rock chabón en la transformación de la cultura popular. En: Míguez, D y Semán, P. (eds). Entre santos, cumbias y piquetes: las culturas populares en la Argentina reciente. Buenos Aires: Biblos.

Semán, P. (2011). Editorial. Revista Argentina de Estudios de Juventud, (4), s/p.

Semán, P. (2015). La puesta en cuestión de la representación romántica del arte. Revista Ensambles, 1(2), 9-10.

Semán, P. y Vila, P. (1999). Rock chabón e identidad juvenil en la Argentina neo-liberal". En: Filmus, D. Los 90. Política, sociedad y cultura en América Latina y Argentina en fin de siglo. Buenos Aires: Eudeba.

Semán, P. y Vila, P. (2008). La música y los jóvenes de los sectores populares: más allá de las 'tribus'. Revista Transcultural de Música, 12.

Semán, P. y Vila, P. (2011). Introducción. En: Semán, P. y Vila, P. (comps.). Cumbia, nación, etnia y género en Latinoamérica. Buenos Aires: Editorial Gorla-Ediciones EPC. Shuker, R. (2005), Diccionario del rock y la música popular, Barcelona: Ma non troppo. 
Silba, M. y Spataro, C. (2008): Cumbia nena. Letras, relatos y bailes según las bailanteras. En: Alabarces, P. y Rodríguez, M. G. (comps.), Resistencias y Mediaciones. Estudios sobre cultura popular. Buenos Aires: Paidós.

Spataro, C. (2012). Señora de las cuatro décadas: un estudio sobre el vínculo entre música, mujeres y edad. Revista da Associação Nacional dos Programas de Pós-Graduação em Comunicação, 15 (2), 1-16.

Svampa, M. (2005). La sociedad excluyente. La Argentina bajo el signo del neoliberalismo. Buenos Aires: Taurus.

Szpilbarg, D. (2010). Editoriales artesanales y libros-arte: nuevos modos de producción y circulación social del libro. Reflexiones a partir del caso de las editoriales Funesiana y Clase Turista. En: Actas de VI Jornadas de Sociología de la UNLP. Facultad de Humanidades y Ciencias de la Educación, Universidad Nacional de La Plata, La Plata.

Théberge, P. (2006). Conectados: la tecnología y la música popular. En: Frith, S., Straw, W. y Street, J. (comps.). La otra historia del rock. Barcelona: Manontroppo.

Tironi, M. (2012). Para una sociología pragmática del gusto. Antoine Hennion en entrevista. En: Ossandon J., Vodanovic L. (ed.). Disturbios Culturales. Santiago de Chile: Ediciones Universidad Diego Portales.

Trànsit Projectes (2012). Música para Camaleones. El black álbum de la sostenibilidad cultural. Barcelona.

Vanoli, H. (2009). Pequeñas editoriales y transformaciones en la cultura literaria argentina. Apuntes de Investigación del CECYP, (15), 161-185.

Vecino, D. (2011). Nuevos sellos discográficos y la producción de música independiente en la ciudad de Buenos Aires, 1998-2010. En: Rubinich, L. y Miguel, P. (comps.), 0110. Creatividad, economía y cultura en la ciudad de Buenos Aires. Buenos Aires: Aurelia Rivera.

Velho, O. (2015). Qué es pensar desde el sur. En: XI Reunión de Antropología del Mercosur. Mimeo.

Vicentini, L. (2010). Cultura, rock y jóvenes en La Plata. En: Gutiérrez, E. (ed.), Rock del país: estudios culturales de rock en Argentina. San Salvador de Jujuy: Universidad Nacional de Jujuy. Universitaria de Jujuy. Facultad de Humanidades y Ciencias Sociales. 
Vila, P. (1985). Rock nacional: crónicas de la resistencia juvenil. En Jelin, E. (comp.), Los nuevos movimientos sociales: mujeres, rock nacional. Buenos Aires: Centro Editor de América Latina.

Vila, P. (1987a). Tango, folklore y rock: apuntes sobre música, política y sociedad en Argentina. Cahiers du monde Hispanique et Luso-Brésilien.

Vila, P. (1987b). El rock. Música argentina contemporánea. Punto de Vista, 30, 23-29.

Vila P. (1989), Argentina's 'Rock Nacional': The Struggle for Meaning. Latin American Music Review / Revista de Música Latinoamericana, 10 (1), 1-28.

Vila, P. (1996). Identidades narrativas y música. Una primera propuesta para entender sus relaciones". TRANS-Revista Transcultural de Música, 2.

Weber, S. y Mitchell, C. (2008). Imaginar, Mecanografiar y Nuevas Tecnologías. En: Buckingham D. (ed.), Juventud, Identidad y Medios Digitales. Cambridge, MA: MIT Press. Willis, P. (1978). Profane culture. Londres: Routledge \& Kegan Paul Books.

Woodside Woods, J.; Jiménez López, C. y Urteaga Castro Pozo, M. (2011). Creatividad y desarrollo: la música popular alternativa. En: García Canclini, N.; Urteaga Castro Pozo, M., y Cruces, F. (Coords.), Jóvenes, culturas urbanas y redes digitales. Madrid: Ariel y Fundación Telefónica.

Wright, S. (1998). La politización de la cultura. En: Boivin, M; Rosato, A y Arribas, V. (Coords.) Constructores de Otredad. Una introducción a la antropología social y cultural. Buenos Aires: Antropofagia.

Yúdice, G. (2002). El recurso de la cultura. Usos de la cultura en la era global. Barcelona: Gedisa.

Yúdice, G. (2007). Nuevas tecnologías, música y experiencia. Barcelona: Gedisa.

Yúdice (2008). La transformación y diversificación de la industria de la música. En: Bustamante, E. (ed.), La Cooperación cultura-Comunicación en Iberoamérica, Madrid, AECID

Zabiuk, M. (2009). Territorios del rock. Jóvenes universitarios y cambios culturales, 19601970. Los trabajos y los días. Revista de la cátedra de historia socioeconómica de América Latina y Argentina, 1, 69-87.

Ziegler, S. (2007). Los de excepción: un retrato de las elecciones escolares de las familias de sectores favorecidos en la Ciudad de Buenos Aires y el conurbano bonaerense. En: 
Narodowski, M. y Gómez Schettini, M. (comps.), Escuelas y familias. Problemas de diversidad cultural y justicia social. Buenos Aires: Prometeo. 